\title{
Uncovering hidden diversity: phylogeny and taxonomy of Physoderinae (Reduviidae, Heteroptera), with emphasis on Physoderes Westwood in the Oriental and Australasian regions
}

\author{
Wei Song HWANG ${ }^{1, *}$ \& Christiane WEIRAUCH ${ }^{2}$ \\ ${ }^{1}$ Lee Kong Chian Natural History Museum, Department of Biological Sciences, National University \\ of Singapore, 117377, Singapore. \\ 1,2 Department of Entomology, University of California, Riverside, Riverside, CA 92521, USA. \\ *Corresponding author: nhmhws@nus.edu.sg \\ ${ }^{2}$ Email: christiane.weirauch@ucr.edu \\ ${ }^{1}$ urn:1sid:zoobank.org:author:1899A130-C5D0-43F1-8299-069E425DC965 \\ ${ }^{2}$ urn:1sid:zoobank.org:author:59B6A54F-2044-4E5A-B7F7-AAC5E7D716F0
}

\begin{abstract}
The cryptic assassin bug subfamily Physoderinae is characterized by a distinctly uneven species and genus-level diversity across continents, but the lack of a phylogeny has so far precluded investigations into the biogeographic history of the group. Endemic Madagascan Physoderinae (11 of the 15 genera) exhibit broad morphological diversity, but the large (38 spp.) and seemingly uniform genus Physoderes is widely distributed across the Oriental and Australasian regions. The three remaining genera are small or even monotypic and restricted to the Neotropical (Cryptophysoderes, Leptophysoderes) and Afrotropical (Porcelloderes) regions. To investigate relationships among Physoderinae, with emphasis on the monophyly of the Madagascan fauna and the monophyly of Physoderes, we conducted a cladistic analysis based on 57 morphological characters and complete genus-level taxon sampling. We found that the Madagascan fauna is not monophyletic, indicating that the island was colonized more than once, although the great majority of Madagascan taxa are part of a single clade. Overall relationships are recovered as Afrotropical Porcelloderes + [(Neotropical Cryptophysoderes, Leptophysoderes $)+$ (Madagascan, Oriental and Australasian taxa)]. Physoderes is shown to be polyphyletic and 3 new genera, Breviphysoderes gen. nov., Macrophysoderes gen. nov. and Nanophysoderes gen. nov., are erected to accommodate new species and several species previously classified as Physoderes. A taxonomic revision of Physoderes and allied genera is conducted. Diagnoses, updated distribution ranges, habitus and genitalic images, and identification keys are provided. A total of 17 synonymies are given, and 15 new species and 3 new genera are described, focusing on the diversity of Physoderinae in the Oriental and Australasian regions. The new species are Breviphysoderes fulvopicta gen. et sp. nov., B. tenebrosa gen. et sp. nov., Macrophysoderes cirripilosa gen. et sp. nov., M. elongata gen. et sp. nov., M. finisterre gen. et sp. nov., M. grandis gen. et sp. nov., Paraphysoderes popeye sp. nov., Physoderes anamalaiensis sp. nov., $P$. brevipennis sp. nov., P. minime sp. nov., $P$. muluensis sp. nov., $P$. mysorensis sp. nov., $P$. nigripennis sp. nov., $P$. ractepilosa sp. nov. and $P$. tricolor sp. nov.
\end{abstract}

Keywords. Assassin bugs, systematics, diversification, radiation, Madagascar. 
Hwang W.S. \& Weirauch C. 2017. Uncovering hidden diversity: phylogeny and taxonomy of Physoderinae (Reduviidae, Heteroptera), with emphasis on Physoderes Westwood in the Oriental and Australasian regions. European Journal of Taxonomy 341: 1-118. https://doi.org/10.5852/ejt.2017.341

\section{Introduction}

The reduviid subfamily Physoderinae is among the lesser-known groups of assassin bugs due to cryptic habits, restriction of most species to apparently small endemic ranges in wet-tropical areas of the Old and New Worlds, and the overall small number of genera and species compared to other reduviid subfamilies (Rédei 2012; Weirauch et al. 2014): only 70 species classified into 15 genera are described to date (Maldonado 1990; Weirauch 2006; Davranoglou 2014; Davranoglou et al. 2015). All members are small, rarely collected, feature subtle hues of brown and dirty yellow that allow them to blend into leaf litter and decaying wood, and many species share a somewhat dorsoventrally flattened, compact body shape and relatively short, heavily armored legs (Fig. 1). In contrast, the physoderine fauna of Madagascar and the nearby Comoros Islands (11 genera with 29 spp.; Villiers 1962) shows considerable morphological diversity, with some taxa resembling assassin bugs in other subfamilies, such as Tribelocephaloides Villiers, 1962 and Mimoelasmodema Villiers, 1962, that superficially resemble Tribelocephalini (in the subfamily Ectrichodiinae) and Elasmodeminae, respectively (Villiers 1962; Weirauch et al. 2014; Forthman \& Weirauch 2017; Fig. 2). More speciose, but morphologically relatively uniform, the Oriental and Australasian fauna of Physoderinae comprises 38 species currently classified within a single genus - Physoderes Westwood, 1845 (Maldonado 1990; Cao et al. 2011; Chlond 2011). Only two Neotropical genera of Physoderinae have so far been described, the monotypic Cryptophysoderes Wygodzinsky \& Maldonado, 1972 from Panama and Leptophysoderes Weirauch, 2006 from Costa Rica and Ecuador, with L. sarapiqui Davranoglou, Hwang \& Weirauch, 2015 showing pronounced sexual dimorphism (Wygodzinsky \& Maldonado 1972; Weirauch 2006; Davranoglou et al. 2015). The only described continental Afrotropical species of Physoderinae is Porcelloderes impenetrabilis Rédei, 2012 from mountain ranges in northeastern Tanzania (Rédei 2012).

The present classification of Physoderinae is largely the result of the studies of two researchers: André Villiers and Norman C.E. Miller. Villiers (e.g., 1962, 1968) described the majority of the physoderine diversity in Madagascar during the 1950s and 1960s, and Miller (e.g., 1940, 1941) described the Oriental and Australasian Physoderes species in South-East Asia and the Pacific from the 1940s to the 1960s.
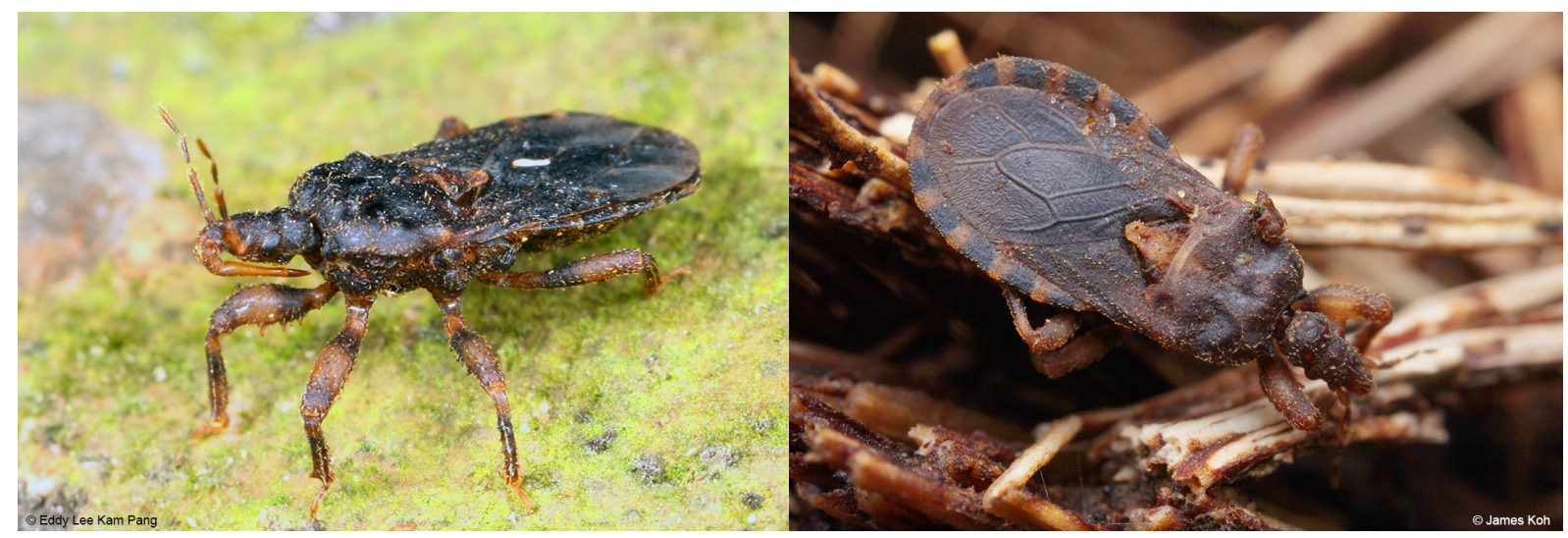

Fig. 1. In situ images of Physoderes curculionis China, 1936 in Singapore on mossy substrate (left) and vegetation debris (right). 
Since then, three Neotropical species (Wygodzinsky \& Maldonado 1972; Weirauch 2006; Davranoglou et al. 2015) were described as new and Physoderinae were rediagnosed by Weirauch (2006) and Rédei (2012). More recently, new species were described from Madagascar (Chlond 2011; Baňar̆ et al. 2016; Chlond et al. 2016), the Oriental (Cao et al. 2011) and Australasian regions (Davranoglou 2014), and Physoderes impexa (Distant, 1903) was redescribed (Cao et al. 2011).

Phylogenetic relationships of Physoderinae, both between genera and species within the group and to other clades of assassin bugs, have largely remained in the dark. Miller (1954) suspected that the Neotropical reduviine Aradomorpha Champion, 1899 may be closely related to Physoderinae, whereas Lent \& Wygodzinsky (1979) tentatively proposed a relationship with Triatominae, and Weirauch (2008) recovered the African reduviine Sphedanovarus Jeannel, 1866 as the sister taxon of the single species of Physoderes included in her morphology-based analysis. Molecular analyses found a poorly supported relationship with the Neotropical reduviine genus Leogorrus Stål, 1859 as part of an equally poorly supported larger clade also containing other Reduviinae and Salyavatinae (Weirauch \& Munro 2009). These hypotheses were either not based on cladistic analyses (Miller 1954; Lent \& Wygodzinsky 1979) or hampered by inadequate taxon sampling (Weirauch 2008; Weirauch \& Munro 2009). A recent molecular phylogenetic analysis with more comprehensive sampling of Reduviinae (but lacking Aradomorpha) found Physoderinae to be closely related to the Neotropical reduviine genera Microlestria Stål, 1872 and Nalata Stål, 1860 (Hwang \& Weirauch 2012). To date, relationships among genera and species of Physoderinae have not been investigated using cladistic methods: molecular data are available for less than a handful of species and morphological characters have not been coded and analyzed across the group. The Neotropical Leptophysoderes and Cryptophysoderes possess several characters thought to be plesiomorphic among Physoderinae and were suggested to be the putative sister-group of all remaining Physoderinae (Weirauch 2003), but this hypothesis remains to be tested. The aptery and resulting modified morphology somewhat hamper the testing of hypotheses for the phylogenetic placement of the Afrotropical Porcelloderes based on morphology. Finally, it also remains to be tested whether the Madagascan Physoderinae are monophyletic, representing a single clade and potentially therefore a radiation in adaptation to different habitats or other biotic or abiotic factors. Alternatively, the Madagascan fauna might represent several unrelated lineages, as recently shown for the assassin bug subfamily Ectrichodiinae (Forthman \& Weirauch 2016).

Even though some of the smaller genera are likely monophyletic, this is not necessarily the case for Physoderes: examination of specimens from various institutions, including types, has revealed undocumented morphological diversity that may challenge the monophyly of this genus. Physoderes currently contains 38 species mostly described by Miller (e.g., 1940, 1941), with additional species contributed by Westwood (1847), Stål (1863, 1870), Horváth (1900), Breddin (1903), Kirkaldy (1905), Bergroth (1906), Distant (1903, 1909), China (1935), Usinger (1946), Cao et al. (2011) and Davranoglou (2014). Physoderes has never been taxonomically revised, almost all descriptions lack proper diagnoses as well as high-quality habitus and genitalic illustrations, and no identification key for the genus is in existence, resulting in a large number of misidentified museum specimens. In addition, many species descriptions are based on singletons, with either males or females assigned as holotypes, which can be problematic due to the presence of sexual dimorphism in some species. A sizeable number of Physoderes specimens have accumulated in various museums (we have located 905 specimens in 13 natural history collections) and we believe that it is timely to produce a modern monograph of the Oriental/Australasian fauna of Physoderinae, while revising generic concepts across the group and recognizing monophyletic groups as genera.

Here we use a morphology-based cladistic analysis that includes representatives of all described physoderine genera, dense species-sampling of Physoderes and representatives of Microlestria, Nalata, 
and Aradomorpha as outgroups to: 1) investigate phylogenetic relationships within Physoderinae, with emphasis on the position of the Neotropical and Afrotropical genera as well as on the number and composition of monophyletic lineages in Madagascar; 2) test the monophyly of Physoderes; and 3) taxonomically revise the Oriental/Australasian fauna of Physoderinae according to the generic concepts derived from this analysis.

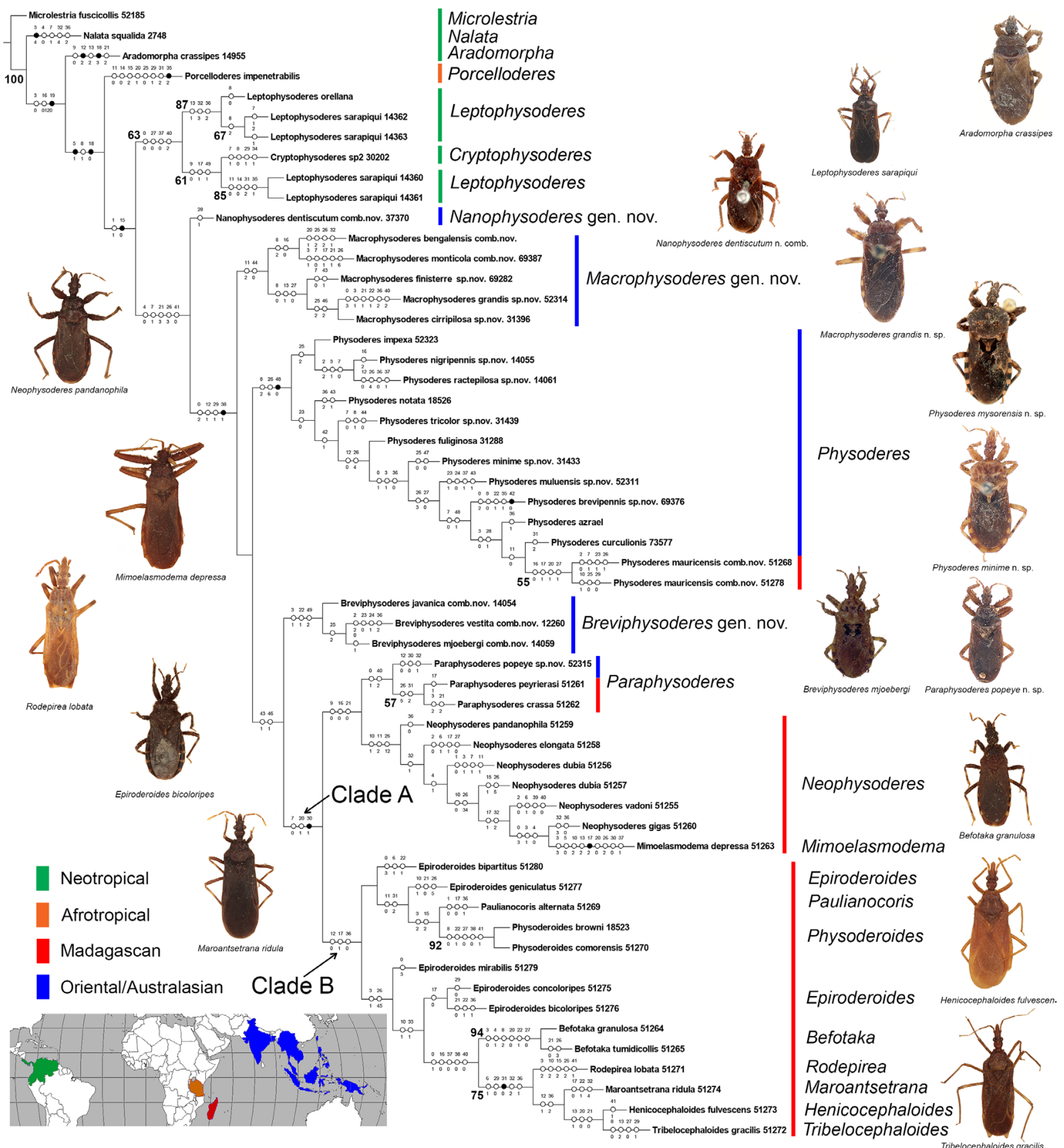

Fig. 2. Phylogeny of Physoderinae based on 57 morphological characters for 57 taxa analyzed using parsimony on TNT. Open white circles denote homoplastic characters, black circles denote characters that are not homoplastic. Numbers above the circles refer to character number (Table 1) and numbers below the circles refer to the character states (Table 3). Numbers in bold indicate symmetric resampling values. 


\section{Material and methods}

\section{Phylogenetic analysis}

\section{Taxon sampling}

A total of 57 taxa (3 outgroup taxa: Aradomorpha, Microlestria, Nalata; 54 ingroup taxa) were examined. All 14 genera of Physoderinae were sampled (Fig. 3), with all species represented except in Physoderes

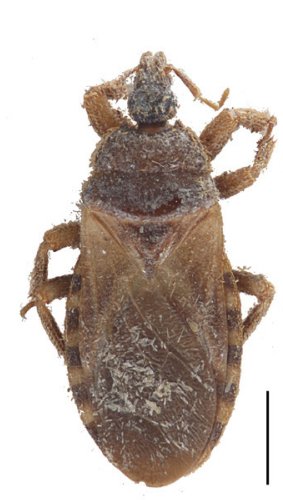

Aradomorpha crassipes UCR_ENT 000014955

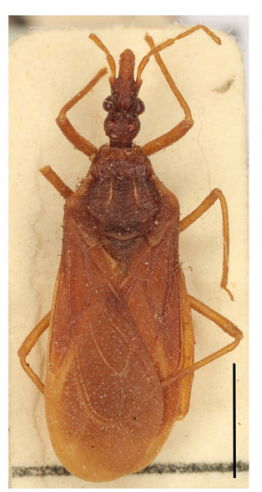

Henicocephaloides fulvescens Holotyp

UCR ENT 000051273

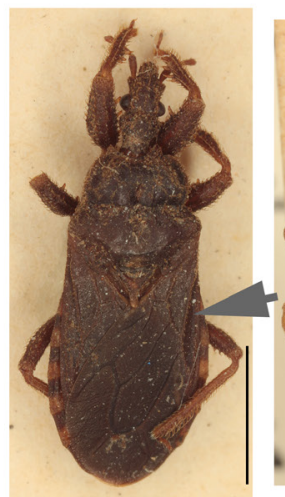

Paraphysoderes crassa Holotype

UCR_ENT 000051262
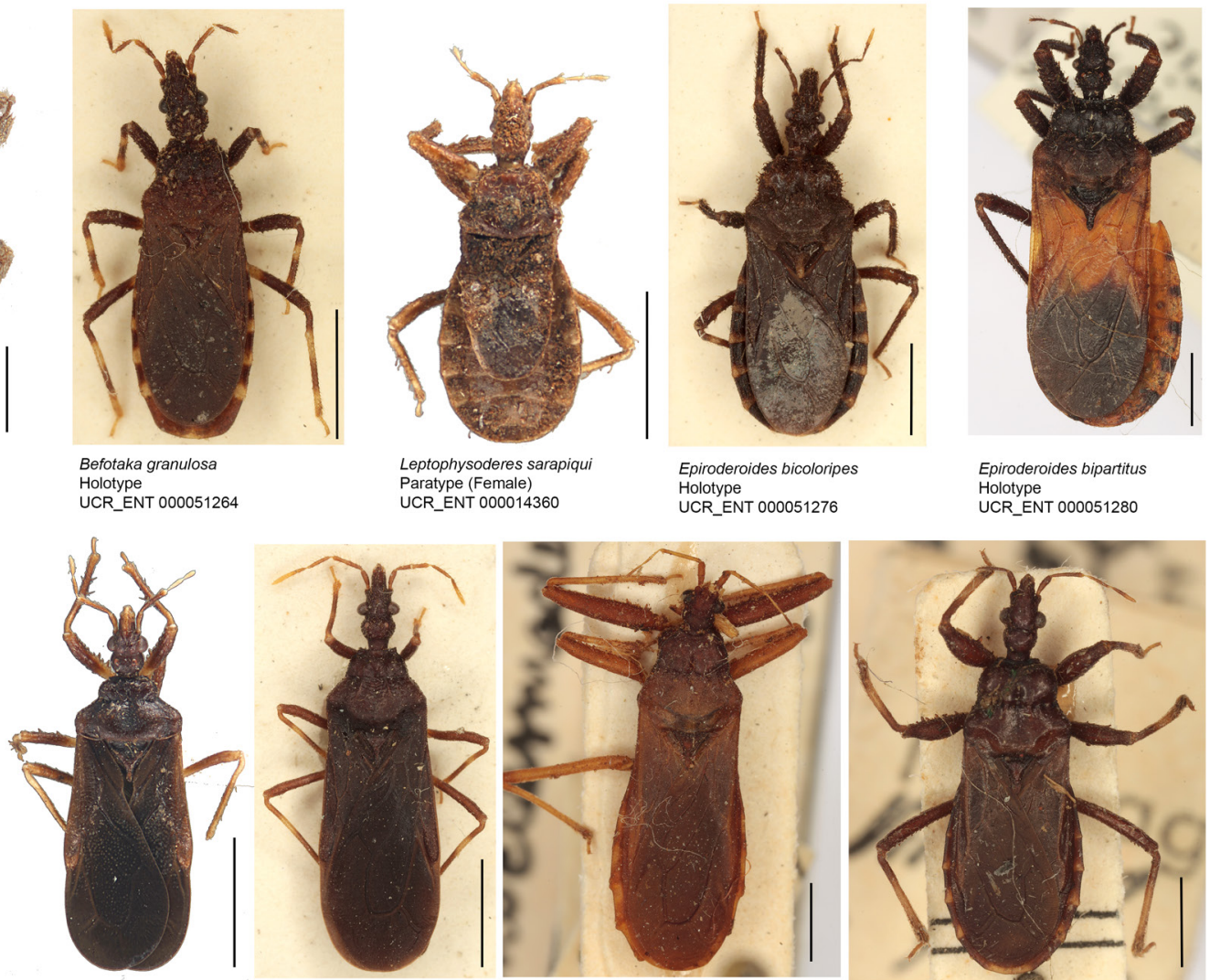

Leptophysoderes sarapiqui Holotype (Male)
UCR_ENT 000014363

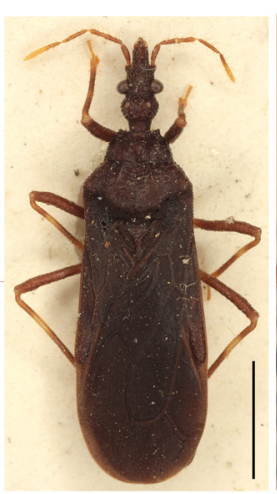

Maroantsetrana ridula Holotype
UCR ENT 000051274

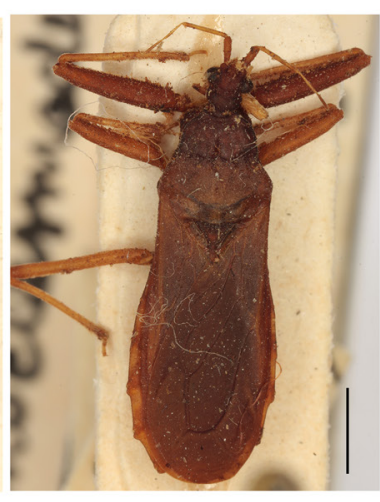

Mimoelasmodema depressa

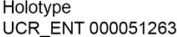

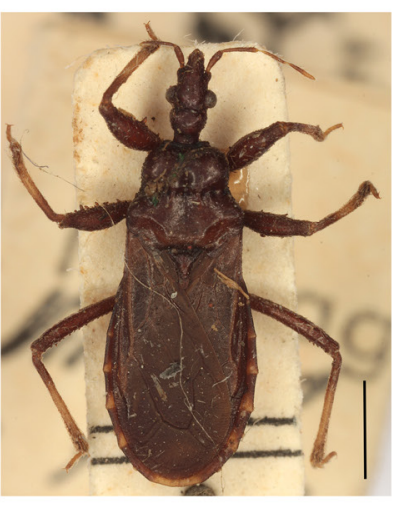

Neophysoderes pandanophil Uolotype
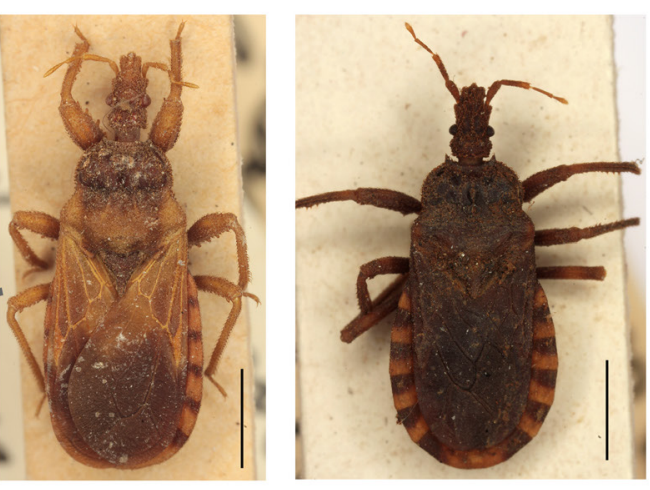

Physoderoides comorensis Holotype

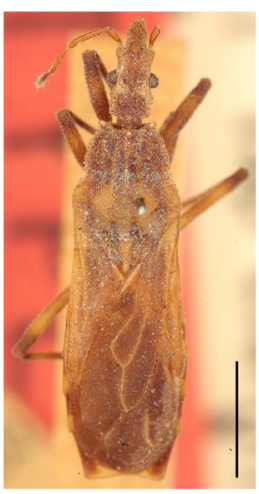

Rodepirea lobata Holotype
UCR ENT 000051271

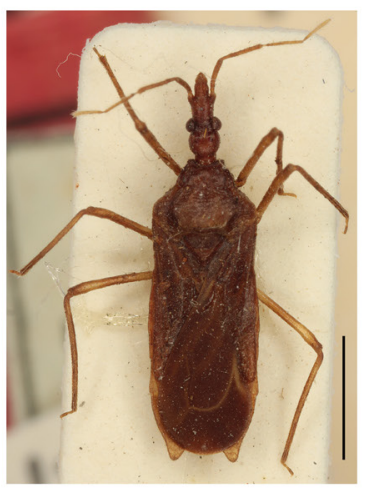

Tribelocephaloides gracilis Holotype

Fig. 3. Dorsal habitus images of other specimens examined for morphological coding. Images by JeanMichel Berenger, except Leptophysoderes sarapiqui Davranoglou, Hwang \& Weirauch, 2015 and Aradomorpha crassipes Champion, 1899. Scale bars $=2 \mathrm{~mm}$. 
Table 1. Morphological matrix for Physoderinae and outgroup taxa.

\begin{tabular}{|c|c|c|c|c|c|c|c|c|c|c|}
\hline & $\begin{array}{l}0 \\
0\end{array}$ & $\begin{array}{l}0 \\
5\end{array}$ & $\begin{array}{l}1 \\
0\end{array}$ & $\begin{array}{l}1 \\
5\end{array}$ & $\begin{array}{l}2 \\
0\end{array}$ & $\begin{array}{l}2 \\
5\end{array}$ & $\begin{array}{l}3 \\
0\end{array}$ & $\begin{array}{l}3 \\
5\end{array}$ & $\begin{array}{l}4 \\
0\end{array}$ & $\begin{array}{l}4 \\
5\end{array}$ \\
\hline scicollis_52185 & 01131 & 00001 & 01001 & 13121 & 01111 & 10010 & 01020 & 01201 & $10 ? ? ?$ & ????? \\
\hline Nalata_squalida_2748 & 10140 & 00101 & 01011 & 13011 & 00111 & 10100 & 01420 & 02201 & $11 ? ? ?$ & $? ? 210$ \\
\hline Aradomorpha_crassipes_14955 & 10101 & $0 ? 000$ & 01221 & 10130 & 02011 & 10100 & 01020 & 01201 & $11 ? 1 ?$ & $0 ? 0 ? ?$ \\
\hline Epiroderoides_mauricensis_51268 & 11000 & 10121 & 00001 & 00100 & $1301 ?$ & 11111 & 01020 & 00211 & $10 ? ? ?$ & $? ? ? ? ?$ \\
\hline Physoderes_mauricensis_51278 & 11100 & $1002 ?$ & 10001 & 00100 & 13002 & 03110 & 01020 & 00211 & $10 ? ? ?$ & $? ? ? ? ?$ \\
\hline Epiroderoides_concoloripes_51275 & 21110 & 10011 & 11001 & 01000 & 12010 & 15100 & 11110 & 00211 & $10 ? ? ?$ & $? ? ? ? ?$ \\
\hline Epiroderoides_bicoloripes_51276 & 21110 & 10011 & 11001 & 01000 & $1011 ?$ & 15101 & 11010 & 01211 & $10 ? ? ?$ & $? ? ? ? ?$ \\
\hline Epiroderoides_geniculatus_51277 & 21100 & 10011 & 10001 & 01100 & $1001 ?$ & $1510 ?$ & 12020 & 00211 & $10 ? ? ?$ & $? ? ? ? ?$ \\
\hline Epiroderoides_mirabilis_51279 & 31110 & 10011 & 01001 & 01100 & 13010 & 15101 & 11020 & 00211 & $10 ? ? ?$ & ????? \\
\hline Epiroderoides_bipartitus_51280 & 31100 & 11011 & 01001 & $01 ? 00$ & $1311 ?$ & 13101 & 11020 & 00211 & $10 ? ? ?$ & ???? \\
\hline Befotaka_granulosa_51264 & 11101 & 10021 & 11001 & 00100 & 02111 & 25001 & 11110 & 00001 & $00 ? ? ?$ & ???? \\
\hline Befotaka_tumidicollis_51265 & 11101 & 10021 & 11001 & 00100 & $0011 ?$ & 23001 & 11010 & 00001 & $00 ? ? ?$ & $? ? ? ? ?$ \\
\hline Neophysoderes_dubia_51256 & 20111 & 10100 & 11101 & 00000 & $1001 ?$ & 12101 & $11 ? ? ?$ & 01211 & $10 ? ? ?$ & $? ? ? ? ?$ \\
\hline Neophysoderes_dubia_51257 & 21101 & 10000 & 02101 & 10000 & $1001 ?$ & $2510 ?$ & 11101 & 01211 & $10 ? ? ?$ & $? ? ? ? ?$ \\
\hline Neophysoderes_vadoni_51255 & 21001 & 11000 & 02111 & 00100 & 10010 & $2410 ?$ & 11201 & 02210 & $00 ? ? ?$ & $? ? ? ? ?$ \\
\hline Neophysoderes_elongata_51258 & 21000 & 11000 & 12101 & 00100 & $1001 ?$ & 11001 & 11111 & 01211 & $10 ? ? ?$ & $? ? ? ? ?$ \\
\hline Neophysoderes_pandanophila_51259 & 21100 & 10000 & 12101 & 00000 & 10010 & 11101 & 11001 & 00211 & $10 ? ? ?$ & $? ? ? ? ?$ \\
\hline Neophysoderes_gigas_51260 & 31110 & 10000 & 02101 & 00100 & 10010 & 13101 & 11301 & 00211 & $10 ? ? ?$ & $? ? ? ? ?$ \\
\hline Henicocephaloides_fulvescens_51273 & 11110 & 11011 & 11111 & 00100 & 00010 & 14100 & 10210 & 02000 & $01 ? ? ?$ & $? ? ? ? ?$ \\
\hline Tribelocephaloides_gracilis_51272 & 11010 & 11001 & 11121 & 00100 & 00010 & 14001 & 10210 & $020 ? ?$ & $? 0 ? ? ?$ & $? ? ? ? ?$ \\
\hline Maroantsetrana_ridula_51274 & 11010 & 11011 & 11101 & 00000 & 12110 & 15100 & 10410 & 02000 & $00 ? ? ?$ & $? ? ? ? ?$ \\
\hline Mimoelasmodema_depressa_51263 & 31130 & 00000 & 22121 & 00200 & 00010 & 12101 & 01201 & 02111 & $10 ? ? ?$ & $? ? ? ? ?$ \\
\hline Paraphysoderes_peyrierasi_51261 & 11100 & 10000 & 01101 & 00100 & $1011 ?$ & $1510 ?$ & 12010 & 01211 & $20 ? ? ?$ & $? ? ? ? ?$ \\
\hline Paraphysoderes_crassa_51262 & 11120 & 10000 & 01101 & 00000 & 12010 & 15101 & $? 2010$ & 01211 & $20 ? ? ?$ & $? ? ? ? ?$ \\
\hline Paulianocoris_alternata_51269 & 20120 & 10011 & 00001 & 21000 & 12010 & 13101 & 12020 & 01211 & $10 ? ? ?$ & $? ? ? ? ?$ \\
\hline Physoderoides_browni_18523 & 21120 & 10001 & 00001 & 21100 & $1211 ?$ & $1300 ?$ & 12020 & 00201 & $11 ? ? ?$ & $? ? ? ? ?$ \\
\hline Physoderoides_comorensis_51270 & 21120 & 10001 & 00001 & 21100 & 12110 & 13001 & 12020 & 00201 & $11 ? ? ?$ & $? ? ? ? ?$ \\
\hline Rodepirea_lobata_51271 & 11120 & 11011 & 21001 & 20100 & 12010 & 22100 & 10210 & $010 ? ?$ & $? 1 ? ? ?$ & $? ? ? ? ?$ \\
\hline Porcelloderes_impenetrabilis & $1010 ?$ & $1001 ?$ & 00000 & 20000 & $1011-$ & $00-1$ & 02020 & $2-101$ & $11 ? ? ?$ & $? ? ? ? ?$ \\
\hline Leptophysoderes_sarapiqui_14360 & 01001 & 10010 & 00000 & 02100 & $0001 ?$ & 10000 & 02020 & $1-001$ & $21 ? 0 ?$ & $0 ? 011$ \\
\hline Leptophysoderes_sarapiqui_14361 & 01001 & 10010 & 00000 & 02100 & $0001 ?$ & $1000 ?$ & 02020 & $1-001$ & $21 ? 0 ?$ & $0 ? 011$ \\
\hline Cryptophysoderes_sp2_30202 & 01001 & 10100 & 01001 & 02100 & $0001 ?$ & 10001 & 01021 & 01001 & $21 ? 0 ?$ & $0 ? 011$ \\
\hline Leptophysoderes_orellana & $0100 ?$ & $1000 ?$ & 01011 & $0 ? 000$ & $? 0010$ & 10000 & 01320 & $0200 ?$ & $? 1 ?-1$ & $0 ? 010$ \\
\hline Leptophysoderes_sarapiqui_14362 & 01001 & 10121 & 01011 & 02000 & 00010 & 10000 & 01320 & 02001 & $21 ? ? ?$ & $? ? ? ? ?$ \\
\hline Leptophysoderes_sarapiqui_14363 & 01101 & 10021 & 01011 & 02000 & 00010 & 10000 & 01320 & 02001 & $21 ? ? ?$ & ????? \\
\hline Nanophysoderes_dentiscutum_37370 & 11000 & 10111 & 01001 & 02000 & $0301 ?$ & 13110 & 01020 & 01201 & $10 ? ? ?$ & $? ? ? ? ?$ \\
\hline Paraphysoderes_popeye_52315 & 11100 & 10000 & 01001 & 00000 & 10110 & 13101 & 01121 & 01211 & 20210 & 11110 \\
\hline Physoderes_brevipennis_69376 & 21110 & 10001 & 01001 & 01000 & 03102 & 13001 & 01020 & $1-211$ & 10001 & 12110 \\
\hline Physoderes_muluensis_52311 & 11110 & 10121 & 01001 & 01000 & 03010 & 13001 & 01020 & 00111 & 10111 & 1010 \\
\hline Breviphysoderes_vestita_12260 & 21210 & 10101 & 01101 & 01000 & 03101 & 23101 & 01020 & 02211 & 10211 & 11112 \\
\hline Breviphysoderes_javanica_14054 & 21110 & 10101 & 01101 & 01000 & 03110 & 13101 & 01020 & 01211 & 10211 & 11112 \\
\hline Breviphysoderes_mjoebergi_14059 & 11110 & 10101 & 01101 & 01000 & 03110 & 23101 & 01020 & 01211 & $10 ? ? ?$ & $? ? ? ? ?$ \\
\hline Physoderes_notata_18526 & 21100 & $1012 ?$ & 01101 & 01000 & 03002 & 16101 & 01020 & 02211 & 10211 & 1010 \\
\hline Physoderes_fuliginosa_31288 & 21100 & 10121 & 01001 & 01000 & 03002 & 14101 & 01020 & 01211 & $10 ? ? ?$ & $? ? ? ? ?$ \\
\hline Physoderes_minime_31433 & 11110 & 10121 & 01001 & 01000 & 03002 & 04101 & 01020 & 00211 & $10 ? 01$ & 1200 \\
\hline
\end{tabular}


HWANG W.S. \& WEIRAUCH C., Phylogeny and revision of Physoderes and allied genera

Table 1. (Continued)

\begin{tabular}{|c|c|c|c|c|c|c|c|c|c|c|}
\hline & $\begin{array}{l}0 \\
0\end{array}$ & $\begin{array}{l}0 \\
5\end{array}$ & $\begin{array}{l}1 \\
0\end{array}$ & $\begin{array}{l}1 \\
5\end{array}$ & $\begin{array}{l}2 \\
0\end{array}$ & $\begin{array}{l}2 \\
5\end{array}$ & $\begin{array}{l}3 \\
0\end{array}$ & $\begin{array}{l}3 \\
5\end{array}$ & $\begin{array}{l}4 \\
0\end{array}$ & $\begin{array}{l}4 \\
5\end{array}$ \\
\hline Physoderes_ractepilosa_14061 & 21210 & 10021 & 01001 & 01000 & 03010 & 24101 & 01020 & 00111 & 10201 & 1020 \\
\hline Physoderes_nigripennis_14055 & 21210 & 10021 & 01101 & 02000 & 03010 & 26101 & 01020 & 01211 & $10 ? 01$ & 1020 \\
\hline Physoderes_tricolor_31439 & 21100 & 10011 & 01101 & 01000 & 03001 & 16101 & 01020 & 01211 & 10100 & 1010 \\
\hline Physoderes_impexa_52323 & 21100 & 10121 & 01101 & 01000 & 03011 & 26101 & 01020 & 01211 & $10 ? ? ?$ & ????? \\
\hline Physoderes_curculionis_73577 & 11100 & 10021 & 00001 & 01000 & 03001 & 13011 & 02020 & 00211 & 10100 & 12210 \\
\hline Physoderes_azrael & 11100 & 10021 & 01001 & 01000 & 03001 & 13011 & 01020 & 01211 & 10101 & 12110 \\
\hline Macrophysoderes_finisterre_69282 & 21100 & 10001 & 02111 & 01000 & 03010 & 13001 & 01020 & 01211 & 10110 & 10210 \\
\hline Macrophysoderes_cirripilosa_31396 & 21100 & 10101 & 02111 & 01000 & 03010 & 23001 & 01020 & 01211 & 10100 & $120 ? ?$ \\
\hline Macrophysoderes_grandis_52314 & 31110 & 10101 & 02111 & 01000 & 01110 & 23001 & 01020 & 02211 & 20100 & 12210 \\
\hline Macrophysoderes_bengalensis & 21000 & $1012 ?$ & 02101 & 00000 & 13010 & 22101 & 01120 & 01211 & 10100 & 10012 \\
\hline Macrophysoderes_monticola_69387 & 21010 & 10020 & 02101 & 00100 & 01010 & 16101 & 01020 & 01211 & $10 ? ? ?$ & $? ? ? ? ?$ \\
\hline
\end{tabular}

(12 of 38 sampled) and Neophysoderes Miller, 1955a (5 of 6 sampled). Species of Physoderes were selected to represent what we perceive as morphogroups that may not be monophyletic and therefore were important to include in this analysis. Ten newly described species are also included to determine their genus-level placement. Whenever the association between males and females was in doubt, such as when the type specimen and its allotype are morphologically different, both were included in the analysis.

\section{Morphological dataset}

Type specimens for all species were examined at the British Museum of Natural History (BMNH) and the Muséum national d'Histoire naturelle (MNHN). Additional specimens were loaned from different institutions and examined at the University of California, Riverside (UCR) using a Nikon SMZ1500 stereo microscope and recording morphological measurements. Scoring of characters was based on type specimens, plus additional identified material whenever available. A total of 57 morphological characters were coded using MESQUITE (Maddison \& Maddison 2011; Tables 1-2), 50 as discrete characters that are either binary ( 24 characters) or unordered multistate (26 characters). A total of 7 continuous characters based on ratios of body measurements were also included (Table 2).

\section{Analysis parameters}

A cladistic analysis was performed using a TNT (Goloboff et al. 2008) new technology search with initial level set at 50, 80 and 100, finding minimum length 10 times, and otherwise default settings. Symmetric resampling was performed using default settings for 500 replicates. Optimization of morphological characters on the resulting most parsimonious tree was performed in WinClada (Nixon 2002).

\section{Taxonomic revision}

\section{Specimens examined}

A total of 905 specimens were examined during the course of this study. The specimens were loaned from various museums (see list of museum acronyms below). Holotype specimens described by Miller were examined, documented and imaged at BMNH and MNHN. Additional images of type specimens from other institutions were provided by Yvonne van Nierop, Tadashi Ishikawa, Cai Wanzhi, Cao Liangming, and Dávid Rédei. Each specimen was labeled with a Unique Specimen Identifier (USI) and label information recorded and georeferenced in the Plant Bug Planetary Biodiversity Inventory (PBI) locality database (https://research.amnh.org/pbi/locality/) located at AMNH. Specimen examined 
Table 2. Measurements used as continuous characters in matrix. Note: total pronotal length excludes antero-lateral tubercles and paramedian lobes.

\begin{tabular}{|c|c|c|c|c|c|c|c|}
\hline & 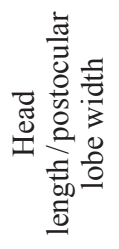 & 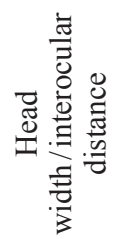 & 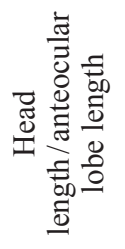 & 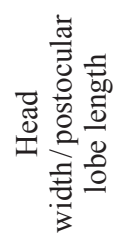 & 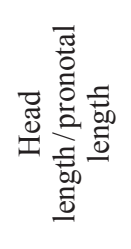 & 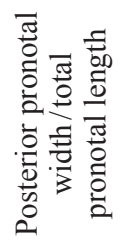 & 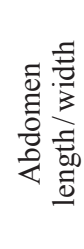 \\
\hline Microlestria_fuscicollis_52185 & 1.429 & 1.54 & 0.611 & 1.222 & 0.796 & 1.292 & 2.982 \\
\hline Nalata_squalida_2748 & 1.8 & 1.679 & 0.603 & 1.343 & 0.778 & 1.235 & 1.458 \\
\hline Aradomorpha_crassipes_14955 & 1.529 & 1.738 & 0.769 & 1.074 & 0.821 & 1.421 & 1.408 \\
\hline Paulianocoris_alternata_51269 & 1.964 & 1.65 & 0.727 & 1.179 & 0.733 & 1.2 & 1.413 \\
\hline Physoderes_mauricensis_51268 & 1.852 & 1.5 & 0.7 & 1 & 0.862 & 1.379 & 1.255 \\
\hline Epiroderoides_concoloripes_51275 & 2.133 & 1.737 & 0.688 & 1.1 & 0.79 & 1.21 & 1.585 \\
\hline Epiroderoides_bicoloripes_51276 & 2.2 & 1.65 & 0.682 & 1.1 & 0.957 & 1.232 & 0.818 \\
\hline Epiroderoides_geniculatus_51277 & 1.897 & 1.5 & 0.691 & 1.034 & 0.887 & 1.323 & 0.737 \\
\hline Epiroderoides_mauricensis_51278 & 1.828 & 1.429 & 0.679 & 1.034 & 0.779 & 1.309 & 1.271 \\
\hline Epiroderoides_mirabilis_51279 & 2.161 & 1.75 & 0.672 & 1.129 & 0.848 & 1.316 & 2.031 \\
\hline Epiroderoides_bipartitus_51280 & 1.943 & 1.68 & 0.662 & 1.2 & 0.828 & 1.363 & 1.511 \\
\hline Befotaka_granulosa_51264 & 2.042 & 1.647 & 0.673 & 1.167 & 1.167 & 1.31 & 1.758 \\
\hline Befotaka_tumidicollis_51265 & 2.143 & 1.545 & 0.667 & 1.214 & 1.017 & 1.203 & 1.363 \\
\hline Neophysoderes_dubia_51256 & 2.333 & 1.81 & 0.757 & 1.267 & 0.875 & 1.225 & $?$ \\
\hline Neophysoderes_dubia_51257 & 1.71 & 1.783 & 0.679 & 1.323 & 0.736 & 1.222 & 1.489 \\
\hline Neophysoderes_vadoni_51255 & 1.96 & 1.7 & 0.653 & 1.36 & 0.69 & 1.197 & 1.906 \\
\hline Neophysoderes_elongata_51258 & 2.143 & 1.727 & 0.65 & 1.357 & 0.822 & 1.192 & 1.612 \\
\hline Neophysoderes_pandanophila_51259 & 2.25 & 1.684 & 0.648 & 1.333 & 0.831 & 1.123 & 1.53 \\
\hline Neophysoderes_gigas_51260 & 2.355 & 1.826 & 0.685 & 1.355 & 0.82 & 1.27 & 1.772 \\
\hline Henicocephaloides_fulvescens_51273 & 2.455 & 1.786 & 0.704 & 1.136 & 1.038 & 1.288 & 1.212 \\
\hline Maroantsetrana_ridula_51274 & 2.083 & 2.071 & 0.68 & 1.208 & 0.926 & 1.241 & 1.892 \\
\hline Mimoelasmodema_depressa_51263 & 1.519 & 1.947 & 0.61 & 1.37 & 0.506 & 1.049 & 1.757 \\
\hline Paraphysoderes_peyrierasi_51261 & 1.913 & 1.8 & 0.614 & 1.174 & 0.786 & 1.268 & 1.328 \\
\hline Paraphysoderes_crassa_51262 & 2.143 & 1.6 & 0.644 & 1.143 & 0.789 & 1.246 & 1.356 \\
\hline Rodepirea_lobata_51271 & 2.333 & 1.667 & 0.696 & 1.25 & 0.982 & 1.053 & 2.07 \\
\hline Tribelocephaloides_gracilis_51272 & 2.706 & 2 & 0.696 & 1.176 & 1.243 & 1.514 & 2.086 \\
\hline Porcelloderes_impenetrabilis & 2.288 & 1.076 & 0.7 & 1.231 & $?$ & $?$ & 0.98 \\
\hline Physoderoides_browni_18523 & 2 & 1.556 & 0.68 & 1.12 & 0.806 & 1.258 & 1.245 \\
\hline Physoderoides_comorensis_51270 & 1.69 & 1.667 & 0.673 & 1.034 & 0.803 & 1.328 & 1.242 \\
\hline Leptophysoderes_sarapiqui_14360 & 2.116 & 1.537 & 0.633 & 1.125 & 1.053 & 1.347 & 1.475 \\
\hline Leptophysoderes_sarapiqui_14361 & 2.079 & 1.477 & 0.633 & 1.14 & 1.026 & 1.247 & 1.55 \\
\hline Cryptophysoderes_sp2_30202 & 2.082 & 1.6 & 0.595 & 1.194 & 0.93 & 1.28 & 1.562 \\
\hline Leptophysoderes_orellana & 1.714 & 2.002 & 0.6 & 1.143 & 1.518 & 1.404 & 1.416 \\
\hline Leptophysoderes_sarapiqui_14362 & 2.036 & 1.784 & 0.987 & 1.179 & 0.987 & 1.489 & 1.69 \\
\hline Leptophysoderes_sarapiqui_14363 & 1.947 & 1.789 & 0.676 & 1.193 & 0.925 & 1.467 & 1.675 \\
\hline Physoderes_notata_18526 & 2.067 & 1.7 & 0.677 & 1.133 & 0.775 & 1.25 & 1.792 \\
\hline Physoderes_fuliginosa_ 31288 & 2.188 & 1.545 & 0.686 & 1.063 & 0.795 & 1.288 & 1.419 \\
\hline Breviphysoderes_vestita_12260 & 2.125 & 1.733 & 0.686 & 1.083 & 0.857 & 1.303 & 1.308 \\
\hline
\end{tabular}


Table 2. (Continued)

\begin{tabular}{|c|c|c|c|c|c|c|c|}
\hline & 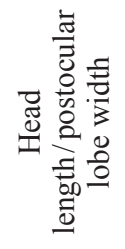 & 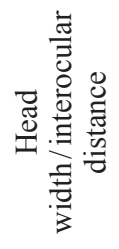 & 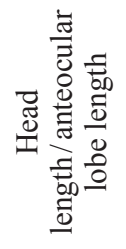 & 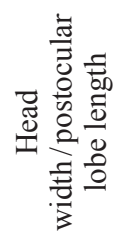 & 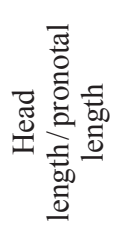 & 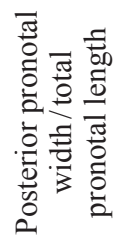 & 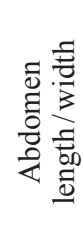 \\
\hline Breviphysoderes_javanica_14054 & 2.174 & 1.594 & 0.69 & 1.109 & 0.893 & 1.339 & 1.19 \\
\hline Physoderes_azrael & 1.867 & 1.517 & 0.667 & 0.978 & 0.84 & 1.4 & 1.449 \\
\hline Physoderes_nigripennis_14055 & 2.205 & 1.793 & 0.68 & 1.182 & 0.843 & 1.326 & 1.465 \\
\hline Physoderes_ractepilosa_14061 & 2.326 & 1.438 & 0.71 & 1.07 & 0.98 & 1.373 & 1.528 \\
\hline Physoderes_curculionis_73577 & 1.897 & 1.414 & 0.662 & 1.051 & 0.813 & 1.374 & 1.393 \\
\hline Paraphysoderes_popeye_52315 & 1.914 & 1.64 & 0.687 & 1.171 & 0.87 & 1.429 & 1.64 \\
\hline Macrophysoderes_grandis_52314 & 2.369 & 2.083 & 0.69 & 1.316 & 0.865 & 1.423 & 1.67 \\
\hline Physoderes_brevipennis_69376 & 2.093 & 1.679 & 0.69 & 1.093 & 0.857 & 1.238 & 1.414 \\
\hline Physoderes_muluensis_52311 & 2.297 & 1.615 & 0.671 & 1.135 & 1.012 & 1.31 & 1.53 \\
\hline Macrophysoderes_finisterre_69282 & 2.093 & 1.677 & 0.69 & 1.209 & 0.874 & 1.408 & 1.67 \\
\hline Physoderes_minime_31433 & 2.563 & 1.517 & 0.732 & 1.1 & 0.949 & 1.204 & 1.581 \\
\hline Physoderes_tricolor_31439 & 2.049 & 1.769 & 0.69 & 1.122 & 0.792 & 1.226 & 1.655 \\
\hline Macrophysoderes_bengalensis & 2.024 & 2.136 & 0.699 & 1.146 & 0.822 & 1.361 & 1.841 \\
\hline Macrophysoderes_monticola_69387 & 2.174 & 1.742 & 0.7 & 1.174 & 0.862 & 1.379 & 1.525 \\
\hline Physoderes_impexa_52323 & 2.152 & 1.559 & 0.707 & 1.152 & 0.825 & 1.333 & 1.818 \\
\hline Macrophysoderes_mjoebergi_14059 & 2.244 & 1.714 & 0.707 & 1.171 & 0.979 & 1.33 & 1.328 \\
\hline Macrophysoderes_cirripilosa_31396 & 2.125 & 1.815 & 0.682 & 1.225 & 0.842 & 1.337 & 1.613 \\
\hline Nanophysoderes_dentiscutum_37370 & 2.103 & 1.593 & 0.732 & 1.103 & 1 & 1.433 & 1.574 \\
\hline
\end{tabular}

information for each species was generated from the database and provided the basis for the "material examined" section as part of each species description.

Almost all locality labels lacked geographic coordinates and were therefore subsequently georeferenced using Google Earth. Localities with generic provincial or country information were georeferenced to the center of the least inclusive geographic region provided. Distribution maps were generated based on the georeferenced data and created using the AMNH Simple Mapper online tool linked to the PBI database. The maps are organized according to genus, except for Physoderes, which is split into two maps to avoid heavy overlap of specimen points.

\section{Morphological methods}

Habitus images were produced using either a Microptics-USA imaging system with a Canon EOS 1D camera or an Automontage GT-Vision imaging system. Images are either single exposures or combined from raw images using the Helicon Focus version 4.16 software or Archimed. To remove male genitalia, specimens were relaxed overnight in a hot water bath before soaking the apex of the abdomen in $10 \%$ potassium hydroxide $(\mathrm{KOH})$ for 2 hours. Male genitalia were dissected after being heated in a $10 \%$ $\mathrm{KOH}$ solution for 8 minutes, neutralized in water and transferred into $99 \%$ glycerol on a ceramic spot plate. The endosoma remained contracted for all specimens examined as we were unable to completely inflate it. The pygophores, parameres and phallus were dissected and mounted in a glycerin-gelatin mixture for imaging with an Automontage GT-Vision imaging system. Dissected genitalia were stored 
in glycerol in a genitalic vial and pinned with the specimen. All images and illustrations were edited and compiled into plates using Adobe Photoshop CS3 version 10.0.

Measurements were made using a dissecting microscope equipped with a 2-axes movable stage (Mitutoyo Corp.), with the aid of two digital micrometers (Boeckeler) which were connected to a Microcode II RS-232 digital readout (Boeckeler). Standardized genus and species descriptions were generated using DELTA (Dallwitz et al. 1999) using a customized template for Physoderinae using DELTA editor. This output was modified slightly to accommodate the format of the journal.

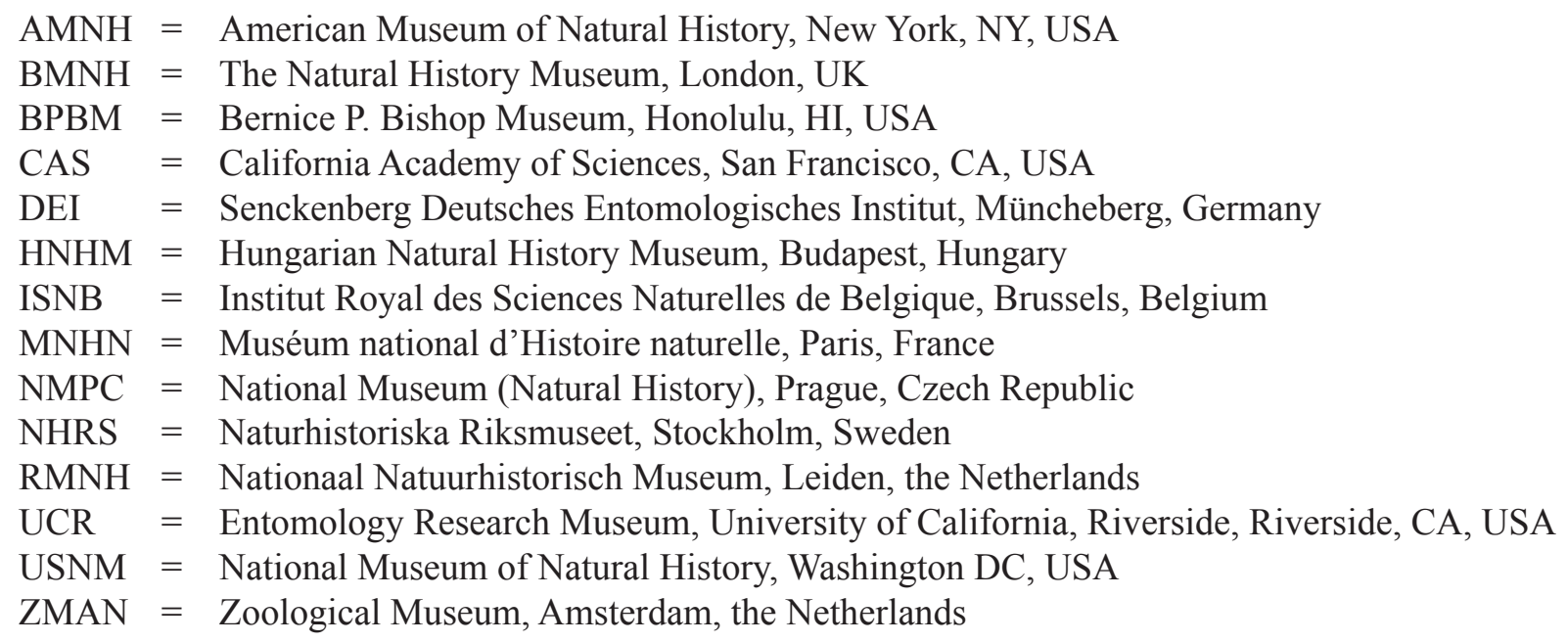

\section{Terminology}

Descriptive terminology of the male genitalia follows Davis (1966) and Forero \& Weirauch (2012). The pair of extended lobes projecting from the posterior margin of the posterior pronotal lobe are here referred to as parascutellar lobes. Setigerous tubercles here refer to seta-bearing tubercles found across the body, including on the legs, as used in Davranoglou et al. (2015). Body size descriptions here are grouped into four categories based on total body length: small $(6-8 \mathrm{~mm})$, medium $(8.01-10 \mathrm{~mm})$, large (10.01-11 mm), very large (11.01-13 mm).

\section{Results}

\section{Results of the phylogenetic analysis}

The morphological coding for each taxon is shown in Table 1, measurements used as continuous characters in Table 2, and the list of the morphological character states used in Table 3. The phylogenetic analysis consistently produced a single most parsimonious tree (length $=365, \mathrm{CI}=0.22, \mathrm{RI}=0.61$, Fig. 2 ; symmetric resampling values greater than 50 reported) that identified the Neotropical Aradomorpha as the sister-group to Physoderinae, the Afrotropical Porcelloderes as sister to all remaining Physoderinae and a monophyletic New World clade containing Leptophysoderes and Cryptophysoderes. The Madagascan Physoderinae are separated into at least two clades and are therefore not monophyletic (Fig. 2). Physoderes mauriciensis (Villiers, 1964) comb. nov., which is only known from Mauritius and is here transferred from Epiroderoides Villiers, 1962, is deeply nested within a clade that otherwise only includes Oriental and Australasian species of Physoderes, suggesting that Physoderes has expanded once into the Madagascan region. Clade A (Fig. 2) almost exclusively consists of Madagascan taxa, with the exception of Paraphysoderes popeye sp. nov., which we describe below as a new species from Papua New Guinea and which in our analysis is recovered as the sister taxon to the Madagascan species of Paraphysoderes Villiers, 1962. The remaining Madagascan genera (Clade B, Fig. 2) fall into two subclades, one comprised of the paraphyletic genus Neophysoderes Miller, 1955a and the 


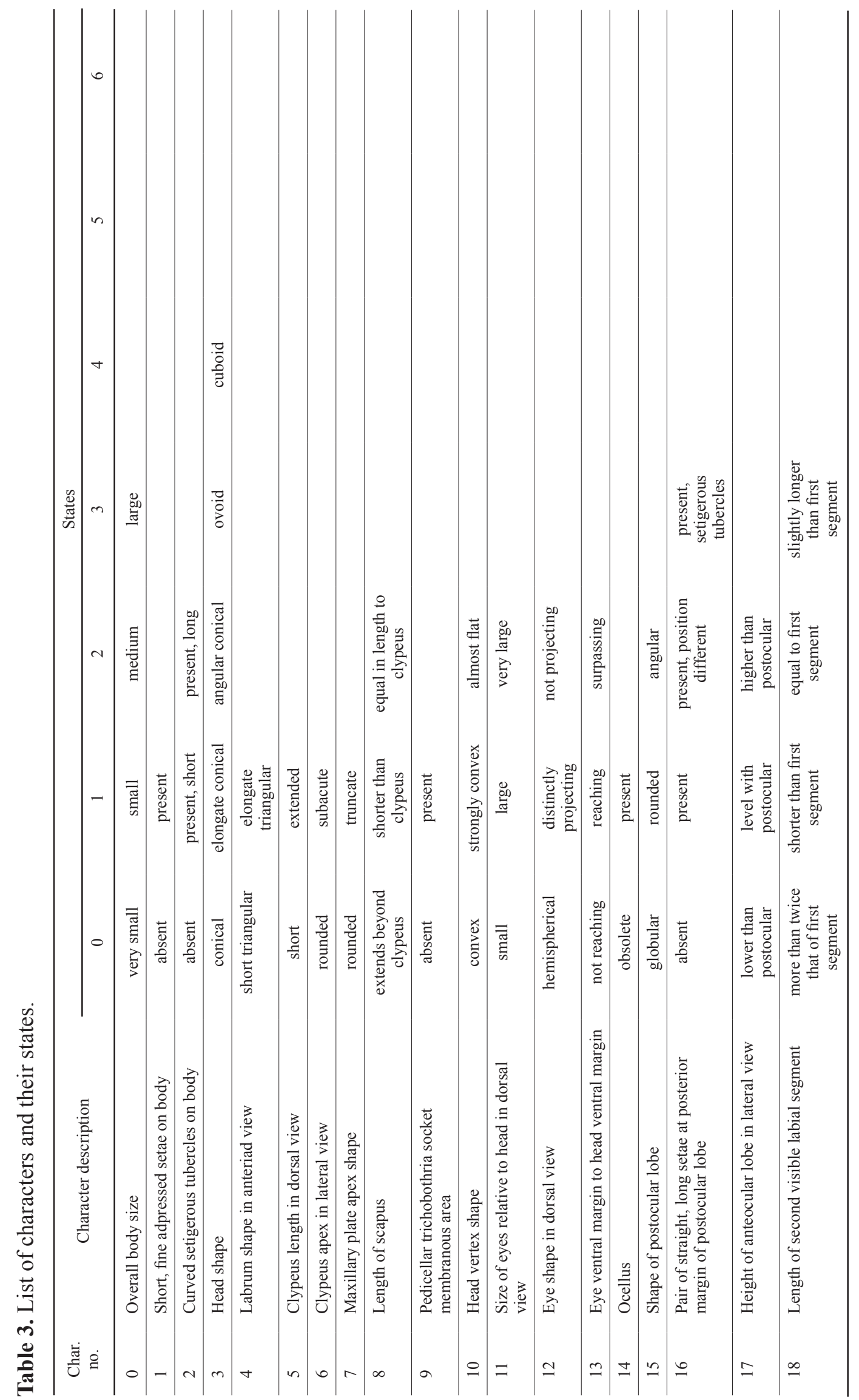




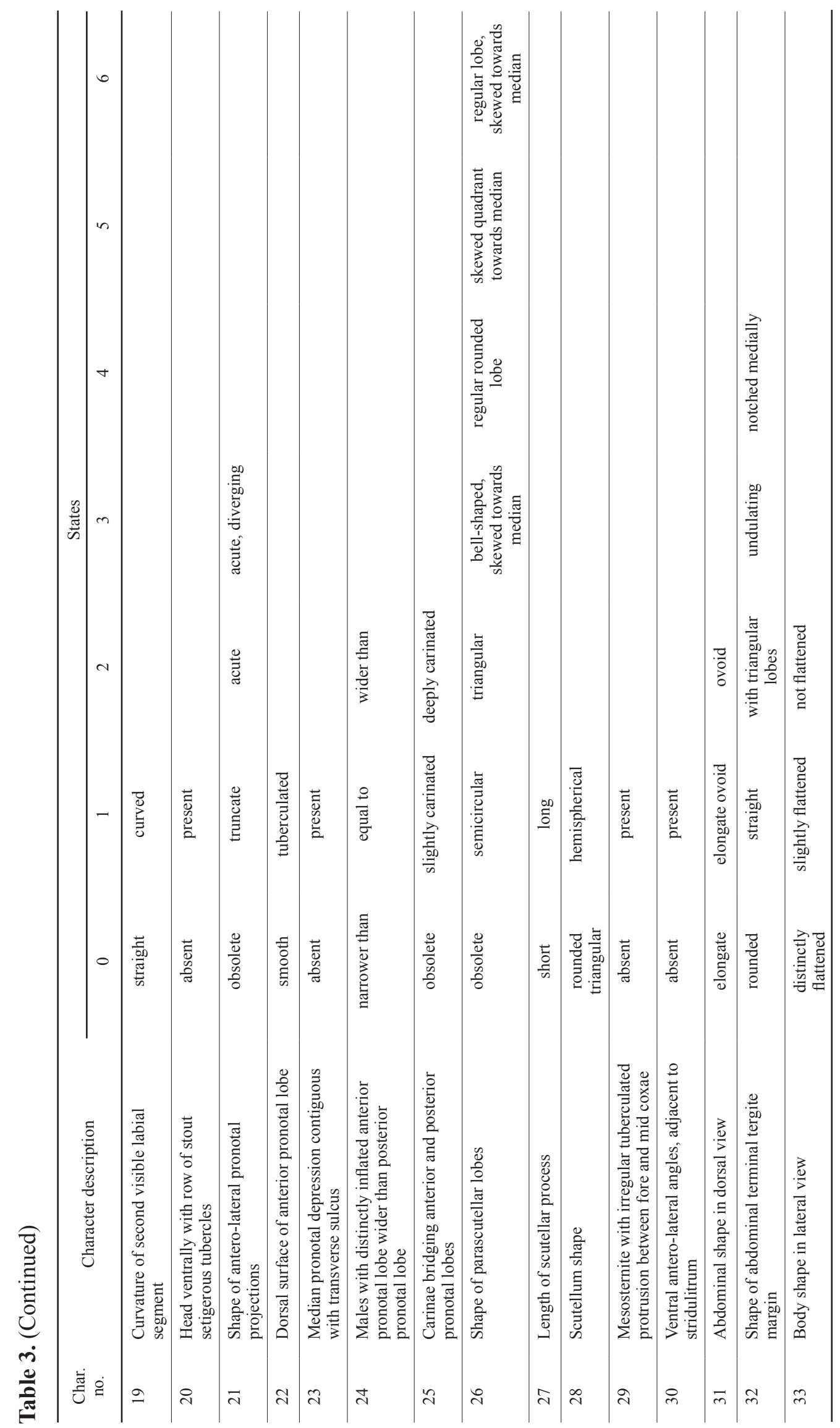




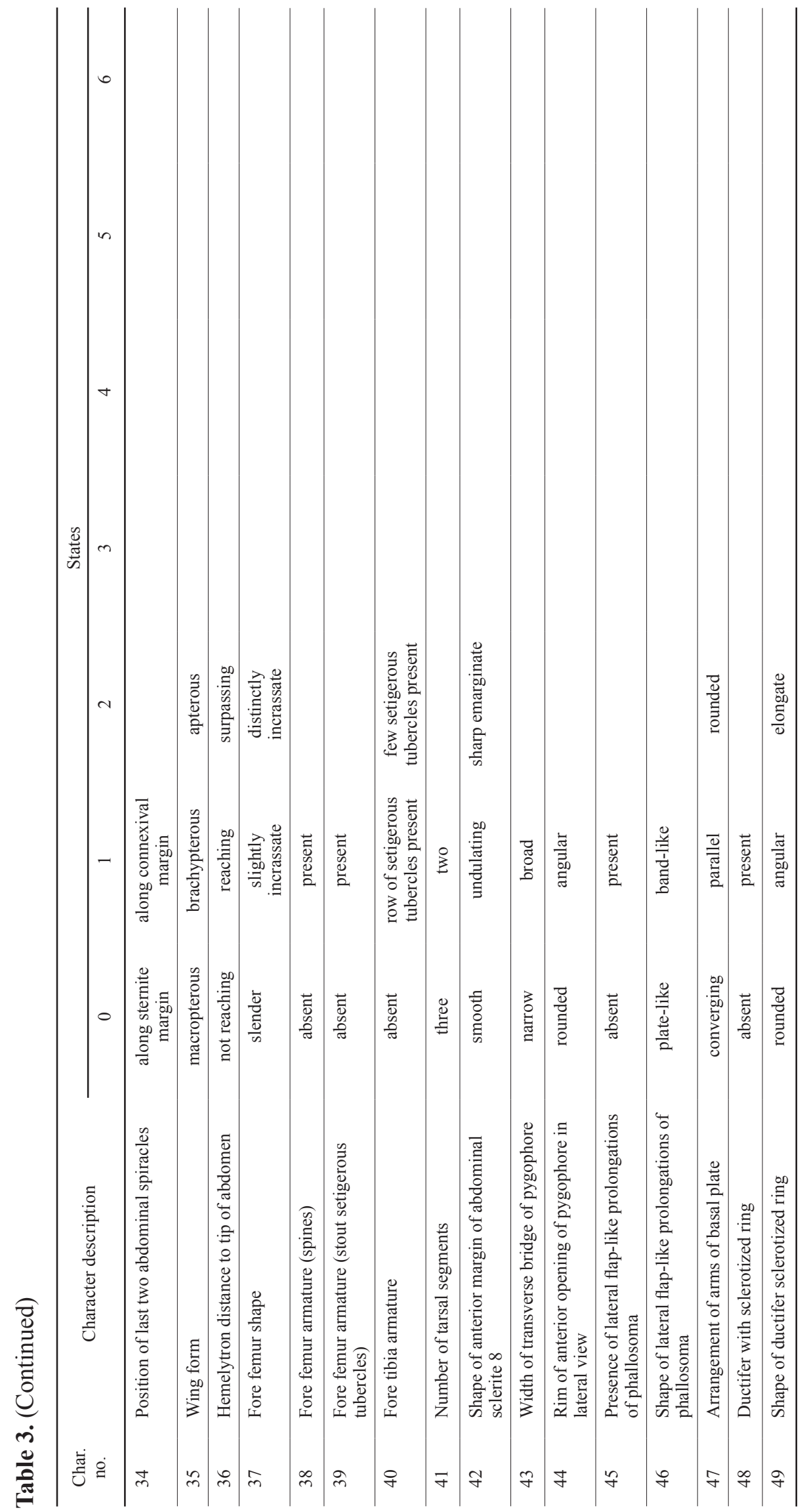


oddly dorso-ventrally flattened Mimoelasmodema depressa Villiers, 1962, the other containing all other documented Madagascan Physoderinae (Fig. 2). The two largest Madagascan genera, Neophysoderes and Epiroderoides, are not monophyletic; Epiroderoides is rendered paraphyletic by the remaining Madagascan physoderine genera included in Clade B. Similarly, our analysis indicates that Physoderes is polyphyletic, such that species that fall into three distinct clades and one single-species lineage are currently classified in this genus. We here propose a revised classification that splits Physoderes into four genera, describing three of them as new: Nanophysoderes gen. nov. for $N$. dentiscutum (Bergroth, 1906) comb. nov. from Indonesia, which is recovered as the sister species to all Oriental, Australasian, and Madagascan Physoderinae; Macrophysoderes gen. nov. for a clade currently comprised of eight previously described or new species with distributions ranging from peninsular Malaysia to Papua New Guinea; and Breviphysoderes gen. nov., also with eight species that are widely distributed in Southeast Asia. We refrain from re-classifying the two non-monophyletic Madagascan genera, pending additional character investigation.

The overall morphology of Physoderinae is rather conserved and identifying phylogenetically informative characters proved challenging. Most of the characters that vary between species are found on the head and pronotum. However, our analysis shows that many of these features tend to be homoplastic, either having evolved multiple times across the phylogeny or having been lost on some members of a clade.

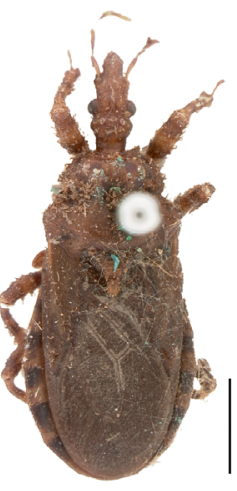

B. decora comb. nov. UCR_ENT 00031393

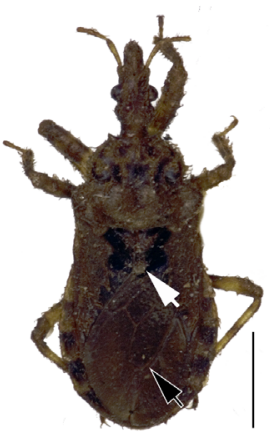

B. mjoebergi comb. nov. Holotype UCR_ENT 00018536

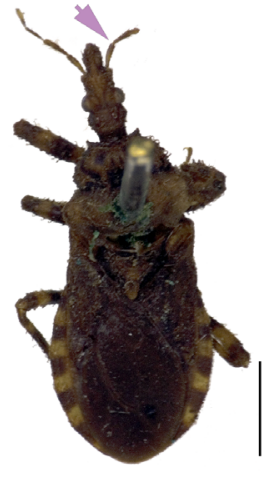

B. decora comb. nov. Holotype UCR_ENT 00018513

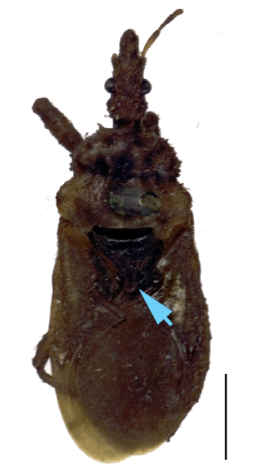

B. planicollis comb. nov. Holotype UCR_ENT 00018535
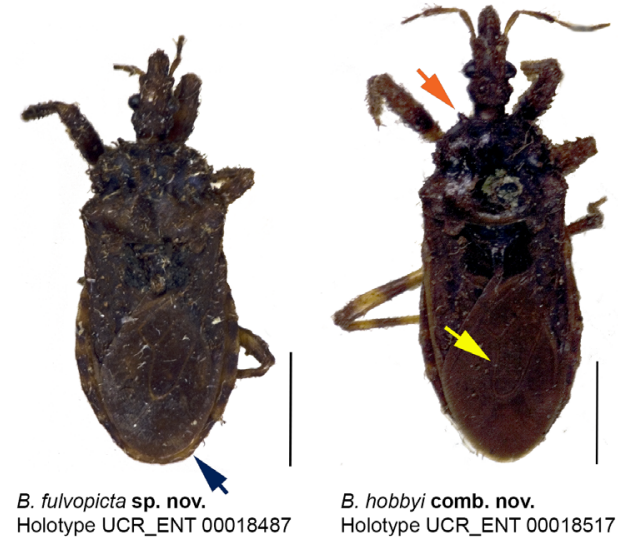

B. hobbyi comb. nov. Holotype UCR_ENT 00018517

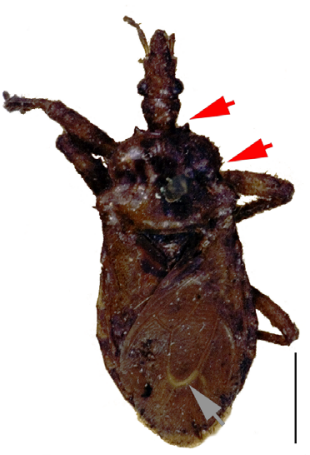

B. shelfordi comb. nov. Holotype UCR ENT 00018538

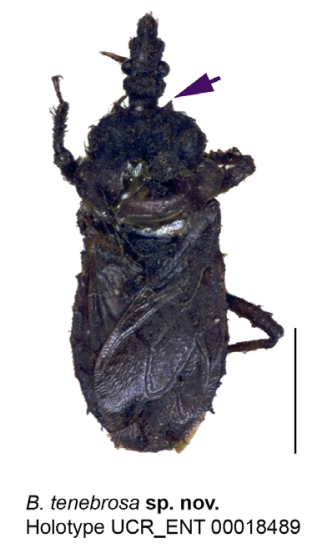

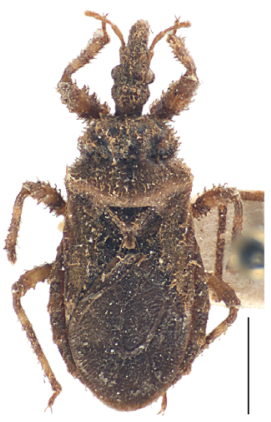

B. mjoebergi comb. nov. UCR_ENT 00014060

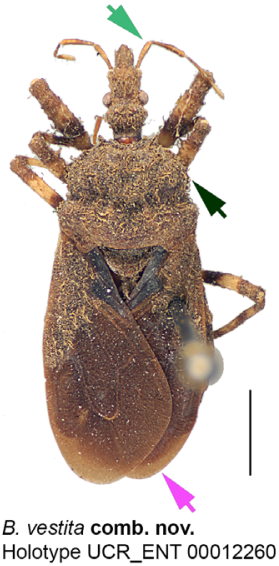

Fig. 4. Dorsal habitus images for species of Breviphysoderes gen. nov. For an explanation of the colored arrows, see key on page 17. Scale bars $=2 \mathrm{~mm}$. 


\section{Key to Oriental/Australasian Physoderinae genera}

1. Scutellum with distinct paired lateral tubercles; mesosternum with three longitudinal rows of setae Nanophysoderes gen. nov.

- Scutellum without paired lateral tubercles; mesosternum with one or no longitudinal rows of setae

2. Antero-lateral pronotal projection obsolete

Paraphysoderes Villiers, 1962

- Antero-lateral pronotal projection acute or truncated .3

3. Eyes very large, distinctly projecting in dorsal view, sometimes attaining ventral margin of head in lateral view; antero-lateral pronotal projection often truncate; pronotum glabrous

Macrophysoderes gen. nov.

- Eyes large, not distinctly projecting in dorsal view, not attaining ventral margin of head in lateral view; antero-lateral pronotal projection acute, not truncate (except $P$. nigripennis); pronotum with various forms of setation

4. Scape surpassing apex of clypeus; anterior pronotal lobe narrower than posterior lobe in both sexes; parascutellar lobes semicircular

- Scape not surpassing apex of clypeus; anterior pronotal lobe often wider than posterior lobe in males; parascutellar lobes rounded, often skewed towards median of pronotum

Phylum Arthropoda Latreille, 1829

Class Hexapoda Blainville, 1816

Order Hemiptera Linnaeus, 1758

Suborder Heteroptera Latreille, 1810

Family Reduviidae Latreille, 1807

Subfamily Physoderinae Miller, 1954

Breviphysoderes gen. nov. urn:1sid:zoobank.org:act:083107C2-6EAB-4DC4-BC2E-F5DAAF0F7A43

Figs 4-9, Appendix

\section{Diagnosis}

Recognized among all other genera of Physoderinae by the head being elongate conical, without a pair of long, straight setae on the posterior margin of the postocular lobe; the scape surpassing the apex of the clypeus; the eye being distinctly projecting in dorsal view; the pronotum with setigerous tubercles bearing short, curved setae; the anterior pronotal lobe always narrower than the posterior lobe in both sexes; the parascutellar lobe being semicircular; the posterior margin of the connexivum often being slightly elevated, with short, curved setae; the anterior margin of the male mediosternite 8 sharply emarginated; the cup-like sclerite of the pygophore apically rounded, with paired sclerotized latero-ventral slight protuberances; the arms of the basal plate parallel to each other; the sclerotized ring of the ductifer elongate; the dorsal phallothecal sclerite subacute, with lateral narrow; and the bandlike prolongations of the dorsal phallothecal sclerite extended diagonally towards the basal plate. Most similar to Physoderes, but distinguished by the scape surpassing the apex of the clypeus and the anterior pronotal lobe being narrower than the posterior lobe in males.

\section{Etymology}

Named after Physoderes, the type genus of the subfamily Physoderinae, in combination with "brevi" (Latin for "short") to indicate the shorter body length. The gender is feminine. 


\section{Type species}

Physoderes mjoebergi Miller, 1940.

\section{Description}

\section{Male}

Body LENGTH. Ranging from relatively small to medium-sized, 7.49-10.23 mm (Appendix).

Coloraton (Fig. 4). Variable, from straw-colored to dark brown. Head, anterior pronotal ridges, posterior pronotal lobe, legs and corium of similar lighter coloration, anterior pronotal lobe, scutellum and claval region with darker coloration.

Vestiture. Densely setose with curved setae, strongly tuberculated on head, along pronotal margin and ridges.

HEAD. Elongate conical; maxillary plate truncate apically; scape surpassing apex of clypeus except in Breviphysoderes decora comb. nov.; eye distinctly projecting in dorsal view except in $B$. decora comb. nov., not attaining head ventral margin in lateral view; height of anteocular lobe shorter than postocular lobe, ocelli present.

THorax. Antero-lateral paired projections acute, oriented anteriorly or diverging; surface of anterior lobe with low ridges; median pronotal depression contiguous with transverse sulcus in males except in Breviphysoderes vestita comb. nov.; paramedian carina strongly defined except in B. decora comb. nov.; posterior lobe medially rugose; anterior pronotal lobe of equal length to posterior lobe, narrower than posterior lobe in both sexes, anterior lobe lower than posterior lobe in lateral view except in $B$. vestita comb. nov.; parascutellar lobe semicircular; scutellum rounded triangular, scutellar process long, with rounded apex, except in $B$. decora comb. nov.; mesosternite usually with median irregular tuberculated protrusion between fore and mid coxae.

Hemelytron. Macropterous, hemelytron length variable.

LEGS. Fore femur distinctly incrassate; tarsus three-segmented.

ABdomen. Elongate ovoid, with rounded or straight terminal margin; connexival margin slightly undulating except in Breviphysoderes planicollis comb. nov., posterior margin most often slightly elevated.

Genitalia. Anterior margin of mediosternite 8 sharply emarginate, with or without medial apodeme; transverse bridge of pygophore broad, margin of anterior opening angular, with apodeme present, apical margin of posterior opening smooth; cup-like sclerite apically rounded, with sclerotized paired latero-ventral slight protuberance; arms of basal plate parallel to each other; ductifer with sclerotized, elongate ring; endosomal struts conical, with subacute apex, basally divided into two arms; apex of dorsal phallothecal sclerite subacute or rounded, with lateral narrow band-like prolongations oriented diagonally towards basal plate.

\section{Female}

Similar in shape and coloration to males but slightly larger or having a wider abdomen or narrower anterior pronotal lobe.

\section{Ecology}

Specimens have been collected from dead plant material, tree bark and in the undergrowth. Different species have been found at different elevations with $B$. vestita comb. nov. collected at the highest altitude of $1955 \mathrm{~m}$. 


\section{Distribution}

This genus currently comprises 8 described and new species and is widely distributed across Southeast Asia; found in continental Indochina, peninsular Malaysia, Sumatra, Java and Borneo. The highest species diversity for this genus is in Borneo.

\section{Key to species of Breviphysoderes gen. nov.}

1. Apical portion of veins forming external cell of hemelytron $(\mathrm{Cu}+\mathrm{M})$ straw-colored or distinctly lighter than remainder of veins (Fig. 4, grey arrow)

- Veins framing external cell of hemelytron uniformly colored, not straw-colored (Fig. 4, black arrow)

2. Hemelytron short, not reaching tip of abdomen (Fig. 4, blue arrow) ....B. fulvopicta gen. et sp. nov.

- Hemelytron reaching or surpassing tip of abdomen (Fig. 4, pink arrow)

3. Antero-lateral pronotal projections diverging, males with anterior pronotal lobe enlarged, wider than in females, as wide or almost as wide as posterior lobe (Fig. 4, dark green arrow)

B. vestita (Horváth, 1900) comb. nov.

- Antero-lateral pronotal projections oriented anteriorly, males with anterior pronotal lobe as in females, narrower than posterior lobe (Fig. 4, red arrows) ......B. shelfordi (Miller, 1940) comb. nov.

4. Head and body uniformly brownish-black, antero-lateral pronotal projections acute, oriented anteriorly (Fig. 4, purple arrow)

B. tenebrosa gen. et sp. nov.

- Head and body not uniformly brownish black, antero-lateral pronotal projections acute and diverging (Fig. 4, orange arrow) .5

5. Scape reaching, but not surpassing apex of clypeus (Fig. 4, light purple arrow)

- Scape surpassing apex of clypeus (Fig. 4, light green arrow)

B. decora (Miller, 1940) comb. nov.

6. Ridges of anterior pronotal lobe dark brown, similar in color to remainder of anterior pronotal lobe; external cell of hemelytron $(\mathrm{Cu}+\mathrm{M})$ elongated (Fig. 4, yellow arrow)

B. hobbyi (Miller, 1940) comb. nov.

- Ridges of anterior pronotal lobe straw-colored, color contrasting with remainder of anterior pronotal lobe; external cell of hemelytron $(\mathrm{Cu}+\mathrm{M})$ not elongated (Fig. 4, black arrow)

7. Apex of scutellar process straw-colored (Fig. 4, white arrow)

B. mjoebergi (Miller, 1940) comb. nov.

- Apex of scutellar process dark brown or uniform color as scutellum (Fig. 4, light blue arrow) ..

..B. planicollis (Miller, 1940) comb. nov.

Breviphysoderes decora (Miller, 1940) comb. nov.

Figs 4-7; Appendix

Physoderes decora Miller, 1940: 551, fig. 91.

Physoderes ostenta Miller, 1941: 780, fig. 6. New synonymy.

\section{Diagnosis}

Recognized among other species in the genus by the scape almost reaching or reaching clypeus apex, the dorsal surface of the anterior pronotal lobe tuberculated, the color pattern on the anterior pronotal lobe, the small and semicircular parascutellar lobes, the short and apically straw-colored scutellar process, the 
hemelytron attaining the apex of the abdomen, and the anterior half of the connexivum brown and the posterior half straw-colored. It most closely resembles B. mjoebergi (Miller 1940) comb. nov., but can be differentiated by the scape not extending beyond the clypeal apex and the shorter scutellar process for B. mjoebergi comb. nov.

\section{Material examined}

\section{Holotype}

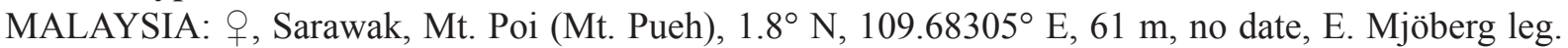
(UCR_ENT 00018513) (BMNH).

\section{Paratype}

MALAYSIA: 1 q, Sabah, N Borneo, Bettotan, nr. Sandakan, 5.28222 ${ }^{\circ}$ N, 117.59305 E, 6 Aug. 1927, C. Boden Kloss and H.M. Pendlebury leg. (UCR ENT 00018510) (BMNH).

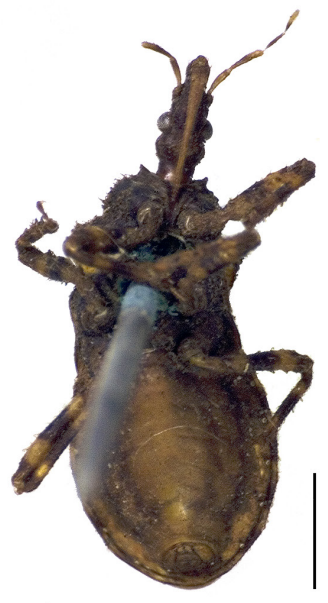

B. decora comb. nov. Holotype UCR_ENT 00018513

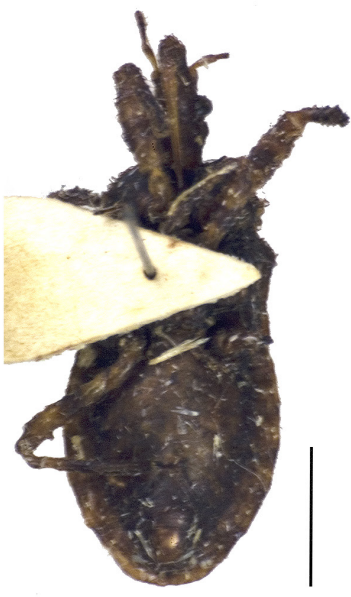

B. fulvopicta sp. nov. Holotype UCR_ENT 00018487

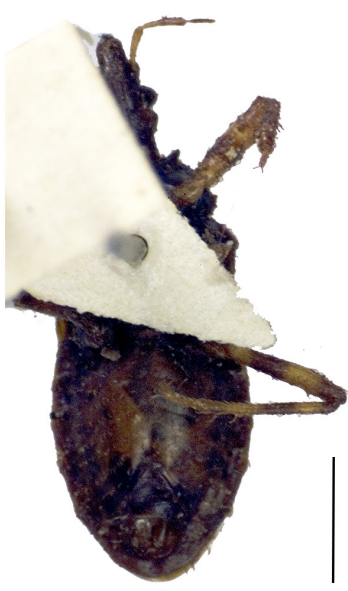

B. hobbyi comb. nov. Holotype UCR_ENT 00018517

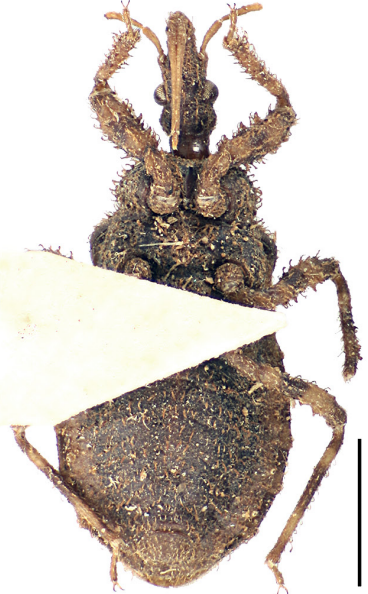

B. mjoebergi comb. nov. UCR_ENT 00014060

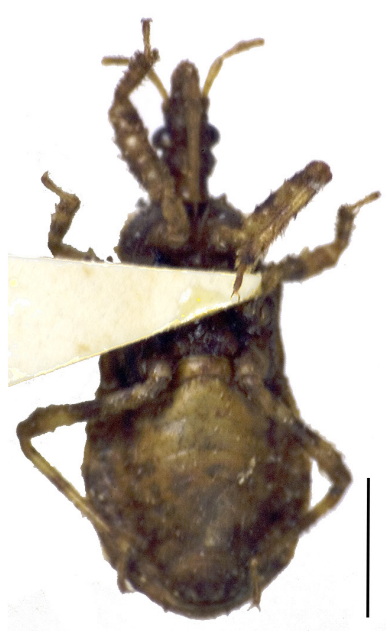

B. mjoebergi comb. nov. Holotype UCR_ENT 00018536

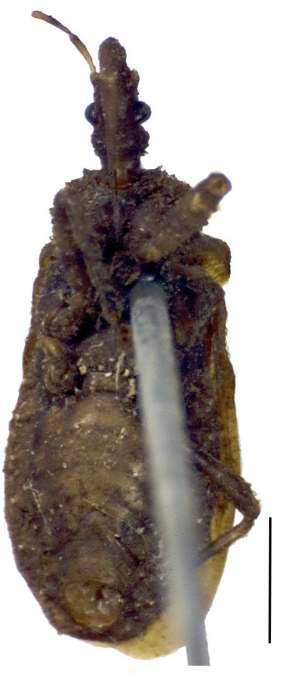

B. planicollis comb. nov. Holotype UCR_ENT 00018535

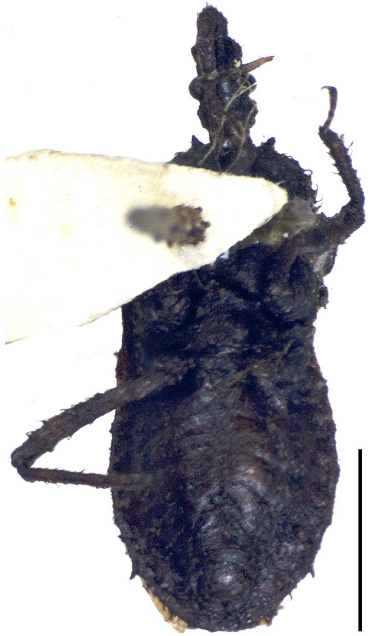

B. tenebrosa sp. nov. Holotype UCR_ENT 00018489

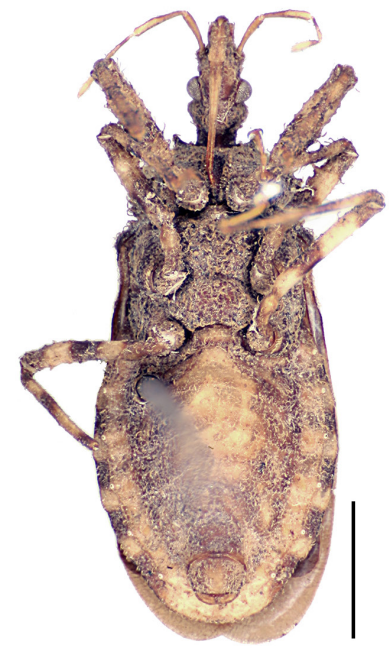

B. vestita comb. nov. Holotype UCR_ENT 00012260

Fig. 5. Ventral habitus images for species of Breviphysoderes gen. nov. Scale bars $=2 \mathrm{~mm}$. 


\section{Other material}

BRUNEI DARUSSALAM: 1 क, Temburong District, Kuala Belalong Field Studies Center, $4.54716^{\circ} \mathrm{N}, 115.15825^{\circ} \mathrm{E}, 82 \mathrm{~m}, 26$ Jun. 2010, C. Weirauch and W. Hwang leg. (UCR_ENT 00052186) (UCR).

MALAYSIA: Perak: 1 ㅇ, Batang Padang, Jor Camp, 3.52972 N, $101.55277^{\circ}$ E, 549 m, 4 Jun. 1923, H.M. Pendlebury leg., holotype of P. ostenta (junior synonym) (UCR_ENT 00018522) (BMNH). Sabah: 1 ㅇ, Mile 50 Lungmanis, $5.42027^{\circ}$ N, $116.79638^{\circ}$ E, 9 Aug. 1967, F.E. leg. (UCR_ENT

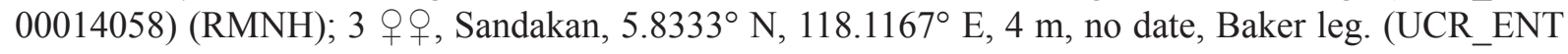
00031391-UCR_ENT 00031393) (USNM).

\section{Redescription}

\section{Female}

Body Length. Medium, total length $9.19 \mathrm{~mm}, \mathrm{SD} \pm 0.33$ (Appendix).

Coloration (Figs 4-5, 7). Straw-colored and brown. Head brown with straw-colored suffusion. Scape of antenna straw-colored with brown apex, pedicel brown with straw brown apex, basi-flagellomere brown, distiflagellomere brown with straw brown apex. Labium light brown. Anterior lobe of pronotum dark brown with straw-colored patterns, posterior lobe straw brown, scutellum dark brown with straw-colored apex, pleuron brown with straw brown suffusion, sternum brown. Corium and membrane of hemelytron brown to dark brown. Femora of legs straw-colored with medial and apical brown annulations, tibiae brown with sub-basal and apical straw-colored annulations, tarsus and claw light brown. Abdomen dorsally straw brown with orange suffusion, ventrally light brown with brown suffusion, anterior half of connexivum brown, posterior half straw brown.

VestiTURE. Sparsely setose. Head with widespread curved, setigerous tubercles, ventral surface of postocular lobe with sparse, setigerous tubercles, without pair of long, straight setae on postocular lobe posterior to ocelli. Anterior lobe of thorax with tuberculated, short, curved setae on lateral margins and along dorsal ridges, posterior lobe with short, curved, setigerous tubercles along lateral margins and sparsely distributed on dorsal surface. Corium of hemelytron with short, curved setae. Legs with two rows of spines and setigerous tubercles, tibia with regular rows of tuberculated, stout, sharp setae. Posterior margin of connexivum with short, curved setae.

HEAD. Scape reaching apex of clypeus; eye hemispherical in dorsal view, less than $1 / 5$ length of head, not attaining ventral margin of head in lateral view.

THORAX. Antero-lateral paired projections acute, diverging; median pronotal depression contiguous with transverse sulcus; paramedian carina weakly defined; scutellar process short, apex subacute; mesosternite with setigerous tubercles but no protrusion.

HemeLYtron. Attaining tip of abdomen.

LEGS. Same as genus description.

AвDomen. Elongate ovoid, with rounded terminal margin; connexival margin slightly undulating, posterior margin not elevated.

Genitalia. Not dissected.

Male

Unknown. 


\section{Ecology}

Little known, specimens collected from altitude of $82 \mathrm{~m}$ to $549 \mathrm{~m}(1800 \mathrm{ft})$. Coloration of specimens differs slightly, but it is unclear whether this is due to natural variation or preservation history.

\section{Distribution}

Found across Northern Borneo from east (Bettotan, Sandakan) to west (Mt. Poi), and also one specimen from Peninsular Malaysia (Perak, Jor Camp).

\section{Remarks}

Physoderes ostenta is synonymized with $B$. decora comb. nov. as it shares the same diagnostic features, including scape almost reaching or reaching clypeal apex, short scutellar process and straw brown apex, hemelytron attaining the abdominal apex, anterior half of the connexivum brown, and posterior half straw brown. No other specimen of P. ostenta exists besides the holotype. Breviphysoderes decora comb. nov. is removed from Physoderes and transferred to Breviphysoderes gen. nov. because it possesses the synapomorphies of the new genus (parascutellar lobes are semicircular and have prominent setigerous tubercles on the dorsal ridges of the anterior pronotallobe). One specimen originally designated as a P. hobbyi paratype(UCR ENT00018511)isconsidered to be misidentified byMillerandisheretreated as belonging to B. decora comb. nov. This species is known only from female specimens. Currently there are no males that can be associated with these females and hence the redescription is based on females only.

Breviphysoderes fulvopicta gen. et sp. nov. urn:1sid:zoobank.org:act:27A9078A-D5EB-45B2-A579-5D8F5746288D

Figs 4-6; Appendix

\section{Diagnosis}

Recognized among species of Breviphysoderes gen. nov. by having the head and anterior pronotal lobe distinctly covered with dense, short, curved, setigerous tubercles, the pronotal paramedian carina deeply defined, the apical veins of the external cell of the hemelytron $(\mathrm{Cu}+\mathrm{M})$ and the apex of the scutellar process with distinct straw-colored marks, and the hemelytron not attaining the tip of the abdomen. This species is most similar to $B$. hobbyi comb. nov. and $B$. decora comb. nov. It can be differentiated from the former species by the hemelytron not attaining the tip of the abdomen, the straw-colored apical veins of the external cell and the shorter external cell length. It differs from $B$. decora comb. nov. in having the scape surpassing the apex of the clypeus and in having the apical veins of the external cell straw-colored. The straw-colored mark on the apical veins of the external cell is also present in B. vestita comb. nov. and $B$. shelfordi comb. nov., but the anterior pronotal lobe is wider in $B$. vestita comb. nov. and the hemelytron is longer and surpasses the tip of the abdomen in $B$. shelfordi comb. nov.

\section{Etymology}

The name fulvopicta is an adjective derived from Latin "fulvus" meaning reddish yellow and "pictus" meaning decorated to describe the distinctive straw-colored apical veins of the external cell of the hemelytron.

\section{Material examined}

\section{Holotype}

MALAYSIA: ${ }^{\top}$, Sarawak, River Kapah, tributary of River Tinjar, $3.34261^{\circ} \mathrm{N}, 114.30208^{\circ}$ E, $174 \mathrm{~m}, 23$ Nov. 1932, B.M. Hobby and A.W. Moore leg. (UCR_ENT 00018487) (BMNH). 
Paratypes

MALAYSIA: $1{ }^{\lambda}$, Sarawak, foot of Mt. Dulit, junction of Rivers Tinjar and Lejok, $3.32388^{\circ} \mathrm{N}$, $114.14722^{\circ}$ E, 730 m, 28 Aug. 1932, B.M. Hobby and A.W. Moore leg. (UCR_ENT 00018512) (BMNH); 1 ${ }^{\top}$, same collection data as preceding but 5 Sep. 1932 (UCR_ENT 00018488) (BMNH).

\section{Description}

Male

Body Length. Small size, total length $7.07 \mathrm{~mm}$.

Coloration (Figs 4-5). Light brown to dark brown. Head light brown to dark brown. Scape of antenna straw-colored, with apex brown, pedicel straw-colored and medially brown, basiflagellomere dark brown, distiflagellomere dark brown with straw-colored apex. First segment of labium brown or dark brown, second segment light brown and basally and apically brown or dark brown entirely, third segment brown or dark brown. Anterior lobe of pronotum dark brown with straw-colored ridges, posterior lobe light brown or brown, scutellum dark brown with straw-colored apex, pleuron dark brown entirely or with brown suffusion, sternum dark brown. Corium of hemelytron brown, membrane brown with apical veins of external cell $(\mathrm{Cu}+\mathrm{M})$ straw-colored. Femora of legs straw-colored or light brown with medial and apical dark brown annulations, tibiae straw-colored or brown with basal, medial and apical dark brown annulations, tarsi and claws light-brown or brown. Abdomen not examined dorsally, ventrally light brown medially with lateral suffusion to dark brown or entirely dark brown, anterior half of connexivum dark brown and posterior half straw-colored, or dark brown entirely, exposed part of pygophore variable, light brown to dark brown.

Vestiture. Densely setose. Head with widespread curved, setigerous tubercles, ventral surface of postocular lobe with sparse, setigerous tubercles, without pair of long, straight setae on postocular lobe posterior to ocelli. Anterior lobe of thorax with tuberculated, short, curved setae on lateral margins and along dorsal ridges, posterior lobe with short, curved, setigerous tubercles along lateral margins and sparsely distributed on dorsal surface. Corium of hemelytron with short, curved setae. Fore femur of legs with two rows of spines and setigerous tubercles, fore tibia with regular rows of tuberculated, stout, sharp setae. On abdomen, posterior margin of connexivum with short, curved setae.

HEAD. Scape surpassing apex of clypeus; eye distinctly projecting in dorsal view, about $1 / 5$ length of head, not attaining ventral margin of head in lateral view.

THORAX. Antero-lateral paired projections acute, diverging; median pronotal depression contiguous with transverse sulcus; paramedian carina strongly defined; scutellar process long, with rounded apex; mesosternite with median irregular, tuberculated protrusion between fore and mid coxae.

HEMELYTRON. Not attaining tip of abdomen.

LEGS. Same as genus description.

AвDOMEN. Elongate ovoid, with straight terminal margin; connexival margin slightly undulating, posterior margin slightly elevated.

Genitalia. Not examined.

\section{Female}

Unknown. 


\section{Ecology}

This species is found in the tropical forest of Borneo and has been collected from the undergrowth, sapwood just under bark, and flood refuse and cut reeds at the junction of rivers.

\section{Distribution}

This species is known only from the type locality of Mt Dulit in Sarawak, north-central Borneo. All three specimens were collected near each other, at the foot of Mt Dulit near the River Tinjar.

\section{Remarks}

This species is described based on three specimens originally designated as paratypes of $B$. hobbyi (Miller, 1940) comb. nov. Even though they share the same collecting event and locality as that of B. hobbyi, closer examination shows distinct, consistent, morphological differences and the specimens are therefore described as a separate species. The specimens were collected by B.M. Hobby and A.W. Moore during the Oxford University Expedition in 1932. The darkened scutellum and overlapping distribution shared with B. hobbyi comb. nov., B. decora comb. nov., B. planicollis comb. nov. and $B$. tenebrosa gen. et sp. nov. suggest that they are likely to be closely related.

Breviphysoderes hobbyi (Miller, 1940) comb. nov. Figs 4-6; Appendix

Physoderes hobbyi Miller, 1940: 554, fig. 92.

\section{Diagnosis}

This species is recognized among species of Breviphysoderes by the head and anterior pronotal lobe being distinctly covered with dense, short, curved, setigerous tubercles, the deeply defined pronotal paramedian carina, the hemelytron surpassing the tip of the abdomen, the medial vein of the hemelytron shaped like an inverted $\mathrm{S}$, and the elongated external cell of the hemelytron $(\mathrm{Cu}+\mathrm{M})$. This species is most similar to B. tenebrosa gen. et sp. nov. and B. planicollis comb. nov. It can be differentiated from the former by the overall coloration, the diverging antero-lateral pronotal projections, and the shape of the external cell. It differs from B. planicollis comb. nov. by the overall coloration and the shape of the external cell.

\section{Material examined}

\section{Holotype}

MALAYSIA: §`, Sarawak, Mt Dulit, Dulit Trail, $3.32388^{\circ}$ N, $114.1475^{\circ}$ E, 730 m, 3 Sep. 1932, B.M. Hobby and A.W. Moore leg. (UCR_ENT 00018517) (BMNH).

\section{Redescription}

\section{Male}

Body LENGTH. Medium size, total length $8.7 \mathrm{~mm}$.

Coloration (Figs 4-5). Light brown with dark brown patterns. Head brown. Scape of antenna strawcolored with light brown apex, basal half of pedicel straw-colored and apical half brown, basiflagellomere brown and distiflagellomere brown with light brown apex. Labium brown. Anterior lobe of pronotum dark brown, posterior lobe brown, scutellum dark brown with brown apex, pleuron dark brown with brown suffusion. Corium and membrane of hemelytron brown. Femora of legs straw-colored with medial dark brown annulation and apical dark brown suffusion, tibiae straw-colored with basal, medial and apical dark brown annulations, tarsi and claws straw-colored. Abdomen not examined dorsally, 


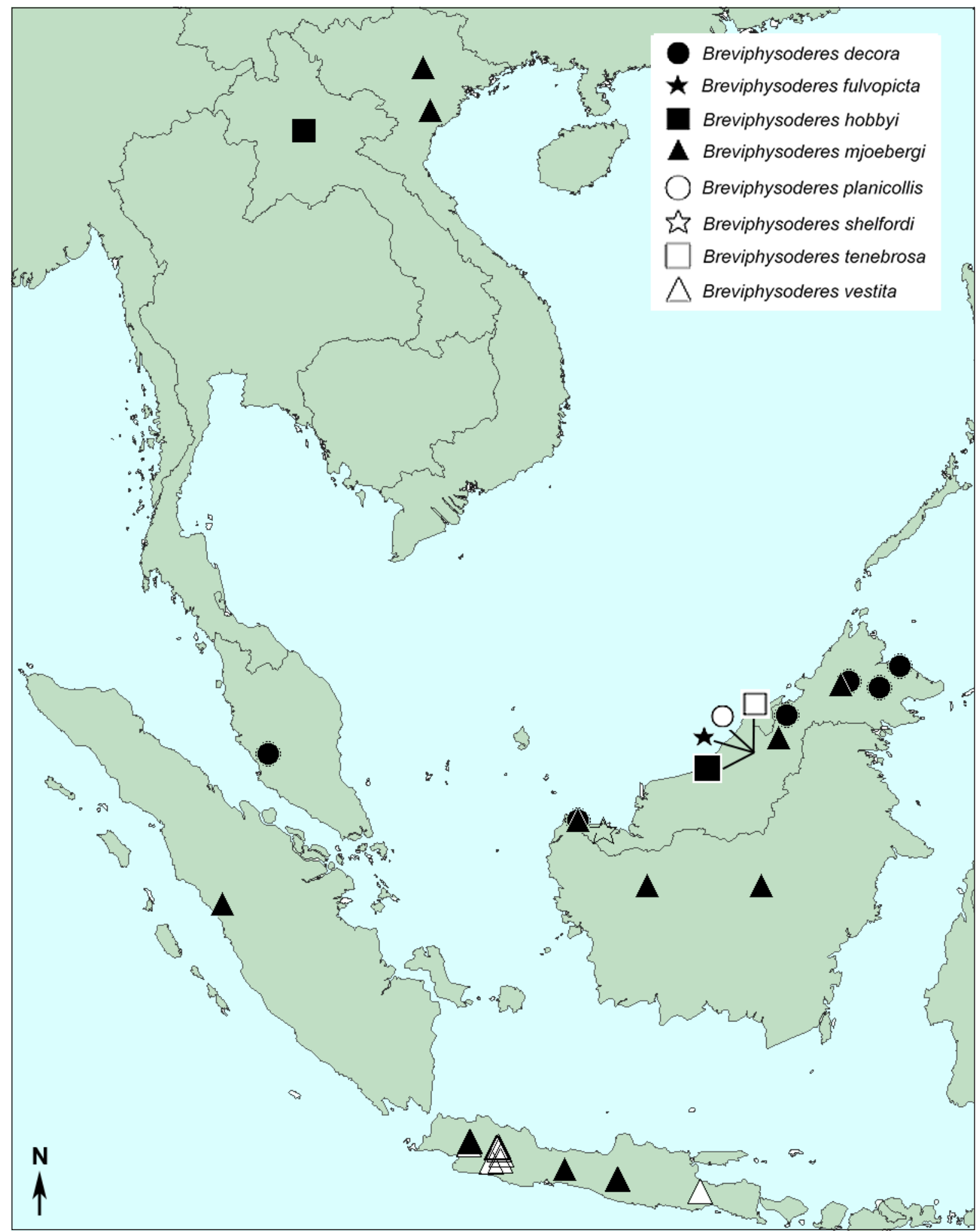

Fig. 6. Distribution map for species of Breviphysoderes gen. nov. 
ventrally light brown medially with lateral suffusion to dark brown, connexivum dark brown with apex straw-colored, exposed part of pygophore brown.

VestiTuRe. Sparsely setose. Head with widespread curved, setigerous tubercles, ventral surface of postocular lobe with sparse, setigerous tubercles, without pair of long, straight setae on postocular lobe posterior to ocelli. Anterior lobe of thorax with tuberculated, short, curved setae on lateral margins and along dorsal ridges, posterior lobe with short, curved, setigerous tubercles along lateral margins and sparsely distributed on dorsal surface. Corium of hemelytron with short, curved setae. Legs with two rows of spines and setigerous tubercles, tibiae with regular rows of tuberculated, stout, sharp setae. Posterior margin of connexivum with short, curved setae.

HEAD. Scape surpassing apex of clypeus; eye distinctly projecting in dorsal view, about $1 / 5$ length of head, not attaining ventral margin of head in lateral view.

ThORAX. Antero-lateral paired projections acute, diverging; median pronotal depression contiguous with transverse sulcus; paramedian carina strongly defined; posterior lobe damaged/obscured medially by pin; scutellar process long, with rounded apex; mesosternite with median irregular, tuberculated protrusion between fore and mid coxae.

Hemelytron. Surpassing tip of abdomen.

LEGS. Same as genus description.

AвDOMEN. Elongate ovoid, with rounded terminal margin; connexival margin slightly undulating, posterior margin slightly elevated.

Genitalia. Not examined.

\section{Female}

Unknown.

\section{Ecology}

This species is found in old secondary forest of Borneo.

\section{Distribution}

This species is only known from the type locality of Mt Dulit in Sarawak, north-central Borneo. The type locality is shared with B. fulvopicta gen. et sp. nov., B. planicollis comb. nov., B. decora comb. nov. and $B$. tenebrosa gen. et sp. nov.

\section{Remarks}

This species is redescribed based only on the holotype specimen. Originally, five paratype specimens were associated with the holotype from the same area. Closer examination of these specimens showed that they are not conspecific. We here treat these specimens as the two newly described species $B$. fulvopicta gen. et sp. nov. and B. tenebrosa gen. et sp. nov., and also as B. decora comb. nov. Breviphysoderes hobbyi comb. nov. is removed from Physoderes here and transferred to the new genus because it possesses its synapomorphies (semicircular parascutellar lobes, males do not possess an inflated anterior pronotal lobe and have prominent setigerous tubercles on the dorsal ridges of the anterior pronotal lobe). The specimen was collected by B.M. Hobby and A.W. Moore during the Oxford University Expedition in 1932. 
Breviphysoderes mjoebergi (Miller, 1940), comb. nov.

Figs 4-9; Appendix

Physoderes mjoebergi Miller, 1940: 547, fig. 90.

Physoderes dyak Miller, 1955b: 59, fig. 4. New synonymy.

\section{Diagnosis}

Recognized among species of Breviphysoderes gen. nov. by the smaller size, the head and anterior pronotal lobe being distinctly covered with dense, short, curved, setigerous tubercles, the deeply defined pronotal paramedian carina, the slightly elevated and setose posterior margin of the connexivum and the ductifer having a sclerotized elongate ring. This species is most similar to B. vestita comb. nov. but can be differentiated by its smaller size, the lack of an inflated anterior pronotal lobe in males, the hemelytron not surpassing the tip of the abdomen, and the slightly undulating (vs angularly hooked), sclerotized, flap-like prolongations of the phallosoma.

\section{Material examined}

\section{Holotype}

MALAYSIA: , Sarawak, Mt Poi (Mt Pueh), $1.8^{\circ} \mathrm{N}, 109.68333^{\circ}$ E, $610 \mathrm{~m}$, no date provided, E. Mjöberg leg. (UCR_ENT 00018536)(BMNH).

\section{Other material}

INDONESIA: Borneo: 1 o, Melawi, $0.08333^{\circ} \mathrm{N}, 111.48333^{\circ} \mathrm{E}, 43 \mathrm{~m}$, Nov-Dec. 1924, A. Blanchemanche leg. (UCR_ENT 00014059) (RMNH); 1 , Central Borneo, Malinau, Long Nawang, $0.085^{\circ} \mathrm{N}$, $114.48305^{\circ} \mathrm{E}, 762 \mathrm{~m}, 1925$, Mjöberg leg., paratype of Physoderes dyak (junior synonym) (UCR ENT 00018530) (BMNH); $1 \hat{\jmath}$, same collection data as preceding, holotype of Physoders dyak (junior synonym), MacGillavry Collection (ZMAN, ZMA.INS.834307). - Java: 1 ô, Batoerraden

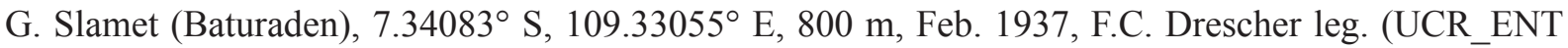
00014060) $(\mathrm{RMNH}) ; 1$ o, $7.61444^{\circ} \mathrm{S}, 110.71222^{\circ} \mathrm{E}$, no date provided, Horsfield leg. (UCR_ENT

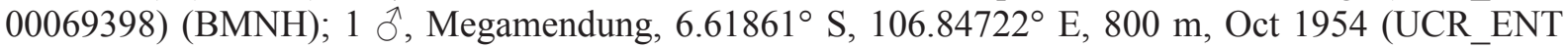
00073851) (NMPC). - Sumatra: 1 \%, Sumatera Barat (West Sumatra), Gunung Singgalang, $0.39078^{\circ}$ S, $100.35682^{\circ}$ E, $1800 \mathrm{~m}, 1926$, E. Jacobson leg. (UCR_ENT 00024039) (RMNH); 1 o, Padang, $1^{\circ} \mathrm{S}$, $100.5^{\circ} \mathrm{E}$, no date provided, Schouteden leg. (UCR_ENT 00037371) (ISNB).

MALAYSIA: 1 ㅇ, Sabah, 1 km S of Kundasang, 5.33944 N, $116.57638^{\circ}$ E, 1530 m, 27 Aug. 1983, G.F. Hevel and W.E. Steiner leg. (UCR_ENT 00030981) (USNM); 1 ô, Sarawak, Mulu National Park, near Base Camp, 4th Division Gn. [= Garrison?], 3.97444 N, $114.93638^{\circ}$ E, 100 m, May-Aug. 1978, P.M. Hammond and J.E. Marshall leg. (UCR_ENT 00069399) (BMNH).

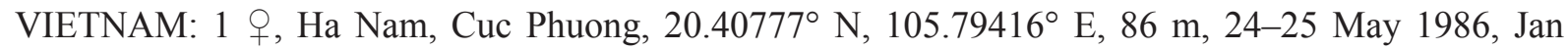
Horak leg. (UCR_ENT 00073849) (NMPC); 3 $\widehat{\jmath}$, Vinh Phuc, Tam Dao Co., Tam Dao National Park, $21.50694^{\circ} \mathrm{N}, 105.61527^{\circ} \mathrm{E}, 145 \mathrm{~m}, 6$ Sep. 2009, T. Ishikawa leg. (UCR_ENT 00052181, UCR_ENT 00073392, UCR_ENT 00077822)(UCR).

\section{Redescription}

\section{Male}

Body Length. Small-medium size, total length $7.91 \mathrm{~mm}, \mathrm{SD} \pm 1.62$ (Appendix).

Coloration (Figs 4-5). Straw-colored with dark brown patterns. Head straw-colored to light brown with dark brown suffusion. Scape and pedicel of antenna straw-colored to light brown, with slight apical darkening, basiflagellomere distinctly darker than scape and pedicel, light brown to dark brown, 
distiflagellomere straw-colored to light brown with base dark brown. First segment of labium strawcolored to brown, second segment basally and apically dark brown, medially straw-colored or light brown, third segment dark brown. Anterior lobe of pronotum dark brown with straw-colored ridges, posterior lobe straw-colored or light brown, scutellum basally dark brown, progressively lightening towards a straw-colored apex, pleuron straw-colored with dark brown suffusion, sternum straw-colored with dark brown suffusion. Corium of hemelytron straw-colored or light brown, membrane dark brown. Femora of legs straw-colored with medial and apical dark brown annulations, tibiae straw-colored with basal, medial and apical dark brown annulations, tarsi and claws straw-colored. Abdomen dorsally yellowish-orange, ventrally brown with straw-colored lateral margins, sub-lateral and medial spots, and dark brown sub-lateral suffusion, anterior half of connexivum dark brown and posterior half strawcolored, with the color proportions slightly variable, exposed part of pygophore straw-colored.

Vestiture. Densely setose. Head with widespread curved, setigerous tubercles, ventral surface of postocular lobe with sparse, setigerous tubercles, without pair of long, straight setae on postocular lobe posterior to ocelli. Anterior lobe of thorax with tuberculated, short, curved setae on lateral margins and along dorsal ridges, posterior lobe with short, curved, setigerous tubercles along lateral margins and sparsely distributed on dorsal surface. Corium of hemelytron with short, curved setae. Legs with two rows of spines and setigerous tubercles, tibiae with regular rows of tuberculated, stout, sharp setae. Posterior margin of connexivum with short, curved setae.

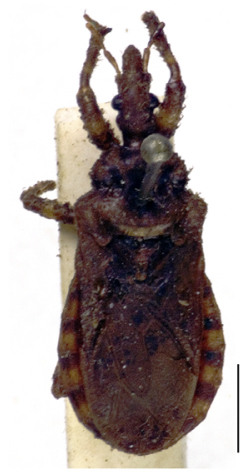

P. ostenta type of Junior Synonym UCR_ENT 00018522

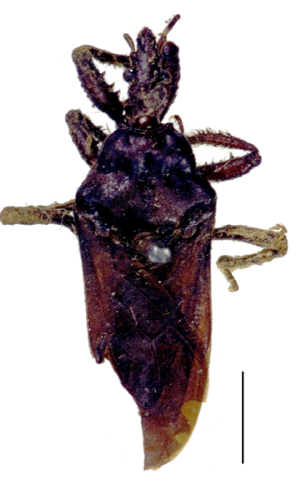

P. sibauana Holotype of Junior Synonym UCR_ENT 00018516
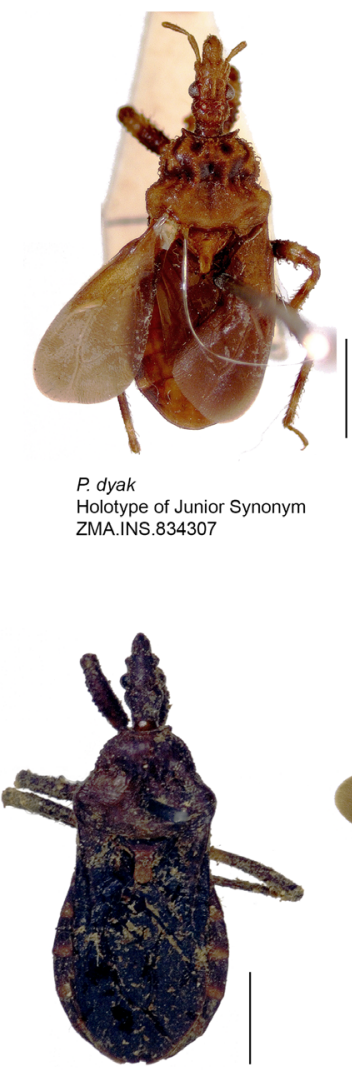

P. trusana Holotype of Junior Synonym UCR_ENT 00018515

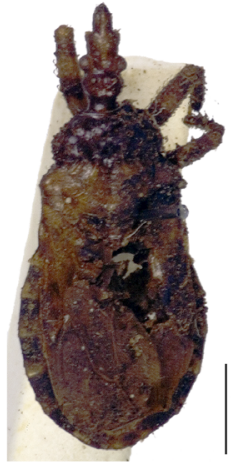

P. javanica Holotype of Junior Synonym UCR_ENT 00018537

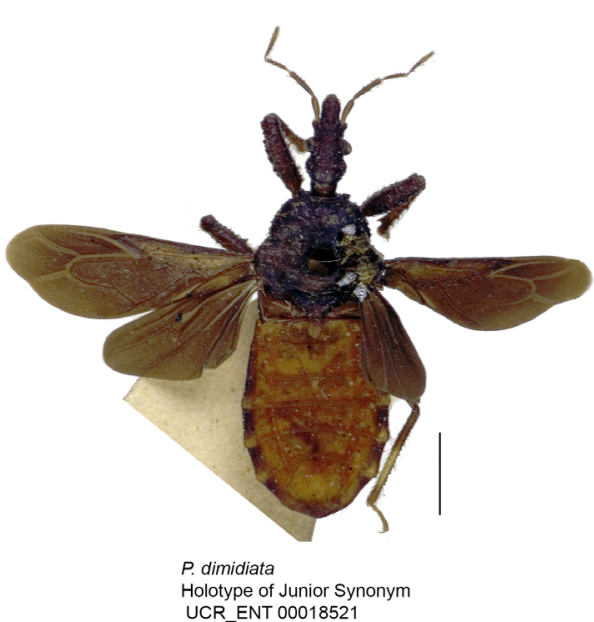

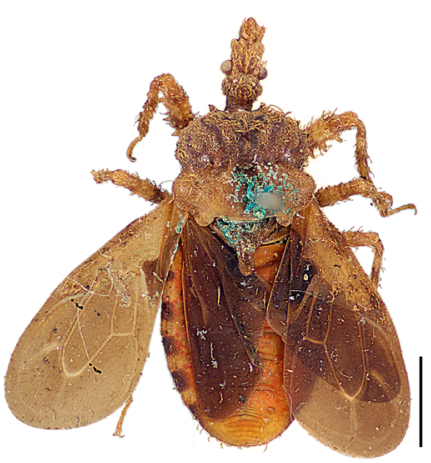

P. rugosa Holotype of Junior Synonym UCR_ENT 00023948

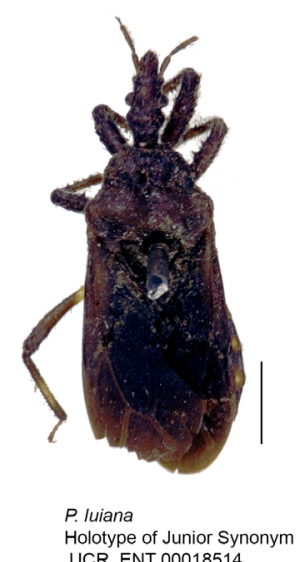

Fig. 7. Dorsal habitus images for junior synonym holotypes of species in Breviphysoderes gen. nov. and Macrophysoderes gen. nov. Scale bars $=2 \mathrm{~mm}$. 
HEAD. Scape surpassing apex of clypeus; eye distinctly projecting in dorsal view, about $1 / 5$ length of head, not attaining ventral margin of head in lateral view.

THorax. Antero-lateral paired projections acute, diverging; median pronotal depression contiguous with transverse sulcus; paramedian carina strongly defined; scutellar process long, with rounded apex; mesosternite obscured.

Hemelytron. Attaining tip of abdomen.

Legs. Same as genus description.

AbDomen. Elongate ovoid, with rounded apical margin; posterior margin slightly elevated.

GeNiTALIA. Anterior margin of mediosternite 8 sharply emarginate, without medial apodeme; apex of dorsal phallothecal sclerite subacute, with narrow lateral band-like prolongations, oriented diagonally and undulating.

\section{Female}

Similar in shape and coloration as males, but some individuals slightly larger.

\section{Ecology}

Unknown.

\section{Distribution}

Vietnam, Borneo and Java. This species has a relatively wide distribution, with specimens collected from northern Vietnam and Java, which are near the northern- and southern-most limits of the distribution of Oriental physoderine species.

\section{Remarks}

Originally described as Physoderes mjoebergi by Miller (1940), this species is transferred to Breviphysoderes gen. nov. based on the phylogenetic analysis conducted above. It is most closely related to B. vestita (Horváth, 1900) comb. nov. and both species are found on the island of Java. The two female specimens from Vietnam are slightly larger than those from Borneo and Java, but do not have any differential morphological characters and are thus identified as conspecifics. Physoderes dyak (Miller, $1955 \mathrm{~b}$ ) is synonymized here with $B$. mjoebergi comb. nov. based on the examination of one paratype at $\mathrm{BMNH}$ together with the holotype of B. mjoebergi comb. nov. No diagnostic characters were found to separate the two species based on the examination of these two specimens. Conspecificity was further confirmed by examination of habitus images of the $P$. dyak holotype at the ZMAN.

\section{Breviphysoderes planicollis (Miller, 1940), comb. nov.}

Figs 4-6; Appendix

Physoderes planicollis Miller, 1940: 547, fig. 90.

\section{Diagnosis}

This species is recognized among species of Breviphysoderes gen. nov. by having the anterior pronotal lobe distinctly covered with dense, short, curved, setigerous tubercles, the deeply defined pronotal paramedian carina, the hemelytron surpassing the tip of the abdomen, and the smooth (not undulating) connexivum. This species is most similar to $B$. hobbyi comb. nov., B. decora comb. nov. and B. fulvopicta gen. et sp. nov. It can be differentiated from $B$. hobbyi comb. nov. by the overall lighter coloration, 
especially the color pattern of the anterior pronotal lobe, and the shorter external cell of the hemelytron (framed by the cubital and medial veins). It differs from B. decora comb. nov. and B. flavopicta gen. et sp. nov. by having its hemelytron extending beyond the tip of the abdomen, while the apex of the scutellar process and the apex of the external cell of the hemelytron lack the prominent straw color.

\section{Material examined}

\section{Holotype}

MALAYSIA: ${ }^{\wedge}$, Sarawak, Mt Dulit, $3.33305^{\circ} \mathrm{N}, 114.14972^{\circ} \mathrm{E}, 886 \mathrm{~m}$, no date provided, E. Mjöberg leg. (UCR_ENT 00018535) (BMNH).

\section{Redescription}

Male

Body Length. Medium size, total length $9.8 \mathrm{~mm}$.

COLORATION (Figs 4-5). Light brown with dark brown patterns. Head brown with dark brown suffusion. Scape of antenna straw-colored with brown apex, pedicel brown with straw brown apex, basi- and distiflagellomeres missing. First segment of labium brown, second segment basally and apically dark brown, medially light brown, third segment dark brown. Anterior lobe of pronotum dark brown with straw-colored patterns, posterior lobe straw brown, scutellum dark brown with brown apex, pleuron light brown with dark brown suffusion, sternum brown with dark brown suffusion. Corium of hemelytron straw-colored to brown, membrane straw brown to brown, slightly translucent. Femora of legs strawcolored with medial and apical light brown annulations, tibiae straw-colored with basal, medial and apical light brown annulations, tarsi and claws straw-colored. Abdomen dorsally yellowish-orange, ventrally brown with dark brown lateral suffusion.

Vestiture. Densely setose. Head with widespread curved, setigerous tubercles, ventral surface of postocular lobe with sparse, setigerous tubercles, without pair of long, straight setae on postocular lobe posterior to ocelli. Anterior lobe of thorax with tuberculated, short, curved setae on lateral margins and along dorsal ridges, posterior lobe with short, curved, setigerous tubercles along lateral margins and sparsely distributed on dorsal surface. Corium of hemelytron with short, curved setae. Legs with two rows of spines and setigerous tubercles, tibia with regular rows of tuberculated, stout, sharp setae. Posterior margin of connexivum with short, curved setae.

HEAD. Scape surpassing apex of clypeus; eye distinctly projecting in dorsal view, less than $1 / 5$ length of head, not attaining ventral margin of head in lateral view.

Thorax. Antero-lateral paired projections acute, diverging; median pronotal depression contiguous with transverse sulcus; paramedian carina strongly defined; scutellar process long with rounded apex; mesosternite with irregular, tuberculated median protrusion between fore and mid coxae.

HeMELYTRON. Surpassing tip of abdomen.

LeGs. Same as genus description.

ABDOMEN. Elongate ovoid, with straight terminal margin; connexival margin smooth, not undulating, posterior margin slightly elevated.

GENITALIA. Previously dissected and genitalia missing.

\section{Female}

Unknown. 


\section{Ecology}

Nothing is known about the biology of this species.

\section{Distribution}

This species is only known from the type locality of Mt Dulit in Sarawak, north-central Borneo. The type locality is shared with $B$. fulvopicta gen. et sp. nov., B. hobbyi comb. nov., B. decora comb. nov. and $B$. tenebrosa gen. et sp. nov.

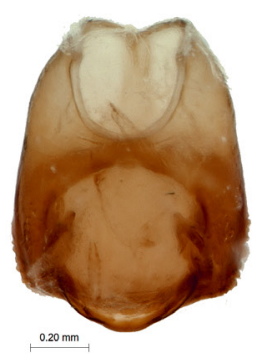

B. mjoebergi comb. nov. UCR_ENT 00073851

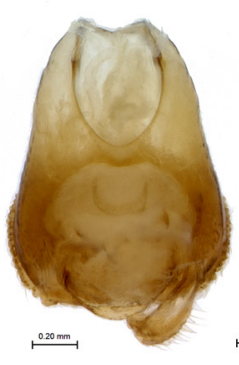
M. grandis sp. nov.
Holotype UCR_ENT 00052314

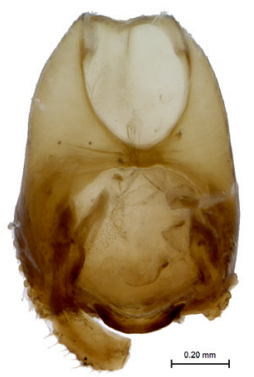

P. brevipennis sp. nov. Paratype UCR_ENT 00069376
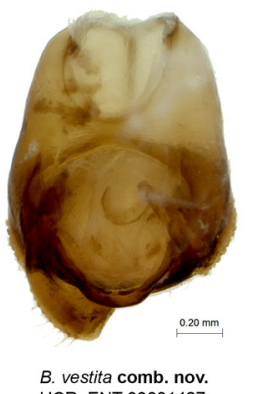
B. vestita comb. nov.
UCR_ENT 00031427

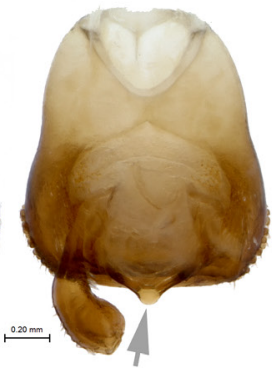

M. modesta comb. nov. UCR_ENT 00069386

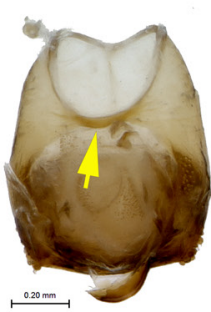
P. curculionis
UCR ENT 00031401

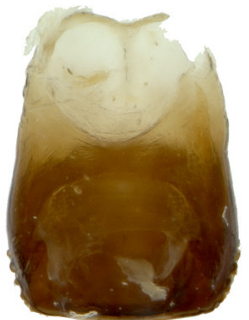

$0.20 \mathrm{~mm}$

P. nigripennis sp. nov.
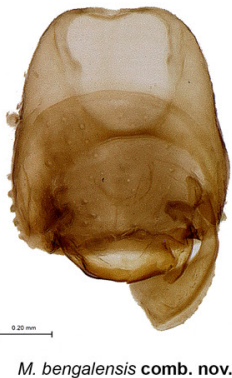
M. bengalensis comb
UCR_ENT 00069412
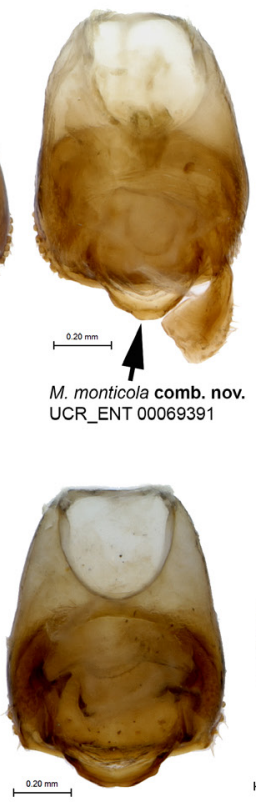
P. fuliginosa
UCR_ENT 00031331

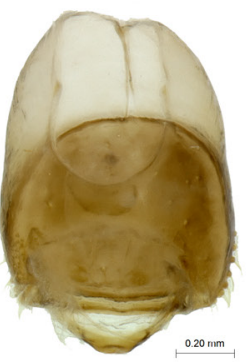

P. notata
UCR_ENT 00024056

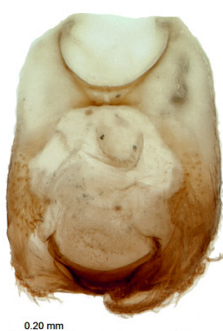

$0.20 \mathrm{~mm}$

M. cirripilosa sp. nov. UCR_ENT 00073459
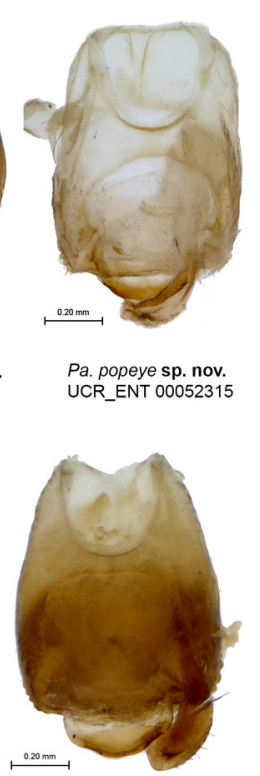

P. minime sp. nov.
Paratype UCR_ENT 00031433
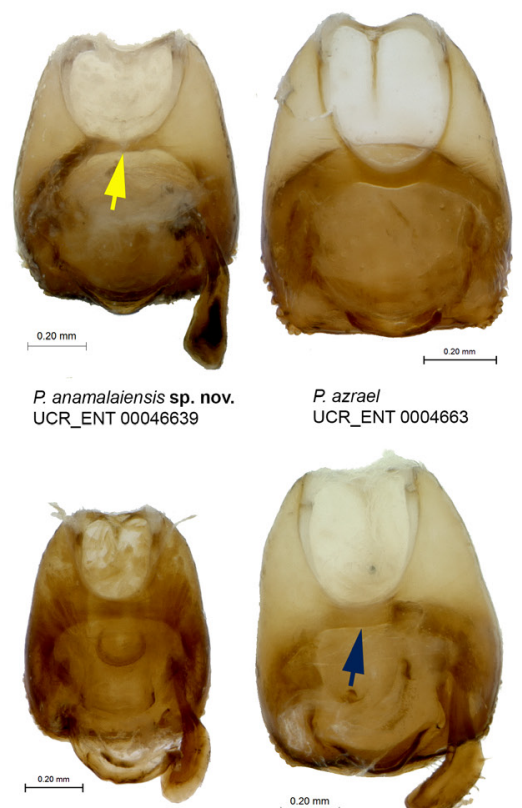

P. muluensis sp. nov.

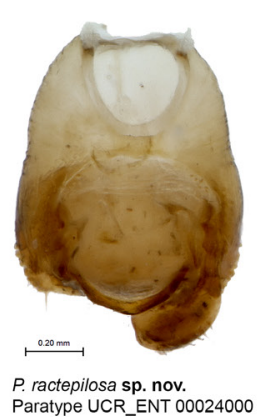

UCR_ENT 0004663

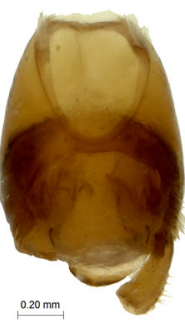

M. elongata sp. nov. UCR_ENT 00073583

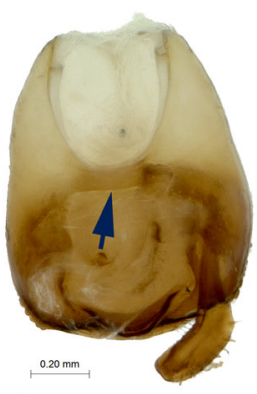

P. mysorensis sp. nov. P. mysorensis sp. nov.

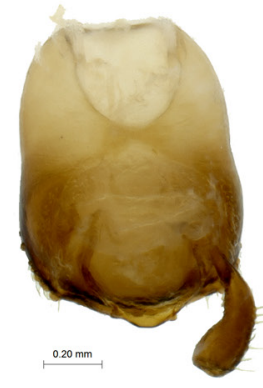

P. tricolor sp. nov. Paratype UCR_ENT 00031439

Fig. 8. Dorsal view of the male pygophore in species of Breviphysoderes gen. nov., Macrophysoderes gen. nov., Paraphysoderes Villiers, 1962 and Physoderes Westwood, 1845. For an explanation of the colored arrows, see keys on pages 37 and 66. 


\section{Remarks}

This species is redescribed based on the holotype specimen. Miller (1940) recognized this specimen as a species different from B. hobbyi (Miller, 1940) comb. nov. due to the different anterior pronotal lobe coloration. Breviphysoderes planicollis comb. nov. is removed from Physoderes and transferred to this genus because it shares its synapomorphies (parascutellar lobes are semicircular, the male specimen does not possess an inflated anterior pronotal lobe and has prominent setigerous tubercles on the dorsal ridges of the anterior pronotal lobe). The specimen was collected by Dr E. Mjöberg during the Kalabit Expedition. The darkened scutellum and overlapping distribution, shared with $B$. hobbyi comb. nov., $B$. decora comb. nov. and B. tenebrosa gen. et sp. nov., suggest that they are likely to be closely related.

Breviphysoderes shelfordi (Miller, 1940), comb. nov.

Figs 4, 6; Appendix

Physoderes shelfordi Miller, 1940: 551, fig. 91.

\section{Diagnosis}

This species is recognized among other species of Breviphysoderes gen. nov. by the scape surpassing the apex of the clypeus, the antero-lateral pronotal projection oriented anteriorly, the deeply defined pronotal paramedian carina, the distinct straw-colored mark on the apical veins of the external cell of the hemelytron $(\mathrm{Cu}+\mathrm{M})$ and hemelytron surpassing the tip of the abdomen. It is most similar to $B$. hobbyi comb. nov. and $B$. planicollis comb. nov. It can be differentiated from $B$. tenebrosa gen. et sp. nov. by the overall coloration and a narrower postocular lobe. It differs from B. planicollis comb. nov. by the orientation of the antero-lateral pronotal projection and the straw-colored mark on the apical veins of the external cell.

\section{Material examined}

\section{Holotype}

MALAYSIA: ${ }^{\Uparrow}$, Sarawak, Kuching, Capt. [= Capital?], $1.53055^{\circ}$ N, $110.34388^{\circ}$ E, 12 m, 14 Aug. 1899 , Dyak Collection (UCR_ENT 00018538) (BMNH).

\section{Redescription}

\section{Male}

Body LENGTH. Medium, total length $9 \mathrm{~mm}$.

Coloration (Fig. 4). Light brown with dark brown patterns. Head light brown to dark brown. Scape of antenna straw-colored with light brown apex, basal half of pedicel straw-colored and apical half brown, basi- and distiflagellomeres missing. Labium light brown. Pronotum dark brown with brown suffusion, scutellum dark brown with light brown apex. Corium of hemelytron brown, membrane brown with apical veins of external cell $(\mathrm{Cu}+\mathrm{M})$ straw-colored. Femora of legs light brown with medial and apical dark brown annulations, tibiae brown with basal, medial and apical dark brown annulations, tarsi and claws light-brown or brown. Abdomen not examined dorsally, ventrally light brown medially with lateral brown suffusion, anterior half of connexivum dark brown and posterior half straw-colored.

Vestiture. Sparsely setose. Head with some flat, curved setae, without pair of long, straight setae on postocular lobe posterior to ocelli. Anterior lobe of thorax with tuberculated, short, curved setae on lateral margins and along dorsal ridges, posterior lobe with short, curved, setigerous tubercles along lateral margins and sparsely distributed on dorsal surface. Corium of hemelytron with short, curved setae. Legs with two rows of spines and setigerous tubercles, tibiae with regular rows of tuberculated, stout, sharp setae. Posterior margin of connexivum with short, curved setae. 
HEAD. Scape surpassing apex of clypeus; eye distinctly projecting in dorsal view, about $1 / 5$ length of head, not attaining ventral margin of head in lateral view.

THorax. Antero-lateral paired projections acute; median pronotal depression contiguous with transverse sulcus; paramedian carina strongly defined; posterior lobe medially rugose (damaged/obscured medially by pin); scutellar process long, with rounded apex; mesosternite obscured.

Hemelytron. Surpassing tip of abdomen.

Legs. Same as genus description.

AвDomen. Elongate ovoid, with rounded terminal margin; connexival margin slightly undulating, posterior margin slightly elevated.

Genitalia. Not examined.

\section{Female}

Unknown.

\section{Ecology}

Nothing is known about the biology of this species.

\section{Distribution}

This species is only known from the type locality in north-western Borneo, Kuching.

\section{Remarks}

This species is redescribed based on the holotype specimen. Breviphysoderes shelfordi comb. nov. is removed from Physoderes and transferred to Breviphysoderes gen. nov. because it possesses the synapomorphies of this genus (parascutellar lobes are semicircular, males do not possess an inflated anterior pronotal lobe and have prominent setigerous tubercles on the dorsal ridges of the anterior pronotal lobe). This species is quite similar to other members of the genus found in Sarawak, Borneo, but is recognized as a separate species based on the diagnostic characters listed above. More specimens from this area will be needed to further test the status of these closely related species.

\section{Breviphysoderes tenebrosa gen. et sp. nov. urn:1sid:zoobank.org:act:4F15C5ED-7294-44F1-9FBE-C3755EFE69D3}

Figs 4-6; Appendix

\section{Diagnosis}

This species is recognized among other species of Breviphysoderes gen. nov. by the entirely brownishblack coloration, the antero-lateral pronotal projection oriented anteriorly, the pronotal paramedian carina being deeply defined and the hemelytron surpassing the tip of the abdomen. This species is most similar to B. hobbyi comb. nov. and B. planicollis comb. nov. It can be differentiated from both species by the overall coloration, the orientation of the antero-lateral pronotal projection and the shape of the external cell.

\section{Etymology}

The name tenebrosa is selected after the Latin adjective for "tenebrosus", meaning dark, to describe the distinctive brownish-black coloration of the specimen. 


\section{Material examined}

\section{Holotype}

MALAYSIA: $\hat{\sigma}$, Sarawak, foot of Mt Dulit, junction of Rivers Tinjar and Lejok, $3.32388^{\circ} \mathrm{N}$, $114.14722^{\circ}$ E, 730 m, 24 Aug. 1932, B.M. Hobby and A.W. Moore leg. (UCR_ENT 00018489) (BMNH).

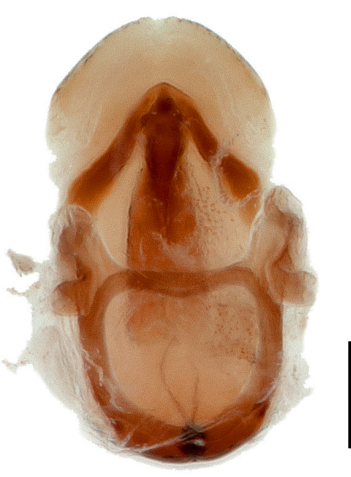

B. mjoebergi comb. nov. UCR_ENT 00073851

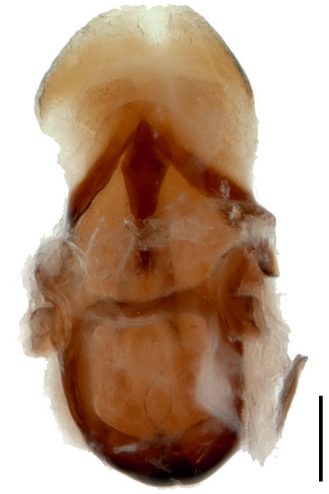

B. vestita comb. nov. UCR_ENT 00031427

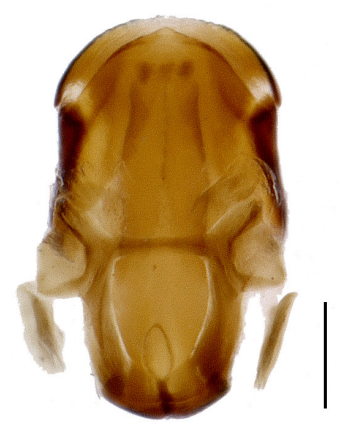

M. bengalensis comb. nov. UCR_ENT 00069412

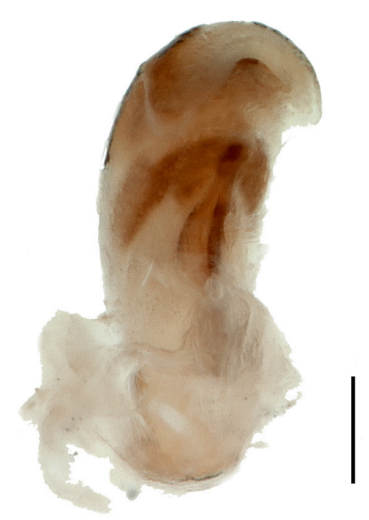

M. cirripilosa sp. nov. UCR_ENT 00073459

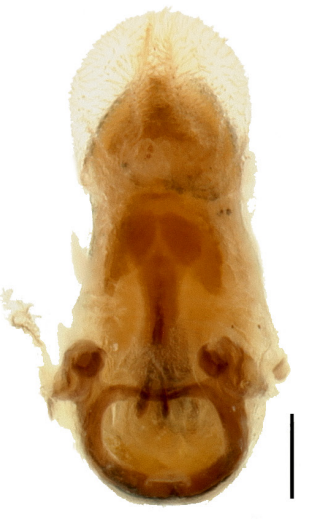

M. elongata sp. nov. UCR_ENT 00073583

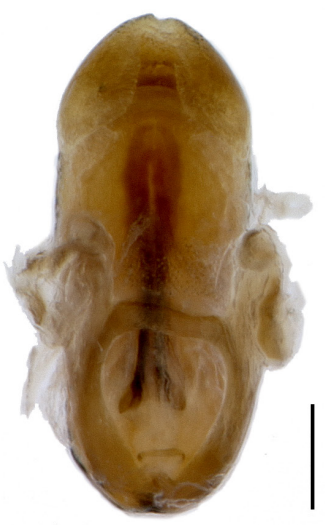

M. finisterre sp. nov. UCR_ENT 00069282

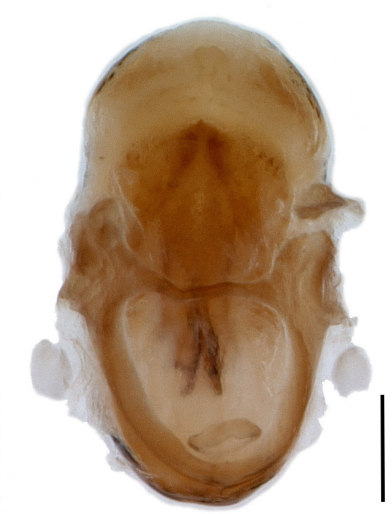

M. grandis sp. nov. Holotype UCR_ENT 00052314

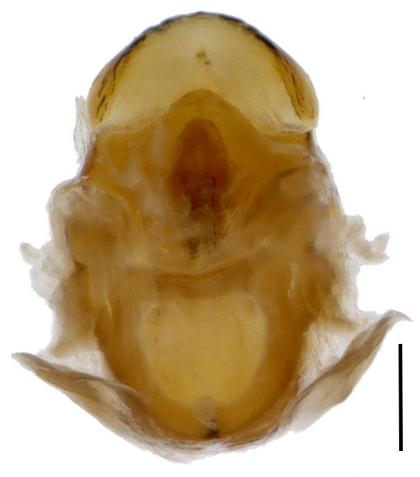

M. modesta comb. nov. UCR_ENT 00069386

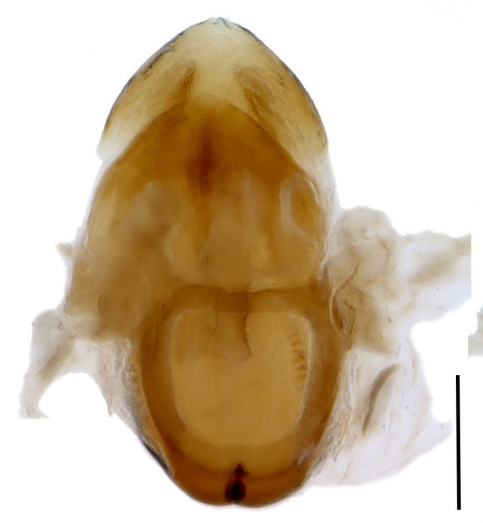

M. monticola comb. nov. UCR_ENT 00069391

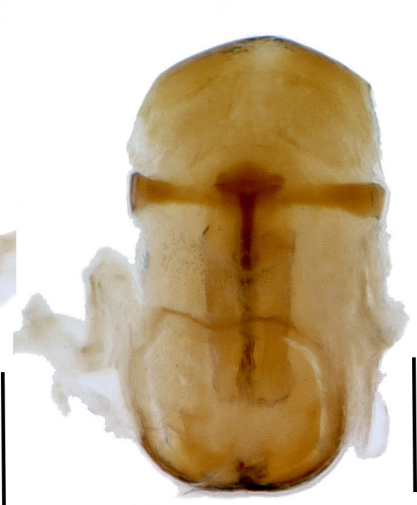

Pa. popeye sp. nov. UCR_ENT 00052315

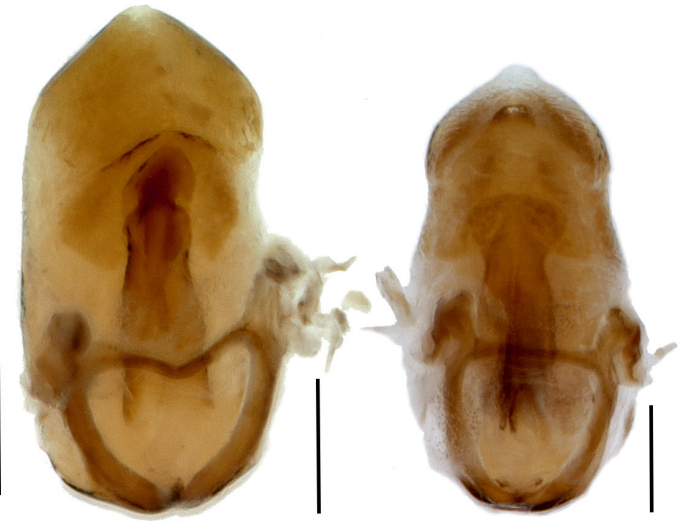

$P$. anamalaiensis sp. nov. UCR_ENT 00046639
P. azrael UCR_ENT 0004663

Fig. 9. Dorsal view of the phallus in species of Breviphysoderes gen. nov., Macrophysoderes gen. nov., Paraphysoderes Villiers, 1962 and Physoderes Westwood, 1845 (partial). Scale bars $=0.20 \mathrm{~mm}$. 


\section{Description}

Male

Body LENGTH. Small size, total length $7.07 \mathrm{~mm}$.

Coloration (Figs 4-5). Entirely brownish-black. Antenna missing. Forelegs missing, mid- and hindlegs brownish black.

Vestiture. Densely setose. Head with widespread curved, setigerous tubercles, ventral surface of postocular lobe with sparse, setigerous tubercles, without pair of long, straight setae on postocular lobe posterior to ocelli. Anterior lobe of thorax with tuberculated, short, curved setae on lateral margins and along dorsal ridges, posterior lobe with short, curved, setigerous tubercles along lateral margins and sparsely distributed on dorsal surface. Corium of hemelytron with short, curved setae. Tibiae with regular rows of tuberculated, stout, sharp setae. Posterior margin of connexivum with short, curved setae.

HEAD. Eye distinctly projecting in dorsal view, about $1 / 5$ length of head, not attaining ventral margin of head in lateral view.

Thorax. Antero-lateral paired projections acute, oriented anteriorly; median pronotal depression contiguous with transverse sulcus; paramedian carina strongly defined (posterior lobe damaged/obscured medially by pin); scutellar process long, with rounded apex; mesosternite with median, irregular, tuberculated protrusion between fore and mid coxae.

HeMELYTRON. Surpassing tip of abdomen.

ABDomen. Elongate ovoid, with rounded terminal margin; connexival margin slightly undulating, posterior margin not elevated.

Genitalia. Not examined.

\section{Female}

Unknown.

\section{Ecology}

The type specimen was found on the bark of a felled tree along the junction of two rivers.

\section{Distribution}

This species is only known from the type locality of Mt Dulit in Sarawak, north-central Borneo. The type locality is shared with B. fulvopicta gen. et sp. nov., B. planicollis comb. nov., B. decora comb. nov. and $B$. hobbyi comb. nov.

\section{Remarks}

This species is described based on a single specimen originally designated as a paratype of $B$. hobbyi (Miller, 1940) comb. nov. Even though it shares the collecting event and locality with specimens of that species, closer examination showed distinct morphological differences and we describe this specimen as a separate species. It was collected by B.M. Hobby and A.W. Moore during the Oxford University Expedition in 1932. 
Breviphysoderes vestita (Horváth, 1900), comb. nov.

Figs 4-9; Appendix

Epirodera vestita Horváth, 1900: 639.

Physoderes serraticollis Breddin, 1903: 125. New synonymy.

Physoderes javanica Miller, 1940: 549, fig. 91. New synonymy.

Physoderes rugosa Miller, 1954: 87, fig.11. New synonymy.

Physoderes vestita - Maldonado 1990: 381.

\section{Diagnosis}

This species is recognized among species of Breviphysoderes gen. nov. by having the head and anterior pronotal lobe distinctly covered with dense, short, curved, setigerous tubercles, the scape surpassing the apex of the clypeus, males with the anterior pronotal lobe almost as wide as the posterior pronotal lobe, the apical veins of the external cell of the hemelytron $(\mathrm{Cu}+\mathrm{M})$ with distinct straw-colored marks, and the hemelytron surpassing the tip of the abdomen. This species most closely resembles B. fulvopicta gen. et sp. nov. but is differentiated by the wider anterior pronotal lobe in males and the length of the hemelytron (i.e., surpassing the tip of the abdomen).

\section{Material examined}

\section{Holotype}

INDONESIA: $\widehat{\gamma}$, East Java, Tjibodas (Cibodas), $6.97527^{\circ} \mathrm{S}, 107.6625^{\circ} \mathrm{E}, 614 \mathrm{~m}$, no date provided, R. Semon leg. (UCR_ENT 00012260) (HNHM).

\section{Other material}

INDONESIA: Java: 2 우, E Java, Nongkodjadjar (Nonkojajar), $7.91611^{\circ} \mathrm{S}, 112.8875^{\circ} \mathrm{E}, 846 \mathrm{~m}, 1911$, E. Jacobson leg. (UCR_ENT 00024050, UCR_ENT 00014054) (RMNH); 1 q, Buitenzorg (Bogor), $6.6875^{\circ} \mathrm{S}, 106.81472^{\circ} \mathrm{E}, 447 \mathrm{~m}$, Mar. 1909, Bryant and Palmer leg. (UCR_ENT 00068910) (AMNH); $1 \overbrace{}^{\top}$, Gunung Boerangrang (Burangrang), $6.775^{\circ} \mathrm{S}, 107.55555^{\circ} \mathrm{E}, 1600 \mathrm{~m}$, Dec. 1936, F.C. Drescher leg. (UCR_ENT 00024043) (RMNH); 1 \%, Gunung Malabar, 7.13 ${ }^{\circ} \mathrm{S}, 107.65^{\circ} \mathrm{E}, 1600 \mathrm{~m}$, Jun. 1936, F.C. Drescher leg. (UCR_ENT 00024038) (RMNH); 1 + , 7.61444 ${ }^{\circ} \mathrm{S}, 110.71222^{\circ} \mathrm{E}$, no date provided, Muller leg. (UCR_ENT 00024049) (RMNH); 1 o, unknown date, holotype of Physoderes javanica (junior synonym) (UCR_ENT 00018537) $(\mathrm{BMNH}) ; 1$ q, 7.61444 ${ }^{\circ} \mathrm{S}, 110.71222^{\circ} \mathrm{E}, 1000 \mathrm{~m}$, Dec. 1951, L.G.E. Kalshoven leg. (UCR_ENT 00024040) (RMNH); 1 §o, Lembang, W Java, $6.82166^{\circ} \mathrm{S}$, $107.63^{\circ}$ E, 1259 m, 1921, L.G.E. Kalshoven leg. (UCR_ENT 00024061) (RMNH); 1 क, Megamedg Mountains, $6.61861^{\circ} \mathrm{S}, 106.84722^{\circ} \mathrm{E}, 1280 \mathrm{~m}$, no date provided, Bryant and Palmer leg. (UCR_ENT

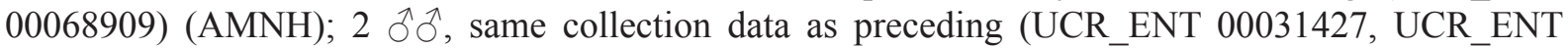
00031428) (USNM); 1 \% , Mt Patoeha, 7.16138 ${ }^{\circ}$ S, $107.39972^{\circ}$ E, 1550 m, Mar. 1937, E. Jacobson leg. (UCR_ENT 00024037) (RMNH); 1 đ, Tangkuban Perahu (Tangkoeban Prahoe) volcano, 4000-5000 ft, $6.76305^{\circ} \mathrm{S}, 107.59944^{\circ} \mathrm{E}, 1955 \mathrm{~m}$, Nov. 1936, F.C. Drescher leg. (UCR_ENT 00024042) (RMNH); 1 q, same locality as preceding, Mar. 1937, F.C. Drescher leg. (UCR_ENT 00024036) (RMNH); 6 우, same locality as preceding, Feb. 1937, F.C. Drescher (UCR_ENT 00024034, UCR_ENT 00024035, UCR_ENT 00024045-UCR_ENT 00024048) (RMNH); 1 q, W Java, Tjisaroea (Cisarua), $6.78916^{\circ} \mathrm{S}$, $107.535^{\circ}$ E, $1000 \mathrm{~m}, 11 \mathrm{Jan} .1931$, collector unknown (UCR_ENT 00024041) (RMNH); 1 + , 14 Dec. 1928, L.G.E. Kalshoven leg., holotype of Physoderes rugosa (junior synonym) (UCR_ENT 00023948)

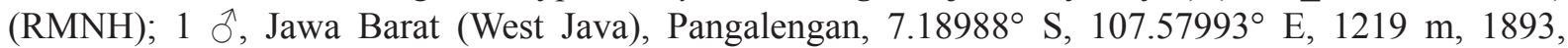
H. Fruhstorfer leg., holotype of Physoderes serraticollis (junior synonym) (UCR_ENT 00040567) (DEI); 1 §, unlabeled specimen (UCR_ENT 00024044) (RMNH). 


\section{Redescription}

\section{Male}

Body Length. Medium-large size, total length $10.02 \mathrm{~mm}, \mathrm{SD} \pm 0.24$ (Appendix).

Coloration (Figs 4-5, 7). Straw-colored to brown with dark brown patterns. Head brown. Scape of antenna straw-colored with light brown apex, pedicel straw-colored to light brown, basiflagellomere straw-colored with light brown apex, distiflagellomere straw-colored with light brown base. First segment of labium with basal half brown, apical half straw-colored, second segment straw-colored with base and apex brown, third segment brown. Pronotum dark brown with straw-colored setae, scutellum dark brown, pleuron straw-colored to dark brown, sternum brown to dark brown. Corium of hemelytron straw-colored, membrane brown with apical veins of external cell $(\mathrm{Cu}+\mathrm{M})$ straw-colored, sometimes including medial vein apex. Femora straw-colored with medial and apical brown annulations, tibiae straw-colored with basal, medial and apical light brown annulations, tarsi and claws straw-colored. Abdomen dorsally yellowish-orange, ventrally light brown, medially with dark brown sub-lateral and posterior suffusion, anterior half of connexivum dark brown and posterior half straw-colored, exposed part of pygophore straw-colored.

Vestiture. Densely setose. Head with widespread setigerous tubercles bearing long, semi-erect, spatulate, curved setae, ventral surface of postocular lobe with sparse, setigerous tubercles, with a pair of long, straight setae on postocular lobe posterior to ocelli. Anterior lobe of thorax with tuberculated, short, curved setae on lateral margins and along dorsal ridges, posterior lobe with short, curved, setigerous tubercles along lateral margins and sparsely distributed on dorsal surface. Corium of hemelytron with short, curved setae. Legs with two rows of spines and setigerous tubercles, tibiae with regular rows of tuberculated, stout, sharp setae. Posterior margin of connexivum with short, curved setae.

HEAD. Scape surpassing apex of clypeus; eye distinctly projecting in dorsal view, about $1 / 5$ length of head, not attaining ventral margin of head in lateral view.

THORAX. Antero-lateral paired projections acute, diverging; surface of anterior lobe with raised ridges; median pronotal depression not contiguous with transverse sulcus; paramedian carina strongly defined; scutellar process long, with rounded apex; mesosternite with median irregular tuberculated protrusion between fore and mid coxae.

Hemelytron. Surpassing tip of abdomen.

LEGS. Same as genus description.

AвDOMEN. Elongate ovoid, with rounded terminal margin; connexival margin slightly undulating, posterior margin slightly elevated.

GENITALIA. Anterior margin of mediosternite 8 sharply emarginate, with medial apodeme; apex of dorsal phallothecal sclerite rounded, with narrow, lateral, band-like prolongations, oriented diagonally and angularly curved along lateral margins of phallosoma towards basal plate.

\section{Female}

Similar to males except in having a narrower anterior pronotal lobe.

\section{Ecology}

Nothing is known about the biology of this species except that specimens have been collected from mid to high altitudes ranging from $447 \mathrm{~m}$ to $1955 \mathrm{~m}$ with most specimens collected from elevations higher than $1200 \mathrm{~m}$. 


\section{Distribution}

This species is exclusively found on the island of Java (the locality for one of the examined specimens is unknown).

\section{Remarks}

Originally described as Epirodera vestita (Horváth, 1900), this species is transferred to Breviphysoderes gen. nov. based on the phylogenetic analysis conducted above. It is most similar to B. mjoebergi (Miller, 1940) comb. nov., and both species co-occur on the island of Java. Physoderes serraticollis Breddin, 1903, P. javanica Miller, 1940 and P. rugosa Miller, 1954 are here synonymized with $B$. vestita comb. nov. based on the examination of all type specimens. No diagnostic morphological characters can be found to separate these species, except that the holotype of P. javanica, which is a female, has a narrower anterior pronotal lobe. Nevertheless, this specimen possesses the raised anterior pronotal ridges with setigerous tubercles, the completely dark brown anterior pronotal lobe, the straw-colored apical veins of the external cell of the hemelytron and the rounded abdominal margin that are diagnostic for $B$. vestita comb. nov. The holotypes of both $P$. rugosa and $P$. serraticollis are males and share the broad anterior pronotal widths of $B$. vestita, which has raised ridges and dense, tuberculated, curved setae, as well as the remaining diagnostic characters. Both were also collected from Java.

\section{Macrophysoderes gen. nov. urn:1sid:zoobank.org:act:2D4195FE-B54C-42E2-B023-0EE03A15A464}

Figs 7-12; Appendix

\section{Diagnosis}

This genus is recognized among genera of Physoderinae by often having a glabrous, sparsely setose pronotum (except for M. cirripilosa gen. et sp. nov., M. elongata gen. et sp. nov. and M. finisterre gen. et sp. nov.), the eyes being very large and distinctly projecting in dorsal view and sometimes attaining the ventral margin of the head in lateral view, the anterior pronotal lobe narrower or slightly narrower than the posterior lobe, the antero-lateral pronotal projection often being truncate, but sometimes acute, and the margin of the anterior opening of the pygophore being rounded in lateral view. Macrophysoderes gen. nov. is most similar to Physoderes, but is distinguished by the very large and distinctly projecting eyes in most species, the males with the anterior pronotal lobe narrower than the posterior lobe and by the glabrous pronotum.

\section{Etymology}

The name combines Physoderes after the type genus of Physoderinae and the Greek adjective "macro" to indicate the large size of the eyes. The gender is feminine.

\section{Type species}

Physoderes modesta Miller, 1940.

\section{Description}

\section{Male}

BoDY LENGTH. Ranging from small to very large, $7.80-11.58 \mathrm{~mm}$.

Coloration (Figs 7, 10-11). Variable, from straw-colored to dark brown. Head, pronotum, legs and corium of similar lighter coloration, annulation patterns of hind femur variable, scutellum and claval region with darker coloration.

VeStiture. Glabrous or densely setose with tuberculated, curved setae. 
HEAD. Elongate or short conical; maxillary plate truncate or rounded apically; scape length variable; eye distinctly projecting in dorsal view except in $M$. elongata gen. et sp. nov., sometimes attaining ventral margin of head in lateral view; height of anteocular lobe shorter or level with postocular lobe, ocelli present.

THORAX. Antero-lateral paired pronotal projection truncate or acute, oriented anteriorly or diverging; surface of anterior lobe smooth, anterior pronotal ridges almost obsolete or low; median pronotal depression contiguous with transverse sulcus in both sexes except in M. cirripilosa gen. et sp. nov. and M. elongata gen. et sp. nov.; paramedian carina variably defined; posterior lobe medially rugose; anterior pronotal lobe equal to or shorter than posterior lobe, narrower or slightly narrower than posterior lobe in males, anterior lobe lower than or level with posterior lobe in lateral view; parascutellar lobe shape variable, either triangular, bell-shaped or rounded and skewed towards median; scutellum rounded triangular, length of scutellar process variable from very short to long, shape of apex variable; mesosternite with median, irregular, tuberculated protrusion between fore and mid coxae except in M. elongata gen. et sp. nov.

Hemelytron. Macropterous, length variable.

LEGS. Fore femur distinctly incrassate, tarsi three-segmented.

ABDOMEN. Elongate ovoid, with straight or rounded posterior margin; connexival margin smooth or slightly undulating, posterior margin not elevated.

Genitalia. Anterior margin of mediosternite 8 undulating or sharply emarginated, with or without medial apodeme; transverse bridge of pygophore of variable width, margin of anterior opening rounded or angular, apodeme present, apical margin of posterior opening smooth; cup-like sclerite apically variable; arms of basal plate converging or curved to form rounded foramen; ductifer with membranous or sclerotized ring of variable shapes; endosomal struts of variable shapes; dorsal phallothecal sclerite subacute, with lateral, broad, plate-like prolongations of variable sizes.

\section{Female}

Most often similar in size, shape and color to male except with wider abdomen.

\section{Ecology}

Not much is known about the biology. A few species are known to occur at higher elevations (1000$2000 \mathrm{~m}$ ). One specimen of $M$. cirripilosa gen. et sp. nov. was collected from a log and another from a light trap.

\section{Distribution}

This genus currently comprises 8 species and is widely distributed across Southeast Asia and Australasia, and can be found in the Bengal region, peninsular Malaysia, Borneo, New Guinea and the Solomon Islands. The highest species diversity for this genus is found on the island of New Guinea.

\section{Key to species of Macrophysoderes gen. nov.}

1. Head elongate conical, scape not reaching apex of clypeus (Fig. 10, black arrow) 2

- Head short conical, scape reaching or surpassing apex of clypeus (Fig. 10, grey arrow) .................4

2. Hind femur brown, with basal and subapical straw-colored annulations (Fig. 10, pink arrows) .. ..M. histrionica (Miller, 1940) comb. nov.

- Hind femur brown, with single basal straw-colored annulation (Fig. 10, white arrow) ..............3 


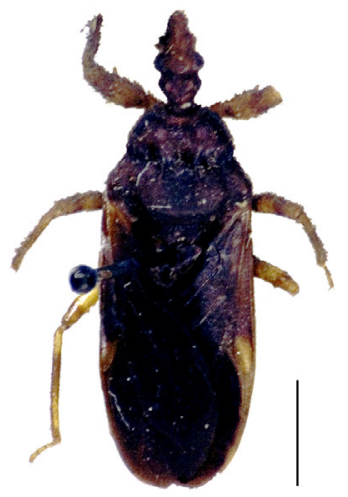

$M$. bengalensis comb. nov. Holotype UCR_ENT 00018528

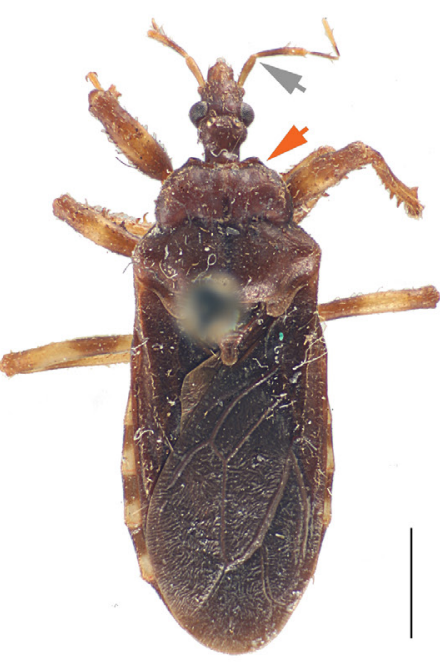

M. grandis sp. nov Holotype UCR_ENT 00052314

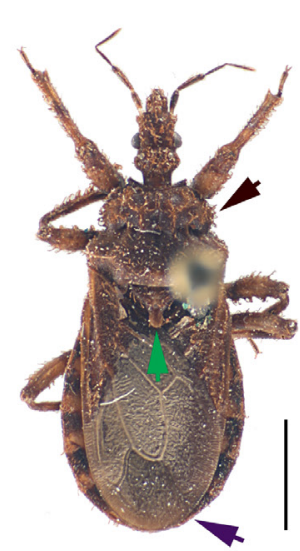

M. cirripilosa sp nov. UCR_ENT 00014057

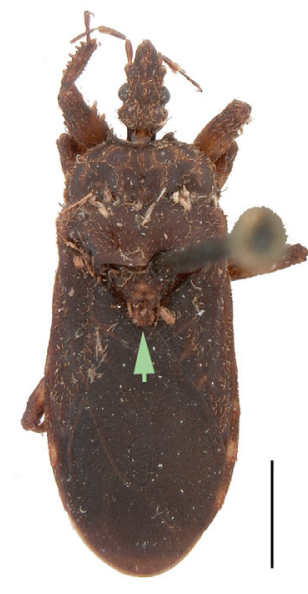

M. elongata sp. nov. Holotype UCR_ENT 00073634

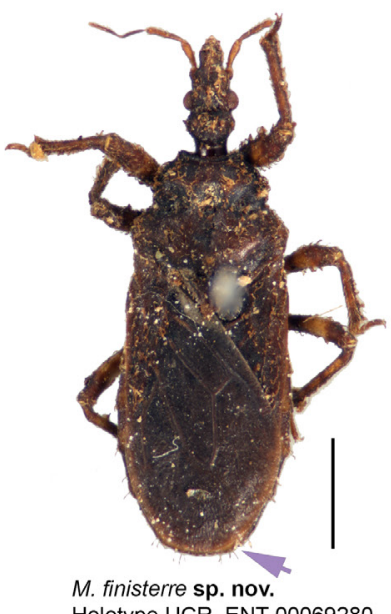

Holotype UCR_ENT 00069280

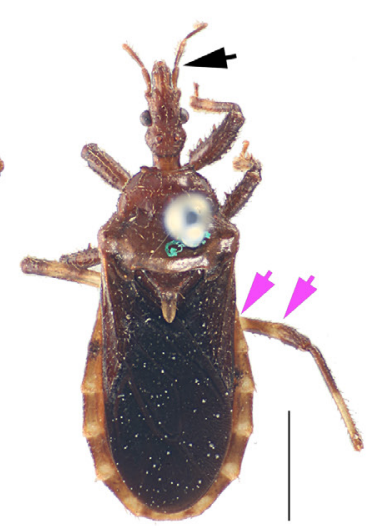

M. histrionica comb. nov. UCR_ENT 00030983

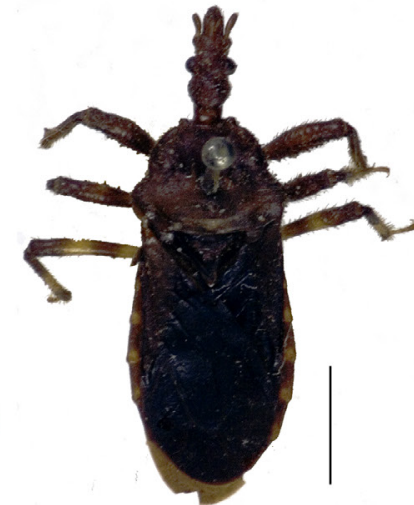

M. histrionica comb. nov. Holotype UCR_ENT 00018520

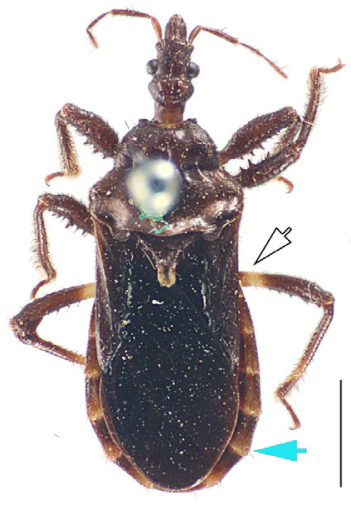

M. modesta comb. nov. UCR_ENT 00030982

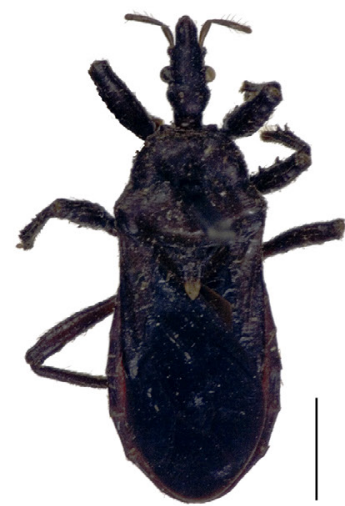

M. modesta comb. nov. Holotype UCR_ENT 00018533

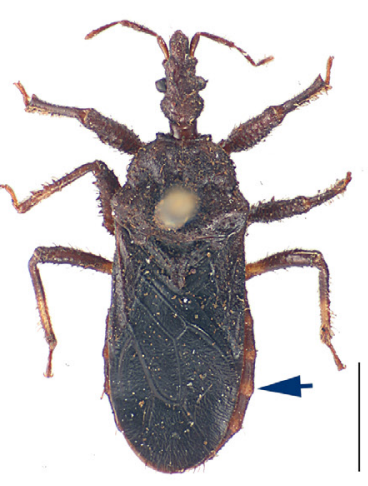

M. monticola comb. nov. UCR ENT 00052313

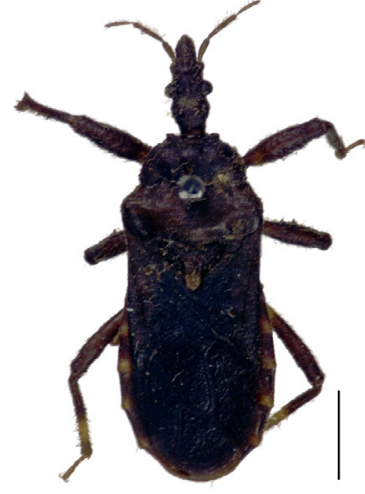

M. monticola comb. nov. Holotype UCR_ENT 00018534

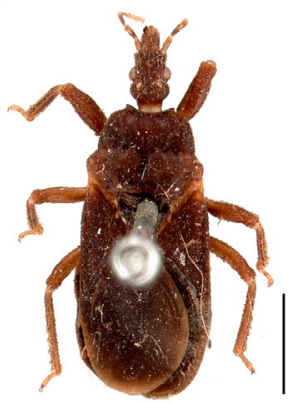

N. dentiscutum comb. nov. Holotype UCR_ENT 00037370

Fig. 10. Dorsal habitus images for species of Macrophysoderes gen. nov. and Nanophysoderes gen. nov. For an explanation of the colored arrows, see key on page 37. Scale bars $=2 \mathrm{~mm}$. 
3. Anterior two-thirds of connexivum dark brown, posterior third straw-colored (Fig. 10, dark blue arrow), anterior margin of male mediosternite 8 without apodeme, apical margin of posterior opening of pygophore smooth, without medial process, cup-like sclerite smooth, apically rounded (Fig. 8, black arrow)

M. monticola (Miller, 1940) comb. nov.

- Connexivum dark brown, posterior margin straw-colored (Fig. 10, light blue arrow), anterior margin of male mediosternite 8 with apodeme, apical margin of posterior opening of pygophore with small medial process, cup-like sclerite apex with a medial process (Fig. 8, grey arrow) ... M. modesta (Miller, 1940) comb. nov.

4. Dorsal surface of pronotum glabrous (Fig. 10, orange arrow)

- Dorsal surface of pronotum, at least along ridges, with dispersed curved setae (Fig. 10, brown arrow)

5. Very large (11.58-12.66 mm), scape surpassing apex of clypeus, head with pair of long, straight setae along posterior margin of postocular lobe, antero-lateral pronotal projections truncate (Fig. 10, orange arrow)

M. grandis gen. et sp. nov.

- Medium (9 mm), scape reaching apex of clypeus, head without pair of long, straight setae along posterior margin of postocular lobe, antero-lateral pronotal projections acute and diverging .......

M. bengalensis (Distant, 1909) comb. nov.

6. Medium to very large $(9.47-11.11 \mathrm{~mm}$ ), scutellar process short and spatulate (Fig. 10, light green arrow), fore femur extremely incrassate, abdomen relatively long ........ elongata gen. et sp. nov.

- Small to very large $(7.16-11.01 \mathrm{~mm})$, scutellar process subacute or rounded, not spatulate (Fig. 10 , green arrow), fore femur not extremely incrassate, abdomen not elongated .7

7. Body brownish-black, scape just surpassing apex of clypeus, scutellar process very short, connexivum narrow, abdominal apical margin straight (Fig. 10, light purple arrow)

M. finisterre gen. et sp. nov.

- Body straw-colored and brown, scape reaching apex of clypeus, scutellar process short, connexivum wide, abdominal apical margin rounded (Fig. 10, purple arrow)

M. cirripilosa gen. et sp. nov.

Macrophysoderes bengalensis (Distant, 1909) comb. nov.

Figs 8-10, 12; Appendix

Epirodera bengalensis Distant, 1909: 364.

Physoderes bengalensis - Maldonado 1990: 379.

\section{Diagnosis}

This species is recognized among species of Macrophysoderes gen. nov. by the dark brown coloration, the scape reaching the apex of the clypeus, the very large eyes relative to the head, the absence of paired long setae at the posterior margin of the postocular lobe, the two rows of small setigerous tubercles on the ventral surface of the postocular lobe, the pronotum with deep paramedian carinae, the triangular pronotal paramedian lobes, the spines on the fore trochanter and the straight margin of the abdominal apex. This species is quite distinct from other members of the genus.

\section{Material examined}

Holotype

INDIA: $\sigma^{\lambda}$, Bengal, Pusa, $22.98666^{\circ} \mathrm{N}, 87.855^{\circ} \mathrm{E}$, exact locality, date and collector unknown (UCR_ ENT 00018528) (BMNH). 


\section{Other material}

INDIA: $1 \partial^{\curvearrowright}$, Meghalaya, Khasi Hills, $25.58333^{\circ} \mathrm{N}, 91.63333^{\circ} \mathrm{E}$, no date provided, collector unknown (UCR_ENT 00069412) (BMNH).

\section{Redescription}

\section{Male}

Body LENGTH. Medium size, total length $9 \mathrm{~mm}$.

Coloration (Fig. 10). Brown. Head brown. Scape of antenna brown, other segments missing. First segment of labium brown, second and third straw brown. Anterior lobe of pronotum dark brown, posterior lobe brown, scutellum dark brown, pleuron brown with light brown margin along acetabulum, sternum brown. Corium of hemelytron brown with straw brown apex, membrane dark brown. Femora straw brown with sub-basal and sub-apical brown annulations, tibiae brown, basally straw brown, tarsi and claws straw brown. Abdomen dorsally straw brown, ventrally straw brown with lateral brown patterns, connexivum yellow brown with anterior indistinct brown spot, exposed part of pygophore straw-colored.

VestituRE. Sparsely setose. Head with some flat, curved setae, ventral surface of postocular lobe with two rows of small, setigerous tubercles. Anterior lobe of thorax with irregular row of tuberculated, short, curved setae on lateral margins and short, setigerous tubercles dispersed on dorsal surface, posterior lobe with only short, sparse setae. Corium of hemelytron glabrous. Fore trochanter of legs with small process on internal surface, fore femur with two rows of spines and setigerous tubercles, fore tibiae with regular rows of tuberculated, stout, sharp setae. Connexival margin of abdomen without setae.

HEAD. Short conical; maxillary plate rounded apically; scape reaching apex of clypeus; eye about 1/5 length of head, not attaining ventral margin of head in lateral view; height of anteocular lobe shorter than postocular lobe.

THORAX. Antero-lateral paired projections acute, diverging; surface of anterior lobe with low ridges; paramedian carina strongly defined; posterior lobe medially weakly rugose; anterior pronotal lobe shorter than posterior lobe, narrower than posterior lobe, anterior lobe lower than posterior lobe in lateral view; parascutellar lobe triangular; scutellar process long, with acute apex.

Hemelytron. Attaining tip of abdomen.

LEGS. Same as genus description.

AвDOMEN. Elongate ovoid, with straight terminal margin; connexival margin smooth.

Genitalia. Anterior margin of mediosternite 8 undulating, without medial apodeme; transverse bridge of pygophore extremely narrow, only consisting of margin of anterior opening of pygophore, margin of anterior opening rounded; cup-like sclerite apically rounded, with sclerotized paired latero-ventral protuberance; arms of basal plate converging; ductifer with sclerotized elongate ring; endosomal struts apically truncate, divided into two arms; shape of dorsal phallothecal sclerite subacute with lateral broad, plate-like prolongations, small acute apex and broad lateral plates with rounded margins extended laterally and curved towards apex.

\section{Female}

Unknown. 


\section{Ecology}

Nothing is known about the biology of this species.

\section{Distribution}

This species is only known from two localities: Pusa, Bengal (type locality) and Khasia Hills, Assam. It appears to be restricted to areas adjoining the Indian subcontinent and Myanmar.

\section{Remarks}

This species is placed in the Macrophysoderes gen. nov. clade based on the phylogenetic analysis above. It is most closely related to $M$. monticola comb. nov., as both possess a scape that reaches the apex of the clypeus and lack the paired, long setae at the posterior margin of the postocular lobe. M. bengalensis comb. nov. possesses several unique characters, especially on the male genitalia.

\section{Macrophysoderes cirripilosa sp. nov. urn:1sid:zoobank.org:act:9B61EDE2-4732-4BCB-92B7-8C200A34A7BE}

Figs 8-12; Appendix

\section{Diagnosis}

This species is recognized among species of Macrophysoderes gen. nov. by the short conical head that is covered with semi-erect, curved setae, with a distinct concentration of setae on the postocular lobe between the ocelli, the length of the scape reaching the apex of the clypeus, the very large eye that attains the ventral margin of the head in lateral view, the median pronotal depression not contiguous with the transverse sulcus and the short scutellar process. It most closely resembles $M$. finisterre gen. et sp. nov. and M. elongata gen. et sp. nov. It is differentiated from the former by the overall coloration, the shape of the antero-lateral pronotal projections, the wider anterior pronotal lobe and the shape of the abdominal apical margin. It is differentiated from $M$. elongata gen. et sp. nov. by the size, the shape of the scutellar process, the relative length of head to body and the less swollen fore femur.

\section{Etymology}

The name combines the Latin noun "cirrus", meaning curl or hair-tuft, with the Latin adjective "pilosus", meaning hairy, to describe the abundant, curved setae on the head, especially between the ocelli.

\section{Material examined}

\section{Holotype}

PAPUA NEW GUINEA: ^̊, Western Province, Fly River, Kiunga, $6.11944^{\circ} \mathrm{S}, 141.29194^{\circ}$ E, 8-10 Aug. 1957, W.W. Brandt leg. (UCR_ENT 00073448) (BPBM).

\section{Paratypes}

PAPUA NEW GUINEA: $4 \hat{\partial} \hat{\partial}$, same collection data as for holotype (UCR_ENT 00073446, UCR_ENT 00073447, UCR_ENT 00073453, UCR_ENT 00073454)(BPBM).

\section{Other material}

INDONESIA: Irian Jaya: 1 q, Cyclops Mts, Ifar, $2.6^{\circ} \mathrm{S}, 140.61^{\circ} \mathrm{E}, 300 \mathrm{~m}, 23-25 \mathrm{Jul} .1962$, J. Sedlacek leg. (UCR_ENT 00073499) (BPBM); 1 o, Cyclops Mts, $2.8775^{\circ} \mathrm{S}, 140.70333^{\circ} \mathrm{E}, 1067 \mathrm{~m}$, Mar. 1936, L.E. Cheesman leg. (UCR_ENT 00069271) (BMNH); 1 đo, Cyclops Mts, Mt Lina, $2.43055^{\circ}$ S, $140.45333^{\circ} \mathrm{E}, 1067 \mathrm{~m}$, Mar. 1936, L.E. Cheesman leg. (UCR_ENT 00069263) (BMNH); 1 §ै, Guega, W of Swart Valley, $3.6^{\circ} \mathrm{S}, 138.41666^{\circ} \mathrm{E}, 1200 \mathrm{~m}, 15$ Nov. 1958, J.L. Gressitt leg. (UCR_ENT 00073468) (BPBM); 1 ㅇ, Ifar, Cyclops Mts, $2.83166^{\circ} \mathrm{S}, 140.60555^{\circ} \mathrm{E}, 450 \mathrm{~m}, 8$ Sep. 1962, J. Sedlacek leg. (UCR ENT 00073500) (BPBM); 1 §ै, Yapen, $1.79472^{\circ} \mathrm{S}, 136.30361^{\circ} \mathrm{E}, 600 \mathrm{~m}, 4$ Jan. 2007, S. Bily leg. 
(UCR_ENT 00073850) (NMPC). - Papua: 1 O̊, Paniai Division Co., Wisselmeren Enarotadi, $4.205^{\circ}$ S, $136.59305^{\circ}$ E, $1900 \mathrm{~m}, 16 \mathrm{Jul} .1962$, J. Sedlacek leg. (UCR_ENT 00073466) (BPBM); 1 + , Araboebivak, $2.61527^{\circ} \mathrm{S}, 140.62805^{\circ} \mathrm{E}, 6$ Oct. 1939, collector unknown (UCR_ENT 00024031) (RMNH); 1 ․ Araucaria Camp, 5.65916 $\mathrm{S}, 139.13583^{\circ} \mathrm{E}, 800 \mathrm{~m}$, Mar. 1939, L.J. Toxopeus leg. (UCR_ENT 00024011) (RMNH); 1 + , Bernhard Camp, $6.21305^{\circ} \mathrm{S}, 141.54805^{\circ} \mathrm{E}, 50 \mathrm{~m}, 5$ Oct. 1938, J. Olthof leg. (UCR_ENT 00014057) $(\mathrm{RMNH}) ; 2$ + $\odot$, same collection data as preceding but Aug. 1938 (UCR_ENT 00024007, UCR_ENT 00024008) (RMNH); 2 우, same collection data as preceding but Jul.--Nov. 1938 (UCR_ENT 00024009, UCR_ENT 00024010) (RMNH); 1 ô., Hollandia (Jayapura), $2.61527^{\circ} \mathrm{S}$, $140.62805^{\circ}$ E, $500 \mathrm{~m}$, Jul. 1938, L.J. Toxopeus leg. (UCR_ENT 00024005) (RMNH); 1 ๙े, Nabire, S Geelwink Bay, $3.36667^{\circ}$ S, $135.48333^{\circ}$ E, 2-9 Jul. 1962, J.L. Gressitt leg. (UCR_ENT 00073469) (BPBM); 1 Oे, Sibil, Star Mountain Range, $5.2375^{\circ} \mathrm{S}, 141.14861^{\circ} \mathrm{E}, 1260 \mathrm{~m}, 18$ Apr. 1959, collector unknown(UCR_ENT 00024028)(RMNH); 1 ô, same collection data as preceding but 21 Apr. 1959(UCR ENT 00024030)(RMNH); 1 §, same collection data as preceding but 25 Apr. 1959 (UCR_ENT 00024029) $(\mathrm{RMNH}) ; 1 \hat{\mathrm{O}}$, same collection data as preceding but 25 May 1959 (UCR_ENT 00024006) (RMNH); 1 ․ Wamena, $4.10055^{\circ} \mathrm{S}, 138.90472^{\circ} \mathrm{E}, 700 \mathrm{~m}, 10-25 \mathrm{Feb} .1960$, T.C. Maa leg. (UCR_ENT 00073485) (BPBM), 3 ठึ, same collection data as preceding (UCR_ENT 00073530-UCR_ENT 00073532) (BPBM).

PAPUA NEW GUINEA: Bougainville Province: $1 \hat{\jmath}$, Mt Nomo, $\mathrm{S}$ of Mt Bougainville, $6.05361^{\circ} \mathrm{S}$, $155.19055^{\circ}$ E, 213 m, Feb. 1936, L.E. Cheesman leg. (UCR_ENT 00069295) (BMNH). - Central

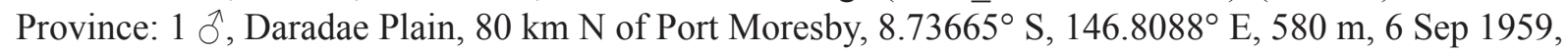
T.C. Maa leg. (UCR_ENT 00073480) (BPBM); 1 Ĵ, Iriri, near Kerema, $8.98416^{\circ} \mathrm{S}, 146.98944^{\circ} \mathrm{E}$, 7 May 1959, C.D. Michener leg. (UCR_ENT 00073484) (BPBM); 1 q, Murua River near Kerema, $8.08361^{\circ} \mathrm{S}, 145.91138^{\circ}$ E, 6 May 1959, C.D. Michener leg. (UCR_ENT 00073492) (BPBM); 1 \%, Otomata Plantation, $1 \mathrm{mi}$. E of Moresby, $9.48166^{\circ} \mathrm{S}, 147.10361^{\circ} \mathrm{E}, 2$ Nov. 1960, J.L. Gressitt leg.

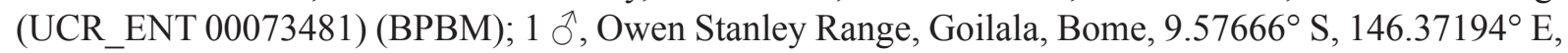
1950 m, 8-15 Mar. 1958, W.W. Brandt leg. (UCR_ENT 00073483) (BPBM); 1 \&, Owen Stanley Range, Goilala, Loloipa, $9.23583^{\circ} \mathrm{S}, 147.98444^{\circ} \mathrm{E}, 1-15 \mathrm{Feb} .1958$, W.W. Brandt leg. (UCR_ENT 00073498)

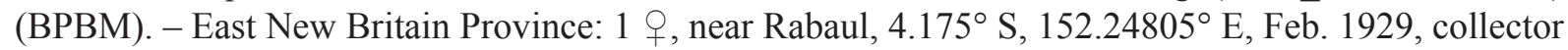
unknown (UCR_ENT 00046667) (CAS). - East Sepik Province: 1 , Amboin Patrol Post, Karawari Lodge, $4.40444^{\circ} \mathrm{S}, 142.98555^{\circ}$ E, Feb. 1983, A.C. Messer leg. (UCR_ENT 00031394) (USNM); 1 q, Mar.-Apr. 1983, A.C. Messer leg. (UCR_ENT 00031395) (USNM); 1 q, May River, 4.40694 S, $141.83944^{\circ}$ E, 6 Jun. 1963, R. Straatman leg. (UCR_ENT 00073503) (BPBM). - Madang Province: 1 ô, Erima, Astrolabe Bay, $5.4225^{\circ} \mathrm{S}, 145.73361^{\circ} \mathrm{E}, 1897$, Biro leg. (UCR_ENT 00069770) (HNHM); 1 q, same collection data as preceding (UCR_ENT 00069777) (HNHM); $\overline{1} \hat{\jmath}$, same collection data as preceding but 1896 (UCR_ENT 00069767) (HNHM); 5 우우, same collection data as preceding (UCR ENT 00069772-UCR_ENT 00069776) (HNHM); 1 o, Mondo, 5.41666 ${ }^{\circ} \mathrm{S}, 144.76138^{\circ} \mathrm{E}, 1524 \mathrm{~m}$, Feb. 1934, L.E. Cheesman leg. (UCR_ENT 00069261) (BMNH); 1 J, Stephansort, Astrolabe Bay, $5.43638^{\circ} \mathrm{S}, 145.74138^{\circ} \mathrm{E}, 1897$, Biro leg. (UCR_ENT 00069771) (HNHM). - Morobe Province: $2 \delta^{\widehat{\partial}} \mathrm{O}^{\top}$, Huon Penninsula Co., Finschhafen, $6.55527^{\circ}$ S, $147.17361^{\circ}$ E, 20 Apr. 1944, E.S. Ross leg. (UCR_ENT 00046650, UCR_ENT 00046651) (CAS); 1 \%, same collection data as preceding (UCR_ENT 00046654) (CAS); 1 ○, same locality as preceding, May 1944, F. Skinner leg. (UCR_ENT 00046655) (CAS); 1 ô, same locality as preceding, 7 May 1944, E.S. Ross leg. (UCR_ENT 00046652) (CAS); 1 ô, same locality as preceding, May 1944, E.S. Ross leg. (UCR_ENT 00046653) (CAS); 1 q, 15 Nov. 1969, J.E. Tobler leg. (UCR_ENT 00046673) (CAS); 1 क , Huon Gulf, Morobe District, $6.55861^{\circ} \mathrm{S}$, $147.50805^{\circ}$ E, 22 May-19 Jun. 1937, J.L. Froggatt leg. (UCR_ENT 00069312) (BMNH); 1 ภे, Sattelberg, Huon-Golf, $6.485^{\circ} \mathrm{S}, 147.75861^{\circ} \mathrm{E}, 1899$, Biro leg. (UCR_ENT 00069788) (HNHM); 1 ô, same collection data as preceding but 1898 (UCR_ENT 00069787) (HNHM); 1 oे, Bulolo, 7.20472 ${ }^{\circ} \mathrm{S}$, $146.63166^{\circ}$ E, 900 m, 27 Mar. 1968, P. Colman leg. (UCR_ENT 00073467) (BPBM); 1 क, same collection data as preceding (UCR_ENT 00073501) (BPBM); 1 क, Bumayong, 6.63444 ${ }^{\circ} \mathrm{S}$, 
HWANG W.S. \& WEIRAUCH C., Phylogeny and revision of Physoderes and allied genera

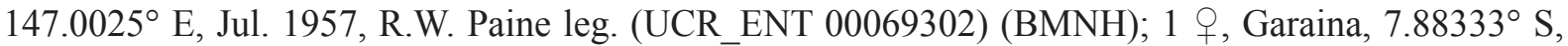
$147.13333^{\circ}$ E, 800 m, 4 Jan. 1968, J. and M. Sedlacek leg. (UCR_ENT 00073496) (BPBM); 3 §ోळ, same collection data as preceding but 15 Jan. 1968 (UCR_ENT 00073474-UCR_ENT 00073476) (BPBM); 1 §ै, same collection data as preceding but 13-15 Jan. 1968 (UCR_ENT 00073477) (BPBM);

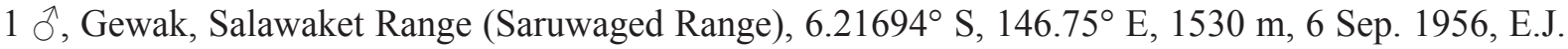

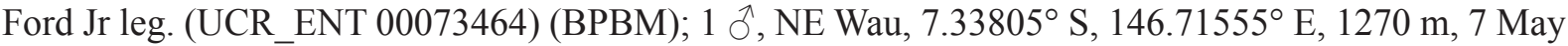
1962, J. Sedlacek leg. (UCR_ENT 00073612) (BPBM); 1 đ, same collection data as preceding but 2-4 Jan. 1963 (UCR_ENT 00073607) (BPBM); 1 क, NE Wau, 7.33166 $\mathrm{S}, 146.71805^{\circ} \mathrm{E}, 1010 \mathrm{~m}, 18$ Dec.

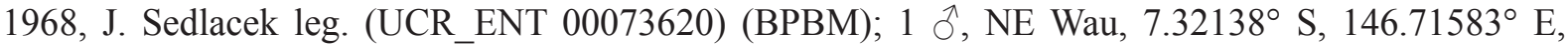
1050 m, 5 Jan. 1963, G. Monteith leg. (UCR_ENT 00073611) (BPBM); 2 đo , same collection data as preceding but 7 Jan. 1963, J. Sedlacek leg. (UCR_ENT 00073609, UCR_ENT 00073610) (BPBM); 1 q, same collection data as preceding (UCR_ENT 00073613) (BPBM); $1 \bar{\delta}$, NE Wau, Hospital Creek, $7.33805^{\circ} \mathrm{S}, 146.71555^{\circ} \mathrm{E}, 1300 \mathrm{~m}, 5$ Dec. 1965, J. Sedlacek leg. (UCR_ENT 00073606) (BPBM); 1 \%, NE Wau, Mt Missim, 7.1167 ${ }^{\circ}$ S, $146.9167^{\circ}$ E, 950-1300 m, Mar. 1965, J. and M. Sedlacek leg. (UCR_ ENT 00073478) (BPBM); 2 $\lesssim$ , Waing, ca 18 mi. (?) of Lae, $6.72444^{\circ} \mathrm{S}, 146.96805^{\circ} \mathrm{E}, 13-14$ Apr. 1965, Balogh and Szent-Ivany leg. (UCR_ENT 00069768, UCR_ENT 00069769); 1 9 , same collection data as preceding (UCR_ENT 00069778) (HNHM); 1 \%, Wau, $7.33333^{\circ} \mathrm{S}, 146.71667^{\circ} \mathrm{E}$, Jan.-Mar. 1982, R.T. Bell leg. (UCR_ENT 00073618) (BPBM); 2 q , same collection data as preceding but FebMay 1982 (UCR_ENT 00073616, UCR_ENT 00073617) (BPBM); 1 o, Wau, 7.32138 S, $146.71555^{\circ}$ E, 1097 m, 11 Sep. 1971, W. Gagne leg. (UCR_ENT 00046657) (CAS); 1 o, Wau, $7.3333^{\circ}$ S, $146.71667^{\circ}$ E, 1200 m, 27 Jul. 1961, J. and J.H. Sedlacek leg. (UCR_ENT 00073614) (BPBM); 1 ${ }^{7}$, same collection data as preceding but 23 Dec. 1961, G. Monteith leg. (UCR_ENT

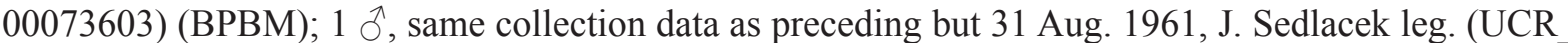
ENT 00073602) (BPBM); 1 \%, same collection data as preceding but 18-25 Jun. 1962 (UCR_ENT 00073599) (BPBM); 1 đै, same collection data as preceding but 14-24 Mar. 1964 (UCR_ENT 00073601) (BPBM); 1 $\hat{\text { }}$, same collection data as preceding but 17-19 Sep. 1964 (UCR_ENT 00073600) (BPBM); 1 § , 8-14 Dec. 1976, G.F. Hevel and R.E. Dietz IV leg. (UCR_ENT 00031396) (USNM); 1 ○, Wau, $7.3333^{\circ} \mathrm{S}, 146.71667^{\circ} \mathrm{E}, 1300 \mathrm{~m}, 24$ Nov. 1963, J.L. Gressitt leg. (UCR ENT 00073605) (BPBM); 1 ô, Wau, $7.3333^{\circ} \mathrm{S}, 146.71667^{\circ} \mathrm{E}, 1100 \mathrm{~m}, 4$ Oct. 1962, J. Sedlacek leg. (UCR ENT 00073604)

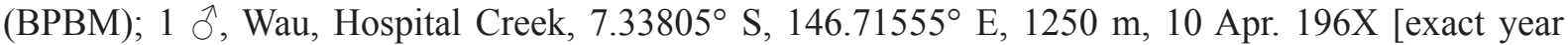
unknown], J. and M. Sedlacek leg. (UCR ENT 00073608) (BPBM); 1 ㅇ, Wau Ecological Institute, $7.33805^{\circ} \mathrm{S}, 146.71555^{\circ}$ E, 4 Dec. 1988, R. Holyuski leg. (UCR ENT 00069789) (HNHM). - Northern Province: 1 ô, SE Popondetta, $8.76666^{\circ} \mathrm{S}, 148.23333^{\circ} \mathrm{E}, 25 \mathrm{~m}$, May 1966, P. Shanahan leg. (UCR ENT 00073465) (BPBM). - Oro Province: 1 ㅇ, Kokoda, $8.86083^{\circ} \mathrm{S}, 147.73722^{\circ} \mathrm{E}, 350 \mathrm{~m}, 21 \mathrm{Mar}$. 1956, J.L. Gressitt leg. (UCR_ENT 00073497) (BPBM); 2 우우, Kokoda, 8.87777 S, $147.7375^{\circ}$ E, 366 m, Apr. 1933, L.E. Cheesman leg. (UCR_ENT 00069264, UCR_ENT 00069265) (BMNH); 2 우, Kokoda, $8.87722^{\circ} \mathrm{S}, 147.7375^{\circ} \mathrm{E}, 366 \mathrm{~m}$, Jun. 1933, L.E. Cheesman leg. (UCR ENT 00069268, UCR ENT 00069269) (BMNH); $3 \hat{\partial} \hat{o}$, same collection data as preceding but Sep. 1933 (UCR ENT 00069258-UCR ENT 00069260) (BMNH); 2 오, same collection data as preceding (UCR ENT

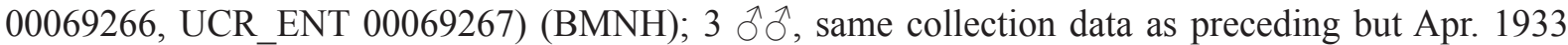
(UCR_ENT 00069255-UCR_ENT 00069257) (BMNH); 1 §, Kokoda-Pitoki, $8.8775^{\circ} \mathrm{S}, 147.73722^{\circ} \mathrm{E}$, 400 m, 24 Mar. 1956, J.L. Gressitt leg. (UCR ENT 00073461) (BPBM); $2 \partial^{\lambda}$, same collection data as preceding but 23 Mar. 1956 (UCR_ENT 00073459, UCR_ENT 00073460) (BPBM); 1 क, same collection data as preceding (UCR ENT 00073491) (BPBM); 1 今, NE Kokoda, 8.86861 ${ }^{\circ} \mathrm{S}$, $147.74777^{\circ}$ E, 400 m, 17-18 Nov. 1965, J. and M. Sedlacek leg. (UCR_ENT 00073462) (BPBM); 1 , same collection data as preceding but 19 Nov. 1965 (UCR_ENT 00073463) (BPBM). - Sandaun (West Sepik) Province: 1 đo, Waris, S of Hollandia, 3.26667 S, $141.05^{\circ}$ E, 450-500 m, 16-23 Aug. 1959, T.C.

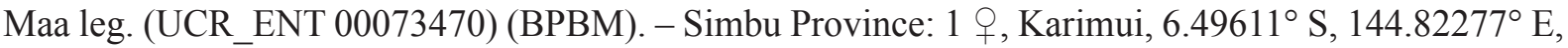
1080 m, 13 Jul. 1963, J. Sedlacek leg. (UCR_ENT 00073504) (BPBM). - West New Britain Province: 1 ㅇ, Silanga, Nakanai Mts, 5.5525 S, $150.87^{\circ}$ E, 150 m, 31 Jul. 1956, E.J. Ford Jr leg. (UCR_ENT 
00073507) (BPBM). - Western Highlands Province: 1 đ̂, Wum, Upper Jimmi Valley, 5.92972 ${ }^{\circ}$ S, $144.26805^{\circ}$ E, $840 \mathrm{~m}, 18$ Jul. 1955, J.L. Gressitt leg. (UCR_ENT 00073482) (BPBM). - Western Province: 1 ô, Eliptamin Valley, 5.17638 S, $141.54361^{\circ}$ E, 1200-1350 m, 16-30 Aug. 1959, W.W. Brandt leg. (UCR_ENT 00073479) (BPBM); 1 q, same collection data as preceding but 1-15 Sep. 1959

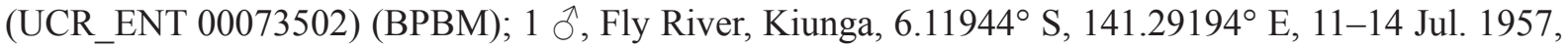
W.W. Brandt leg. (UCR_ENT 00073458) (BPBM); 2 우, same collection data as preceding (UCR ENT 00073493, UCR_ENT 00073494) (BPBM); 1 §, same collection data as preceding but 23-25 Jul. 1957 (UCR_ENT 00073457) (BPBM); 1 ㅇ, same collection data as preceding (UCR_ENT 00073495) (BPBM); 1 , same collection data as preceding but 5-7 Aug. 1957 (UCR_ENT 00073456) (BPBM);

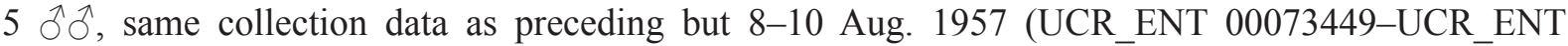
00073452, UCR_ENT 00073455); 5 우, same collection data as preceding (UCR_ENT 00073486-

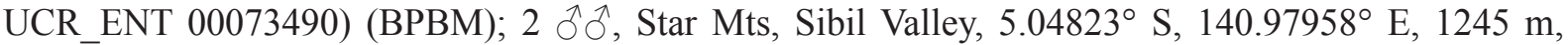
18 Oct.-8 Nov. 1961, S. and L. Quate leg. (UCR_ENT 00073472, UCR_ENT 00073473) (BPBM); 1 q, Koitaki, $8.92527^{\circ} \mathrm{S}, 147.73861^{\circ} \mathrm{E}, 457 \mathrm{~m}$, Nov.-Dec. 1928, collector unknown (UCR_ENT 00046656) (CAS); 1 §ै, Maffin Bay, Dutch New Guinea, $2.09222^{\circ}$ S, $139.01472^{\circ}$ E, Sep. 1944, E.S. Ross leg. (UCR_ENT 00046658) (CAS); $1 \mathrm{O}^{\top}$, Peria Creek, Kwagira River, $9.63111^{\circ} \mathrm{S}, 149.38555^{\circ} \mathrm{E}, 50 \mathrm{~m}$, 14 Aug.-6 Sep. 1953, G.M. Tate leg. (UCR_ENT 00068948) (AMNH); 2 우, Kalalo, 6.76 ${ }^{\circ}$ S, $147.91027^{\circ}$ E, 750 m, 20-30 Aug. 1966, G.A. Samuelson leg. (UCR_ENT 00073508, UCR_ENT

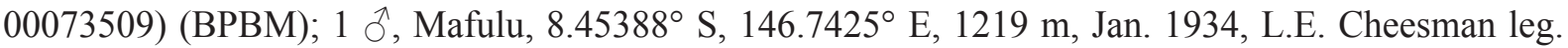
(UCR_ENT 00069262) (BMNH). - $1 \hat{\jmath}$, unknown locality, no date provided, Saunders leg. (UCR_ENT 00069270) (BMNH).

\section{Description}

Male

Body LenGth. Medium size, total length $8.7 \mathrm{~mm}, \mathrm{SD} \pm 0.66$ (Appendix).

Coloration (Figs 10-11). Straw-colored and brown. Head brown. Scape and pedicel of antenna strawcolored, sometimes with brown suffusion, basiflagellomere brown, distiflagellomere straw-colored with brown base. First segment of labium brown with straw-colored apex, second segment basally and apically brown, medially straw-colored, third segment brown. Anterior lobe of pronotum brown with straw-colored markings, posterior lobe straw-colored to light brown, parascutellar lobe with lighter margin, scutellum basally dark brown, apically including process straw-colored, pleuron mixture of straw-color to dark brown, with straw-colored margin of acetabula, sternum dark brown. Corium of hemelytron light brown to brown, membrane brown. Femora straw-colored with basal and apical brown annulations, tibiae straw-colored with basal, medial and apical brown annulations, tarsi and claws strawcolored. Abdomen dorsally dull yellow, ventrally brown medially, straw-colored laterally, with dark brown sub-lateral markings, anterior half of connexivum dark brown, posterior half straw-colored, exposed part of pygophore dark brown.

Vestiture. Densely setose. Head with widespread curved, setigerous tubercles, ventral surface of postocular lobe with two rows of small, setigerous tubercles, with pair of long, straight setae on postocular lobe posterior to ocelli. Anterior lobe of thorax with tuberculated, short, curved setae on lateral margins and along dorsal ridges, posterior lobe with short, curved setae on humeral angle and sparsely distributed along dorsal surface. Corium of hemelytron with short, curved setae. Legs with two rows of spines and setigerous tubercles, tibiae with regular rows of tuberculated, stout, sharp setae. Connexival margin of abdomen with a few clubbed setae on each segment.

HEAD. Short conical; maxillary plate rounded apically; scape reaching apex of clypeus; eye distinctly projecting in dorsal view, about $1 / 5$ length of head, attaining ventral margin of head in lateral view; height of anteocular lobe shorter than postocular lobe. 
THorax. Antero-lateral paired projections acute, diverging; surface of anterior lobe with low ridges; median pronotal depression not contiguous with transverse sulcus; paramedian carina strongly defined; posterior lobe medially weakly rugose; anterior pronotal lobe shorter than posterior lobe, slightly narrower than posterior lobe, anterior lobe lower than posterior lobe in lateral view; parascutellar lobe bell-shaped and skewed towards median; scutellar process short with rounded apex.

Hemelytron. Not attaining tip of abdomen.

LeGs. Same as genus description.

Авдомеn. Elongate ovoid, with rounded terminal margin; connexival margin slightly undulating.

Genitalia. Anterior margin of mediosternite 8 sharply emarginated, with medial apodeme; transverse bridge of pygophore narrow, margin of anterior opening rounded; cup-like sclerite apically rounded and rim ventrally sclerotized; arms of basal plate converging; ductifer with sclerotized rounded ring; endosomal struts conical, with subacute apex, basally divided into two plates; dorsal phallothecal sclerite subacute, with lateral, broad, plate-like prolongations, short triangular.

\section{Female}

Similar in size and shape to males except with rounder or wider abdomen.

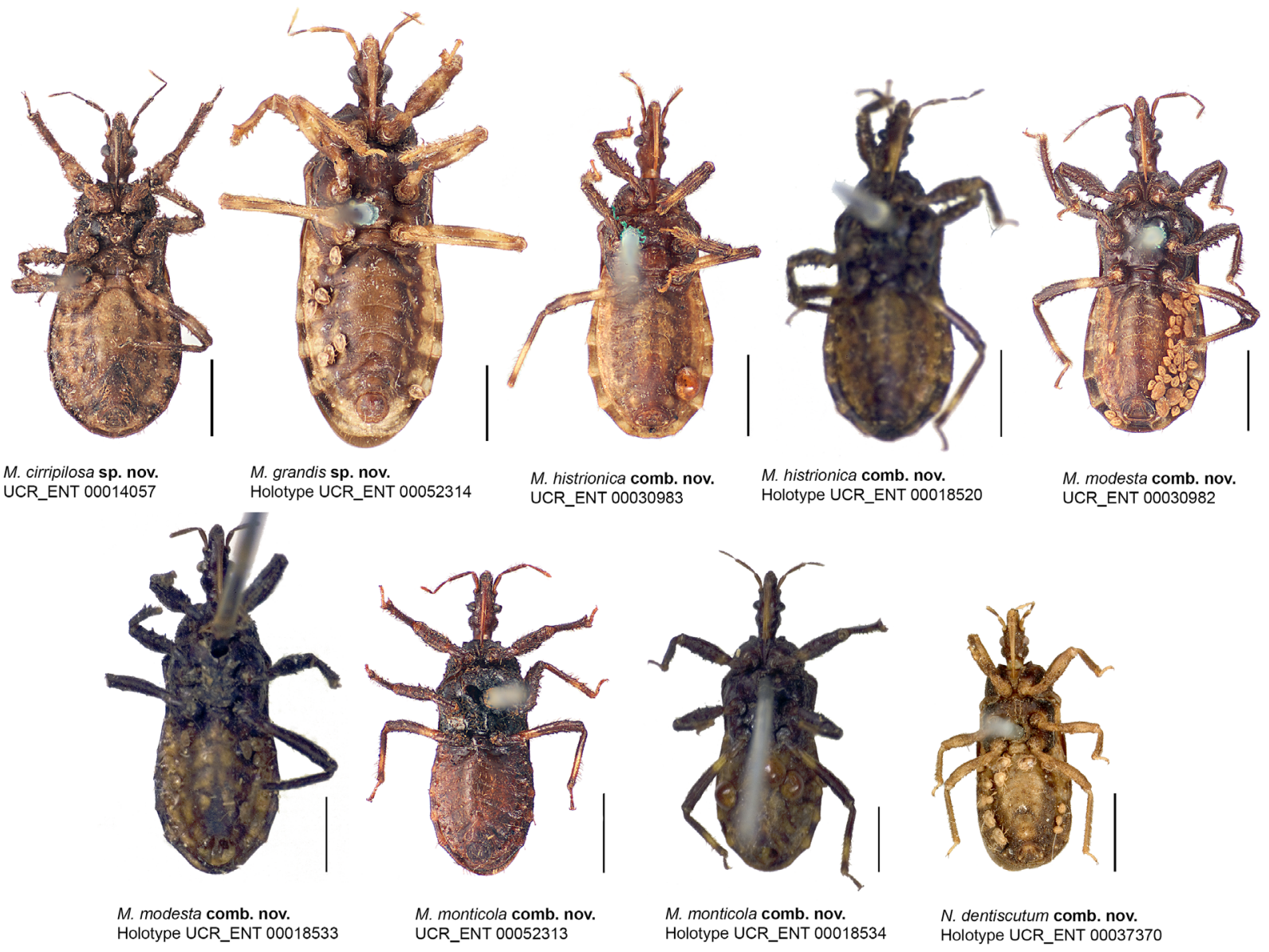

Fig. 11. Ventral habitus images for species of Macrophysoderes gen. nov. and Nanophysoderes gen. nov. Scale bars $=2 \mathrm{~mm}$. 


\section{Ecology}

One specimen was recorded as having been found in logs and another as caught in a light trap.

\section{Distribution}

Found throughout the island of New Guinea, on the nearby island New Britain, and on Bougainville Island (Solomon Archipelago).

\section{Remarks}

This species is described based on the examination of 147 specimens. It is the most commonly collected physoderine from the island of New Guinea. There are slight differences among specimens collected from different regions, most apparently variation of size and color. These differences include overlapping variation and are therefore not indicative of multiple species. Genitalic dissections of specimens from different regions showed no differences. Based on the phylogenetic analysis above, the species is placed in the newly created Macrophysoderes gen. nov. Two other new species, M. grandis gen. et sp. nov. and $M$. elongata gen. et sp. nov., share several characters with $M$. cirripilosa gen. et sp. nov., including the setose head, the very large eyes, the shape of the parascutellar lobe and the anterior pronotal lobe being almost as wide as the posterior lobe.

Macrophysoderes elongata gen. et sp. nov. urn:1sid:zoobank.org:act:B3ACB02E-6EE2-446F-BB49-3B838E3FE625

Figs 8-10, 12; Appendix

\section{Diagnosis}

This species is recognized among species of Macrophysoderes gen. nov. by the large size, the short conical head with semi-erect, curved setae on the postocular lobe between the ocelli, the length of the scape reaching the apex of the clypeus, the very large eye that does not attain the ventral margin of the head in lateral view, the acutely diverging antero-lateral pronotal projections, the wide anterior pronotal lobe that is slightly narrower than the posterior pronotal width, the short and spatulate scutellar process, the extremely incrassate fore femur, the hemelytron surpassing the abdominal tip and the abdominal terminal margin being straight. This species is closest to M. grandis gen. et sp. nov., but is differentiated by the body size, head shape, scape length, eye shape and the shape of the anterior pronotal lobe.

\section{Etymology}

The name elongata is an adjective based on the Latin participle "elongatus" meaning elongate to describe the elongated abdomen unique to this species.

\section{Material examined}

\section{Holotype}

PAPUA NEW GUINEA: ${ }^{\wedge}$, Morobe Province, Mt Missim, $7.1167^{\circ} \mathrm{S}, 146.9167^{\circ} \mathrm{E}, 1600 \mathrm{~m}, 21-24$ Sep. 1964, M. Sedlacek leg. (UCR_ENT 00073634) (BPBM).

\section{Paratypes}

PAPUA NEW GUINEA: Central Province: $1 \partial^{\lambda}$, Owen Stanley Range, Goilala, Bome, $8.45567^{\circ} \mathrm{S}$, $146.7412^{\circ}$ E, $1950 \mathrm{~m}, 24 \mathrm{Feb} .-7$ Mar. 1958, W.W. Brandt leg. (UCR_ENT 00073630) (BPBM). Eastern Highlands Province: 1 J , Goroka-Kabebe, $6.08777^{\circ}$ S, $145.38666^{\circ}$ E, 1800 m, 24 Jun. 1955, J.L. Gressitt leg. (UCR_ENT 00073636) (BPBM). - Morobe Province: $1{ }^{\circ}$, South Garaina, $7.88694^{\circ}$ S, $147.13277^{\circ}$ E, 1800 m, 8-14 Jan. 1968, J. and M. Sedlacek leg. (UCR_ENT 00073633) (BPBM); 1 ○, Wau, Big Wau Creek, 7.33416 ${ }^{\circ}$ S, $146.71833^{\circ}$ E, 1350 m, Sep. 1965, J. and M. Sedlacek leg. (UCR_ ENT 00073583) (BPBM). 


\section{Other material}

PAPUA NEW GUINEA: Eastern Highlands Province: 1 + , Okapa District County, $13 \mathrm{~km}$ SE of Okapa, 6.30388 S, $145.33666^{\circ}$ E, 1650 m, 26 Aug. 1964, J. Sedlacek leg. (UCR_ENT 00073506) (BPBM); 1 ㅇ, Purosa, 20-26 km SE of Okapa, 6.64944 S, 145.56972 ${ }^{\circ}$ E, 2000 m, 28 Aug. 1964, J. Sedlacek leg. (UCR_ENT 00073505) (BPBM); 1 으, Kainantu, 6.28972 ${ }^{\circ} \mathrm{S}, 145.85916^{\circ} \mathrm{E}, 2100 \mathrm{~m}$, 8 Jan. 1965, J. and M. Sedlacek leg. (UCR_ENT 00073637) (BPBM); 2 q $ᄋ$, Moife, $15 \mathrm{~km} \mathrm{NW}$ of Okapa, $6.43206^{\circ} \mathrm{S}, 145.49581^{\circ} \mathrm{E}, 2100 \mathrm{~m}, 11-13$ Oct. 1959, T.C. Maa leg. (UCR_ENT 00073639 , UCR_ENT 00073640)(BPBM). - Gulf Province: 1 đ, NE Wau, Biaru, $8.4875^{\circ} \mathrm{S}, 146.34444^{\circ} \mathrm{E}, 1225 \mathrm{~m}$, 8 Oct. 1978, J.L. Gressitt leg. (UCR_ENT 00073635) (BPBM). - Morobe Province: 1 ઈ, NE Wau, $7.33805^{\circ} \mathrm{S}, 146.71555^{\circ} \mathrm{E}, 1270 \mathrm{~m}, 11$ Sep. 1964, M. Sedlacek leg. (UCR_ENT 00073632) (BPBM); $1 \delta^{\lambda}$, NE Wau, 7.3333 S, $146.71667^{\circ}$ E, 1200 m, 7 Sep. 1961, J. Sedlacek leg. (UCR_ENT 00073631) (BPBM); 1 ㅇ, NE Wau Creek, Wau, 7.33166 S, 146.71805 E, 1500 m, 16-18 Sep. 1964, M. Sedlacek leg. (UCR_ENT 00073619) (BPBM).

\section{Description}

\section{Male}

Body LENGTH. Medium-large size, total length $10.29 \mathrm{~mm}, \mathrm{SD} \pm 0.47$ (Appendix).

Coloration (Fig. 10). Brown. Head brown. Scape of antenna straw-colored to light brown, sometimes with brown apex, pedicel basally brown and apically straw-colored, basiflagellomere brown, distiflagellomere basally brown, apically straw-colored. First segment of labium basally brown, apically light brown, second segment basally and apically brown, medially straw-colored or light brown, third segment brown. Anterior lobe of pronotum dark brown with light brown markings, posterior lobe brown, scutellum basally dark brown, apically including process light brown, pleuron with mixture of strawcolor to dark brown, sternum dark brown. Corium of hemelytron brown to dark brown, membrane dark brown. Femora of legs light-brown with sub-basal and apical dark brown annulations, tibiae light brown with basal, medial and apical dark brown annulations, tarsi and claws brown. Abdomen dorsally yellowish orange, ventrally brown medially with sub-lateral dark and light brown patterns, anterior half of connexivum dark brown, posterior half light brown, exposed part of pygophore brown.

VeStITURE. Sparsely setose. Head with widespread curved setae, ventral surface of postocular lobe with two rows of small, setigerous tubercles, with pair of long, straight setae on postocular lobe, posterior to ocelli. Anterior lobe of thorax with irregular row of tuberculated, short, curved setae on lateral margins and short, setigerous tubercles dispersed on dorsal surface, posterior lobe with short, curved, setigerous tubercles along lateral margins and sparsely distributed on dorsal surface. Corium of hemelytron with short, curved setae. Legs with two rows of spines and setigerous tubercles, tibiae with regular rows of tuberculated, stout, sharp setae. Connexival margin of abdomen with no prominent paired setae, or connexival margin with a few clubbed setae on each segment.

HEAD. Short conical; maxillary plate rounded apically; scape reaching apex of clypeus, or just surpassing apex of clypeus; eye hemispherical in dorsal view, about $1 / 5$ length of head, not attaining ventral margin of head in lateral view; height of anteocular lobe shorter than postocular lobe.

THORAX. Antero-lateral paired projections acute, diverging; surface of anterior lobe smooth, ridges almost obsolete; median pronotal depression not contiguous with transverse sulcus; paramedian carina weakly defined; posterior lobe medially weakly rugose; anterior pronotal lobe of equal length to posterior lobe, slightly narrower than posterior lobe, anterior lobe level with posterior lobe in lateral view; parascutellar lobe bell-shaped and skewed towards median; scutellar process short, apex spatulate; mesosternite with setigerous tubercles, but no protrusion. 
HemelYtron. Surpassing tip of abdomen.

LEGS. Fore femur extremely incrassate.

ABDOMEN. Elongate ovoid, with straight terminal margin; connexival margin smooth.

GeNITALIA. Anterior margin of mediosternite 8 sharply emarginated, with medial apodeme; transverse bridge of pygophore narrow, margin of anterior opening angular; cup-like sclerite apically rounded and rim ventrally sclerotized; arms of basal plate rounded; ductifer membranous; endosomal struts apically spatulate, basally divided into two plates; shape of dorsal phallothecal sclerite subacute with lateral broad, plate-like prolongations, short plates extended diagonally.

\section{Female}

Similar in size and coloration to males, with median depression of anterior pronotal lobe contiguous with transverse sulcus.

\section{Ecology}

This species was collected from high altitudes ranging between 1200 and $2100 \mathrm{~m}$.

\section{Distribution}

This species is known to occur in the highlands of eastern Papua New Guinea.

\section{Remarks}

This species shares characters with M. cirripilosa gen. et sp. nov., including the setose, short, and conical head, the very large eyes, the shape of the parascutellar lobe and the anterior pronotal lobe being almost as wide as the posterior lobe.

Macrophysoderes finisterre gen. et sp. nov. urn:1sid:zoobank.org:act:4956E5F1-A185-4DA2-A4BE-119428AD3D42

Figs 8-10, 12; Appendix

\section{Diagnosis}

This species is recognized among species of Macrophysoderes gen. nov. by the overall brownish-black color, the short conical head with semi-erect, curved setae on the postocular lobe between the ocelli, the length of the scape that just surpasses the apex of the clypeus, the very large eye that attains the ventral margin of the head in lateral view, the very short antero-lateral pronotal projections that are acute and diverging, the narrow anterior pronotal lobe, the very short scutellar process, the narrow connexivum, and the straight abdominal terminal margin. It most closely resembles $M$. cirripilosa gen. et sp. nov. and M. elongata gen. et sp. nov. It is differentiated from the former by the overall coloration, the shape of the antero-lateral pronotal projections, the narrower anterior pronotal lobe and the shape of the abdominal apical margin. It differs from the latter by the size, the shape of the scutellar process, the relative length of the head versus the body and the only slightly swollen fore femur.

\section{Etymology}

The name finisterre is a noun in apposition named after the holotype locality, the Finisterre mountain range in Papua New Guinea.

\section{Material examined}

\section{Holotype}

PAPUA NEW GUINEA: ${ }^{\wedge}$, Madang Province, Finisterre Mts, Damanti, 5.92027 $\mathrm{S}, 146.22555^{\circ} \mathrm{E}$, 1082 m, 2-11 Oct. 1964, collector unknown (UCR_ENT 00069280) (BMNH). 
Paratypes

PAPUA NEW GUINEA: 1 ${ }^{\lambda}$, Madang Province, Finisterre Mts, Damanti, 5.92027 ${ }^{\circ} \mathrm{S}, 146.22555^{\circ} \mathrm{E}$, 1082 m, 2-11 Oct. 1964, collector unknown (UCR_ENT 00069278) (BMNH); 1 §, same collection data as preceding (UCR_ENT 00069276) $(\mathrm{BMNH}) ; 2 \hat{\jmath}$, same collection data as preceding (UCR_ENT 00069274, UCR_ENT 00069275)(BMNH).

\section{Other material}

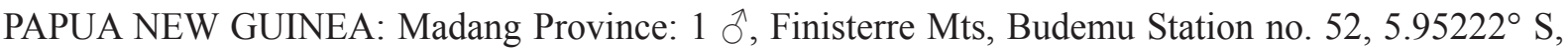
$146.37055^{\circ} \mathrm{E}, 1219 \mathrm{~m}, 15-24$ Oct. 1964, collector unknown (UCR_ENT 00069279) (BMNH); 2 우으, same collection data as preceding (UCR_ENT 00069288,UCR_ENT 00069289)(BMNH); 1 §ै, Finisterre Mts, Damanti Station no. 33, 5.92027 ${ }^{\circ} \mathrm{S}, 146.22555^{\circ} \mathrm{E}, 1082 \mathrm{~m}, 2-11$ Oct. 1964, collector unknown (UCR_ENT 00069277) $(\mathrm{BMNH}) ; 2 \widehat{\partial} \widehat{\partial}$, same collection data as preceding (UCR_ENT 00069272, UCR_ ENT 00069273) (BMNH); 2 우, same collection data as preceding (UCR_ENT 00069285, UCR_ENT 00069286) $(\mathrm{BMNH}) ; 1$ \%, same collection data as preceding but Damanti Station no. 34 (UCR_ENT

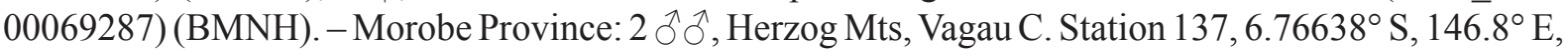
1219 m, 4-17 Jan. 1965, collector unknown (UCR_ENT 00069281, UCR_ENT 00069282) (BMNH); 2 우, same collection data as preceding (UCR_ENT 00069283, UCR_ENT 00069284) (BMNH).

\section{Redescription}

\section{Male}

Body Length. Medium size, total length $8.85 \mathrm{~mm}, \mathrm{SD} \pm 0.38$ (Appendix).

Coloration (Fig. 10). Brownish-black. Head brownish-black. Scape of antenna straw-colored to light brown with brown apex, pedicel light brown suffused with brown, basiflagellomere brown, distiflagellomere basally brown, apically straw-colored. First segment of labium light brown, second segment basally and apically brown, medially straw-colored or light brown, third segment brown. Pronotum brownish-black, with faint brown ridges, scutellum basally brownish-black, apically including process brown, pleuron mixture of straw-color to dark brown, sternum brownish-black. Corium of hemelytron brownish black, membrane brownish black. Femora light-brown with sub-basal and apical dark brown annulations, tibiae light brown with basal, medial and apical dark brown annulations, tarsi and claws brown. Abdomen dorsally dull yellow, ventrally straw-colored or light brown with dark brown suffusion or patterns, anterior half of connexivum dark brown, posterior half light brown, sometimes indistinct, exposed part of pygophore brown.

Vestiture. Densely setose. Head with widespread curved, setigerous tubercles, ventral surface of postocular lobe with two rows of small, setigerous tubercles, with pair of long, straight setae on postocular lobe posterior to ocelli. Anterior lobe of thorax with tuberculated, short, curved setae on lateral margins and along dorsal ridges, posterior lobe with short, curved setae on humeral angle and sparsely distributed along dorsal surface. Corium of hemelytron with short, curved setae. Legs with two rows of spines and setigerous tubercles, tibia with regular rows of tuberculated, stout, sharp setae. Connexival margin of abdomen with a few clubbed setae on each segment.

HEAD. Short conical; maxillary plate rounded apically; scape reaching apex of clypeus or surpassing apex of clypeus; eye distinctly projecting in dorsal view, about $1 / 5$ length of head, attaining ventral margin of head in lateral view; height of anteocular lobe shorter than that of postocular lobe.

Thorax. Antero-lateral paired projections slightly acute, diverging or obsolete; surface of anterior lobe with low ridges; median pronotal depression contiguous with transverse sulcus; paramedian carina strongly defined; posterior lobe medially rugose; anterior pronotal lobe of equal length to posterior lobe, 
narrower than posterior lobe, anterior lobe level with posterior lobe in lateral view; parascutellar lobe bell-shaped and skewed towards median; scutellar process very short, with subacute apex.

Hemelytron. Attaining tip of abdomen.

Legs. Same as genus description.

AвDOMEN. Elongate ovoid, with straight terminal margin; connexival margin slightly undulating.

GeNITALIA. Anterior margin of mediosternite 8 sharply emarginated, without medial apodeme; transverse bridge of pygophore broad, margin of anterior opening angular, apodeme present, apical margin of posterior opening smooth; cup-like sclerite apically rounded and rim ventrally sclerotized; arms of basal plate converging; ductifer with sclerotized rounded ring; endosomal struts conical, with subacute apex, basally divided into two plates; dorsal phallothecal sclerite subacute, with lateral broad, plate-like prolongations, elongated longitudinal plates close to dorsal surface.

\section{Female}

Similar in size and shape to males except having a wider abdomen and connexivum.

\section{Ecology}

This species was collected from an altitude between 1000 and $1200 \mathrm{~m}$.

\section{Distribution}

This species is known only from the Finisterre and Herzog mountain ranges in eastern Papua New Guinea.

\section{Remarks}

Based on the phylogenetic analysis above, this species forms a monophyletic clade together with two other species from Papua New Guinea within Macrophysoderes gen. nov.

Macrophysoderes grandis gen. et sp. nov. urn:1sid:zoobank.org:act:496917F0-28BC-4B33-B2D6-BBAB58A084C8

Figs 8-12; Appendix

\section{Diagnosis}

This species is recognized among other species of Macrophysoderes gen. nov. by its very large size, the elongate conical head, the scape surpassing the apex of the clypeus, the bulbous eye that reaches the ventral margin of the head in lateral view, the truncate antero-lateral pronotal projection, the anterior pronotal lobe being distinctly narrower than the posterior lobe, and the short and spatulate scutellar process. This species is distinctive based on these characters, especially its large size.

\section{Etymology}

The name grandis is an adjective after the Latin "grandis", meaning large, to describe the exceptionally large size of this species.

\section{Material examined}

\section{Holotype}

PAPUA NEW GUINEA: ${ }^{\wedge}$, Morobe Province, Bulolo, $7.20472^{\circ} \mathrm{S}, 146.63166^{\circ} \mathrm{E}, 1010 \mathrm{~m}$, light trap, 23 Aug. 1956, E.J. Ford Jr. leg. (UCR_ENT 00052314) (BPBM). 
HWANG W.S. \& WEIRAUCH C., Phylogeny and revision of Physoderes and allied genera

Paratype

PAPUA NEW GUINEA: 1 \%, same collection data as holotype but 28 Aug. 1956 (UCR_ENT 00073625) (BPBM).

\section{Description}

Male

BODY LENGTH. Very large size, total length $11.58 \mathrm{~mm}$.

Coloration (Figs 10-11). Brown with straw-colored markings. Head brown. Scape and pedicel of antenna straw-colored with brown suffusion, basiflagellomere brown, distiflagellomere straw-colored with brown base. First segment of labium light brown, second segment basally and apically brown, medially straw-colored, third segment brown. Pronotum brown, scutellum basally brown to dark brown, apically straw-colored or light brown, pleuron brown, sternum brown and straw-colored. Corium and membrane of hemelytron brown. Femora of legs straw-colored with sub-basal and apical brown annulations, tibiae straw-colored with basal, medial and apical brown annulations, tarsi and claws strawcolored. Abdomen dorsally dull yellow, ventrally light brown medially with brown and straw-colored sub-lateral patterns, anterior half of connexivum dark brown, posterior half straw-colored.

Vestiture. Glabrous. Head with some flat, curved setae, ventral surface of postocular lobe with a few curved setae, with pair of long, straight setae on postocular lobe posterior to ocelli. Anterior lobe of thorax with irregular row of tuberculated, short, curved setae on lateral margins and glabrous dorsal surface, posterior lobe glabrous. Corium of hemelytron glabrous. Legs with two rows of spines and setigerous tubercles, tibiae with a few prominent tuberculated, stout, sharp setae. Connexival margin of abdomen glabrous.

HEAD. Elongate conical; maxillary plate rounded apically; scape surpassing apex of clypeus; eye distinctly projecting in dorsal view, about $1 / 5$ length of head, reaching ventral margin of head in lateral view; height of anteocular lobe shorter than postocular lobe.

Thorax. Antero-lateral paired projections truncate; surface of anterior lobe smooth, ridges almost obsolete; paramedian carina strongly defined; posterior lobe medially weakly rugose; anterior pronotal lobe shorter than posterior lobe, narrower than posterior lobe, anterior lobe level with posterior lobe in lateral view; parascutellar lobe bell-shaped, skewed towards median; scutellar process short, apex spatulate; mesosternite with median, irregular, tuberculated protrusion between fore and mid coxae.

Hemelytron. Surpassing tip of abdomen.

LEGS. Fore femur distinctly incrassate.

AвDOMEN. Elongate ovoid, with straight terminal margin; connexival margin slightly undulating.

GENITALIA. Anterior margin of mediosternite 8 sharply emarginated, without medial apodeme; transverse bridge of pygophore narrow, margin of anterior opening rounded, apodeme present, apical margin of posterior opening smooth; cup-like sclerite apically rounded and rim ventrally sclerotized; arms of basal plate rounded; ductifer with sclerotized rounded ring; endosomal struts conical, with subacute apex, basally divided into two plates; dorsal phallothecal sclerite subacute, with lateral, broad, plate-like prolongations and short plates extended diagonally.

\section{Female}

Similar in size, shape and color to male, except with lighter colored scutellum. 


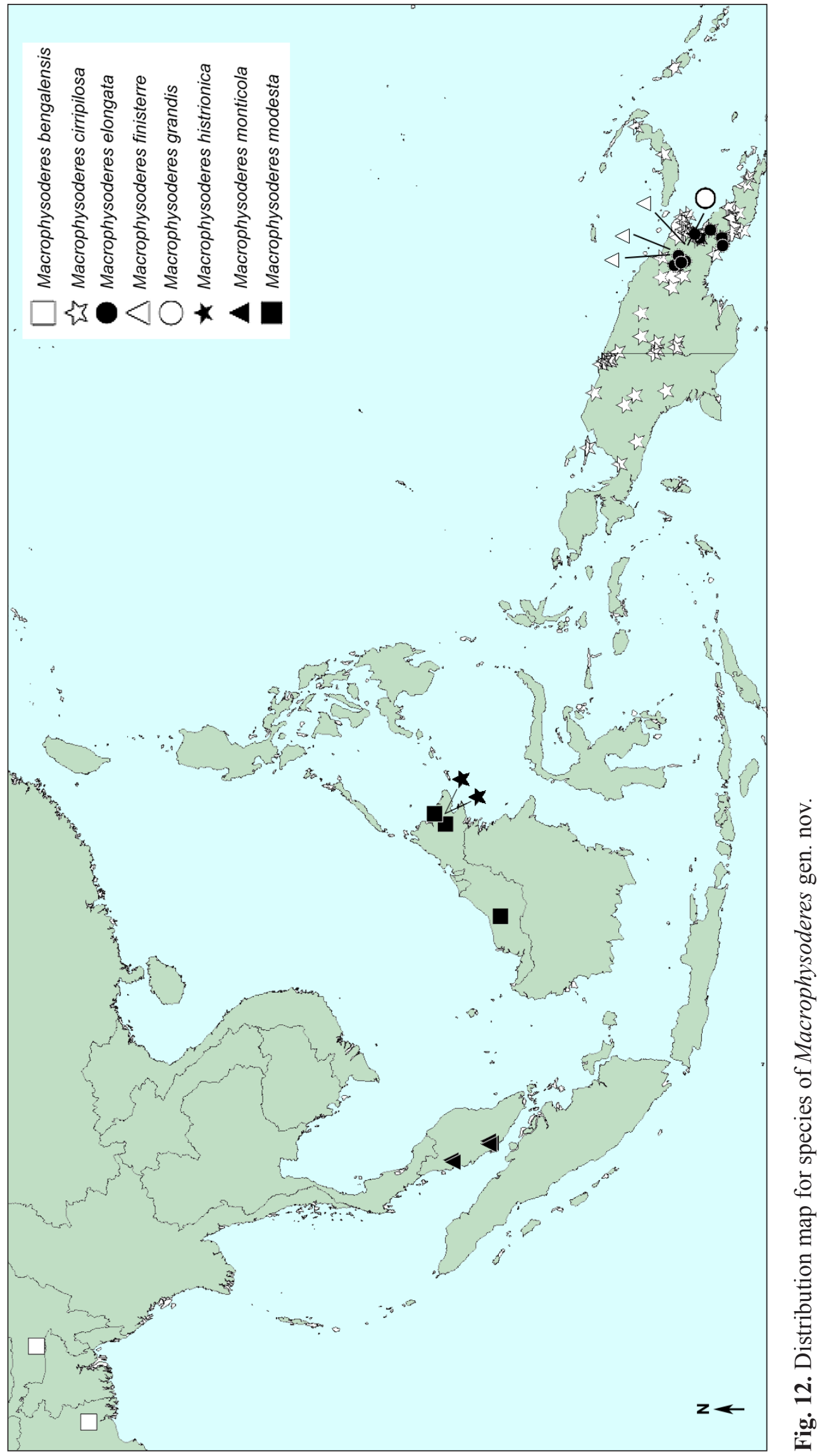




\section{Ecology}

This species is only known from two specimens caught in a light trap set at an altitude of $1010 \mathrm{~m}$.

\section{Distribution}

This species is known only from the type locality of Bulolo, northeast Papua New Guinea.

\section{Remarks}

This species shares characters with M. cirripilosa gen. et sp. nov., including the setose conical head, the very large eyes and the shape of the parascutellar lobe.

Macrophysoderes histrionica (Miller, 1940) comb. nov.

Figs 10-12; Appendix

Physoderes histrionica Miller, 1940: 554, fig. 89.

\section{Diagnosis}

This species is recognized among species of Macrophysoderes gen. nov. by the very large eye, the scape almost reaching the apex of the clypeus, the truncate antero-lateral pronotal projection, the glabrous pronotum, the long, subacute, brownish-black scutellar process and the hind femur being brown with two straw-colored annulations at the base and sub-apex. It most closely resembles M. modesta comb. nov., but is differentiated by the color pattern on the hind femur and the shape of the scutellar spine.

\section{Material examined}

\section{Holotype}

MALAYSIA: ${ }^{\Uparrow}$, Sabah, N Borneo, Bettotan, nr. Sandakan, 5.28222 ${ }^{\circ}$ N, $117.59305^{\circ}$ E, 19 Aug. 1927, C. Boden Kloss and H.M. Pendlebury leg. (UCR_ENT 00018520) (BMNH).

\section{Paratypes}

MALAYSIA: 1 , same collection data as for holotype but 17 Aug. 1927 (UCR_ENT 00018506) (BMNH); 1 , same collection data as for holotype but 2 Aug. 1927 (UCR_ENT 00018502) (BMNH); 1 , same collection data as for holotype but 18 Aug. 1927 (UCR_ENT 00018505) (BMNH).

\section{Other material}

MALAYSIA: 1 , Sabah, Sandakan, $5.8333^{\circ} \mathrm{N}, 118.1167^{\circ} \mathrm{E}, 4 \mathrm{~m}$, no date provided, Baker leg. (UCR_

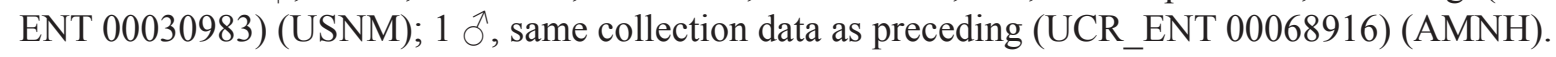

\section{Redescription}

\section{Male}

Body Length. Medium size, total length $8.5 \mathrm{~mm}$.

Coloration (Figs 10-11). Brown. Head brown. Scape of antenna straw-colored with brown apex, pedicel brown with straw-colored apex, basiflagellomere brown, distiflagellomere basally brown, apically straw-colored. First segment of labium brown, second segment straw-colored with brown base, third segment brown. Pronotum brown or dark brown, scutellum dark brown, pleuron brown or dark brown, sternum brown or dark brown. Corium of hemelytron brown or dark brown, membrane brownish-black. Fore and mid femora of legs brown, fore and mid tibiae brown with sub-basal straw-colored annulation, tarsi and claws light brown, hind femur brown with basal and sub-apical straw-colored annulations, hind 
tibia brown with sub-basal straw-colored annulation, tarsus and claw light brown. Abdomen dorsally yellowish-orange, ventrally straw-colored with sub-lateral dark brown suffusion, anterior two-thirds of connexivum dark brown, posterior third straw-colored.

Vestiture. Glabrous. Head with some flat, curved setae, ventral surface of postocular lobe with sparse, setigerous tubercles, with pair of long, straight setae on postocular lobe posterior to ocelli. Anterior lobe of thorax with irregular row of tuberculated, short, curved setae on lateral margins and fine, adpressed setae on dorsal surface, posterior lobe with short, curved setae on humeral angle and sparsely distributed along dorsal surface. Corium of hemelytron glabrous. Legs with two rows of spines and setigerous tubercles, tibiae with regular rows of tuberculated, stout, sharp setae. Connexival margin of abdomen with a few clubbed setae on each segment.

HEAD. Elongate conical; maxillary plate rounded apically; scape not reaching apex of clypeus; eye distinctly projecting in dorsal view, less than $1 / 5$ length of head, not attaining ventral margin of head in lateral view; height of anteocular lobe level with postocular lobe.

Thorax. Antero-lateral paired projections truncate; surface of anterior lobe smooth, ridges almost obsolete; median pronotal depression contiguous with transverse sulcus; paramedian carina weakly defined; posterior lobe medially rugose; anterior pronotal lobe shorter than posterior lobe, narrower than posterior lobe, anterior lobe lower than posterior lobe in lateral view; parascutellar lobe rounded, skewed towards median; scutellar process long, with subacute apex; mesosternite with median, irregular, tuberculated protrusion between fore and mid coxae.

Hemelytron. Surpassing tip of abdomen.

Legs. Same as genus description.

AвDOMEn. Elongate ovoid, with rounded terminal margin; connexival margin undulating.

Genitalia. Not examined.

\section{Female}

Similar in size, shape and color to male except with wider abdomen.

\section{Ecology}

Unknown.

\section{Distribution}

This species is only known from two localities in north Borneo, Sabah.

\section{Remarks}

Macrophysoderes histrionica comb. nov. shares the dark body color, head shape, general vestiture, and the shape of the parascutellar lobe with M. monticola comb. nov. and is thus transferred to the new genus to reflect the hypothesized close relationship. Examination of the type series of $M$. histrionica comb. nov. showed that 3 of the paratypes match the holotype of M. modesta comb. nov. more closely than M. histrionica comb. nov. and these specimens are here treated under M. modesta comb. nov.

Macrophysoderes modesta (Miller, 1940) comb. nov. Figs 7-12; Appendix

Physoderes modesta Miller, 1940: 543, fig. 88.

Physoderes sibauana Miller, 1940: 553, fig. 88. New synonymy.

Physoderes trusana Miller, 1940: 553, fig. 89. New synonymy. 


\section{Diagnosis}

This species is recognized among species of Macrophysoderes gen. nov. by the elongate, conical head, the rounded maxillary plate, the anteocular lobe being almost level with the postocular lobe, the truncate antero-lateral rounded pronotal projections, the rounded parascutellar lobes that are skewed towards the median, the dark brown hind femur with a single basal straw-colored annulation, the apex of the scutellar process being straw-colored, the undulating connexivum, the cup-like sclerite with distinct medial process, and the flap-like prolongations of the phallosoma being plate-like and with a uniform basal margin. It is similar to M. monticola comb. nov. and M. histrionica comb. nov., but can be differentiated by the uniform color of the legs and connexiva, the margin of the pygophore posterior opening having a medial process and cup-like sclerite, and the shape of the plate-like prolongations of the phallosoma.

\section{Material examined}

\section{Holotype}

MALAYSIA: đ̊, Sarawak, N Borneo, $2.56055^{\circ} \mathrm{N}, 113.00555^{\circ} \mathrm{E}, 112 \mathrm{~m}, 1909$, C.J. Brooks leg. (UCR ENT 00018533) (BMNH).

\section{Other material}

MALAYSIA: Sabah: 1 q, N Borneo, Bettotan, nr. Sandakan, 5.28222 ${ }^{\circ}$ N, 117.59305 E, 25 Jul. 1927, C. Boden Kloss and H.M. Pendlebury leg. (UCR_ENT 00018507) (BMNH); 1 \%, same collection data as preceding but 26 Jul. 1927 (UCR_ENT 00018503) (BMNH); 1 \% , same collection data as preceding but 19 Aug. 1927 (UCR_ENT 00018504) (BMNH); 1 q, N Borneo, Sandakan, 5.8333 N, $118.1167^{\circ}$ E, $4 \mathrm{~m}$, no date provided, Baker leg. (UCR_ENT 00030982) (USNM). - Sarawak: 1 , , N Borneo, SAR, $2.55722^{\circ} \mathrm{N}, 113.00111^{\circ} \mathrm{E}, 113 \mathrm{~m}$, no date provided, Saunders leg. (UCR_ENT 00069384) (BMNH); $1 \delta$, same collection data as holotype (UCR_ENT 00069386) (BMNH).

\section{Redescription}

\section{Male}

Body Length. Medium, total length $9.45 \mathrm{~mm}, \mathrm{SD} \pm 0.05$ (Appendix).

Coloration (Figs 7, 10-11). Dark brown. Head dark brown. Scape of antenna brown, straw brown basally, pedicel brown, basi- and distiflagellomere brown. Labium brown. Pronotum dark brown, scutellum dark brown, pleuron dark brown, sternum dark brown. Corium of hemelytron dark brown, membrane black to dark brown. Fore and mid legs dark brown, hind femur dark brown, hind tibia dark brown with straw-colored apex, hind tarsus and claw straw-colored. Abdomen dorsally orange-brown, ventrally light brown to brown with reddish-brown or dark brown lateral suffusion, connexivum dark brown with straw-colored posterior margin.

Vestiture. Glabrous. Head with some flat, curved setae, ventral surface of postocular lobe with sparse, setigerous tubercles, without pair of long, straight setae on postocular lobe posterior to ocelli. Anterior lobe of thorax with irregular row of tuberculated, short, curved setae on lateral margins and fine, adpressed setae on dorsal surface, posterior lobe with only short, sparse setae. Corium of hemelytron with short, sparse, adpressed setae. Legs with two rows of spines and setigerous tubercles, tibiae with regular rows of tuberculated, stout, sharp setae. Posterior margin of connexivum on abdomen with short, fine setae.

HEAD. Elongate conical; maxillary plate rounded apically; scape not reaching apex of clypeus; eye distinctly projecting in dorsal view, less than $1 / 5$ length of head, not attaining ventral margin of head in lateral view; height of anteocular lobe level with postocular lobe. 
Thorax. Antero-lateral paired projections truncate; surface of anterior lobe smooth, ridges almost obsolete; median pronotal depression contiguous with transverse sulcus; paramedian carina weakly defined; posterior lobe medially rugose; anterior pronotal lobe shorter than posterior lobe, narrower than posterior lobe, anterior lobe lower than posterior lobe in lateral view; parascutellar lobe rounded, skewed towards median; scutellar process long, with subacute apex; mesosternite with median irregular tuberculated protrusion between fore and mid coxae.

HemelYtron. Attaining tip of abdomen.

LeGs. Same as genus description.

ABdomen. Elongate ovoid, with rounded terminal margin; connexival margin undulating.

Genitalia. Anterior margin of mediosternite 8 undulating, with medial apodeme; transverse bridge of pygophore broad, margin of anterior opening angular, apodeme present, apical margin of posterior opening with small medial process; cup-like sclerite with medial process; arms of basal plate rounded; ductifer membranous; endosomal struts conical, with subacute apex, basally divided into two arms; shape of dorsal phallothecal sclerite subacute, with lateral broad, plate-like prolongations.

\section{Female}

Similar to male.

\section{Ecology}

Nothing is known about the biology of this species.

\section{Distribution}

This species is collected from both Sabah and Sarawak, Malaysia.

\section{Remarks}

This species is transferred to Macrophysoderes gen. nov. because of the similarities it shares with M. monticola comb. nov. and M. histrionica comb. nov. Examination of the type specimens of P. sibauana and $P$. trusana shows no morphological differences between them and they are hereby synonymized under M. modesta comb. nov.

Macrophysoderes monticola (Miller, 1940) comb. nov.

Figs 7-12; Appendix

Physoderes monticola Miller, 1940: 545, fig. 89.

Physoderes dimidiata Miller, 1940: 556, fig. 92. New synonymy.

Physoderes luiana Miller, 1940: 552, fig. 90. New synonymy.

\section{Diagnosis}

This species is recognized among species of Macrophysoderes gen. nov. by the elongate conical head, the rounded maxillary plate, the anteocular lobe being almost level with the postocular lobe, the truncate antero-lateral pronotal projections, the rounded parascutellar lobes being skewed towards the median, the dark brown hind femur with a single basal straw-colored annulation, the apex of the scutellar process being straw-colored, the connexivum undulating, and the plate-like and angular flap-like prolongations of the phallosoma. It is similar to M. modesta comb. nov. and M. histrionica comb. nov., but can be differentiated by the color of the legs, scutellar spine and connexiva, the shape of the margin of the 
posterior opening of the pygophore and cup-like sclerite, and the shape of the plate-like prolongations of the phallosoma.

\section{Material examined}

\section{Holotype}

MALAYSIA: ${ }^{\top}$, Perak, Taiping Co., Larut Hills, $5.00^{\circ}$ N, $100.88333^{\circ}$ E, 1372 m, 21 Feb. 1932, H.M. Pendlebury leg. (UCR_ENT 00018534)(BMNH).

\section{Paratypes}

MALAYSIA: 1 ㅇ, Perak, Batang Padang Co., Jor Camp, $4.89972^{\circ} \mathrm{N}, 100.79055^{\circ}$ E, $549 \mathrm{~m}, 31$ May 1923, H.M. Pendlebury leg. (UCR_ENT 00069389) (BMNH); 1 + , Perak, Batang Padang Co., Jor Camp, $4.89972^{\circ} \mathrm{N}, 100.79055^{\circ}$ E, $610 \mathrm{~m}, 25$ Aug. 1922, E. Seimund leg. (UCR ENT 00069387) (BMNH).

\section{Other material}

MALAYSIA: 1 क , Perak, Batang Padang Co., Jor Camp, $4.89972^{\circ} \mathrm{N}, 100.79055^{\circ} \mathrm{E}, 610 \mathrm{~m}, 30 \mathrm{Aug}$. 1922, E. Seimund leg. (UCR_ENT 00069388) (BMNH); 1 on, Selangor, Kuala Lumpur, $17^{\text {th }}$ mile Kanching, $3.13888^{\circ}$ N, $101.68666^{\circ}$ E, 22 Oct. 1922, H.M. Pendlebury leg., holotype of $P$. dimidiata (junior synonym) (UCR_ENT 00018521) (BMNH); 1 , same collection data as preceding, paratype of P. dimidiata (junior synonym)(UCR_ENT 00018509)(BMNH); 1 \&, Sungei Lui, Ulu Langat, $3.03805^{\circ} \mathrm{N}$, $101.70583^{\circ}$ E, 86 m, 13 Aug. 1933, N.C.E. Miller leg., holotype of P. luiana (junior synonym) (UCR ENT 00018514) (BMNH); 1 \&, Kuala Sleh, 3.02472 ${ }^{\circ}$ N, 101.71638 ${ }^{\circ}$ E, 17 May 1936, H.M. Pendlebury leg., paratype of $P$. dimidiata (junior synonym) (UCR_ENT 00018508) (BMNH); 1 , Dusun Tua, $3.14555^{\circ} \mathrm{N}, 101.83888^{\circ}$ E, 12 Jan. 1930, H.M. Pendlebury leg. (UCR_ENT 00069390) (BMNH); 1 ô, Gombak Valley, $3.13027^{\circ}$ N, $101.65777^{\circ}$ E, 12 Oct. 1921, H.M. Pendlebury leg. (UCR_ENT 00069391) (BMNH); 1 , Kepong, in forest, $3.2325^{\circ}$ N, $101.6275^{\circ}$ E, Aug. 1949, Army Scrub Typhus Unit leg. (UCR_ENT 00025941) (USNM).

\section{Redescription}

\section{Male}

Body LENGTH. Large, total length $10.34 \mathrm{~mm}$.

Coloration (Figs 7, 10-11). Dark brown. Head dark brown. Scape of antenna brown, straw brown basally, pedicel brown, basi- and distiflagellomere brown. Labium brown. Pronotum dark brown, scutellum dark brown, pleuron dark brown, sternum dark brown. Corium of hemelytron dark brown, membrane black to dark brown. Fore and mid legs dark brown, hind femur dark brown, hind tibia dark brown with straw-colored apex, hind tarsus and claw straw-colored. Abdomen dorsally orange-brown, ventrally light brown with reddish-brown or dark brown suffusion, anterior two-thirds of connexivum dark brown, posterior third straw-colored.

Vestiture. Glabrous. Head with some flat, curved setae, ventral surface of postocular lobe with sparse, setigerous tubercles, without pair of long, straight setae on postocular lobe posterior to ocelli. Anterior lobe of thorax with irregular row of tuberculated, short, curved setae on lateral margins and fine, adpressed setae on dorsal surface, posterior lobe with short, curved setae on humeral angle and sparsely distributed along dorsal surface. Corium of hemelytron with short, sparse, adpressed setae. Legs with two rows of spines and setigerous tubercles, tibia with regular rows of tuberculated, stout, sharp setae. Connexival margin of abdomen with a few clubbed setae on each segment.

HEAD. Elongate conical; maxillary plate rounded apically; scape not reaching apex of clypeus; eye distinctly projecting in dorsal view, less than $1 / 5$ length of head, not reaching ventral margin of head in lateral view; height of anteocular lobe level with postocular lobe. 
Thorax. Antero-lateral paired projections truncate; surface of anterior lobe smooth, ridges almost obsolete; median pronotal depression contiguous with transverse sulcus; paramedian carina weakly defined; posterior lobe medially rugose; anterior pronotal lobe shorter than posterior lobe, narrower than posterior lobe, anterior lobe lower than posterior lobe in lateral view; parascutellar lobe rounded, skewed towards median; scutellar process long, with subacute apex; mesosternite with median irregular tuberculated protrusion between fore and mid coxae.

HemelYtron. Attaining tip of abdomen.

LeGs. Same as genus description.

AвDOMEN. Elongate ovoid, with rounded terminal margin; connexival margin undulating.

GENITALIA. Anterior margin of mediosternite 8 undulating, without medial apodeme; transverse bridge of pygophore broad, margin of anterior opening angular, apodeme present, apical margin of posterior opening smooth; cup-like sclerite apically rounded and rim ventrally sclerotized; arms of basal plate parallel to each other; ductifer membranous; endosomal struts conical, with subacute apex, basally divided into two arms; dorsal phallothecal sclerite subacute, with lateral broad, plate-like prolongations, broad plates angularly oriented towards basal plate.

\section{Female}

Similar to male in size, shape and color.

\section{Ecology}

Nothing is known about the biology of this species.

\section{Distribution}

This species is distributed along the western area of peninsular Malaysia. Specimens from the state of Perak are larger than those from Selangor.

\section{Remarks}

Based on the phylogenetic analysis, this species forms a monophyletic clade with $M$. bengalensis comb. nov. as part of the Macrophysoderes gen. nov. clade. Other species closely resembling M. monticola comb. nov. are also transferred to Macrophysoderes gen. nov. based on the hypothesis that they are most closely related, namely M. modesta comb. nov. and M. histrionica comb. nov. Common characteristics shared among these three species include having an elongate conical head, truncate antero-lateral pronotal projections and a hemelytron with a dark brown membrane. Examination of the type specimens of $P$. dimidiata and $P$. luiana show no morphological differences except for size and are hereby synonymized with $M$. monticola comb. nov. This species and M. modesta comb. nov. are highly similar and difficult to distinguish other than based on the morphology of the male genitalia and on distribution.

\section{Nanophysoderes gen. nov. urn:1sid:zoobank.org:act:B90EE5D9-EDDB-419D-BFC1-141C9E42D4B4}

Figs 10-11, 13; Appendix

\section{Diagnosis}

This genus is recognized among other genera of Physoderinae by the small size, the pair of prominent setigerous tubercles on the ventral surface of the postocular lobe, the lateral margins of the anterior pronotal lobe being almost straight and not curved, the semicircular shape of the scutellum, the scutellum having distinct paired lateral tubercles, the mesosternum having three longitudinal rows of setae and the 
armature of the fore femur consisting of two dense rows of setigerous tubercles. The genus is distinct from any other physoderine genus by the straight lateral margins of the anterior pronotal lobe, small size, uniform coloration, sparse setation over the entire body, paired projections on the scutellum, and the three longitudinal rows of setae on the mesosternum.

\section{Etymology}

The name combines Physoderes after the type genus of Physoderinae and the Latin noun "nanus", meaning dwarf, to indicate small body size. The gender is feminine.

\section{Type species}

Physoderes dentiscutum Bergroth, 1906.

\section{Description}

\section{Female}

Body Length. Small, total length $7.66 \mathrm{~mm}$.

Coloration (Figs 10-11; Nanophysoderes dentiscutum comb. nov.). Brown to straw brown. Head brown, neck straw brown. Antenna straw brown with brown suffusion. Labium straw brown. Pronotum brown, scutellum brown, pleuron brown, sternum brown. Corium of hemelytron brown, membrane brown. Legs straw brown. Abdomen yellow dorsally, straw brown ventrally with lateral brown suffusion, anterior half of connexivum brown, posterior half straw-colored, margin indistinct.

Vestiture. Sparsely setose. Head with some flat, curved setae or with widespread short, fine, adpressed setae, ventral surface of postocular lobe with only a pair of prominent setigerous tubercles, with pair of long, straight setae wider apart on postocular lobe posterior to ocelli. Anterior lobe of thorax with irregular row of tuberculated, short, curved setae on lateral margins and fine, adpressed setae on dorsal surface, posterior lobe with only short, sparse setae. Corium of hemelytron with short, sparse, adpressed setae. Legs with two rows of setigerous tubercles, tibiae with regular rows of tuberculated, stout, sharp setae. Connexival margin of abdomen glabrous.

HEAD. Short conical; maxillary plate apically truncate; scape not reaching apex of clypeus; eye hemispherical in dorsal view, about $1 / 5$ length of head, not attaining ventral margin of head in lateral view; height of anteocular lobe shorter than postocular lobe.

THorax. Antero-lateral paired projections acute, diverging; surface of anterior lobe with low ridges; median pronotal depression contiguous with transverse sulcus; paramedian carina weakly defined; posterior lobe medially weakly rugose; anterior pronotal lobe shorter than posterior lobe, narrower than posterior lobe, anterior lobe lower than posterior lobe in lateral view; paramedian lobe bell-shaped and skewed towards median; scutellum semicircular, scutellar process long, with subacute apex; mesosternite without median irregular tuberculated protrusion between fore and mid coxae.

Hemelytron. Attaining tip of abdomen.

LeGs. Fore femur distinctly incrassate.

ABDOMEN. Elongate ovoid, with rounded terminal margin; connexival margin smooth, posterior margin not elevated.

\section{Male}

Unknown. 


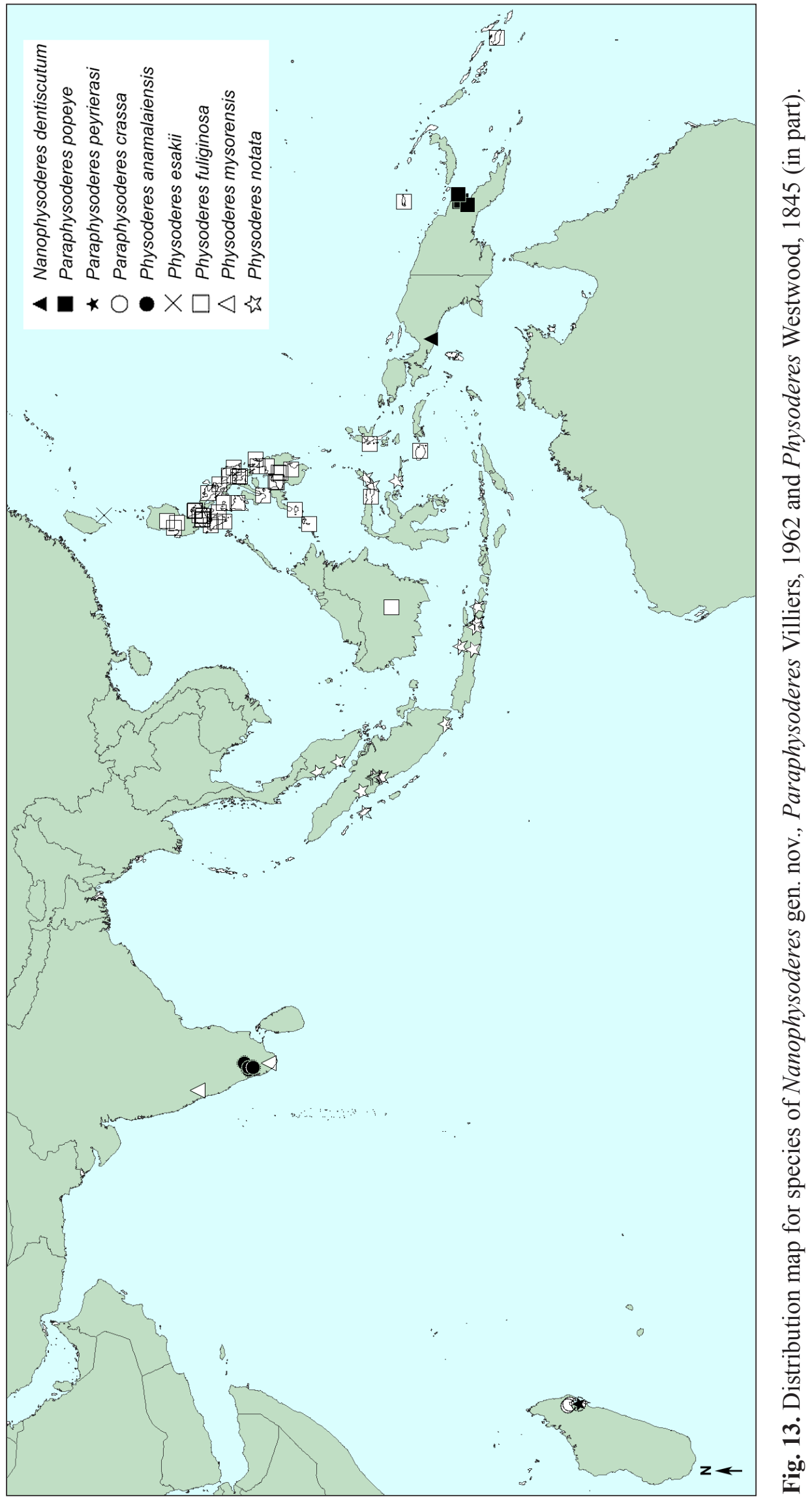




\section{Ecology}

Unknown.

\section{Distribution}

Known only from the locality of the holotype of the type species, which was labelled as "New Guinea".

\section{Remarks}

Based on the phylogeny, $N$. dentiscutum comb. nov. is sister to all other physoderines except for the Neotropical and Afrotropical species. The isolated placement of $N$. dentiscutum comb. nov. in the phylogeny and its distinct morphology warrant the decision to erect a new genus to accommodate this species. This genus is described based on a female specimen as no males are known.

Nanophysoderes dentiscutum (Bergroth, 1906) comb. nov. Figs 10-11, 13; Appendix

Physoderes dentiscutum Bergroth, 1906: 16.

\section{Diagnosis}

As in generic description.

\section{Material examined}

Holotype

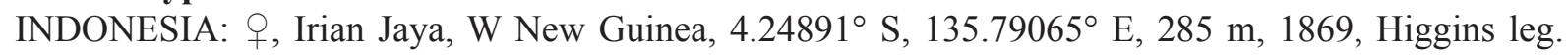
(UCR_ENT 00037370) (ISNB).

\section{Redescription}

As in generic description.

Paraphysoderes Villiers, 1962

Figs 3, 8-9, 13-14; Appendix

\section{Diagnosis}

This genus is recognized among other genera of Physoderinae by its small size $(6.30-7.09 \mathrm{~mm})$, brown to dark brown coloration, the scape surpassing the apex of the clypeus and being thicker than the remaining antennal segments, the obsolete antero-lateral pronotal projection, the rounded lateral margins of the anterior pronotal lobe, the anterior pronotal lobe being level with the posterior lobe, the acute scutellar spine, and the fore tibia bearing a few prominent processes with sharp, stout, setae. It is most similar to Physoderoides Miller (1955a), but is distinguished by the body size, head shape, the maxillary plate not being raised and the lack of antero-lateral pronotal projections.

\section{Type species}

Paraphysoderes crassa Villiers, 1962, by original designation.

\section{Redescription}

\section{Male}

Body Length. Small, total length 6.30-7.09 mm. 


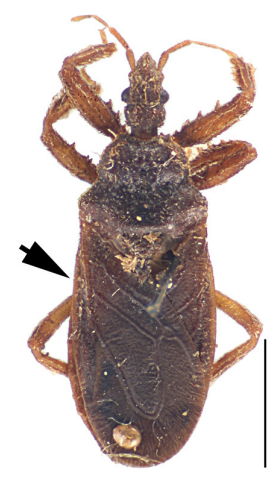

Pa. popeye sp. nov. Holotype UCR_ENT 00073584

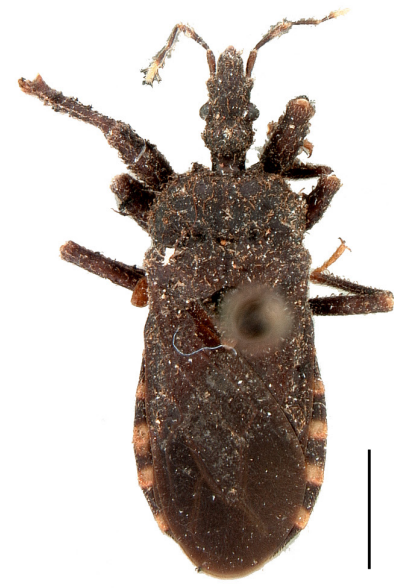

$P$. anamalaiensis sp. nov. UCR_ENT 00046639

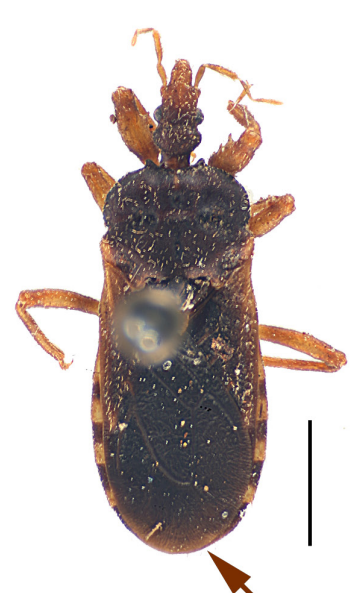

P. azrael

UCR_ENT 00073529

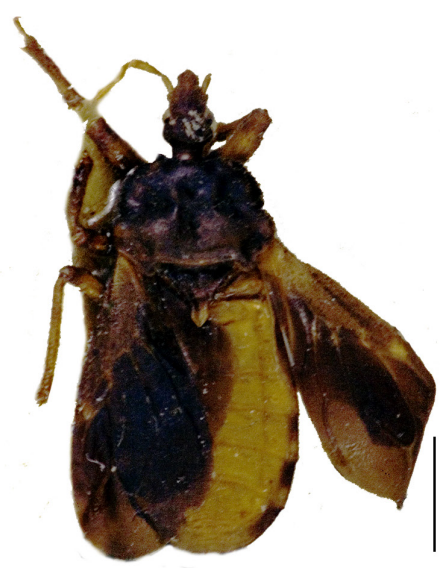

P. azrael

Holotype UCR_ENT 00018531

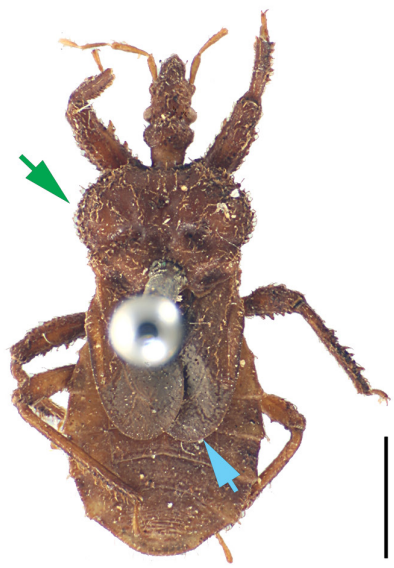

P. brevipennis sp. nov. Paratype UCR_ENT 00069376

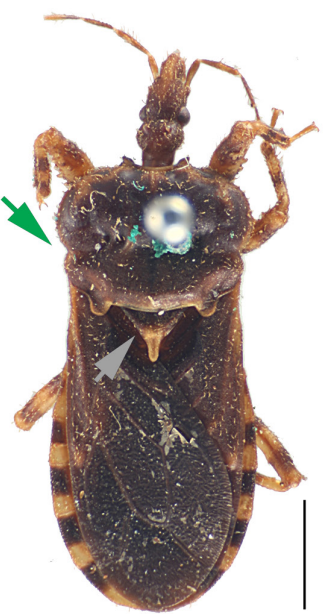

$P$ fuliginosa

Male UCR_ENT 00030978

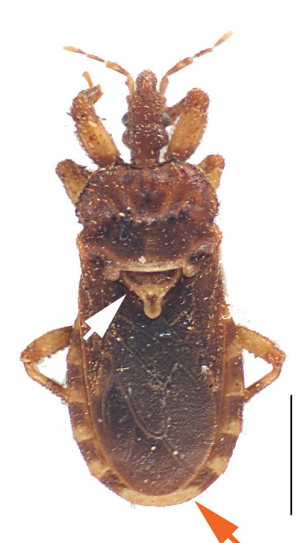

P. curculionis UCR_ENT 00073577

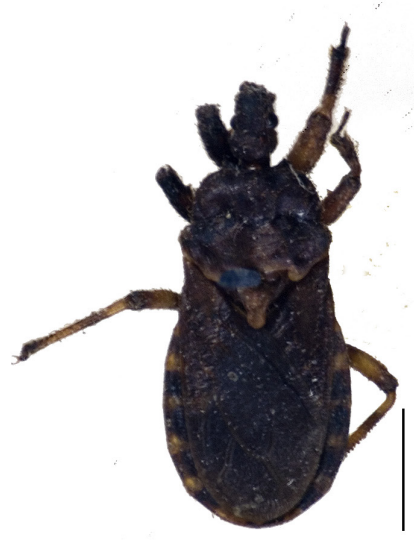

P. curculionis

Paratype UCR_ENT 00018525

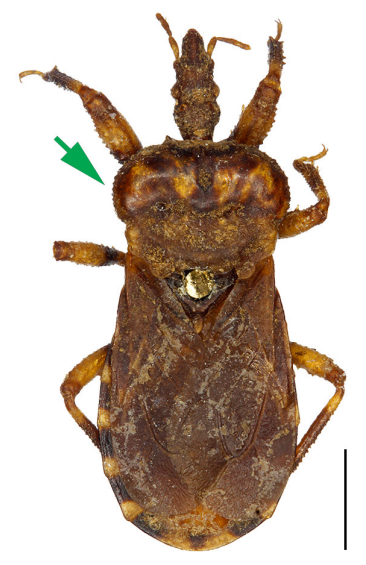

P. esakii Holotype Imaged by L. Cao

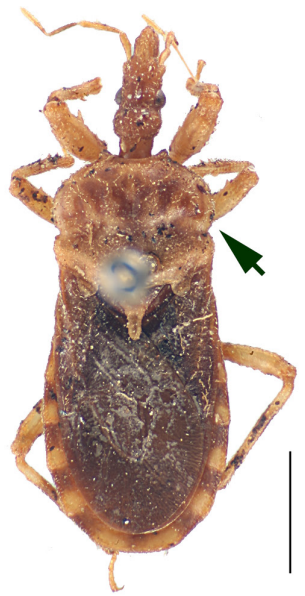

$P$. minime sp. nov.

Holotype UCR_ENT 00030979

Fig. 14. Dorsal habitus images for species of Paraphysoderes Villiers, 1962 and Physoderes Westwood, 1845 (partial). For an explanation of the colored arrows, see keys on page 63 and 66 . Scale bars $=2 \mathrm{~mm}$. 
Coloration (Fig. 13; Paraphysoderes popeye sp. nov.). Yellow-brown to dark brown. Head, pronotum, legs, corium of similar coloration, legs with uniform color, no annulation pattern, connexivum sometimes uniformly colored.

VestituRE. Sparsely setose with tuberculated, curved, short, setae. Surface of anterior pronotal lobe smooth or tuberculated.

HEAD. Short conical; maxillary plate rounded apically; scape surpassing apex of clypeus; eye relatively large, hemispherical or projecting in dorsal view, not reaching ventral margin of head in lateral view; ocelli present; height of anteocular lobe level or shorter than postocular lobe.

ThORAX. Antero-lateral paired projections obsolete; ridges of anterior pronotal lobe almost obsolete; median pronotal depression contiguous with transverse sulcus; paramedian carina weakly defined; length of anterior pronotal lobe variable, narrower than posterior lobe in both sexes, level with posterior lobe in lateral view; parascutellar lobe semicircular or quadrant-shaped, skewed towards median; scutellum triangular, scutellar process long, apex variable; mesosternite with median, irregular, tuberculated protrusion between fore and mid coxae.

Hemelytron. Macropterous, not attaining tip of abdomen.

LEGS. Fore femur distinctly incrassate, fore tibia bearing a few prominent processes with sharp, stout setae; tarsi three-segmented.

AвDOMEN. Ovoid or elongate ovoid, with straight or rounded terminal margin; connexival margin smooth, posterior margin not elevated.

Genitalia. Only examined for $P a$. popeye sp. nov. (see species description below).

\section{Female}

Similar to males, but larger and with wider abdomen.

\section{Ecology}

No information is available for the Madagascan species, while Pa. popeye sp. nov. has been recorded on Pandanus (Pandanaceae).

\section{Distribution}

This genus has a disjunct distribution, with two species occurring in northeastern Madagascar and one species on the eastern edge of Papua New Guinea, on the Huon Peninsula.

\section{Remarks}

Based on the phylogenetic analysis, the new species Paraphysoderes popeye sp. nov. forms a monophyletic clade with $\mathrm{Pa}$. peyrierasi and $\mathrm{Pa}$. crassa. It shares the synapomorphies of the small body size and the fore tibia bearing a few prominent setigerous tubercles. Closer examination also revealed similarities in the shape of the head and pronotum, a similar acute scutellar process and the hemelytron not reaching the tip of the abdomen. This evidence led to classifying this new species as Paraphysoderes, even though this significantly expands the distribution range of this genus, which was previously restricted to Madagascar. 


\section{Key to species of Paraphysoderes}

1. Fore femur longer than mid femur, surpassing apex of clypeus, scutellar process acute and tapered, $\mathrm{Cu}$ and $\mathrm{M}$ veins not parallel, converging basally (Fig. 14, black arrow), Pacific distribution

Pa. popeye sp. nov.

- Fore femur as long as or shorter than mid femur, not surpassing apex of clypeus, scutellar process subacute, $\mathrm{Cu}$ and $\mathrm{M}$ veins parallel, not converging (Fig. 3, grey arrow), restricted to Madagascar

2. Body reddish-brown, scutellum apex and scutellar process straw-colored, connexivum uniformly reddish-brown

Pa. peyrierasi Villiers, 1968

- Body brown, scutellum and scutellar process brown, anterior half of connexivum dark brown, posterior half light brown

Pa. crassa Villiers, 1962

\section{Paraphysoderes popeye sp. nov. urn:1sid:zoobank.org:act:533BD1D8-0A74-4197-B7E9-3CD231BC2F61}

Figs 7-8, 12-13; Appendix

\section{Diagnosis}

This species is recognized among species of Paraphysoderes by its small size, brown to dark brown coloration, the elongate conical head, the scape surpassing the apex of the clypeus, the obsolete anterolateral pronotal projection, the anterior pronotal lobe being level with the posterior lobe, the scutellar spine being acute and tapered, the parascutellar spine being semicircular, the cubital $(\mathrm{Cu})$ vein being angular at the junction of the connecting vein with the first anal vein (1A), the distinctly incrassate fore femur, which is longer than the mid femur, the fore tibia bearing a few prominent processes with sharp, stout, setae, the mid femur with prominent processes with peg-like setae on the anterior surface, and the abdominal spiracles turreted and being located directly ventral to the connexival margin.

\section{Etymology}

The name popeye is a noun in apposition to describe the uniquely enlarged fore-arms of this species that is similar to the fictional cartoon character Popeye the Sailor Man.

\section{Material examined}

\section{Holotype}

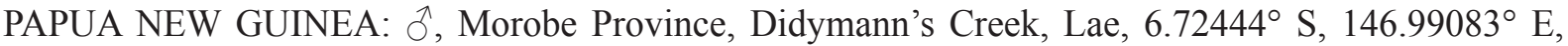
15 m, 30 Apr. 1963, J. Sedlacek leg. (UCR_ENT 00073584) (BPBM).

\section{Paratypes}

PAPUA NEW GUINEA: Morobe Province: 1 , Huon Peninsula Co., Pindiu, 6.44388 ${ }^{\circ}$ S, $147.515^{\circ}$ E, 450 m, 19 Apr. 1963, J. Sedlacek leg. (UCR_ENT 00073624) (BPBM); 1 क, Bulolo, 7.20472 ${ }^{\circ}$ S, $146.63166^{\circ}$ E, 130 m, 30 Aug. 1956, E.J. Ford Jr. leg. (UCR ENT 00073621) (BPBM); 1 ㅇ, same collection data as for holotype (UCR_ENT 00073623) (BPBM); 1 q , Yalu, Lae, $6.5875^{\circ} \mathrm{S}, 146.87666^{\circ} \mathrm{E}$, Dec. 1957, R.W. Paine leg. (UCR_ENT 00069393) (BMNH).

\section{Description}

\section{Male}

Body LENGTH. Small, total length $7.09 \mathrm{~mm}$.

Coloration (Fig. 14). Brown to dark brown. Head brown or dark brown. Scape and pedicel of antenna light brown with brown suffusion, disti- and basiflagellomeres straw-colored. First segment of labium 
brown, second segment basally brown, medially straw-colored, apically brown, third segment brown. Thorax dark brown. Corium of hemelytron dark brown, membrane dark brown. Fore and mid femora and tibiae of legs light brown to brown, tarsi and claws light brown, hind femur dark brown with medial light brown annulation, hind tibia light brown to dark brown, hind tarsus and claw light brown. Abdomen dorsally reddish-orange, ventrally light brown with brown suffusion, connexivum brown with a lighter margin, exposed part of pygophore dark brown.

VestituRe. Sparsely setose. Head with widespread curved setae, ventral surface of postocular lobe with sparse, setigerous tubercles, without pair of long, straight setae on postocular lobe posterior to ocelli. Anterior lobe of thorax with irregular row of tuberculated, short, curved setae on lateral margins and short, setigerous tubercles dispersed on dorsal surface, posterior lobe with short, curved, setigerous tubercles on humeral angle and glabrous on dorsal surface. Corium of hemelytron with short, sparse, adpressed setae. Legs with two rows of spines and setigerous tubercles, tibia with a few prominent tuberculated, stout, sharp setae. Connexival margin of abdomen sparsely setose, without prominent setae.

HEAD. Elongate conical; maxillary plate rounded apically; scape surpassing apex of clypeus; eye hemispherical in dorsal view, about $1 / 5$ length of head, not attaining ventral margin of head in lateral view; height of anteocular lobe level with postocular lobe.

Thorax. Antero-lateral paired projections obsolete; surface of anterior lobe smooth, ridges almost obsolete; median pronotal depression contiguous with transverse sulcus; paramedian carina weakly defined; posterior lobe smooth, dull; anterior pronotal lobe shorter than posterior lobe, narrower than posterior lobe, anterior lobe level with posterior lobe in lateral view, semicircular; scutellum triangular, scutellar process long, apex acute and tapered; mesosternite with median, irregular, tuberculated protrusion between fore and mid coxae.

Hemelytron. Not reaching tip of abdomen.

LEGS. Fore femur distinctly incrassate.

АвDомEN. Elongate ovoid, with straight terminal margin; connexival margin smooth, not undulating, posterior margin not elevated.

GENITALIA. Anterior margin of mediosternite 8 sharply emarginate, without medial apodeme; transverse bridge of pygophore broad, margin of anterior opening rounded, apodeme present, apical margin of posterior opening smooth; cup-like sclerite apically rounded, with sclerotized paired latero-ventral slight protuberances; arms of basal plate parallel to each other; ductifer with sclerotized rounded ring; endosomal struts tube-like, with medial sclerotization and with a T-shaped apex; shape of dorsal phallothecal sclerite subacute with narrow, lateral, band-like prolongations, sclerotized band extended horizontally towards ventral surface of phallosoma.

\section{Female}

Similar in morphology to males, but much larger (7.89 $\mathrm{mm}$ average total length) with wider abdomen ( $2.56 \mathrm{~mm}$ for males, $3.32 \mathrm{~mm}$ average width for females). Because one such female was collected in the same collecting event as the holotype male, these females are here treated as the same species.

\section{Ecology}

This species has been recorded on Pandanus (Pandanaceae). 


\section{Distribution}

This species is distributed in the eastern edge of Papua New Guinea around the Huon Peninsula.

\section{Remarks}

A damaged female specimen from Fiji (not described here), that is most likely not the same species as $P a$. popeye sp. nov. but likely belongs to Paraphysoderes, suggests an even more extended and disjunct distribution of this genus and potential undiscovered diversity in the Pacific region. Note: The current color of the holotype has been altered and is different from the image provided here due to treatment with $\mathrm{KOH}$ solution for dissection of the male genitalia.

\section{Physoderes Westwood, 1845}

Figs 8-9, 13-20; Appendix

\section{Diagnosis}

This genus is recognized among other genera of Physoderinae by the scape reaching the apex of the clypeus, the parascutellar lobe being rounded and skewed towards the median, the males having an enlarged anterior pronotal lobe, wider than or equal to the width of the posterior lobe (except in P. nigripennis sp. nov., P. ractepilosa sp. nov. and P. muluensis sp. nov.), the median pronotal depression not being contiguous with the transverse sulcus (males) and by males having a membranous ductifer. This genus is most similar to Epiroderoides Villiers, 1962, but can be differentiated from it based on the anterior pronotal shape in males and the shape of the parascutellar lobes.

\section{Type species}

Physoderes notata Westwood, 1845, by monotypy.

\section{Redescription}

\section{Male}

Body Length. Size variable, total length 6.08-11.03 mm (Appendix).

Coloration (Figs 14-18). Variable, from straw-colored to dark brown. Head, anterior pronotal ridges, posterior pronotal lobe, legs and corium of similar lighter coloration, anterior pronotal lobe, scutellum and claval region with darker coloration.

VestituRe. Sparsely to densely setose with curved, fine or erect setae, with pair of long, straight setae on posterior margin of postocular lobe (except in P. nigripennis sp. nov. and P. nigroalbus).

HEAD. Elongate or short, conical; maxillary plate most often rounded apically; scape never distinctly surpassing apex of clypeus; eye hemispherical in dorsal view except in P. nigripennis sp. nov. and P. tricolor sp. nov., less than $1 / 5$ length of head and never reaching ventral margin of head in lateral view; ocelli present; height of anteocular lobe shorter than postocular lobe except in P. anamalaiensis sp. nov. and $P$. mysorensis sp. nov.

Thorax. Shape of antero-lateral paired pronotal projection variable; surface of anterior pronotal lobe most often with low ridges; median pronotal depression not contiguous with transverse sulcus except in species without enlarged anterior pronotum; paramedian carina variable; posterior lobe medially rugose; length of anterior pronotal lobe variable, wider and higher than or equal to posterior lobe except in P. nigripennis sp. nov., P. ractepilosa sp. nov. and P. muluensis sp. nov.; parascutellar lobe rounded and sometimes skewed towards median, except in P. brevipennis sp. nov.; scutellum rounded triangular 
except in P. azrael and P. curculionis, length of scutellar process and shape of apex variable; mesosternite with median irregular tuberculated protrusion between fore and mid coxae.

Hemelytron. Macropterous, never surpassing tip of abdomen.

LEGS. Fore femur distinctly incrassate, tarsi three-segmented.

Abdomen. Elongate ovoid except in P. brevipennis sp. nov. and P. curculionis, with rounded terminal margin except in $P$. ractepilosa sp. nov.; shape of connexival margin variable, posterior margin only slightly elevated in P. nigripennis sp. nov.

Genitalia. Variable (see species descriptions for details).

\section{Female}

Females with anterior pronotal lobe narrower and lower than posterior lobe, with median pronotal depression contiguous with transverse depression.

\section{Ecology}

Species from this genus are found in a variety of living and dead plant materials and in the undergrowth. Specimens have been collected from pitfall traps and carrion traps and have been found at up to $1200 \mathrm{~m}$ elevation.

\section{Distribution}

This genus is the most widespread of the subfamily, and species distributions cover the entire known range of Physoderinae in the Old World except in the Afrotropics. Species can be found in Madagascar, the Indian subcontinent, peninsular Malaysia, Sumatra, Java, Borneo, the Philippine archipelago, Sulawesi, Papua New Guinea, the Solomon Islands and the Fiji Islands.

\section{Remarks}

Physoderes notata is the type species of Physoderes by monotypy and the clade that includes $P$. notata and $P$. nigripennis sp. nov. derived from the phylogenetic analysis above is recognized as the revised Physoderes.

\section{Key to species of Physoderes}

1. Scutellum semicircular (Fig. 14, white arrow), transverse bridge of pygophore narrow (Fig. 8, yellow arrow)

- Scutellum triangular (Fig. 14, grey arrow) transverse bridge of pygophore broad (Fig. 8, dark blue arrow)

2. Small $(7.23-7.90 \mathrm{~mm})$, anterior pronotal lobe longer than posterior lobe, hemelytron not reaching tip of abdomen, abdomen ovoid, connexivum slightly undulating (Fig. 14, orange arrow) P. curculionis China, 1935

- Of medium size $(8.14-8.83 \mathrm{~mm})$, anterior and posterior pronotal lobes equal in length, hemelytron reaching tip of abdomen, abdomen elongate ovoid, connexivum smooth, not undulating (Fig. 14, brown arrow) P. azrael Kirkaldy, 1905

3. Anterior pronotal lobe narrower than posterior lobe in males (Fig. 15, black arrows) ......4

- Anterior pronotal lobe wider than posterior lobe in males (Figs 14, 15, green arrows) ....7 
4. Fore femur slender, slightly incrassate, hemelytron not reaching tip of abdomen (Fig. 15, orange arrows)

- Fore femur distinctly incrassate, hemelytron reaching tip of abdomen (Fig. 15, brown arrow) ....6

5. Small-medium size (6.99-8.21 mm), without long, erect setae (Fig. 15, light purple arrow), scape reaching apex of clypeus, paramedian carina weakly defined, anterior pronotal lobe level with posterior lobe in lateral view, parascutellar lobe rounded and skewed towards median

P. muluensis sp. nov.

- Medium-large size (8.32-10.19 mm), body covered with long, erect setae (Fig. 15, purple arrow), scape not reaching apex of clypeus, paramedian carina strongly defined, anterior pronotal lobe lower than posterior lobe in lateral view, parascutellar lobe rounded and straight

P. ractepilosa $\mathrm{sp}$. nov.

6. Head elongate and conical, maxillary plate truncate apically, scape reaching apex of clypeus, eye distinctly projecting in dorsal view, antero-lateral pronotal projection truncate, hemelytron entirely black (Fig. 15, brown arrow)

P. nigripennis sp. nov.

- Head short and conical, maxillary plate rounded apically, scape not reaching apex of clypeus, eye hemispherical in dorsal view, antero-lateral pronotal projection acute and diverging, basal half of hemelytron dark brown, apical half off-white (Fig. 15, red arrow)

P. nigroalbus Breddin, 1903

7. Brachypterous (Fig. 14, light blue arrow)

P. brevipennis sp. nov.

- Macropterous 8

8. Parascutellar lobe rounded and skewed towards median (Fig. 15, light blue arrow) ...........9

- Parascutellar lobe rounded and straight (Fig. 15, dark blue arrow) .....................................10

9. Anterior pronotal lobe shorter than posterior lobe, lobes level with each other in lateral view, hemelytral membrane basally dark brown, apically off-white P. tricolor sp. nov.

- Length of anterior pronotal lobe equal to that of posterior lobe, anterior lobe higher than posterior lobe in lateral view, membranous portion of hemelytron uniformly brown

P. notata Westwood, 1845

10. Height of anteocular lobe shorter than that of postocular lobe, scutellar process long and slender (Fig. 14, grey arrow)

- Height of anteocular and postocular lobes equal, scutellar process broad (Fig. 15, white arrow)

11. Hemelytron reaching tip of abdomen

P. fuliginosa (Stål, 1870)

- Hemelytron short, not reaching tip of abdomen

12. Large $(10.5 \mathrm{~mm})$, scape reaching apex of clypeus, anterior pronotal lobe distinctly wider than posterior lobe (Fig. 14, green arrow)

P. esakii Cao et al., 2011

- Of medium size $(8.10-9.03 \mathrm{~mm})$, scape not reaching apex of clypeus, anterior pronotal lobe marginally wider than posterior lobe (Fig. 14, dark green arrow) P. minime sp. nov.

13. Large (10.52-10.96 mm), males with apodeme on mediosternite 8, transverse bridge of pygophore broad (Fig. 8, dark blue arrow), margin of anterior opening of pygophore rounded in lateral view, with sclerotized, angular ductifer P. mysorensis sp. nov. 
HWANG W.S. \& WEIRAUCH C., Phylogeny and revision of Physoderes and allied genera

- Of medium size (8.91-9.82 mm), males without apodeme on mediosternite 8, transverse bridge of pygophore narrow (Fig. 8, yellow arrow), margin of anterior opening of pygophore angular in lateral view, with membranous ductifer P. anamalaiensis sp. nov.

\author{
Physoderes anamalaiensis sp. nov. \\ urn:1sid:zoobank.org:act:C302D0E6-40FC-446C-A044-EBFD1A76F7D2
}

Figs 8-9, 13-14, 17; Appendix

\title{
Diagnosis
}

This species is recognized among species of Physoderes by the scape reaching the apex of the clypeus, the small eye, the acute and anteriorly oriented antero-lateral projection of the anterior pronotal lobe, the wide anterior pronotal lobe, which is equal to or wider than the posterior lobe in males and only slightly narrower than the posterior lobe in females, the rounded parascutellar lobe, the dark brown scutellum with the apex thickened and raised, the straw-colored, rounded and short scutellar process, and the hemelytron reaching the tip of the abdomen. This species is most similar to P. mysorensis sp. nov., but is differentiated by the smaller size $(8.91-9.82 \mathrm{~mm})$, having no apodeme on mediosclerite 8 , the narrow transverse bridge of the pygophore, and the margin of the anterior opening of the pygophore being angular in lateral view and with a membranous ductifer.

\section{Etymology}

The name anamalaiensis is a noun in apposition as a tribute to the type locality Anamalai Hills, Tamil Nadu, India.

\section{Material examined}

Holotype

INDIA: ${ }^{\lambda}$, Tamil Nadu, Madras Co., Anamalai Hills, Cinchona, $10.28228^{\circ} \mathrm{N}, 76.97999^{\circ} \mathrm{E}, 1067 \mathrm{~m}$, Sep. 1959, P.S. Nathan leg. (UCR_ENT 00046637) (AMNH).

\section{Paratypes}

INDIA: Tamil Nadu: Madras Co., Anamalai Hills: 1 đે, $10.74944^{\circ}$ N, $77.29888^{\circ}$ E, 1067 m, May 1956, P.S. Nathan leg. (UCR_ENT 00068925) (AMNH); 2 $\widehat{\partial}$, same collection data as preceding but Apr. 1957

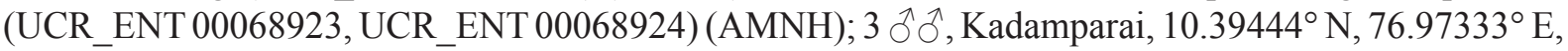
1067 m, May 1963, P.S. Nathan leg. (UCR_ENT 00068918-UCR_ENT 00068920) (AMNH).

\section{Other material}

INDIA: Tamil Nadu, Madras Co., Anamalai Hills: 1 đิ, $10.74972^{\circ}$ N, $77.29972^{\circ}$ E, 344 m, May 1957, P.S. Nathan leg. (UCR_ENT 00068922) (AMNH); 2 ồ, $10.38277^{\circ} \mathrm{N}, 76.92944^{\circ} \mathrm{E}, 1372 \mathrm{~m}$, Sep. 1946, P.S. Nathan leg. (UCR_ENT 00046638, UCR_ENT 00046639) (CAS); 1 \%, same collection data as preceding but 21 Jun. $194 \overline{6}$ (UCR ENT 00046622) (CAS); 1 ㅇ, $10.74944^{\circ} \mathrm{N}, 77.29888^{\circ} \mathrm{E}, 1067 \mathrm{~m}$, May 1964, P.S. Nathan leg. (UCR_ENT 00068934) (AMNH); 2 juvs, same collection data as preceding but May 1957 (UCR_ENT 00068938, UCR_ENT 00068939) (AMNH); 1 , same collection data as preceding but Apr. 1957 (UCR_ENT 00068933) (AMNH); 3 juvs, same collection data as preceding (UCR ENT 00068935-UCR ENT 00068937) (AMNH); 1 $\sigma^{\lambda}$, same collection data as for holotype (UCR ENT 00046636) (CAS); 3 9 , , same collection data as for holotype (UCR ENT 00046642UCR ENT 00046644) (CAS); 1 ㅇ, same collection data as for holotype but Apr. 1959 (UCR ENT 00046645) (CAS); 1 9, same collection data as for holotype but May 1957 (UCR ENT 00068929) (AMNH); 2 우, same collection data as preceding (UCR ENT 00046640, UCR ENT 00046641) (CAS); 1 ' , Cinchona, $10.74944^{\circ}$ N, $77.29861^{\circ} \mathrm{E}, 344 \mathrm{~m}$, May 1957, P.S. Nathan leg. (UCR ENT 00068930) (AMNH); 2 우, same collection data as preceding but Apr. 1956 (UCR_ENT 00068926, UCR_ENT 00068927) (AMNH); 1 juv., same collection data as preceding (UCR_ENT 00068928) 
(AMNH); 2 + 9 , same collection data as preceding but Apr. 1957 (UCR_ENT 00068931, UCR_ENT

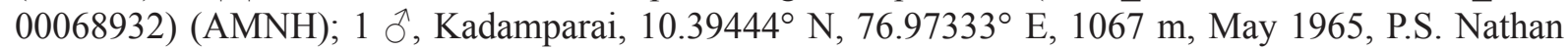
leg. (UCR_ENT 00068921) (AMNH); 1 đo, Anamalais, $10.36667^{\circ} \mathrm{N}, 77.125^{\circ} \mathrm{E}, 914 \mathrm{~m}, 25$ Jan. 1912, K. Pandal leg. (UCR_ENT 00069254) (BMNH).

\section{Description}

\section{Male}

Body LENGTH. Medium, total length $9.27 \mathrm{~mm}, \mathrm{SD} \pm 0.36$ (Appendix).

Coloration (Figs 14, 17). Dark brown. Head dark brown. Scape of antenna brown, pedicel brown basally, straw-colored apically, basiflagellomere brown, distiflagellomere basally brown, apically straw-colored. First segment of labium brown, second segment basally brown, medially straw-colored, apically brown, third segment brown. Pronotum of thorax dark brown, scutellum dark brown, scutellar process strawcolored, pleuron dark brown, sternum dark brown. Corium of hemelytron dark brown, membrane dark brown. Legs dark brown. Abdomen dorsally yellowish-orange, ventrally dark brown with suffusion of straw-color and brown, anterior half of connexivum dark brown, posterior half straw-colored, exposed part of pygophore dark brown.

Vestiture. Sparsely setose. Head with widespread curved setae, ventral surface of postocular lobe with sparse, setigerous tubercles, with pair of long, straight setae on postocular lobe posterior to ocelli. Anterior lobe of thorax with irregular row of tuberculated, short, curved setae on lateral margins and short, setigerous tubercles dispersed on dorsal surface, posterior lobe with short, curved setae on humeral angle and sparsely distributed along dorsal surface. Corium of hemelytron with short, curved setae. Legs with two rows of spines and setigerous tubercles, tibiae with regular rows of tuberculated, stout, sharp setae. Connexival margin of abdomen with no prominent setae.

HEAD. Elongate conical; maxillary plate rounded apically; scape reaching apex of clypeus; eye hemispherical in dorsal view, less than $1 / 5$ length of head; height of anteocular lobe level with postocular lobe.

THORAX. Antero-lateral paired projections acute; surface of anterior lobe with low ridges; median pronotal depression not contiguous with transverse sulcus; paramedian carina weakly defined; anterior pronotal lobe longer than posterior lobe, wider than or equal in width to posterior lobe, higher than posterior lobe in lateral view; parascutellar lobe rounded; scutellar process short, apex rounded.

Hemelytron. Reaching tip of abdomen.

LeGs. Same as genus description.

ABDomEn. Connexival margin slightly undulating, posterior margin not elevated.

Genitalia. Anterior margin of mediosternite 8 undulating, without medial apodeme; transverse bridge of pygophore narrow, margin of anterior opening angular, apodeme present, apical margin of posterior opening smooth; cup-like sclerite apically rounded and rim ventrally sclerotized; arms of basal plate converging; ductifer membranous; endosomal struts conical, with subacute apex, divided into two arms basally; shape of dorsal phallothecal sclerite subacute with lateral broad, plate-like prolongations, short, rounded lateral plates.

\section{Female}

Similar to males except with anterior pronotal lobe slightly narrower than posterior lobe and median pronotal depression contiguous with transverse sulcus. 


\section{Ecology}

Nothing is known about the biology of this species.

\section{Distribution}

This species is known only from the area around the type locality in the Anamalai Hills, Madras, Tamil Nadu, India.

\section{Remarks}

This species possesses the enlarged anterior pronotal lobe characteristic of Physoderes along with the associated pronotal modifications, and is thus placed in this genus. The females possess an enlarged anterior pronotal lobe, although not as exaggerated as that of the males, which is quite unique. The species is most likely closely related to the other Physoderes species native to India, P. mysorensis sp. nov., described below.

\section{Physoderes azrael Kirkaldy, 1905}

Figs 8-9, 14, 17, 20; Appendix

Physoderus [sic] azrael Kirkaldy, 1905: 339.

\section{Diagnosis}

This species is recognized among other species of Physoderes by the head being anteriorly light brown and posteriorly brown, the pronotum dark brown straw-colored or with a light brown humeral tubercle, the posterior margin, parascutellar lobe, scutellar process and base of the corium light brown, the short and conical head, the scape reaching the apex of the clypeus, the anterior pronotal lobe being equal to or slightly narrower than the posterior lobe, the parascutellar lobe being rounded and skewed towards the median, the semicircular scutellum, the spatulate and apically rounded scutellar process, the pronotum flattened in lateral view and the hemelytron reaching the tip of the abdomen. In the male genitalia, the following features are also diagnostic: the extremely narrow transverse bridge of the pygophore and the apically truncate endosomal struts, which are basally divided into two arms converging medially to form basally a ridge. This species is most similar to P. curculionis but can be differentiated by the coloration, elevation of the pronotum, shape of the abdomen and shape of the endosomal struts in males.

\section{Material examined}

Holotype

PAPUA NEW GUINEA: $\widehat{\jmath}$, East New Britain Province, $5.76277^{\circ} \mathrm{S}, 151.1375^{\circ} \mathrm{E}$, date unknown, Willey leg. (UCR_ENT 00018531) (BMNH).

\section{Other material}

FIJI: 1 juv., Ovalau, Andubangda, $17.64277^{\circ}$ S, $178.74944^{\circ}$ E, 305 m, 18 Jul. 1938, E.C. Zimmerman leg. (UCR_ENT 00073576) (BPBM); 1 juv., Viti Levu, Nadarivatu Co., 4 mi. S of Nadarivatu, $17.51^{\circ} \mathrm{S}$, $177.91888^{\circ}$ E, 732 m, 9 Sep. 1938, Y. Kondo leg. (UCR_ENT 00073569) (BPBM); 2 juvs, Nadarivatu, $17.51^{\circ} \mathrm{S}, 177.91888^{\circ} \mathrm{E}, 1067 \mathrm{~m}, 5$ Sep. 1938, Y. Kondo leg. (UCR ENT 00073570, UCR ENT 00073572) (BPBM); 1 juv., Nadarivatu, $17.51^{\circ} \mathrm{S}, 177.91888^{\circ}$ E, 823 m, 7 Sep. 1938, Y. Kondo leg.

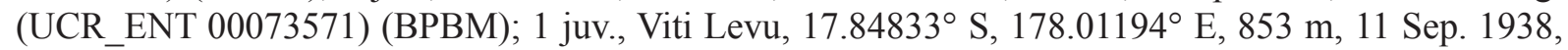
E.C. Zimmerman leg. (UCR_ENT 00073568) (BPBM); 1 juv., Belt Road, 16-18 mi. W of Suva, $18.015^{\circ}$ S, $178.38388^{\circ}$ E, 22 Sep. 1938, Y. Kondo leg. (UCR_ENT 00073575) (BPBM); 1 juv., Mt Victoria, train from Navai, $17.61638^{\circ} \mathrm{S}, 178.01222^{\circ} \mathrm{E}, 600 \mathrm{~m}, 2$ Jul. 1958, B. Malkin leg. (UCR_ENT 00073573) (BPBM); 1 juv., Navai, $17.61638^{\circ}$ S, $177.97694^{\circ}$ E, Jan. 1951, N.L.H. Krauss leg. (UCR_ ENT 00073574) (BPBM). 


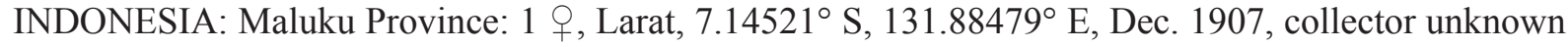
(UCR_ENT 00046675)(CAS). - Papua Province: 1 \&,Hollandia, Neth. Ind-Amer. (Jayapura), $2.54138^{\circ} \mathrm{S}$, $140.71361^{\circ} \mathrm{E}$, Jul. 1938, L.J. Toxopeus leg.(UCR_ENT 00023997)(RMNH); 1 + , Maffin Bay, $2.09222^{\circ} \mathrm{S}$, $139.01472^{\circ}$ E, Jun. 1944, E.S. Ross (UCR_ENT 00046670) (CAS); 1 त, same collection data as preceding but Sep. 1944 (UCR_ENT 00046659)(CAS). - West Papua Province: 1 ○, Vogelkop, Sucumi Camo, near head of Ransiki River, $1.5^{\circ} \mathrm{S}, 132.5^{\circ} \mathrm{E}, 300 \mathrm{~m}, 6$ Aug. 1957, D.E. Hardy leg. (UCR_ENT 00073538) (BPBM).

PAPUA NEW GUINEA: Bougainville Province: $1{ }^{\lambda}$, Buin, $6.81361^{\circ} \mathrm{S}, 155.73194^{\circ} \mathrm{E}, 29 \mathrm{~m}, 31$ May 1956, J.L. Gressitt leg. (UCR_ENT 00073536) (BPBM); 3 §ôे, Kieta, $6.23638^{\circ}$ S, $155.64388^{\circ}$ E, 31 May 1960, R.W. Paine leg. (UCR_ENT 00069325-UCR_ENT 00069327); 4 우, same collection

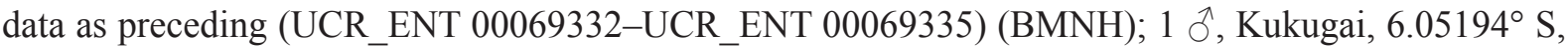
$155.19194^{\circ}$ E, 150 m, Dec. 1960, W.W. Brandt leg. (UCR_ENT 00073535) (BPBM); 1 o, same collection data as preceding (UCR_ENT 00073553) (BPBM). - East New Britain Province: 3 우우, Gazelle Peninsula, Gaulim, $4.45^{\circ} \mathrm{S}, 152.08333^{\circ} \mathrm{E}, 130 \mathrm{~m}, 23-28$ Oct. 1962, J. Sedlacek leg. (UCR ENT 00073542-UCR_ENT 00073544) (BPBM); 1 q, Gazelle Peninsula, Upper Warangoi, Illugi, 4.71472 ${ }^{\circ}$ S, $151.97944^{\circ}$ E, 15 Dec. 1962, J. Sedlacek leg. (UCR_ENT 00073567) (BPBM); 1 ồ, Gazelle Peninsula, Upper Warangoi, Illugi, 4.48333 ${ }^{\circ} \mathrm{S}, 152.15^{\circ}$ E, $230 \mathrm{~m}, 8-11$ Dec. 1962, J. Sedlacek leg. (UCR ENT 00073520) (BPBM); 2 q 9 , same collection data as preceding (UCR ENT 00073565,

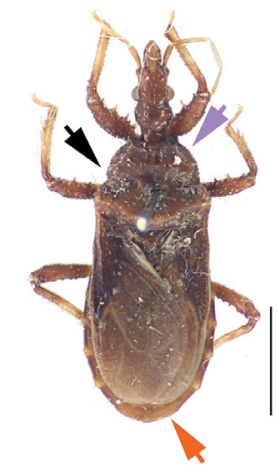

P. muluensis sp. nov. Holotype UCR_ENT 00069405

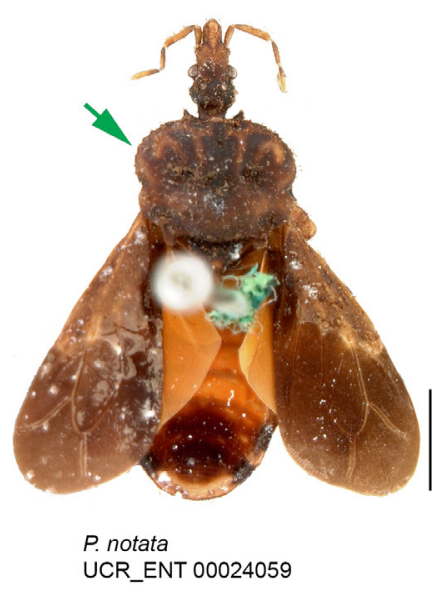

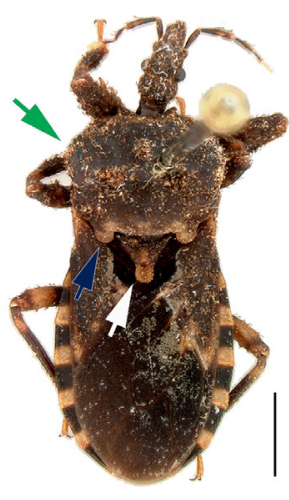

P. mysorensis sp. nov. Holotype UCR_ENT 00068944

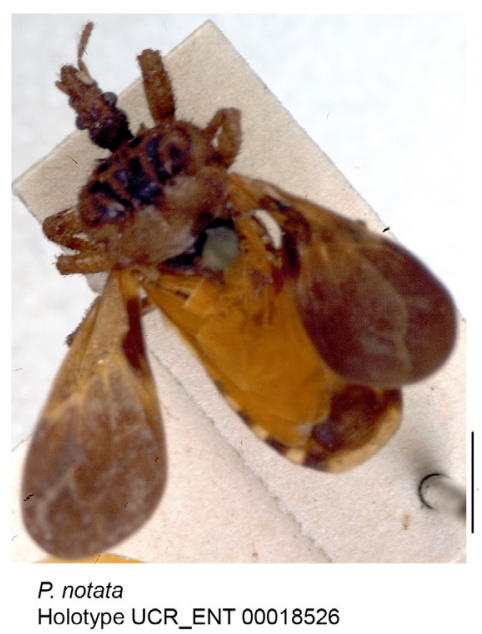

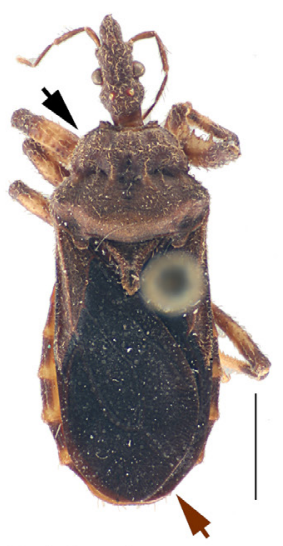

P. nigripennis sp. nov. Paratype UCR_ENT 00014055
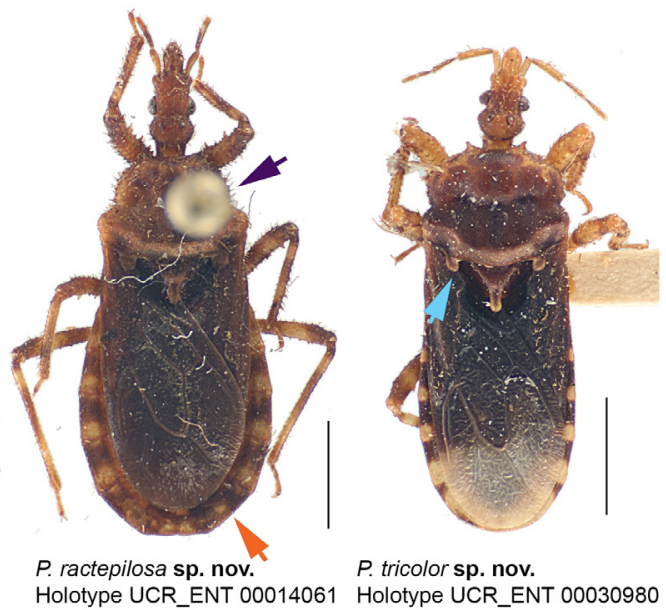

Fig. 15. Dorsal habitus images for species of Physoderes Westwood, 1845 (partial). For an explanation of the colored arrows, see key on page 66. Scale bars $=2 \mathrm{~mm}$. 


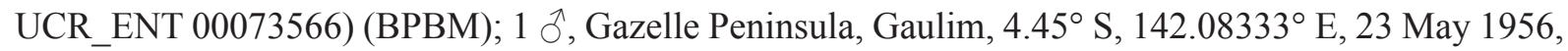
J.L. Gressitt leg. (UCR_ENT 00073523); 1 9, same collection data as preceding (UCR_ENT 00073541) (BPBM); 1 \%, Gazelle Peninsula, Gaulim, 4.44472 ${ }^{\circ} \mathrm{S}, 152.08444^{\circ} \mathrm{E}, 140 \mathrm{~m}, 21-27$ Oct. 1962, J. Sedlacek leg. (UCR_ENT 00073540)(BPBM); 3 $\widehat{\partial}$ ô, same collection data as preceding but 19-20 Nov. 1962 (UCR_ENT 00073516-UCR_ENT 00073518)(BPBM); 1 ôn, Karavat, $4.35194^{\circ} \mathrm{S}, 152.04194^{\circ} \mathrm{E}$, Jul. 1957, R.W. Paine leg. (UCR_ENT 00069324) (BMNH); 1 q, Keravat, $4.35^{\circ} \mathrm{S}, 152.03334^{\circ} \mathrm{E}$, 30 m, 2 Apr. 1956, E.J. Ford Jr leg. (UCR_ENT 00073562) (BPBM); 2 $q$, Kerawat, Gazelle Peninsula,

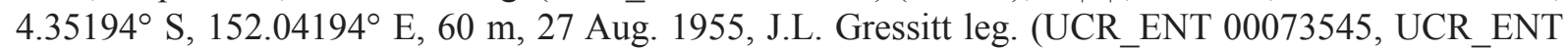

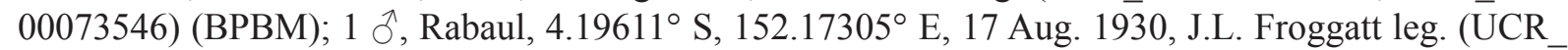
ENT 00046662)(CAS); 1 q, same collection data as preceding but 17 May 1932 (UCR_ENT 00046669) (CAS); 1 ô, Rabaul, $4.175^{\circ}$ S, $152.23083^{\circ}$ E, 4 Jul. 1959, J.L. Gressitt leg. (UCR_ENT 00073519); 1 , same collection data as preceding (UCR_ENT 00073559) (BPBM); 1 \%, near Rabaul, $4.175^{\circ} \mathrm{S}$, $152.24805^{\circ} \mathrm{E}, \mathrm{Feb} .1929$, collectorunknown(UC̄R_ENT 00046668)(CAS); 1 q, JaquinotBay, $5.54638^{\circ} \mathrm{S}$, $151.51722^{\circ}$ E, 3 Dec. 1969, J.E. Tobler leg. (UCR_ENT 00046672) (CAS); 1 o, Wunung Plains, Jacquinot Bay, 5.56472 ${ }^{\circ} \mathrm{S}, 151.57111^{\circ} \mathrm{E}, 30$ Apr. 1956, J.L. Gressitt leg. (UCR_ENT 00073560) (BPBM); 1 ô, Malmalwan-Vunakanau, Gazelle Peninsula, $4.6667^{\circ} \mathrm{S}, 152^{\circ} \mathrm{E}, 17$ May 1956, J.L Gressitt leg. (UCR_ENT 00073521) (BPBM). - West New Britain Province: $1 \hat{\delta}$, Talasea, Narunageru Road, $5.53916^{\circ} \mathrm{S}, 150.13555^{\circ} \mathrm{E}, 22$ Nov. 1969, J.E. Tobler leg. (UCR_ENT 00046663) (CAS); 1 ๙ึ, Linga Linga Plantation, W of Willaumez Peninsula lm. [?], 5.79944 ${ }^{\circ} \mathrm{S}, 149.38083^{\circ} \mathrm{E}, 13$ Apr. 1956, J.L. Gressitt leg. (UCR_ENT 00073522) (BPBM); 1 क, Volupai, Willaumez Peninsula, 5.26916 ${ }^{\circ} \mathrm{S}, 149.97638^{\circ} \mathrm{E}$, 100 m, 18 Apr. 1956, J.L. Gressitt leg. (UCR_ENT 00073561) (BPBM). - New Ireland Province: 1 , Camp Bishop, $12 \mathrm{~km}$ up Kait River, 240 m, 7 Jul. 1956, E.J. Ford Jr leg. (UCR_ENT 00073564)

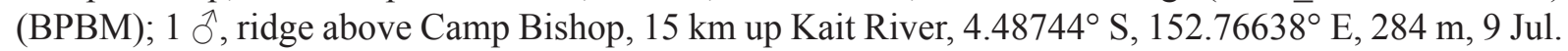
1956, J.L. Gressitt leg. (UCR_ENT 00073539) (BPBM); 1 q, same collection data as preceding (UCR ENT 00073563) (BPBM); $2 \hat{\partial^{\lambda}} \hat{o}$, Wana Wana, $4.52666^{\circ} \mathrm{S}, 152.40555^{\circ} \mathrm{E}$, Nov. 1960, R.W. Paine leg. (UCR_ENT 00069322, UCR_ENT 00069323) (BMNH). - Madang Province: 1 ð , Madang, 5.23361 S, $145.78888^{\circ}$ E, Sep. 1957, R.W. Paine leg. (UCR_ENT 00069293) (BMNH). - Milne Bay Province: 1 ơ, Woodlark Island Co., Kulumadau Hill Mar., $9.05^{\circ}$ S, $152.71667^{\circ}$ E, 25 Feb. 1957, W.W. Brandt leg. (UCR_ENT 00073537) (BPBM). - Morobe Province: 1 q, Huon Penninsula Co., Finschhafen, $6.55527^{\circ} \mathrm{S}, 147.17361^{\circ} \mathrm{E}, 2$ May 1944, E.S. Ross leg. (UCR ENT 00046671) (CAS); 1 đ, 18 Nov.

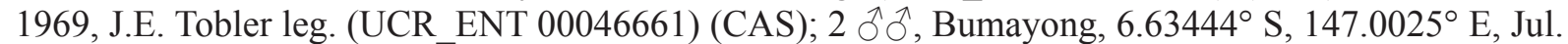
1957, R.W. Paine leg. (UCR_ENT 00069292, UCR_ENT 00069316) (BMNH); 1 q, same collection data as preceding (UCR_ENT 00069304) $(\mathrm{BMNH}) ; 1$, same collection data as preceding but Sep. 1957 (UCR_ENT 00069303) (BMNH); 5 우, Gurakor, 6.73972 ${ }^{\circ} \mathrm{S}, 146.615^{\circ} \mathrm{E}, 610$ m, Jul. 1957, R.W. Paine leg. (UCR_ENT 00069309, UCR_ENT 00069310, UCR_ENT 00069329-UCR_ENT 00069331) (BMNH); $3 \delta^{\lambda} \hat{\sigma}^{-}$, same collection data as preceding (UCR_ENT 00069317-UCR_ENT 00069319)

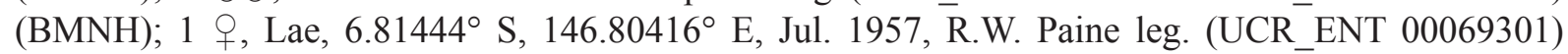

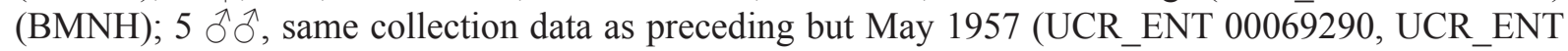
00069291, UCR_ENT 00069294, UCR_ENT 00069314, UCR_ENT 00069321) (BMNH); 6 우, same collection data as preceding (UCR_ENT 00069296-UCR_ENT 00069300, UCR_ENT 00069308) $(\mathrm{BMNH}) ; 3$ 우, same collection data as preceding but date only as 1957 (UCR_ENT 00069305-UCR_ ENT 00069307) (BMNH); $1 \hat{\jmath}$, same collection data as preceding (UCR_ENT 00069315) (BMNH); $1 \mathrm{o}^{\AA}$, Sio, N coast, $5.95333^{\circ} \mathrm{S}, 147.3925^{\circ} \mathrm{E}, 600 \mathrm{~m}, 24 \mathrm{Jul}$. 1956, E.J. Ford Jr leg. (UCR_ENT 00073524) (BPBM); 1 q, Yalu, Lae, $6.5875^{\circ} \mathrm{S}, 146.87666^{\circ}$ E, Apr. 1957, R.W. Paine leg. (UCR_ENT 00069311); $1 \mathrm{O}^{\lambda}$, same collection data as preceding (UCR_ENT 00069320) $(\mathrm{BMNH}) ; 1$ , Rooke Island (= Umboi Island), $5.71972^{\circ} \mathrm{S}, 147.71666^{\circ} \mathrm{E}$, Jan. 1957, R.W. Paine leg. (UCR_ENT 00069313) (BMNH).

SOLOMON ISLANDS: Central Province: 1 ว , Nggela Hagalo, $9.06638^{\circ} \mathrm{S}, 160.21138^{\circ} \mathrm{E}, 88 \mathrm{~m}, 25$ May 1936, R.A. Lever leg. (UCR_ENT 00069328) (BMNH). - Choiseul Island: 1 q, Kolombangara River, $7.05166^{\circ} \mathrm{S}, 156.95027^{\circ} \mathrm{E}, 60 \mathrm{~m}, 20$ Mar. 1964, P. Shanahan leg. (UCR_ENT 00073557) (BPBM). 


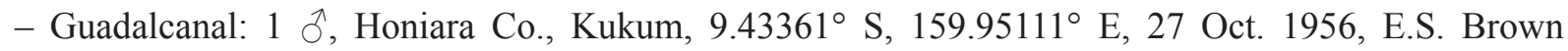
leg. (UCR_ENT 00069349) (BMNH); 1 q, $9.6 \mathrm{~km}$ SE of Honiara, Lunga River bridge, $9.49471^{\circ} \mathrm{S}$, $160.01181^{\circ}$ E, 2 Jun. 1960, C.W. O’Brien leg. (UCR_ENT 00073550) (BPBM); 2 q $q$, Berande, $9.49222^{\circ} \mathrm{S}, 160.17833^{\circ} \mathrm{E}$, Nov. 1931, R. Lever leg. (UCR_ENT 00046665, UCR_ENT 00046666)

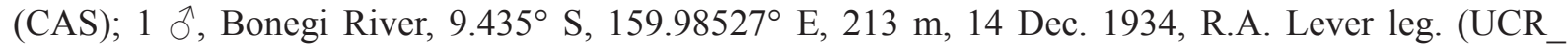
ENT 00069348) (BMNH); $10^{\top}$, Guadalcanal Lavoro, $9.57722^{\circ} \mathrm{S}, 160.14555^{\circ} \mathrm{E}, 18$ Feb. 1934, H.T. Pagden leg. (UCR_ENT 00046660) (CAS); 1 q, Kukum, 9.48916 S, 160.16944 E, Nov. 1931, R.J.A.W. Lever leg. (UCR_ENT 00046674) (CAS); 2 ふ઼, Kukum, 29 Oct. 1963, P. Greenslade leg. (UCR_ENT 00069345, UCR_ENT 00069351); 4 우, same collection data as preceding (UCR_ENT

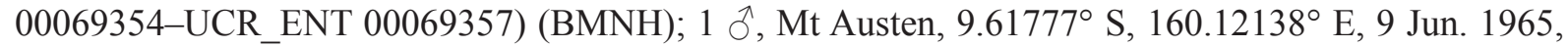
P. Greenslade leg. (UCR_ENT 00069344) (BMNH); 1 ô, same locality as preceding, 9 Jul. 1963, P. Greenslade leg. (UCR_ENT 00069336) (BMNH); 3 ๙ $\widehat{\jmath}$, Mt Austen, $9.55472^{\circ} \mathrm{S}, 160.10666^{\circ} \mathrm{E}$, 305 m, 25 Feb. 1963, P. Greenslade leg. (UCR_ENT 00069341-UCR_ENT 00069343) (BMNH); 2 우, same collection data as preceding (UCR_ENT 00069361, UCR_ENT 00069362) (BMNH); 1 , same collection data as preceding but 19 Jun. 1963 (UCR_ENT 00069367) (BMNH); 1 o, same

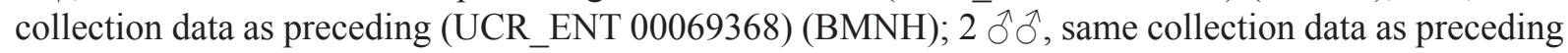
but 11 Feb. 1963 (UCR_ENT 00069337, UCR_ENT 00069338) (BMNH); 1 ô, same collection data as preceding but 23 Jun. 1963 (UCR_ENT 00069339) (BMNH); 1 ô, same collection data as preceding but 4 Mar. 1963 (UCR_ENT 00069340) (BMNH); 2 q, , same collection data as preceding but 29 Oct. 1963 (UCR_ENT 00069365, UCR_ENT 00069366) (BMNH); 1 §ै, Nr. Tatuve, Kolosulu, 9.65916 S, $160.16361^{\circ}$ E, 19 May 1960, C.W. O’Brien leg. (UCR_ENT 00073534) (BPBM); 1 \%, same collection data as preceding (UCR_ENT 00073548) (BPBM); 1 on, Paripao, $9.56667^{\circ} \mathrm{S}, 160.33333^{\circ} \mathrm{E}, 21$ May

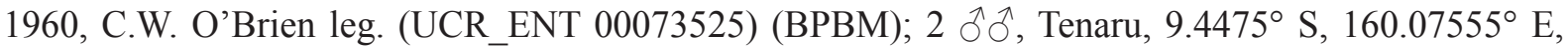
11 Aug. 1955, E.S. Brown leg. (UCR_ENT 00069346, UCR_ENT 00069347) (BMNH); 3 우, same collection data as preceding (UCR_ENT 00069358-UCR_ENT 00069360) (BMNH); 1 $9,9.64555^{\circ} \mathrm{S}$,

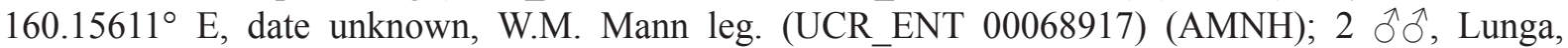
9.42971 ${ }^{\circ} \mathrm{S}, 160.04632^{\circ}$ E, 10 Feb. 1958, P.G. Fenemore leg. (UCR_ENT 00069352, UCR_ENT 00069353) (BMNH); 1 \%, same collection data as preceding (UCR_ENT 00069363) (BMNH); 1 , same collection data as preceding but 29 Jul. 1955, E.S. Brown leg. (UCR_ENT 00069364) (BMNH); $1 \delta^{\lambda}$, Guadalcanal, $9.6 \mathrm{~km}$ SE of Honiara, Lunga, 9.49471 ${ }^{\circ} \mathrm{S}, 160.01181^{\circ} \mathrm{E}, 2$ Jun. 1960, C.W. O’Brien leg. (UCR_ENT 00073527) (BPBM). - Malaita Province: 1 o, Alite Island, $12 \mathrm{~km} \mathrm{NE}$ of Dala, $8.6325^{\circ} \mathrm{S}, 160.69638^{\circ} \mathrm{E}, 300 \mathrm{~m}, 12$ Jun. 1964, J. Sedlacek leg. (UCR_ENT 00073555) (BPBM); 1 q, Alite Island, Dala, $8.59027^{\circ} \mathrm{S}, 160.68555^{\circ} \mathrm{E}, 50 \mathrm{~m}, 9-14$ Jun. 1964, J. and M. Sedlacek leg. (UCR ENT 00073551) (BPBM); 1 q, Alite Island, Tangtalau-Kwalo, $8.73333^{\circ} \mathrm{S}, 160.73333^{\circ} \mathrm{E}, 200 \mathrm{~m}$, 30 Sep. 1957, J.L. Gressittleg.(UCR_ENT 00073554)(BPBM). - SantaY Ysabel: $1{ }^{\jmath}$ ô, Sukapisu, $8.11444^{\circ}$ S, $159.33638^{\circ}$ E, 900 m, 19 Jun. 1960, C.W. O’Brien leg. (UCR_ENT 00073533) (BPBM); 1 q, same collection data as preceding but 18 Jun. 1960 (UCR_ENT 00073558) (BPBM). - Western Province: 1 , Kolombangara, Pepele, $8.05^{\circ}$ S, $156.96667^{\circ}$ E, 30 m, 12 Feb. 1964, P. Shanahan leg. (UCR_ENT 00073556) (BPBM); 1 $\hat{\text {, }}$, same collection data as preceding but 9 Feb. 1964 (UCR_ENT 00073528) (BPBM); 1 `, Gizo Island, Gizo, 8.1 ${ }^{\circ} \mathrm{S}, 156.85^{\circ} \mathrm{E}, 100 \mathrm{~m}$, Dec. 1976, N.L.H. Krauss leg. (UCR_ENT 00073529) (BPBM); 1 + , same collection data as preceding (UCR_ENT 00073547) (BPBM); 1 ڤ̂, same collection data as preceding but Feb. 1984 (UCR_ENT 00073526) (BPBM); 1 ô, New Georgia Islands Co., Banga, $8.28384^{\circ} \mathrm{S}, 157.21628^{\circ}$ E, 12 Oct. 1964, E.S. Brown leg. (UCR_ENT 00069350) (BMNH); 1 q, Vella Lavella Island, Ulo Crater, 7.68555 $\mathrm{S}, 156.58472^{\circ} \mathrm{E}, 10 \mathrm{~m}, 21$ Jul. 1963, P. Shanahan leg. (UCR_ENT 00073552) (BPBM); 1 क , Lunga River, 8.08638 ${ }^{\circ}$ S, $156.78083^{\circ}$ E, 6 Nov. 1944, H.E. Milliron leg. (UCR_ENT 00073549) (BPBM).

\section{Redescription}

Male

Body Length. Medium, total length $8.58 \mathrm{~mm}, \mathrm{SD} \pm 0.16$ (Appendix). 
Coloration (Figs 14, 17). Yellowish-brown and dark brown. Head anteriorly straw-colored, posteriorly brown. Antenna straw colored or light brown. First and second segments of labium light brown, third segment brown. Pronotum of thorax dark brown with straw-colored humeral tubercle, posterior margin and parascutellar lobe, scutellum dark brown basally, straw-colored apically including scutellar apex, pleuron dark brown with straw-colored suffusion, sternum dark brown. Corium of hemelytron base strawcolored, apex dark brown, membrane dark brown. Femora of legs straw-colored with medial and apical darkening, tibiae basally straw-colored and apically brown, tarsi and claws brown. Abdomen dorsally yellowish-orange, ventrally straw-colored with dark brown patterns, anterior half of connexivum dark brown, posterior half straw-colored, exposed part of pygophore dark brown.

VestiTURE. Densely setose. Head with some curved setae and short, fine, adpressed setae, ventral surface of postocular lobe with two rows of small, setigerous tubercles, with pair of long, straight setae on postocular lobe posterior to ocelli. Anterior lobe of thorax with irregular row of tuberculated, short, curved setae on lateral margins and fine, adpressed setae on dorsal surface, posterior lobe with short, sparse setae intermixed with short, tuberculated, curved setae. Corium of hemelytron with short, sparse, adpressed setae. Legs with two rows of spines and setigerous tubercles, tibia with regular rows of tuberculated, stout, sharp setae. Connexival margin of abdomen with a few clubbed setae on each segment or connexival margin with no prominent setae.

HEAD. Short conical; maxillary plate rounded apically; scape reaching apex of clypeus; eye hemispherical in dorsal view, less than $1 / 5$ length of head.

Thorax. Antero-lateral paired projections acute, diverging; surface of anterior lobe with low ridges; median pronotal depression not contiguous with transverse sulcus; paramedian carina weakly defined; anterior pronotal lobe equal in length to posterior lobe, equal in width to or slightly narrower than posterior lobe, higher than posterior lobe in lateral view; parascutellar lobe rounded, skewed towards median; scutellum semicircular, scutellar process long, apex rounded or spatulate.

HEMELYTRON. Reaching tip of abdomen.

LEGS. Same as genus description.

Aвdomen. Connexival margin smooth, not undulating, posterior margin not elevated.

GeNITALIA. Anterior margin of mediosternite 8 undulating, without medial apodeme; transverse bridge of pygophore extremely narrow, only consisting of margin of anterior opening of pygophore, margin of anterior opening angular, apodeme present, apical margin of posterior opening smooth; cup-like sclerite apically rounded, with adjacent paired round protuberances; arms of basal plate converging; ductifer with sclerotized, rounded ring; endosomal struts apically truncate, basally divided into two arms converging medially to form a tapered ridge basally; shape of dorsal phallothecal sclerite subacute with lateral broad, plate-like prolongations.

\section{Female}

Similar to males.

\section{Ecology}

This species has been collected most commonly on or inside Heliconia flowers (Heliconiaceae), but also on Pandanus (Pandanaceae) in forests, on foliage of Avocado pear (Lauraceae), in rotting tissue of the trunk of Roystonea regia (Arecaceae), on Nypa fruticans (Arecaceae), on Cocos nucifera (Arecaceae), under sacking bands on trees, logs near the coast, in coastal litter, under dead bark and on Musa (Musaceae). 


\section{Distribution}

This species is mostly found on New Britain Island and the Solomon Islands archipelago, but is also found on Fiji Island, Papua New Guinea, Sabah (Borneo) and Pulau Larat (Indonesia). This species has the eastern-most distribution of all physoderines with specimens found in Fiji.

\section{Remarks}

This species is placed in the Physoderes clade based on the phylogenetic analysis above. It is most closely related to $P$. curculionis, with which it shares the semicircular scutellum and the very narrow transverse bridge on the pygophore.

\section{Physoderes brevipennis sp. nov. urn:lsid:zoobank.org:act:7184D9A5-EFC9-4128-9578-91C7D9318AFF}

Figs 8, 14, 17, 19-20; Appendix

\section{Diagnosis}

This species is recognized among other species of Physoderes by the small size, the head and pronotum being densely covered with long, curved setae, the elongate conical head, the scape reaching the apex of the clypeus, the enlarged anterior pronotal lobe, the wide posterior pronotal lobe (males), the posterior pronotal lobe and parascutellar lobe being reduced in size, the brachypterous wing type and the ovoid abdomen. Among male genitalic features, the following are also diagnostic: the narrow transverse bridge of the pygophore, the endosomal struts being apically bulbous and basally divided into two plates converging to form a ridge medially, and the dorsal phallothecal sclerite shaped like a thin moustache. This species is distinct by being the only brachypterous Physoderes species and it is restricted to Guadalcanal of the Solomon Islands archipelago.

\section{Etymology}

The name brevipennis is chosen after the Latin adjective "brevipennis", meaning short-winged, to describe the short wings of this species.

\section{Material examined}

\section{Holotype}

SOLOMON ISLANDS: ${ }^{\lambda}$, Guadalcanal, Mt Austen, $9.55472^{\circ}$ S, $160.10666^{\circ}$ E, 305 m, 11 Feb. 1965, P. Greenslade leg. (UCR_ENT 00069375) (BMNH).

\section{Paratypes}

SOLOMON ISLANDS: 1 $\widehat{\jmath}$, same collection data as for holotype but 20 Apr.-3 May 1965, P. Greenslade leg. (UCR_ENT 00069376) (BMNH); 1 §, same collection data as preceding but 3 Jul.-24 Aug. 1965 (UCR_ENT 00069372) (BMNH); 1 o, same collection data as preceding but 10 May-23 Jun. 1965 (UCR_ENT 00069371) (BMNH); 1 §o, Guadalcanal, Mt Austen, $9.61777^{\circ} \mathrm{S}, 160.12138^{\circ}$ E, Dec. $1965-$ Jan. 1966, P. Greenslade leg. (UCR_ENT 00069370) (BMNH).

\section{Other material}

SOLOMON ISLANDS: Guadalcanal: 1 \&, Gallego Camp 2, 9.5772 ${ }^{\circ} \mathrm{S}, 160.14555^{\circ} \mathrm{E}, 10 \mathrm{Jul}$. 1965, collector unknown (UCR_ENT 00069382) (BMNH); 1 9. Mt Austen, 9.55472 ${ }^{\circ} \mathrm{S}, 160.10666^{\circ} \mathrm{E}, 305$ m, 3 Jul.-24 Aug. 1965, P. Greenslade leg. (UCR ENT 00069378) (BMNH); 1 ${ }^{\lambda}$, same collection data as preceding but $10 \mathrm{Jan} .1966$ (UCR ENT 00069373) (BMNH); 1 , same collection data as preceding but 26 Jun 1965 (UCR ENT 00069381) (BMNH); 1 ô, same collection data as preceding but 20 Mar.-5 Apr. 1965 (UCR ENT 00069374) (BMNH); 1 o, same collection data as preceding but 12 Oct. 1965 (UCR_ENT 00069379) (BMNH); 2 우, Mt Austen, 9.61777 S, 160.12138 E, Dec. 1965-Jan. 1966, 
P. Greenslade leg. (UCR_ENT 00069377, UCR_ENT 00069380) (BMNH); 1 क, Mt Jonapau (Mt Chaunapaho), $9.63222^{\circ} \mathrm{S}, 160.11638^{\circ} \mathrm{E}, 610 \mathrm{~m}, 5$ Jun. 1965, P. Greenslade leg. (UCR_ENT 00069383) $(\mathrm{BMNH})$.

\section{Description}

\section{Male}

Body LENGTH. Small, total length $6.61 \mathrm{~mm}, \mathrm{SD} \pm 0.35$ (Appendix).

Coloration (Figs 14, 17). Brown. Connexivum of abdomen brown with posterior margin straw-colored.

Vestiture. Densely setose. Head with widespread curved setae, ventral surface of postocular lobe with sparse, setigerous tubercles, with pair of long, straight setae on postocular lobe posterior to ocelli. Anterior lobe of thorax with tuberculated, short, curved setae on lateral margins and along dorsal ridges, posterior lobe with short, curved setae on humeral angle and sparsely distributed along dorsal surface. Corium of hemelytron with short, curved setae. Legs with two rows of spines and setigerous tubercles, tibia with regular rows of tuberculated, stout, sharp setae. Connexival margin of abdomen with a few clubbed setae on each segment.

HEAD. Elongate conical; maxillary plate rounded apically; scape just surpassing apex of clypeus; eye hemispherical in dorsal view, less than $1 / 5$ length of head.

Thorax. Antero-lateral paired projections acute, diverging; surface of anterior lobe with low ridges; median pronotal depression not contiguous with transverse sulcus; paramedian carina strongly defined; anterior pronotal lobe longer and wider than posterior lobe, higher than posterior lobe in lateral view; parascutellar lobe bell-shaped, skewed towards median; scutellum rounded triangular, scutellar process short, apex subacute.

Hemelytron. Not reaching tip of abdomen.

LeGs. Same as genus description.

ABDomen. Ovoid, with rounded terminal margin; connexival margin undulating, posterior margin not elevated.

Genitalia. Anterior margin of mediosternite 8 undulating, without medial apodeme; transverse bridge of pygophore narrow, margin of anterior opening angular, apodeme present, apical margin of posterior opening smooth; cup-like sclerite apically rounded, with adjacent paired round protuberances; arms of basal plate rounded; ductifer with sclerotized rounded ring; endosomal struts apically bulbous, basally divided into two plates converging to form a ridge medially; shape of dorsal phallothecal sclerite shaped like a thin moustache.

\section{Female}

Similar to males, with abdomen wider (average width $3.80 \mathrm{~mm}$ ).

\section{Ecology}

This species has most often been collected using pitfall and carrion traps and one specimen was found on rotting pawpaw (Caricaceae).

\section{Distribution}

This species is restricted to Guadalcanal of the Solomon Islands archipelago. 


\section{Remarks}

This species is placed in the Physoderes clade based on the phylogenetic analysis above. No other brachypterous physoderine species is found in the Oriental and Australasian region. The brachypterous males retain the enlarged anterior pronotum, but have a reduced posterior pronotal lobe.

Physoderes curculionis China, 1935

Figs 8, 14, 16-17, 19-20; Appendix

Physoderes curculionis China, 1935: 497.

Physoderes insulanus Miller, 1940: 543, fig. 88. New synonymy.

Physoderes patagiata Miller, 1941: 782, fig. 7. New synonymy.

Physoderes minor Usinger, 1946: 50, fig. 11. New synonymy.

Physoderes kalshoveni Miller, 1954: 86, fig. 10. New synonymy.

\section{Diagnosis}

This species is recognized among species of Physoderes by its small size (7.64 mm average length), the short and conical head, the scape reaching the apex of the clypeus, the anterior pronotal lobe being equal to or slightly narrower than the posterior lobe, the posterior pronotal lobe being rugose, the rounded parascutellar lobe, which is skewed towards the median, the semicircular scutellum, the spatulate and apically rounded scutellar process, the hemelytron not reaching the tip of the abdomen, the anterior margin of mediosternite 8 undulating and with an apodeme, the extremely narrow transverse bridge of the pygophore, and the endosomal struts being apically subacute and basally divided into two plates converging medially to form a ridge. This species is most similar to $P$. azrael, but can be differentiated by the elevation of the pronotum, the shorter and more ovoid abdomen, and the shape of the endosomal struts.

\section{Material examined}

\section{Holotype}

MALAYSIA: ${ }^{\top}$, Malaya, unknown locality, $3.11^{\circ} \mathrm{N}, 101.72111^{\circ} \mathrm{E}$, no date provided, (UCR_ENT 00018529) (BMNH).

\section{Paratype}

MALAYSIA: 1 q, Selangor, Petaling Co., Serdang, $3.02277^{\circ}$ N, $101.71361^{\circ}$ E, 14 Jan. 1935, G.H. Corbett leg. (UCR_ENT 00018525) (BMNH).

\section{Other material}

CHRISTMAS ISLAND: 1 , $10.45917^{\circ} \mathrm{S}, 105.68972^{\circ} \mathrm{E}, 248 \mathrm{~m}, 28$ Jan. 1933, unknown collector, holotype of Physoderes insulanus (junior synonym) (UCR_ENT 00018532) (BMNH).

GUAM: 1 O, 3 mi. S of Piti, $13.45444^{\circ}$ N, $144.70444^{\circ}$ E, 98 m, 23 May 1936, O.H. Swezey leg., paratype of Physoderes minor (junior synonym) (UCR_ENT 00073581) (BPBM); 1 , , same collection data as preceding (UCR_ENT 00073592) (BPBM); 1 $\overline{+}$, Mariana Is., Mt Lamlam Co., Mt Lalam, $13.33583^{\circ} \mathrm{N}$, $144.66527^{\circ} \mathrm{E}, 406 \mathrm{~m}$, Dec. 1958, N.L.H. Krauss leg. (UCR_ENT 00073596) (BPBM); 1 ㅇ, $1 \mathrm{mi} . \mathrm{SE}$ of Asan, $13.47305^{\circ} \mathrm{N}, 144.71305^{\circ}$ E, 244 m, 31 Oct. 1947, H.S. Dybas leg. (UCR_ENT 00031420)

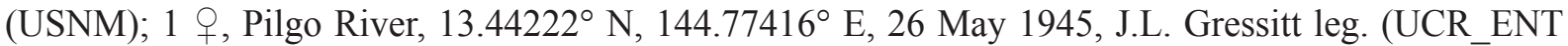
00031421) (USNM); 1 9, same collection data as preceding but G.E. Bohart and J.L. Gressit leg. (UCR

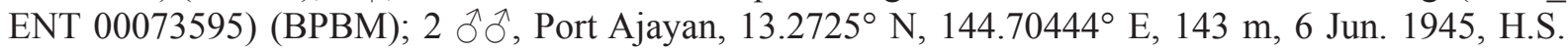
Dybas leg. (UCR_ENT 00073588, UCR_ENT 00073589) (BPBM); 1 \&, $2 \mathrm{mi}$. W of Piti, $13.45472^{\circ} \mathrm{N}$, $144.695^{\circ}$ E, $61 \mathrm{~m}$, on Glycine sp. (Fabaceae), 20 Jul. 1937, R.G. Oakley leg. (UCR_ENT 00031419) (USNM); 3 웅, Dededo, $13.52^{\circ} \mathrm{N}, 144.84^{\circ} \mathrm{E}, 19$ May 1936, R.L. Usinger leg., paratypes of Physoderes 
minor (junior synonym) (UCR_ENT 00046627-UCR_ENT 00046629) (CAS); 1 ㅇ, Dededo, $13.52^{\circ} \mathrm{N}$, $144.4^{\circ}$ E, 13 Jul. 1937, R.G. Oakley leg. (UCR_ENT 00031416) (USNM); 1 ô, same collection data as preceding but 23 Feb. 1938 (UCR_ENT 00031412) (USNM); 2 우, same collection data as preceding but 25 Aug. 1937 (UCR_ENT 00031417, UCR_ENT 00031418) (USNM); 2 우, Harmon Field, $13.50722^{\circ} \mathrm{N}, 144.81527^{\circ} \mathrm{E}, 54 \mathrm{~m}$, on Carica papaya L. (Caricaceae), 21 Jan. 1949, collector unknown (UCR_ENT 00031422, UCR_ENT 00031423) (USNM); 1 ○े, Mt Alifan, $13.38055^{\circ} \mathrm{N}, 144.67138^{\circ} \mathrm{E}$, Jun. 1936, R.L. Usinger leg., paratype of Physoderes minor (junior synonym) (UCR_ENT 00073579) (BPBM); 1 +, same collection data as preceding but 26 May 1936, paratype of Physoderes minor (junior synonym) (UCR_ENT 00068911) (AMNH); 1 , same collection data as preceding, paratype of Physoderes minor (junior synonym) (UCR_ENT 00046625) (CAS); 1 ㅇ, Mt Santa Rosa, $13.50805^{\circ} \mathrm{N}$, $144.91083^{\circ}$ E, 182 m, 16 May 1948, G.E. Bohart and J.L. Gressit leg. (UCR_ENT 00031425) (USNM); $1 \delta^{\top}$, Piti, $13.46^{\circ} \mathrm{N}, 144.69166^{\circ} \mathrm{E}, 5 \mathrm{~m}, 26$ May 1936, O.H. Swezey leg., paratype of Physoderes minor (junior synonym) (UCR_ENT 00073577) (BPBM); 1 q, same collection data as preceding but 27 Oct. 1936, paratype of Physoderes minor (junior synonym) (UCR_ENT 00073593) (BPBM); same collection

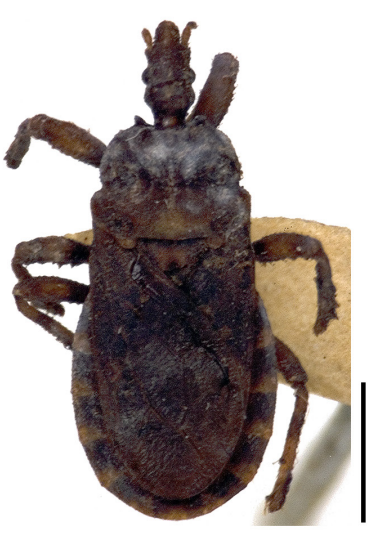

P. insulanus Holotype of Junior Synonym UCR_ENT 00018532

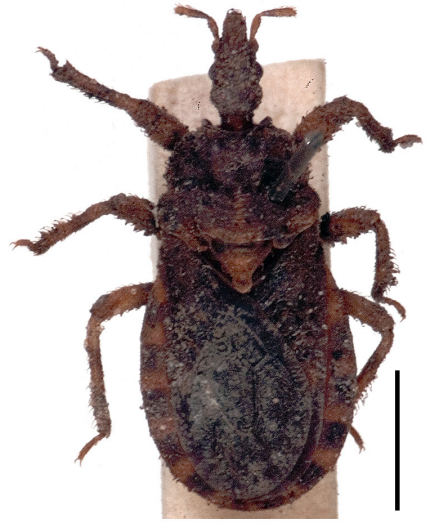

P. patagiata Holotype of Junior Synonym UCR_ENT 00018518

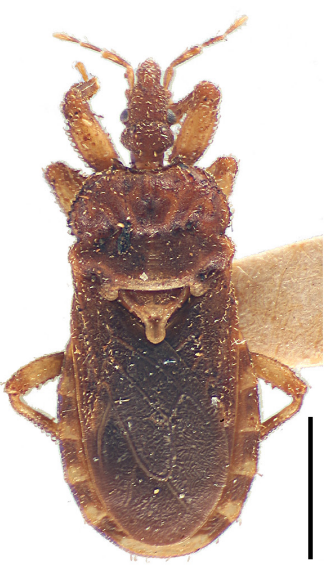

P. minor

Paratype of Junior Synonym UCR_ENT 00073577

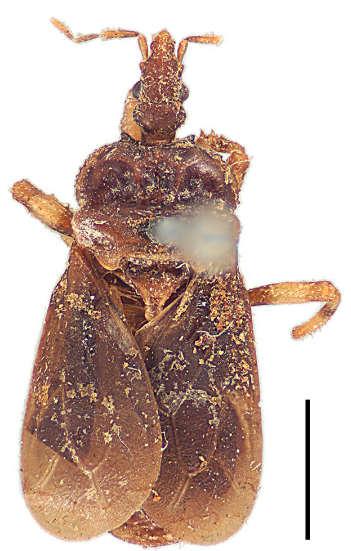

P. kalshoveni

Holotype of Junior Synonym UCR_ENT 00023947

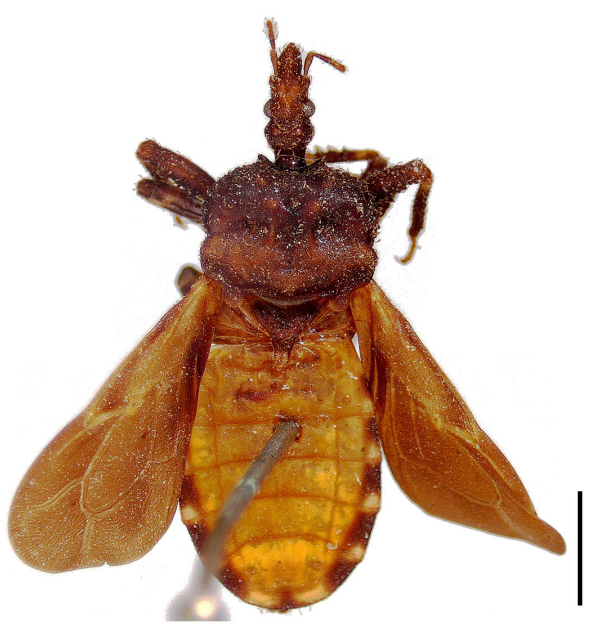

P. buruensis

Holotype of Junior Synonym ZMA.INS.787862
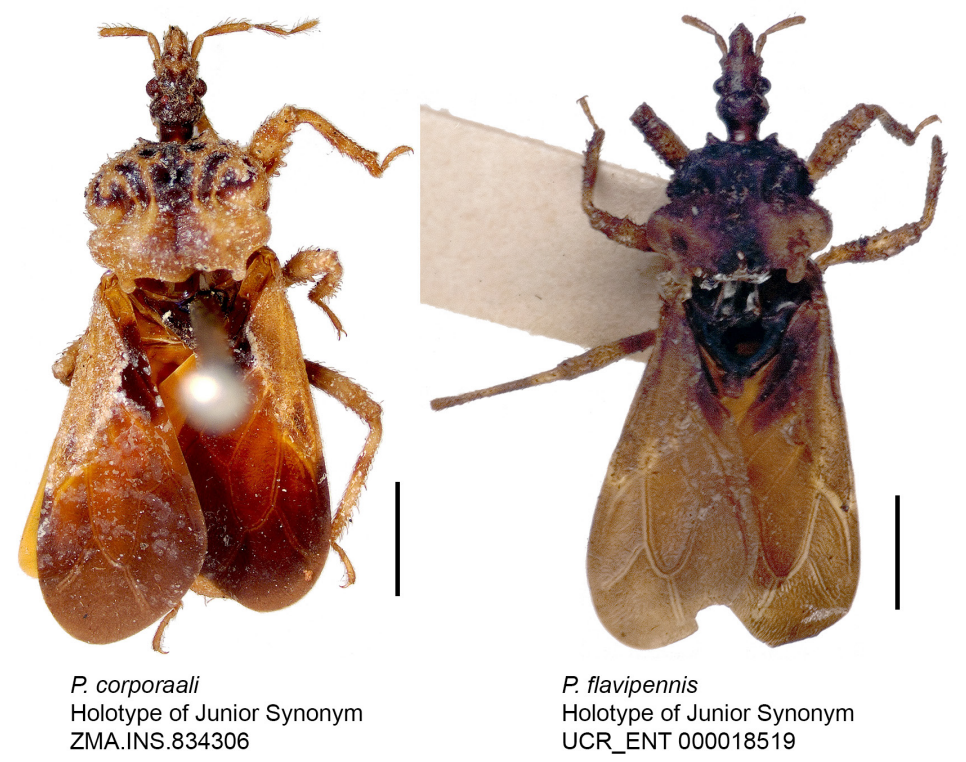

Fig. 16. Dorsal habitus images for junior synonym holotypes of species in Physoderes Westwood, 1845 (except $P$. minor $=$ paratype). Scale bars $=2 \mathrm{~mm}$. 
data as preceding, paratype of Physoderes minor (junior synonym) (UCR_ENT 00046626) (CAS); 1 juv., Piti, $13.46^{\circ}$ N, $144.69166^{\circ}$ E, 5 m, 22 May 1936, O.H. Swezey leg. (UCR_ENT 00046624) (CAS); 1 옹 Pt Oca, $13.503^{\circ} \mathrm{N}, 144.771^{\circ} \mathrm{E}$, May 1945, G.E. Bohart and J.L. Gressit leg. (UCR_ENT 00073590) (BPBM); 1 ô, same collection data as preceding but 19 May 1945 (UCR_ENT 00073587) (BPBM); 1 ㅇ, same collection data as preceding but 15 May 1945 (UCR_ENT 00073594) (BPBM); 1 , Santa Rita, $13.37416^{\circ}$ N, $144.70805^{\circ}$ E, 69 m, 25 Jan. 1948, collector unknown (UCR_ENT 00031424) (USNM); $1 \overbrace{}^{\lambda}$, unknown locality, $13.44416^{\circ} \mathrm{N}, 144.79361^{\circ} \mathrm{E}, 37 \mathrm{~m}$, no date provided, D.T. Fullaway leg. (UCR_ENT 00031413) (USNM); 2 우, Guam, 1937, R.G. Oakley leg. (UCR_ENT 00031414,

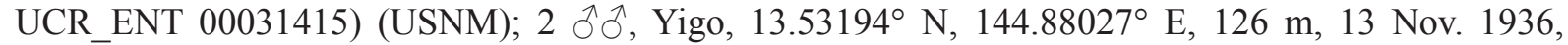
O.H. Swezey leg., paratypes of Physoderes minor (junior synonym) (UCR_ENT 00073578, UCR_ENT 00073580) (BPBM).

INDONESIA: Java: $1{ }^{\top}$, Ambarawa, $7.25611^{\circ} \mathrm{S}, 110.40638^{\circ} \mathrm{E}$, no date provided, collector unknown (UCR_ENT 00024014) (RMNH); 1 ○, Buitenzorg (Bogor), 6.58916 ${ }^{\circ} \mathrm{S}, 106.79305^{\circ} \mathrm{E}, 250 \mathrm{~m}$, Jan. 1926, L.G.E. Kalshoven leg., holotype of Physoderes kalshoveni (junior synonym) (UCR_ENT 00023947) (RMNH); 1 o , Bogor, $6.58916^{\circ} \mathrm{S}, 106.79305^{\circ} \mathrm{E}, 240 \mathrm{~m}, 28$ Apr. 1954, A.H.G. Alston leg. (UCR_ENT

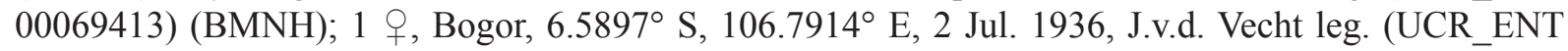

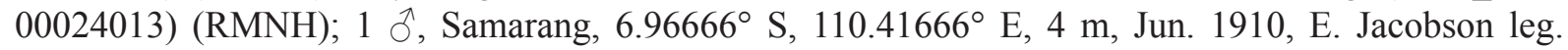
(UCR_ENT 00024012) (RMNH). - Maluku: 1 \%, Ambon County, Waai, Ambon Island, $3.565^{\circ} \mathrm{S}$, $128.32083^{\circ}$ E, 93 m, 10 Mar. 1965, A.M.R. Wegner leg. (UCR_ENT 00073586) (BPBM). - Larat: 1 q, $7.78777^{\circ}$ S, $131.81694^{\circ}$ E, Dec. 1907, F. Muir leg. (UCR_ENT 00046621) (CAS). - Sumatra: 1 subadult, Sumatera Barat (West Sumatra), $0.74^{\circ} \mathrm{N}, 100.8^{\circ} \mathrm{E}$, no date provided, Muller leg. (UCR ENT 00024032) (RMNH).

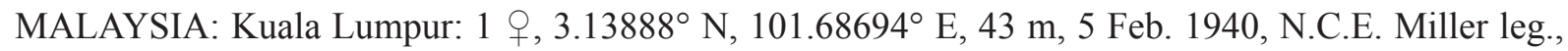
paratype of $P$. patagiata (junior synonym) (UCR_ENT 00069396) (BMNH). - Penang: 6 ô $\partial$, Penang Island, $5.37027^{\circ} \mathrm{N}, 100.2375^{\circ} \mathrm{E}, 198 \mathrm{~m}$, no date provided, Baker leg. (UCR_ENT 00031397-UCR_ENT 00031402); 8 우옹 same collection data as preceding (UCR_ENT 00031403-UCR_ENT 00031410) (USNM). - Sarawak: 1 \% , Kuching, $1.53111^{\circ} \mathrm{N}, 110.3441 \overline{6}^{\circ} \mathrm{E}, 12 \mathrm{~m}$, no date provided, collector unknown (UCR_ENT 00069397) (BMNH).

NORTHERN MARIANA ISLANDS: $1{ }^{\AA}$, Saipan, Pagan Island, $18.13555^{\circ} \mathrm{N}, 145.79111^{\circ} \mathrm{E}, 155 \mathrm{~m}$, 22 Aug. 1954, G. Corwin leg. (UCR_ENT 00073582) (BPBM); 1 \%, same collection data as preceding (UCR_ENT 00073591) (BPBM); 1 subadult, same collection data as preceding (UCR_ENT 00073597) (BPBM); 1 juv., same collection data as preceding (UCR_ENT 00073598) (BPBM).

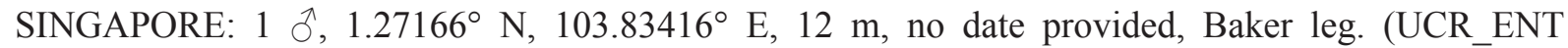
00031411) (USNM).

\section{Redescription}

Male

Body LENGTH. Small, total length $7.64 \mathrm{~mm}, \mathrm{SD} \pm 0.21$ (Appendix).

Coloration (Figs 14, 16-17). Brown. Head brown. Scape, pedicel and basiflagellomere of antenna light brown, distiflagellomere basally light brown, straw-colored apically. First segment of labium light brown, second segment straw-colored, third segment brown. Pronotum of thorax anterior lobe light brown to dark brown with straw-colored ridges, posterior lobe light brown to brown, with straw-colored posterior margin including parascutellar lobe, scutellum basally brown, apically straw-colored including scutellar process, pleuron brown to dark brown, sternum brown to dark brown. Corium of hemelytron light brown to brown, membrane dark brown. Fore femora of legs straw-colored, sub-basally and apically 
with brown annulations, tibiae straw colored, medially and apically with brown annulations, tarsi and claws straw-colored to brown. Abdomen dorsally yellowish-orange, ventrally straw-colored with brown and dark brown patterns, anterior half of connexivum dark brown, posterior half straw-colored, exposed part of pygophore brown or dark brown.

Vestiture. Sparsely setose. Head with some curved setae and short, fine, adpressed setae, ventral surface of postocular lobe with sparse, setigerous tubercles, with pair of long, straight setae on postocular lobe posterior to ocelli. Anterior lobe of thorax with tuberculated, short, curved setae on lateral margins and along dorsal ridges, posterior lobe with short, curved setae on humeral angle and sparsely distributed along dorsal surface. Corium of hemelytron with short, curved setae. Legs with two rows of spines and setigerous tubercles, tibia with regular rows of tuberculated, stout, sharp setae. Connexival margin of abdomen with a few clubbed setae on each segment, or connexival margin with no prominent setae.

HEAD. Short conical; maxillary plate rounded apically; scape reaching apex of clypeus; eye hemispherical in dorsal view, less than $1 / 5$ length of head.

Thorax. Antero-lateral paired projections acute, diverging; surface of anterior lobe with low ridges; median pronotal depression not contiguous with transverse sulcus; paramedian carina weakly defined; anterior pronotal lobe longer than posterior lobe, equal width to or slightly narrower than posterior lobe, higher than posterior lobe in lateral view; parascutellar lobe rounded, skewed towards median; scutellum semicircular, scutellar process long, apex rounded or spatulate.

HemelYtron. Not reaching tip of abdomen.

Legs. Same as genus description.

ABDomen. Ovoid, with rounded terminal margin; connexival margin slightly undulating, posterior margin not elevated.

Genitalia. Anterior margin of mediosternite 8 undulating, with medial apodeme; transverse bridge of pygophore extremely narrow, only consisting of margin of anterior opening of pygophore, margin of anterior opening rounded, apodeme absent, apical margin of posterior opening smooth; cup-like sclerite apically rounded with adjacent paired round protuberances; arms of basal plate rounded; ductifer with sclerotized rounded ring; endosomal struts apically subacute, basally divided into two plates converging medially to form a ridge; shape of dorsal phallothecal sclerite subacute, with short, apical lobes and rounded lateral plates at apex.

\section{Female}

Similar to male except slightly narrower anterior pronotal lobe width $(2.29 \mathrm{~mm}$ average $)$ than posterior lobe width (2.64 $\mathrm{mm}$ average).

\section{Ecology}

This species has been recorded to feed on curculionid larvae and has been collected on decaying plant material including fallen banana (Musaceae) logs, rotten papaya (Caricaceae) plant, rotten pumpkin (Cucurbitaceae), on logs, on rotten boards on the ground and beneath rotten breadfruit (Moraceae).

\section{Distribution}

This species has the most widespread distribution of all Oriental physoderines and can be found in peninsular Malaysia, Sumatra, Singapore, Java, Christmas Island, Ambon Island, Guam and Saipan. The presence of $P$. curculionis in Guam and Saipan is an odd distribution that questions whether this could be 
a secondary introduction, considering their association with banana, pumpkin and papaya plant material and curculionid larvae.

\section{Remarks}

This species is confirmed to belong to the Physoderes clade based on the phylogenetic analysis above. A number of names have been synonymized under $P$. curculionis based on examination of the type material. These are P. insulanus, P. kalshoveni, P. patagiata and P. minor. All share the diagnostic characters of $P$. curculionis listed above including those of the male genitalic morphology (for $P$. minor and $P$. kalshoveni), have no distinct features of their own, and are thus synonymized here.

\section{Physoderes esakii Cao et al., 2011}

Figs 13-14, 17

Physoderes esakii Cao, Tomokuni \& Cai, 2011: 23, figs 1-12.

Epirodera latithorax Esaki, 1931: 212 (nomen nudum).

Physoderes latithorax - Maldonado 1990: 380.

\section{Re-diagnosis}

This species is recognized among species of Physoderes by its short hemelytra, not reaching the abdominal apex, the slender scutellar spine, the round parascutellar lobe and the simple phallosoma without lateral prolongations as illustrated in the original description and color images provided by Cao et al. (2011). This species is most similar to P. fuliginosa but can be differentiated on these characters.

\section{Description}

Male

Refer to Cao et al. (2011) for full description.

\section{Distribution}

This species is only recorded from Botel Tobago (Orchid Island [Lanyu], Taiwan).

\section{Remarks}

A re-diagnosis is provided here, as the original diagnosis (under Remarks in Cao et al. 2011) refers to the sexually dimorphic enlargement of the anterior pronotal lobe also present in other species of Physoderes. Two female specimens likely to be conspecifics collected by J.F. Tsai on Botel Tobago island share the same short hemelytron not reaching the abdominal apex, but without an enlarged anterior pronotal lobe and with a rounder abdomen (J.F. Tsai and D. Rédei, pers. comm.; images examined here).

Physoderes fuliginosa (Stål, 1870)

Figs 8, 13-14, 17, 19; Appendix

Epirodera fuliginosa Stål, 1870: 693.

Physoderes fuliginosa - Maldonado 1990: 380.

\section{Diagnosis}

This species is recognized among species of Physoderes by the elongate head, the scape reaching the apex of the clypeus, the hemispherical eye that is not distinctly protruding, the acute and diverging anterolateral projection of the anterior pronotal lobe, the anterior pronotal lobe being wider than the posterior lobe, the rounded parascutellar lobe, the slender and straw-colored scutellar process, the pygophore 
HWANG W.S. \& WEIRAUCH C., Phylogeny and revision of Physoderes and allied genera

apical margin of the posterior opening having a short medial process and the phallosoma lacking flaplike prolongations. This species is most similar to $P$. minime sp. nov., but can be differentiated from it by the larger size, darker coloration, the hemelytron close to or attaining the tip of the abdomen, the presence of an apical median process on the posterior opening of the pygophore, and the lack of flap-like prolongations of the phallosoma.

\section{Material examined}

\section{Holotype}

PHILIPPINES: + , specimen image made available by T. Ishikawa, label information not examined here (NHRS).

\section{Other material}

INDONESIA: Borneo: $2 \widehat{\jmath}, 1.10611^{\circ} \mathrm{S}, 114.14388^{\circ} \mathrm{E}$, no date provided, Muller leg. (UCR_ENT

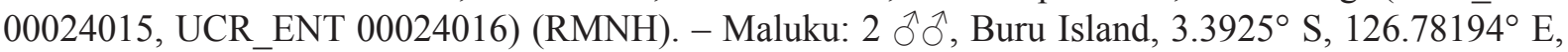
1903, collector unknown (UCR_ENT 00069252, UCR_ENT 00069253) (BMNH). - Sulawesi: 1 , Gorontalo, $0.5525^{\circ} \mathrm{N}, 123.06555^{\circ} \mathrm{E}$, no date provided, A. Forsten leg. (UCR_ENT 00024018) (RMNH). - Tidore Island: $1{ }^{\lambda}$, Kampung Guaepaji, $0.67333^{\circ} \mathrm{N}, 127.31166^{\circ} \mathrm{E}, 5-10 \mathrm{Jul}$. 1981, A.C. Messer leg. (UCR_ENT 00031353) (USNM).

PAPUA NEW GUINEA: 1 q, Manus Province, Manus Island, $2.09388^{\circ} \mathrm{S}, 146.87583^{\circ} \mathrm{E}$, no date provided, collector unknown (UCR_ENT 00069225) (BMNH).

PHILIPPINES: Basilan: 1 \%, Basilan Island, $6.69277^{\circ} \mathrm{N}, 122.02305^{\circ} \mathrm{E}$, no date provided, collector unknown (UCR_ENT 00069249) (BMNH). - Bukidnon: 29 우, Tangcolan, $7.97611^{\circ} \mathrm{N}, 125.02583^{\circ} \mathrm{E}$, no date provided, Baker leg. (UCR_ENT 00030985-UCR_ENT 00030999,UCR_ENT 00031313,UCR_

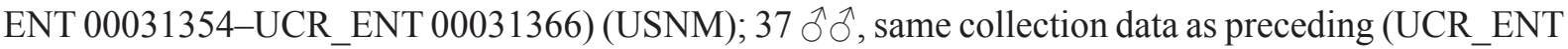
00031278-UCR_ENT 00031312, UCR_ENT 00031314, UCR_ENT 00031435) (USNM). - Leyte: $2{ }^{\top} \mathrm{o}^{\mathrm{N}}$, Biliran Island, $11.26722^{\circ} \mathrm{N}, 124.64833^{\circ} \mathrm{E}$, no date provided, Baker leg. (UCR_ENT 00031347 , UCR_ENT 00031348) (USNM); 1 ㅇ, $11.11388^{\circ} \mathrm{N}, 124.7375^{\circ}$ E, 5 Jan. 1915, G. Bottcher leg. (UCR ENT 00069223) (BMNH); 1 $\widehat{\text { }}$, same collection data as preceding but 3 May 1915 (UCR_ENT 00069247) (BMNH).-Luzon: $1{ }^{\top}$,Camarines Sur, MtIsarog,SLuzon, $13.65916^{\circ} \mathrm{N}, 123.37333^{\circ} \mathrm{E}, 1219 \mathrm{~m}, 13 \mathrm{Apr} .1916$, G. Bottcher leg. (UCR_ENT 00069243)(BMNH); 1 q, Laguna, Mt Makiling, $14.13^{\circ} \mathrm{N}, 121.2^{\circ} \mathrm{E}, 1$ May

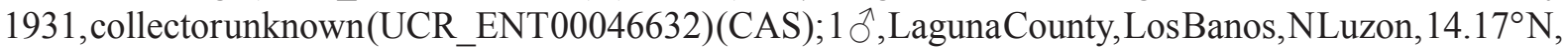
121.24416 E, 23 Dec. 1914, G. Bottcher leg. (UCR_ENT 00069234) (BMNH); 1 + , Mt Makiling, $14.13333^{\circ} \mathrm{N}, 121.2^{\circ}$ E, $244 \mathrm{~m}, 5$ May 1932, F.C. Hadden leg. (UCR_ENT 00046631) (CAS); 1 \%, Paete, Laguna, $14.3675^{\circ} \mathrm{N}, 121.52972^{\circ} \mathrm{E}$, no date provided, W. Schultze leg. (UCR_ENT 00069224)

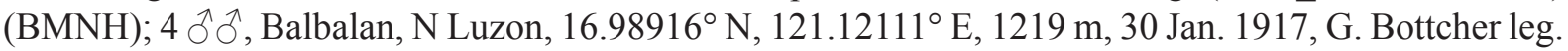
(UCR_ENT 00069200, UCR_ENT 00069201, UCR_ENT 00069238, UCR_ENT 00069239) (BMNH); $5 \widehat{\partial} \widehat{\jmath}$, same collection data as preceding but Mar. 1918 (UCR_ENT 00069202, UCR_ENT 00069203, UCR_ENT 00069235-UCR_ENT 00069237) (BMNH); 1 ô, same collection data as preceding but 2 Jul. 1917 (UCR_ENT 00069204) (BMNH); 2 $ぇ$, Imugan, N Luzon, $16.16166^{\circ} \mathrm{N}, 120.93888^{\circ} \mathrm{E}$, 1219 m, May 1917, G. Bottcher leg. (UCR_ENT 00069205, UCR_ENT 00069206) (BMNH); $1 \hat{\partial}$, same collection data as preceding but 30 Jun. 1917 (UCR_ENT 00069207) (BMNH); 1 o, same collection data as preceding but 25 Jun. 1917 (UCR_ENT 00069240) (BMNH); 1 + , Irisan, $16.42111^{\circ} \mathrm{N}$, $120.56888^{\circ} \mathrm{E}$, no date provided, Benguet and McGregor leg. (UCR_ENT 00031351) (USNM); $6 \partial^{\Uparrow} \widehat{\jmath}$, Mt Banahao, $14.0675^{\circ} \mathrm{N}, 121.4925^{\circ} \mathrm{E}$, no date provided, Baker leg. (UCR_ENT 00031341-UCR ENT 00031346) (USNM); 1 क , same collection data as preceding (UCR_ENT 00031386) (USNM); $1 \mathrm{O}^{\top}$, Mt Banahao, N Luzon, $14.0675^{\circ} \mathrm{N}, 121.4925^{\circ} \mathrm{E}, 610 \mathrm{~m}, 21 \mathrm{Jun} .1914, \overline{\mathrm{G}}$. Bottcher leg. (UCR_ENT 00069198) (BMNH); 1 Oे, same collection data as preceding but 29 Apr. 1914 (UCR_ENT 00069197) (BMNH); 1 ${ }^{\lambda}$, same collection data as preceding but 10 Jun. 1914 (UCR_ENT 00069199) (BMNH); 
$1 \hat{\jmath}$, same collection data as preceding but 17 Apr. 1914 (UCR_ENT 00069232) (BMNH); $1 \hat{\jmath}$, same collection data as preceding but 18 Aug. 1914 (UCR_ENT 00069195) (BMNH); 1 ô, same collection data as preceding but 23 Jun. 1914 (UCR_ENT 00069233) (BMNH); 1 Oे, same collection data as preceding but 1 May 1914 (UCR_ENT 00069196) (BMNH); 1 ○, Mt. Bulusan, S Luzon, $12.76916^{\circ} \mathrm{N}$, $124.05666^{\circ}$ E, 610 m, Sep. 1917, G. Bottcher leg. (UCR_ENT 00069242)(BMNH); 1 \&, Mt Maquiling, $14.12444^{\circ} \mathrm{N}, 121.22555^{\circ} \mathrm{E}, 18$ Jul. 1936, R.L. Usinger leg. (UCR_ENT 00046646) (CAS); 1 juv., Santo Tomas, $14.08694^{\circ} \mathrm{N}, 121.19444^{\circ} \mathrm{E}, 1924$, collector unknown (UCR_ENT 00031390) (USNM); 3 우오, Nueva Vizcaya, Imugin, $16.16138^{\circ} \mathrm{N}, 120.93972^{\circ} \mathrm{E}, 589 \mathrm{~m}$, no date provided, Baker leg. (UCR ENT 00031323, UCR_ENT 00031329, UCR_ENT 00031387); $6 \hat{\jmath} \widehat{\jmath}$, same collection data as preceding

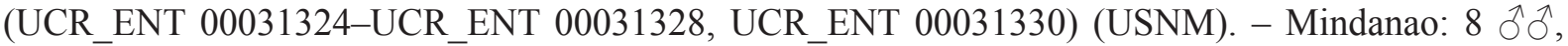
Butuan, $8.9475^{\circ} \mathrm{N}, 125.54055^{\circ} \mathrm{E}$, no date provided, Baker leg. (UCR_ENT 00031315-UCR_ENT 00031322); 6 우, same collection data as preceding (UCR_ENT 00031367-UCR_ENT 00031371,

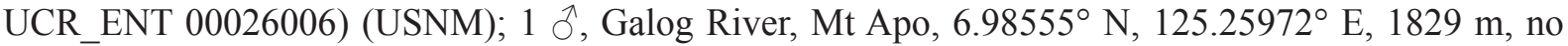
date provided, C.F. Clagg leg. (UCR_ENT 00068947) (AMNH); 1 ${ }^{\top}$, Iligan, $8.22805^{\circ} \mathrm{N}, 124.24527^{\circ} \mathrm{E}$, no date provided, collector unknown (UCR_ENT 00069241) (BMNH); $2 \lesssim \widehat{\jmath}$, no date provided, Baker leg. (UCR_ENT 00031349, UCR_ENT 00031350) (USNM); 1 ऽ, Mamungan, N Mindanao, $8.11722^{\circ} \mathrm{N}$, $124.21861^{\circ} \mathrm{E}, 1272 \mathrm{~m}, 18 \mathrm{Feb} .1915$, G. Bottcher leg. (UCR_ENT 00069227) (BMNH); $1 \overbrace{}^{\top}$, same collection data as preceding but 3 Mar. 1915 (UCR_ENT 00069228) (BMNH); 1 q, same collection data as preceding but 22 Feb. 1915 (UCR_ENT 00069216) (BMNH); 1 \% , same collection data as preceding but 19 Feb. 1915 (UCR_ENT 00069217) (BMNH); 1 \%, same collection data as preceding (UCR ENT 00069226) (BMNH); 1 §ै, Momungan, N Mindanao, 19 Feb. 1915, G. Bottcher leg. (UCR_ENT

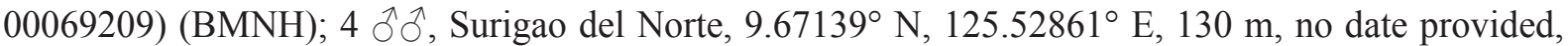
Baker leg. (UCR_ENT 00031331-UCR_ENT 00031334); 6 q 9 , same collection data as preceding (UCR ENT 00031335, UCR ENT 00031372-UCR ENT 00031376) (USNM); 1 ô, no date provided, Baker leg. (UCR_ENT 00031436) (USNM); 1 今, Surigao, N Mindanao, 9.67138 $\mathrm{N}, 125.52888^{\circ} \mathrm{E}$, 130 m, 20 Oct. 1915, G. Bottcher leg. (UCR_ENT 00069231) (BMNH); 1 ô, same collection data as

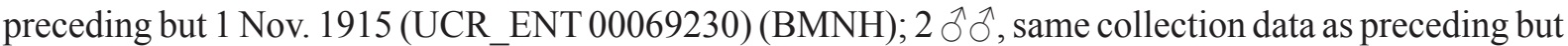
13 Nov. 1915 (UCR ENT 00069208,UCR ENT 00069229)(BMNH); 1 ð, Misamis Oriental, Hindangon, $20 \mathrm{~km} \mathrm{~S}$ of Gingoog, $7.81361^{\circ} \mathrm{N}, 124.96888^{\circ} \mathrm{E}, 600 \mathrm{~m}, 9-18$ Apr. 1960, H.M. Torrevillas leg. (UCR ENT 00073628) (BPBM); 1 , , no date provided, collector unknown (UCR ENT 00069222) (BMNH); 1 q, no date provided, collector unknown (UCR_ENT 00069220) (BMNH). - Sulu Province: 1 o, Siasi Island, Siasi, $5.53388^{\circ} \mathrm{N}, 120.86138^{\circ} \mathrm{E}, 300 \mathrm{~m}, 26$ Aug. 1958, H.E. Milliron leg. (UCR ENT 00073627) (BPBM). - Mindoro: $2 \delta^{\AA} \sigma^{\top}$, Abra de $\operatorname{Llog}, 13.45^{\circ} \mathrm{N}, 120.73333^{\circ} \mathrm{E}, 9 \mathrm{~m}$, no date provided, W. Schultze leg. (UCR_ENT 00069211, UCR_ENT 00069248) (BMNH); 1 \% , 13.12888 $\mathrm{N}, 121.06611^{\circ} \mathrm{E}, 112 \mathrm{~m}$, no date provided, S. Theodoro leg. (UCR ENT 00014053) (RMNH); 1 ${ }^{\lambda}$, Occidental Mindoro, San Jose, $12.35361^{\circ} \mathrm{N}, 121.06666^{\circ} \mathrm{E}, 30$ Jan. 1945 , E.S. Ross leg. (UCR ENT 00046630) (CAS). - Negros: 1 P, Negros Oriental, Mt Talinas (Mt Talinis), 9.24416 ${ }^{\circ} \mathrm{N}, 123.1775^{\circ} \mathrm{E}, 1020 \mathrm{~m}, 28$ Jun. 1958, H.E. Milliron leg. (UCR ENT 00073626) (BPBM). - Polillo: $1{ }^{\AA}$, Polillo Island, $14.77555^{\circ} \mathrm{N}, 121.92194^{\circ} \mathrm{E}$, $54 \mathrm{~m}$, no date provided, collector unknown (UCR_ENT 00024017) (RMNH); 2 $\widehat{\jmath}$, no date provided, W. Schultze leg. (UCR_ENT 00069212,UCR_ENT 00069213)(BMNH); 1 q, Polillo Island, $14.71805^{\circ} \mathrm{N}$, $121.94583^{\circ} \mathrm{E}, 27 \mathrm{~m}$, no date provided, collector unknown (UCR_ENT 00069219) (BMNH). - Romblon: $3 \mathrm{O}^{\mathrm{o}} \mathrm{O}$, Sibuyan Island, $12.4125^{\circ} \mathrm{N}, 122.55888^{\circ} \mathrm{E}, 1529 \mathrm{~m}$, no date provided, Baker leg. (UCR_ENT 00031338-UCR_ENT 00031340); 5 우옹 same collection data as preceding (UCR_ENT 00031381UCR_ENT 00031385)(USNM). - Samar: 5 ðð , Borongan, $11.60777^{\circ} \mathrm{N}, 125.43277^{\circ} \mathrm{E}, 19 \mathrm{~m}$, no date provided, W. Schultze leg. (UCR_ENT 00069214, UCR_ENT 00069215, UCR_ENT 00069244-UCR_ ENT 00069246) $(\mathrm{BMNH}) ; 2{ }^{\AA}{ }^{\circ}, 12.005^{\circ} \mathrm{N}, 124.77416^{\circ} \mathrm{E}, 37 \mathrm{~m}$, no date provided, Baker leg. (UCR ENT 00031336, UCR_ENT 00031337) (USNM); 4 q $q$, same collection data as preceding (UCR_ENT

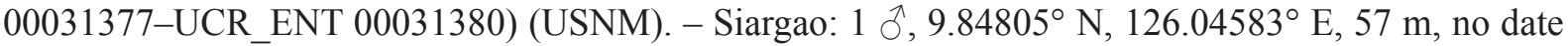
provided, collector unknown (UCR_ENT 00069251) (BMNH). - Panay: 1 + , NW Panay, $11.32083^{\circ} \mathrm{N}$, $122.53722^{\circ} \mathrm{E}, 180 \mathrm{~m}$, no date provided, Baker leg. (UCR_ENT 00031388) (USNM). $-1 \stackrel{\jmath}{\curvearrowright}$, Philippine 
Islands, $12.82027^{\circ} \mathrm{N}, 121.79694^{\circ} \mathrm{E}, 1912$, J.J. Mounsey leg. (UCR_ENT 00069210) (BMNH); 1 q, same collection data as preceding (UCR_ENT 00069218) (BMNH).

SOLOMON ISLANDS: 1 q, Guadalcanal, Guadalcanal Lavoro, $9.57722^{\circ} \mathrm{S}, 160.14555^{\circ} \mathrm{E}, 18 \mathrm{Feb}$. 1934, H.T. Pagden leg. (UCR_ENT 00046633) (CAS).

\section{Redescription}

Male

Body LenGth. Medium, total length $10.47 \mathrm{~mm}, \mathrm{SD} \pm 0.54$ (Appendix).

Coloration (Figs 14, 17). Dark brown. Head dark brown. Scape and pedicel of antenna light brown and brown, basiflagellomere brown, distiflagellomere basally brown, apically straw-colored. First segment of labium brown, second segment basally and apically brown, medially straw-colored, third segment brown. Pronotum of thorax dark brown with light brown markings, scutellum basally dark brown with scutellar process straw-colored, pleuron straw-colored with brown and dark brown patterns, sternum dark brown with brown suffusion. Corium of hemelytron brown to dark brown, membrane dark brown. Femur and tibia of legs straw-colored with medial and apical brown annulations, tarsus and claw light brown. Abdomen dorsally yellowish-orange, ventrally straw-colored with sub-lateral dark brown patterns, anterior half of connexivum dark brown, posterior half straw-colored, exposed part of pygophore brown.

Vestiture. Sparsely setose. Head with widespread curved setae, ventral surface of postocular lobe with sparse, setigerous tubercles, with pair of long, straight setae on postocular lobe posterior to ocelli. Anterior lobe of thorax with irregular row of tuberculated, short, curved setae on lateral margins and short, setigerous tubercles dispersed on dorsal surface, posterior lobe with short, curved setae on humeral angle and sparsely distributed along dorsal surface. Corium of hemelytron with short, curved setae. Legs with two rows of spines and setigerous tubercles, tibia with regular rows of tuberculated, stout, sharp setae. Connexival margin of abdomen with no prominent setae.

HEAD. Elongate conical; maxillary plate rounded apically; scape reaching apex of clypeus; eye hemispherical in dorsal view, less than $1 / 5$ length of head.

THorax. Antero-lateral paired projections acute, diverging; surface of anterior lobe with low ridges; median pronotal depression not contiguous with transverse sulcus; paramedian carina weakly defined; anterior pronotal lobe longer and wider than posterior lobe, higher than posterior lobe in lateral view; parascutellar lobe rounded; scutellum rounded triangular, scutellar process long, apex subacute.

HemeLytron. Reaching tip of abdomen.

LeGs. Same as genus description.

ABDomen. Connexival margin slightly undulating, posterior margin not elevated.

Genitalia. Anterior margin of mediosternite 8 undulating, without medial apodeme; transverse bridge of pygophore narrow, margin of anterior opening angular, apodeme present, apical margin of posterior opening with small medial process; cup-like sclerite apically rounded with sclerotized paired lateroventral slight protuberance; arms of basal plate converging; ductifer membranous; endosomal struts conical, with subacute apex, divided into two arms basally; dorsal phallothecal sclerite not sclerotized. 


\section{Female}

Similar to male, except with anterior pronotal lobe $(2.39 \mathrm{~mm}$ average $)$ distinctly narrower than posterior lobe (3.20 mm average) and with median pronotal depression contiguous with transverse sulcus.

\section{Ecology}

Nothing is known about the biology of this species.

\section{Distribution}

This species is widespread across the Philippines island archipelago and also recorded from Borneo, parts of the Indonesian archipelago, Papua New Guinea and the Solomon Islands.

\section{Remarks}

The holotype of $P$. fuliginosa is a female with a narrow anterior pronotal lobe and unknown locality, which makes it difficult to associate it with a male. Multiple male specimens found on Mindanao with

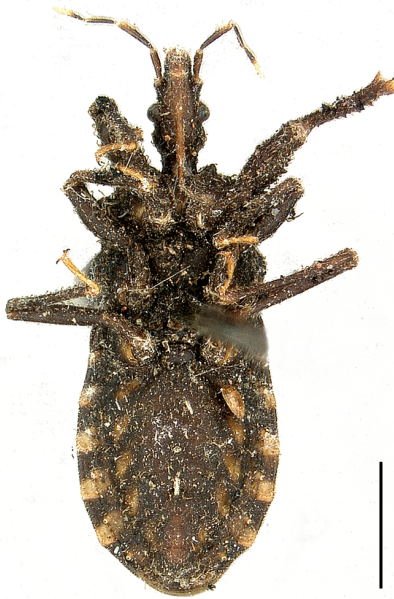

$P$. anamalaiensis sp. nov. UCR_ENT 00046639

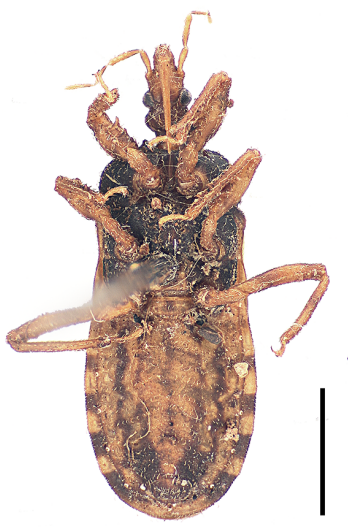

P. azrael UCR_ENT 00073529

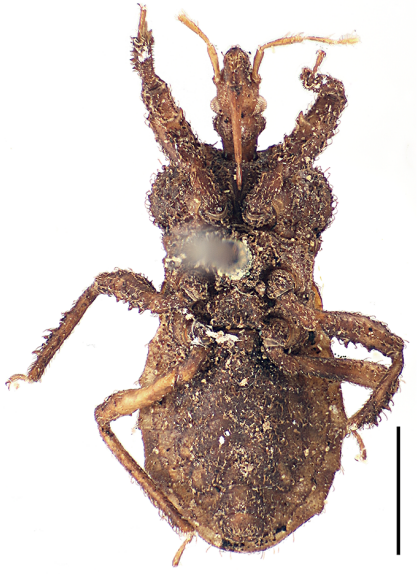

$P$. brevipennis sp. nov. Paratype UCR_ENT 00069376

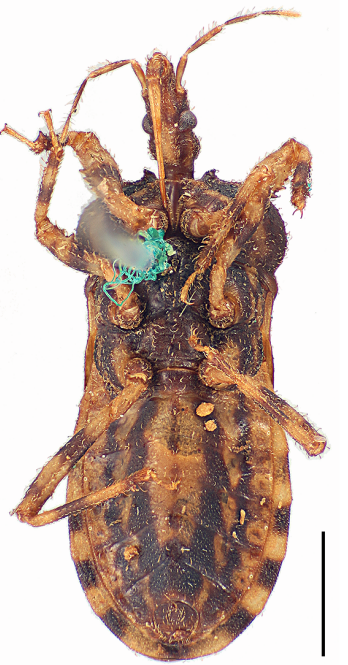

P. fuliginosa UCR_ENT 00030978

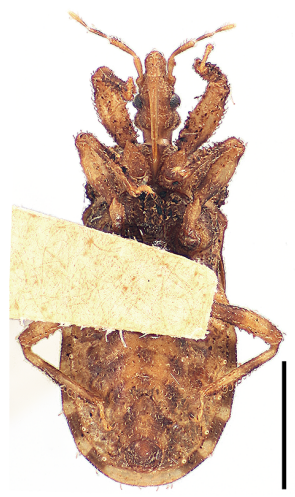

P. curculionis UCR_ENT 00073577

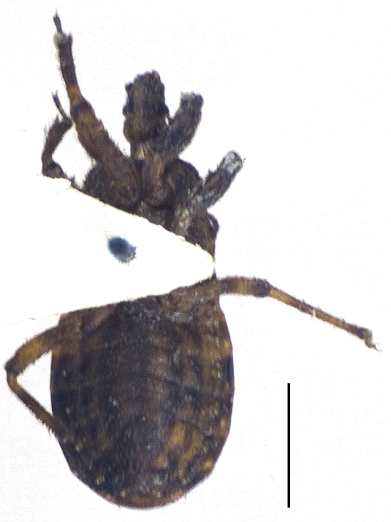

$P$. curculionis Paratype UCR_ENT 00018525

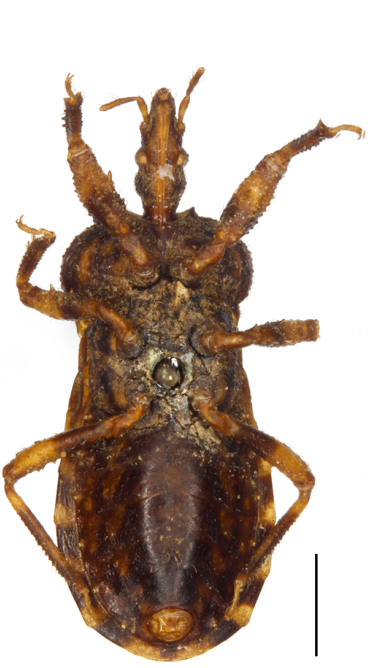

P. esakii

Holotype Imaged by L. Cao

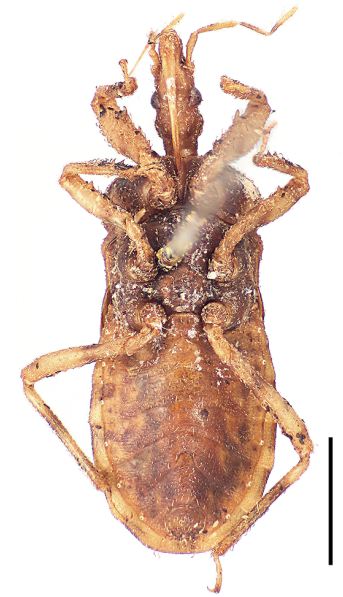

P. minime sp. nov. Holotype UCR_ENT 00030979

Fig. 17. Ventral habitus images for species of Physoderes Westwood, 1845 (partial). Scale bars $=2 \mathrm{~mm}$. 
corresponding females that match the holotype morphology confirm that the holotype is most likely from the Philippines region and the redescription here is based on the males from Mindanao. The description of $P$. fuliginosa is difficult, as specimens from the Philippines show variation in overall size and coloration, but do not differ morphologically. Dissections of male genitalia from different geographic localities also do not show any variation. Hence, P. fuliginosa is here considered to be highly variable in size and general coloration.

\section{Physoderes minime sp. nov. urn:Isid:zoobank.org:act:6B773A65-2FB4-4063-8EE6-7CEFA2ADDB5A}

Figs 8, 14, 17, 19-20; Appendix

\section{Diagnosis}

This species is recognized among species of Physoderes by the elongate head, which is as long as the pronotum, the scape not reaching the apex of the clypeus, the hemispherical eye being slightly flattened, the antero-lateral projection of the anterior pronotal lobe subacute and diverging, the anterior pronotal lobe being wider than the posterior lobe, the rounded parascutellar lobe, the scutellar process being slender and straw-colored and the short hemelytron which does not reach the tip of the abdomen. This species is most similar to $P$. fuliginosa, but can be differentiated from it by the smaller size, yellowish coloration, the short hemelytron and by having a smooth apical margin on the posterior opening of the pygophore, as well as a small apical dorsal phallothecal sclerite.

\section{Etymology}

The name minime is a noun in apposition, after the fictional movie character Mini-Me from the Austin Powers movie series. The name given is to describe the miniaturized resemblance of this species to the co-occurring larger P. fuliginosa.

\section{Material examined}

\section{Holotype}

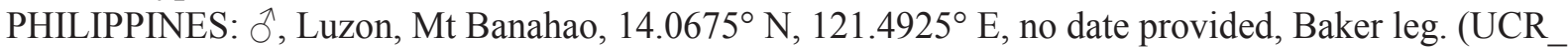
ENT 00030979) (USNM).

\section{Paratypes}

PHILIPPINES: Panay: 1 ô, Capiz, Capiz Jamindan, $11.44055^{\circ} \mathrm{N}, 122.5925^{\circ} \mathrm{E}$, no date provided,

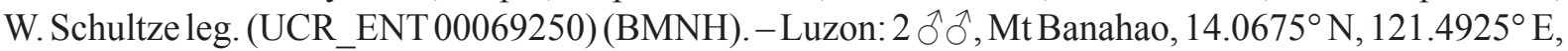
no date provided, Baker leg. (UCR_ENT 00031432, UCR_ENT 00031433) (USNM); 1 §, Mt Makiling, $14.13055^{\circ} \mathrm{N}, 121.2^{\circ} \mathrm{E}, 963 \mathrm{~m}$, no date provided, Baker leg. (UCR_ENT 00031434) (USNM).

\section{Other material}

PHILIPPINES: Luzon: 1 , , Albay Province, Mt Mayon, $16 \mathrm{~km} \mathrm{NW}$ of Lagaspi, $13.25666^{\circ} \mathrm{N}, 123.685^{\circ} \mathrm{E}$, 900 m, 4 May 1962, H.M. Torrevillas leg. (UCR_ENT 00073629) (BPBM); 1 + , Laguna, 4 km SE of Los Banos, Mt. Makiling, $14.14112^{\circ}$ N, $121.2097^{\circ}$ E, 8 Apr. 1977, L. Watrous leg. (UCR_ENT 00031438) (USNM); 1 ${ }^{2}$, same collection data as preceding but 9 Apr. 1977 (UCR_ENT 00031352) (USNM); 1 , Laguna Co., Los Banos, N Luzon, $14.17^{\circ} \mathrm{N}, 121.24416^{\circ} \mathrm{E}, 3$ Nov. 1914, G. Bottcher leg. (UCR_ENT 00069221) (BMNH); 3 $\widehat{\jmath}$, same collection data as for holotype (UCR_ENT 00031429-UCR_ENT 00031431) (USNM); 1 ㅇ, same collection data as preceding (UCR_ENT 00031437) (USNM); $1 \overline{+}, \mathrm{Mt}$ Maquiling, $14.12444^{\circ} \mathrm{N}, 121.22555^{\circ} \mathrm{E}, 18$ Jul. 1936, R.L. Usinger leg. (UCR_ENT 00046647) (CAS). 


\section{Description}

Male

Body LENGTH. Medium, total length $8.64 \mathrm{~mm}, \mathrm{SD} \pm 0.28$ (Appendix).

Coloration (Figs 14, 17). Yellowish-brown. Head yellowish to light brown. Scape, pedicel and distiflagellomere of antenna straw-colored, basiflagellomere basally brown, apically straw-colored. First segment of labium light brown, second segment straw-colored, third segment brown. Pronotum of thorax brown with straw-colored markings along ridges, scutellum basally brown, apically strawcolored including scutellar process, pleuron straw-colored with brown suffusion, sternum brown. Corium of hemelytron light brown to brown, membrane light brown to brown. Femora and tibiae of legs straw-colored with sub-basal and apical light brown annulations, tarsi and claws straw-colored. Abdomen dorsally yellowish orange, ventrally straw-colored with lateral brown suffusion, anterior half of connexivum dark brown, posterior half straw-colored, exposed part of pygophore straw-colored brown.

Vestiture. Sparsely setose. Head with widespread curved setae, ventral surface of postocular lobe with sparse, setigerous tubercles, with pair of long, straight setae on postocular lobe posterior to ocelli. Anterior lobe of thorax with irregular row of tuberculated, short, curved setae on lateral margins and fine, adpressed setae on dorsal surface, posterior lobe with short, curved, setigerous tubercles on humeral angle and glabrous on dorsal surface. Corium of hemelytron with short, curved setae. Legs with two rows of spines and setigerous tubercles, tibia with regular rows of tuberculated, stout, sharp setae. Connexival margin of abdomen with no prominent setae.

HEAD. Elongate conical; maxillary plate rounded apically; scape not reaching apex of clypeus; eye hemispherical in dorsal view.

Thorax. Antero-lateral paired projections subacute; surface of anterior lobe with low ridges; median pronotal depression not contiguous with transverse sulcus; paramedian carina weakly defined; anterior pronotal lobe longer and wider than posterior lobe, higher than posterior lobe in lateral view; parascutellar lobe rounded; scutellum rounded triangular, scutellar process long, apex subacute.

HemelYtron. Not attaining tip of abdomen.

Legs. Same as genus description.

ABDOMEN. Connexival margin slightly undulating, posterior margin not elevated.

GeNiTALIA. Transverse bridge of pygophore broad, margin of anterior opening angular, apodeme present, apical margin of posterior opening smooth; cup-like sclerite apically rounded with sclerotized paired latero-ventral slight protuberance; arms of basal plate converging; ductifer membranous; endosomal struts apically spatulate, basally divided into two plates; shape of dorsal phallothecal sclerite subacute with short, apical lobes and rounded lateral plates at apex.

\section{Female}

Similar to males except anterior pronotal lobe $(2.07 \mathrm{~mm}$ average $)$ narrower than posterior lobe $(2.60 \mathrm{~mm}$ average) and median pronotal depression contiguous with transverse sulcus.

\section{Ecology}

Nothing is known about the biology of this species. 


\section{Distribution}

This species is recorded from Luzon Island and Panay Island of the Philippines archipelago. Most specimens were collected from two localities: Mt Banahao and Mt Makiling in Luzon.

\section{Remarks}

This species differs from the co-occurring P. fuliginosa based on the diagnostic characters listed above and is placed within Physoderes based on the phylogenetic analysis conducted above.

Physoderes muluensis sp. nov.

urn:1sid:zoobank.org:act:E7064A8C-5E3B-44A5-A137-A17351E26074

Figs 8, 15, 19-20; Appendix

\section{Diagnosis}

This species is recognized among congeners by the males having the anterior pronotal lobe narrower than the posterior lobe, the median pronotal depression being contiguous with the transverse sulcus, the fore femur slightly incrassate and by the narrow transverse bridge of the pygophore. This species is distinguished from other species of Physoderes by the distinctly small size and the anterior pronotal lobe not being inflated in males.

\section{Etymology}

The name muluensis is a noun in apposition derived from the type locality Gunung Mulu National Park, Sarawak.

\section{Material examined}

\section{Holotype}

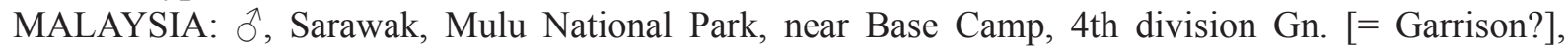
$3.97444^{\circ} \mathrm{N}, 114.93638^{\circ} \mathrm{E}, 100 \mathrm{~m}$, no date provided, collector unknown (UCR_ENT 00069405) $(\mathrm{BMNH})$.

\section{Paratypes}

MALAYSIA: Sarawak: $2{ }^{\AA} \partial$, Gunong Mulu National Park, $3.96638^{\circ} \mathrm{N}, 114.78305^{\circ} \mathrm{E}, 215 \mathrm{~m}$, May-Aug. 1978, P.M. Hammond and J.E. Marshall leg. (UCR_ENT 00069401, UCR_ENT 00069403) (BMNH); 2 우, same collection data as preceding (UCR_ENT 00069409, UCR_ENT 00069410) (BMNH); 1 क, Mulu National Park, near Base Camp, 4th division Gn. [= Garrison?], 3.97444 ${ }^{\circ} \mathrm{N}, 114.93638^{\circ} \mathrm{E}$, 100 m, May-Aug. 1978, P.M. Hammond and J.E. Marshall leg. (UCR_ENT 00069411) (BMNH); 1 \%, same collection data as preceding (UCR_ENT 00069400) (BMNH).

\section{Other material}

MALAYSIA: 2 juvs, Sarawak, Gunong Mulu National Park, $3.96638^{\circ} \mathrm{N}, 114.78305^{\circ} \mathrm{E}, 215 \mathrm{~m}$, MayAug. 1978, P.M. Hammond and J.E. Marshall leg. (UCR_ENT 00069402, UCR_ENT 00069404) (BMNH).

\section{Description}

\section{Male}

Body LENGTH. Small, total length $7.35 \mathrm{~mm}, \mathrm{SD} \pm 0.27$ (Appendix).

Coloration (Fig. 15). Brown. Head brown, lighter towards apex. Scape of antenna brown, pedicel brown with apex straw brown, basi- and distiflagellomeres basally brown and apically straw brown or straw brown entirely. First segment of labium brown, second segment gradation from brown to straw-colored, 
third segment straw-colored. Pronotum of thorax brown, sometimes posterior pronotal lobe lighter brown, scutellum brown, pleuron brown, sternum brown. Corium of hemelytron brown, membrane brown. Fore femur of legs brown entirely or basally dark brown, fore tibia straw-colored, basally brown, tarsus and claws straw-colored, mid femur entirely brown or brown with basally straw brown coloration, mid tibia, tarsus and claws brown and straw-colored, hind femur brown and basally straw-colored or straw-colored with medial brown band, hind tibia brown and straw brown, tarsus and claws straw brown. Abdomen dorsally orange-yellow, ventrally brown, connexivum brown with posterior third light brown, exposed part of pygophore brown.

VestituRE. Sparsely setose. Head with some flat, curved setae or with widespread short, fine, adpressed setae, ventral surface of postocular lobe with sparse, setigerous tubercles, with pair of long, straight setae on postocular lobe posterior to ocelli. Anterior lobe of thorax with irregular row of tuberculated, short, curved setae on lateral margins and short, setigerous tubercles dispersed on dorsal surface, posterior lobe with only short, sparse setae. Corium of hemelytron with short, sparse, adpressed setae. Legs with two rows of spines and setigerous tubercles, tibia with a few prominent tuberculated, stout, sharp setae. Posterior margin of connexivum of abdomen with long, fine setae.

HEAD. Elongate conical; maxillary plate truncate apically; scape reaching apex of clypeus; eye hemispherical in dorsal view, less than $1 / 5$ length of head.

THORAX. Antero-lateral paired projections acute, diverging; surface of anterior lobe with low ridges; median pronotal depression contiguous with transverse sulcus; paramedian carina weakly defined; anterior pronotal lobe of equal length to and narrower than posterior lobe, level with posterior lobe in lateral view; parascutellar lobe rounded, skewed towards median; scutellum rounded triangular, scutellar process short, apex rounded or subacute.

Hemelytron. Not attaining tip of abdomen.

LEGS. Same as genus description.

AвDomen. Connexival margin slightly undulating, posterior margin not elevated.

Genitalia. Anterior margin of mediosternite 8 undulating, without medial apodeme; transverse bridge of pygophore broad, margin of anterior opening angular, apodeme present, apical margin of posterior opening with slight medial protuberance; cup-like sclerite apically rounded, with adjacent paired round protuberances; arms of basal plate parallel to each other; ductifer membranous; endosomal struts conical, subacute apex, divided into two arms basally; shape of dorsal phallothecal sclerite subacute with lateral broad, plate-like prolongations, broad plates angularly oriented towards basal plate.

Female

Similar in size and shape to males.

\section{Ecology}

According to labels, specimens were collected in alluvial forest litter from tropical forests. A few specimens were collected using pitfall traps. Specimens collected are often partially or entirely encrusted with debris.

\section{Distribution}

Only known from around the type locality. 


\section{Physoderes mysorensis sp. nov. urn:lsid:zoobank.org:act:BF5118FD-0E1D-403B-AAAA-DE0D038FD2EE}

Figs 8, 13, 15, 18-19; Appendix

\section{Diagnosis}

This species is recognized among species of Physoderes by the scape reaching the apex of the clypeus, the small eye, the antero-lateral projection of the anterior pronotal lobe being acute and oriented anteriorly, the anterior pronotal lobe being wide, wider than the posterior lobe in males, only slightly narrower than the posterior lobe in females, the rounded parascutellar lobe, the dark brown scutellum, the scutellar process being straw-colored, subacute and short, and the hemelytron attaining the tip of the abdomen. This species is most similar to $P$. anamalaiensis sp. nov. and can be differentiated by the larger size (10.69-10.96 mm), by having an apodeme on mediosclerite 8 , a broad transverse bridge of the pygophore, and the margin of the anterior opening of the pygophore rounded in lateral view and with a sclerotized, angular ductifer.

\section{Etymology}

The name mysorensis is a noun in apposition as a tribute to the type locality Mysore, Karnataka, India where three out of the six specimens examined here were collected.

\section{Material examined}

\section{Holotype}

INDIA: ${ }^{\lambda}$, Kerala, Trivandrum Co., Ponmudi Range, $8.78638^{\circ}$ N, $77.30361^{\circ} \mathrm{E}, 914 \mathrm{~m}$, no date provided, S. Nathan leg. (UCR_ENT 00068943) (AMNH).

\section{Paratypes}

INDIA: Kerala: 1 +, same collection data as for holotype (UCR_ENT 00068940) (AMNH); 1 , May 1971, S. Nathan leg. (UCR_ENT 00068944) (AMNH). - Karnataka: 1 ○,, Mysore Co., Agumbe Ghat, $14.49666^{\circ} \mathrm{N}, 75.0825^{\circ} \mathrm{E}, 610 \mathrm{~m}$, May 1974, S. Nathan leg. (UCR_ENT 00068945) (AMNH); 2 우으, same collection data as preceding (UCR_ENT 00068946, UCR_ENT 00047705) (AMNH).

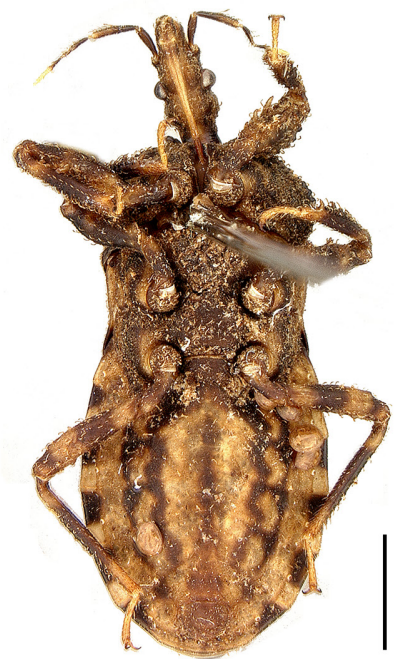

$P$. mysorensis sp. nov. Holotype UCR_ENT 00068944

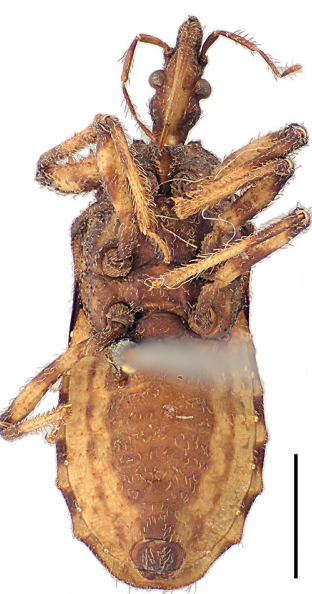

$P$. nigripennis sp. nov. Paratype UCR_ENT 00014055

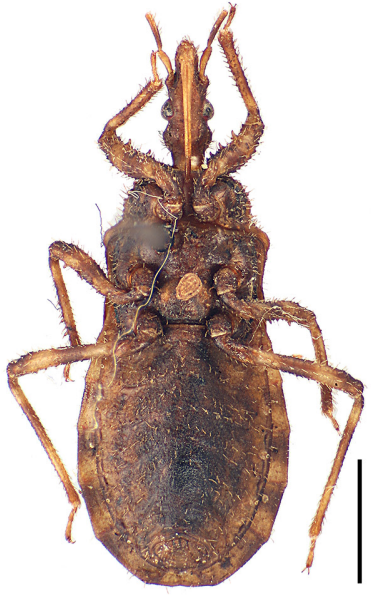

$P$. ractepilosa sp. nov. Holotype UCR_ENT 00014061

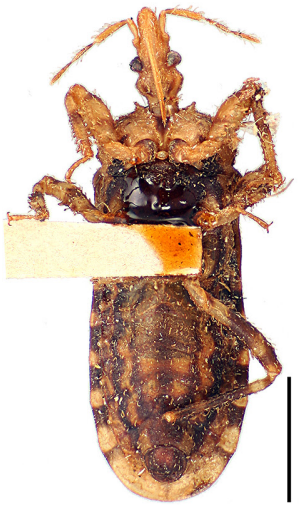

P. tricolor sp. nov. Holotype UCR_ENT 00030980

Fig. 18. Ventral habitus images for species of Physoderes Westwood, 1845 (partial). Scale bars $=2 \mathrm{~mm}$. 


\section{Description}

Male

Body LENGTH. Large, total length $10.82 \mathrm{~mm}, \mathrm{SD} \pm 0.14$ (Appendix).

Coloration (Figs 15, 18). Dark brown. Head dark brown. Scape, pedicel and basiflagellomere of antenna brown, distiflagellomere basally brown, apically straw-colored. First segment of labium basally brown, apically straw-colored, second segment straw-colored, third segment brown. Pronotum of thorax dark brown, parascutellar lobes lighter in color, scutellum dark brown, scutellar process straw-colored, pleuron dark brown with brown and straw-colored suffusion, sternum dark brown. Corium of hemelytron dark brown, membrane dark brown. Femur of legs straw-colored with medial and apical brown annulations, tibia brown with basal and apical straw-colored brown annulations, tarsus and claw straw-colored. Abdomen dorsally yellowish-orange, ventrally dark brown with suffusion of straw-color and brown, anterior half of connexivum dark brown, posterior half straw-colored, exposed part of pygophore brown.

VestiTURE. Sparsely setose. Head with widespread curved setae, ventral surface of postocular lobe with two rows of small, setigerous tubercles, with pair of long, straight setae on postocular lobe posterior to ocelli. Anterior lobe of thorax with irregular row of tuberculated, short, curved setae on lateral margins and short, setigerous tubercles dispersed on dorsal surface, posterior lobe with short, curved setae on humeral angle and sparsely distributed along dorsal surface. Corium of hemelytron with short, curved setae. Legs with two rows of spines and setigerous tubercles, tibia with regular rows of tuberculated, stout, sharp setae. Connexival margin of abdomen with no prominent setae.

HEAD. Elongate conical; maxillary plate rounded apically; scape reaching apex of clypeus; eye hemispherical in dorsal view, less than $1 / 5$ length of head; height of anteocular lobe level with postocular lobe.

THORAX. Antero-lateral paired projections acute; surface of anterior lobe with low ridges; median pronotal depression not contiguous with transverse sulcus; paramedian carina weakly defined; anterior pronotal lobe longer and wider than posterior lobe, higher than posterior lobe in lateral view; parascutellar lobe rounded; scutellum rounded triangular, scutellar process short, apex subacute; mesosternite with median irregular tuberculated protrusion between fore and mid coxae.

Hemelytron. Attaining tip of abdomen.

LEGS. Same as genus description.

АвDomen. Connexival margin slightly undulating, posterior margin not elevated.

GENITALIA. Anterior margin of mediosternite 8 undulating, with medial apodeme; transverse bridge of pygophore broad, margin of anterior opening rounded, apodeme present, apical margin of posterior opening smooth; cup-like sclerite apically rounded and rim ventrally sclerotized; arms of basal plate converging; ductifer with sclerotized angular ring; endosomal struts conical, with subacute apex, divided into two arms basally; shape of dorsal phallothecal sclerite subacute with lateral broad, platelike prolongations, with short, rounded lateral plates.

\section{Female}

Similar to males except anterior pronotal lobe slightly narrower than posterior lobe and median pronotal depression contiguous with transverse sulcus.

\section{Ecology}

Nothing is known about the biology of this species. 


\section{Distribution}

This species is known from two localities in Southwestern India: Agumbe Ghat, Mysore District, Karnataka and Ponmudi Range, Trivandrum District, Kerala.

\section{Remarks}

This species possesses the enlarged anterior pronotal lobe characteristic of Physoderes, along with the associated pronotal modifications, and is thus placed in this genus. The females possess an enlarged anterior pronotal lobe, although not as exaggerated as that of the males, which is quite unique. It is most likely to be closely related to the other Physoderes species native to India, $P$. anamalaiensis sp. nov. described above.

\section{Physoderes nigripennis sp. nov. urn:1sid:zoobank.org:act:0B62A6F5-805D-41F6-AC29-EB6DDE0144C8}

Figs 8, 15, 18-20; Appendix

\section{Diagnosis}

This species is recognized among congeners by the elongate conical head, which is densely covered in fine, curved setae, the scape reaching the apex of the clypeus, the eye being distinctly projecting, the antero-lateral pronotal projection being truncate, the anterior pronotal lobe distinctly narrower than the posterior lobe and covered with fine, curved setae along its ridges, the parascutellar lobe rounded and skewed towards median, the apex of the scutellar process straw-colored, the costal margin of the hemelytron black, the connexivum undulating with the posterior margin slightly elevated and beset with short, curved setae, the arms of the basal plate of the articulatory apparatus of the male genitalia being curved and the dorsal phallothecal sclerite being subacute, with lateral rounded plates extending to the lateral surface.

\section{Etymology}

The name nigripennis is after the Latin adjective "nigripennis", meaning with black wings or feathers, to describe the overall black coloration of the hemelytron.

\section{Material examined}

\section{Holotype}

INDONESIA: ${ }^{\lambda}$, Sumatra, Sumatera Barat (West Sumatra), $0.74^{\circ} \mathrm{N}, 100.8^{\circ} \mathrm{E}$, no date provided, E. Jacobson leg. (UCR_ENT 00023968) (RMNH).

\section{Paratypes}

INDONESIA: Sumatra, Sumatera Barat (West Sumatra): 1 đ , Fort de Kock, $0.26694^{\circ} \mathrm{N}, 100.38333^{\circ} \mathrm{E}$, $920 \mathrm{~m}, 1925$, E. Jacobson leg. (UCR_ENT 00023962) (RMNH); $4 \hat{\jmath} \widehat{\partial}$, same collection data as preceding but 1926 (UCR_ENT 00023954-UCR_ENT 00023956, UCR_ENT 00014055) (RMNH); 1 ô, Fort de Kock (Bukittinggi), $0.3167^{\circ} \mathrm{N}, 100.3667^{\circ}$ E, 920 m, Nov. 1920, E. Jacobson leg. (UCR_ ENT 00068913) (AMNH).

\section{Other material}

INDONESIA: Sumatra, Sumatera Barat (West Sumatra): Fort de Kock, $0.26694^{\circ} \mathrm{N}, 100.38333^{\circ} \mathrm{E}$, $920 \mathrm{~m}, 1924$, E. Jacobson leg. (UCR_ENT 00023987) (RMNH); 2 + $q$, same collection data as preceding but 1926 (UCR_ENT 00023985, UCR_ENT 00023986) (RMNH); 1 + , same collection data as preceding but 1925 (UCR_ENT 00069414) (BMNH); $9 \hat{\delta} \hat{\partial}$, same collection data as precding (UCR_ENT 00023957-UCR_ENT 00023961, UCR_ENT 00023963-UCR_ENT 00023966) (RMNH); 8 우, same collection data as preceding (UCR_ENT 00023977-UCR_ENT 00023984) (RMNH); 


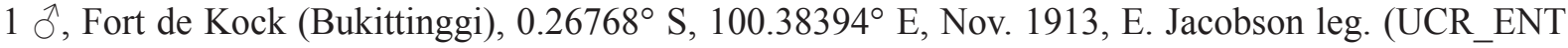

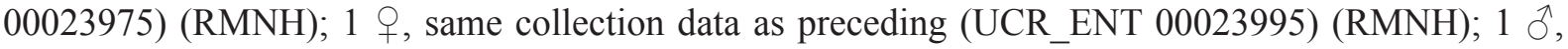
Gunning Singgalang, $0.39^{\circ} \mathrm{S}, 100.33083^{\circ} \mathrm{E}, 1200 \mathrm{~m}, 1925$, E. Jacobson leg. (UCR_ENT 00023974) (RMNH); 1 , , Gunung Singgalang, 1000 m, 1925, E. Jacobson leg. (UCR_ENT 00023994) (RMNH);

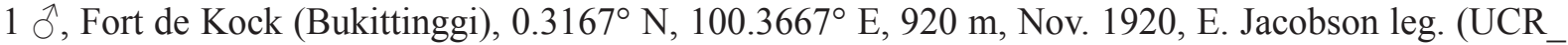
ENT 00068912) (AMNH); 2 + 9 , same collection data as preceding (UCR_ENT 00068914, UCR_ENT 00068915) (AMNH). - Sumatra, Riau Province: $6 \partial^{\lambda}, 0.74^{\circ} \mathrm{N}, 100.8^{\circ} \mathrm{E}$, no date provided, E. Jacobson leg. (UCR_ENT 00023967, UCR_ENT 00023969-UCR_ENT 00023973); 7 우, same collection data as preceding (UCR_ENT 00023988-UCR_ENT 00023993, UCR_ENT 00023996) (RMNH). - Sumatra, Sumatera Utara (North Sumatra): 1 đo, Lake Toba, $2.59194^{\circ} \mathrm{N}, 98.82805^{\circ} \mathrm{E}, 1167 \mathrm{~m}$, no date provided, B. Hagen leg. (UCR_ENT 00023976) (RMNH).

\section{Description}

\section{Male}

Body Length. Medium, total length $9.12 \mathrm{~mm}, \mathrm{SD} \pm 0.29$ (Appendix).

Coloration (Figs 15, 18). Brown and dark brown. Head brown with straw-colored setae. Antenna light brown. First segment of labium brown, second segment straw-colored, apically brown, third segment brown. Anterior lobe of pronotum dark brown with brown or light brown markings, posterior lobe brown, scutellum basally brown, apically straw-colored including scutellar process, pleuron brown, sternum brown. Corium of hemelytron reddish-brown with black costal margin, membrane brownishblack. Femora of legs straw-colored with medial and apical brown annulations, tibiae basally brown, apically straw-colored, tarsi and claws light brown. Abdomen dorsally yellowish-orange, ventrally light brown medially and straw-colored laterally with brown suffusion, anterior two-thirds of connexivum brownish-black, posterior third straw-colored, exposed part of pygophore dark brown.

VestituRE. Generally setose. Head with widespread curved setae, ventral surface of postocular lobe with sparse, setigerous tubercles, without pair of long, straight setae on postocular lobe posterior to ocelli. Anterior lobe of thorax with irregular row of tuberculated, short, curved setae on lateral margins and curved setae on anterior portion of dorsal surface, posterior lobe with widespread short, curved setae. Corium of hemelytron with short, curved setae. Legs with two rows of spines and setigerous tubercles, tibia with regular rows of tuberculated, stout, sharp setae. Posterior margin of connexivum of abdomen with short, curved setae.

HEAD. Elongate conical; maxillary plate truncate apically; scape reaching apex of clypeus; eye distinctly projecting in dorsal view, less than $1 / 5$ length of head.

THORAX. Antero-lateral paired projections truncate; surface of anterior lobe with raised ridges; median pronotal depression contiguous with transverse sulcus; paramedian carina strongly defined; anterior pronotal lobe shorter and narrower than posterior lobe, lower than posterior lobe in lateral view; parascutellar lobe rounded, skewed towards median; scutellum rounded triangular, scutellar process long, apex subacute.

Hemelytron. Reaching tip of abdomen.

Legs. Same as genus description.

ABDOMEN. Connexival margin undulating, posterior margin slightly elevated.

GenitaLiA. Transverse bridge of pygophore broad, margin of anterior opening angular, apodeme present, apical margin of posterior opening smooth; cup-like sclerite apically rounded, with adjacent paired 
round protuberances; arms of basal plate rounded; ductifer membranous; endosomal struts conical, with subacute apex, divided into two arms basally; shape of dorsal phallothecal sclerite subacute with lateral broad, plate-like prolongations, with short, rounded lateral plates at apex.

\section{Female}

Similar to male.

\section{Ecology}

This species was collected at relatively high altitudes of 920-1200 m.

\section{Distribution}

This species is found only in the central west region of Sumatra Island, where most specimens were collected from Bukit Tinggi, formerly Fort de Kock.

\section{Remarks}

This species is the most commonly collected on the island of Sumatra. It is placed within the Physoderes clade in the phylogenetic analysis above because of the shared synapomorphies of having the scape reaching the apex of the clypeus, rounded parascutellar lobes skewed toward the median and a membranous ductifer of the male genitalia.

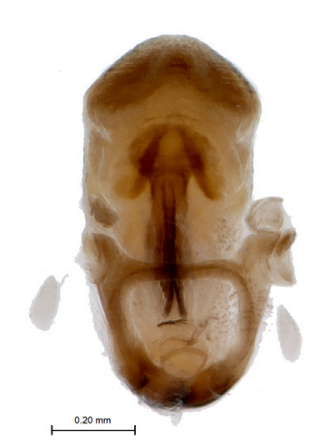

P. brevipennis sp. nov. Paratype UCR_ENT 00069376

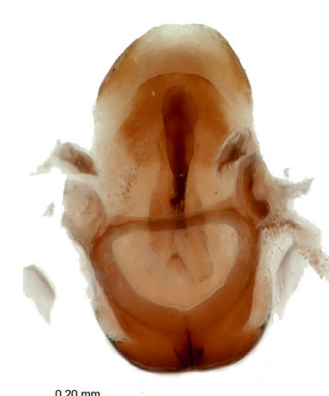

P. mysorensis sp. nov. Holotype UCR ENT 00068944
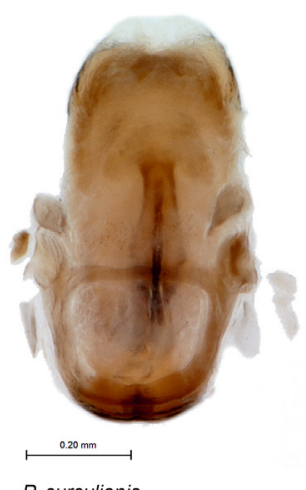

P. curculionis
UCR_ENT 00031401
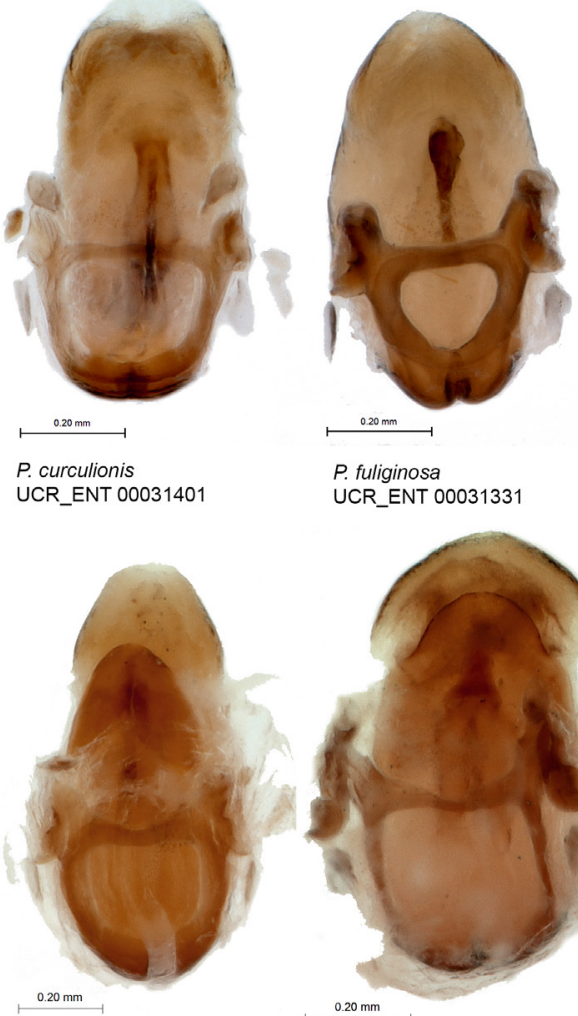

$P$. nigripennis sp. nov. UCR_ENT 00068913
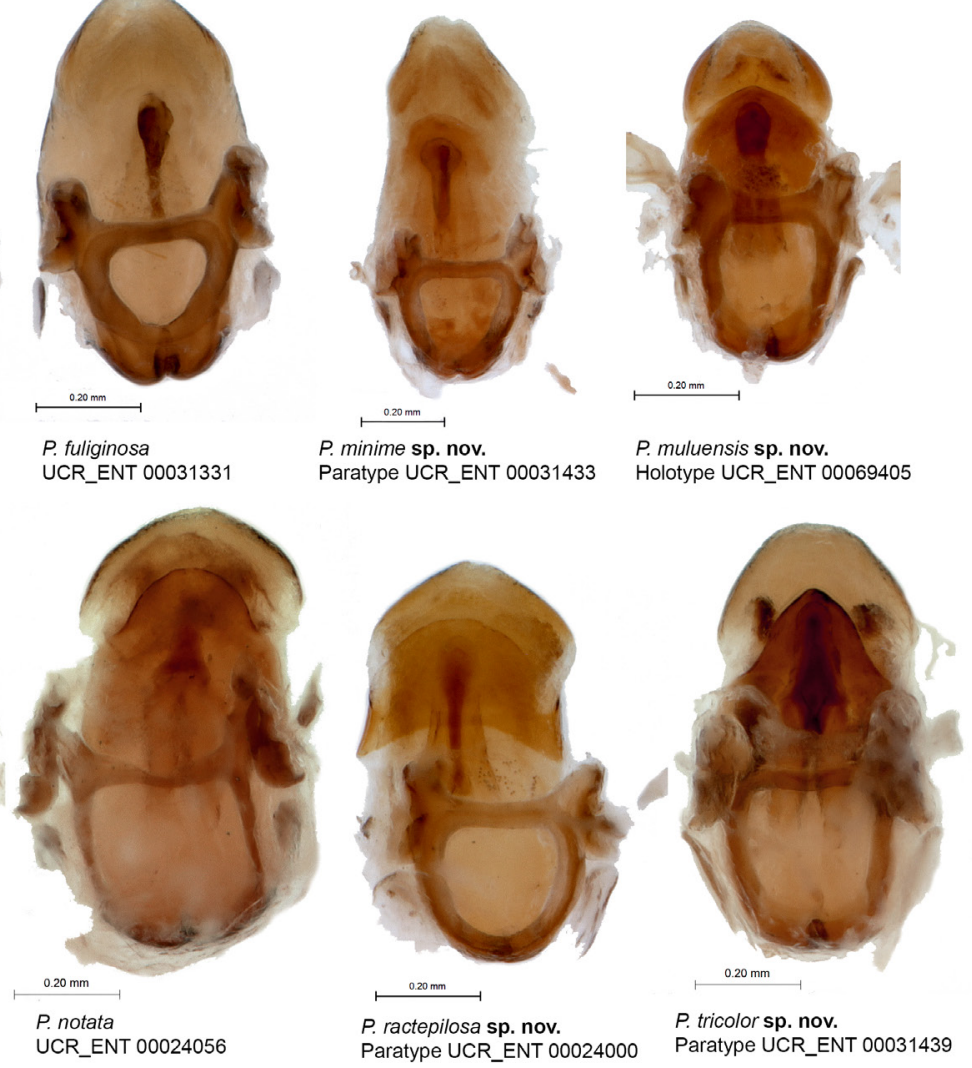

Fig. 19. Dorsal view of the phallus in species of Physoderes Westwood, 1845 (partial). 
Physoderes nigroalbus Breddin, 1903

Figs 15, 20; Appendix

Physoderes nigroalbus Breddin, 1903: 126.

\section{Diagnosis}

This species is recognized among species of Physoderes by the short and conical head, the scape not reaching the apex of the clypeus, the eye hemispherical and slightly flattened, the submedian pronotal carina strongly defined, the scutellum and scutellar process brown, the corium dark brown with the membranous portion basally dark brown including the external cell, and areas directly adjacent to the medial vein apical extension and first anal vein apex with remaining membrane off-white. This species is most similar to P. tricolor sp. nov., but can be differentiated from it by its size, coloration of the head, pronotum and scutellar process, and the shape of the eye.

\section{Material examined}

Lectotype (here designated)

INDONESIA: + , Sumatra, Tebing Tinggi, NE Sumatra, $3.31944^{\circ}$ N, 99.15222 ${ }^{\circ}$ E, 21 m, 10 Mar. 1884, Dr. Schultheiss leg. (UCR_ENT 00040566) (DEI).

\section{Redescription}

\section{Female}

Body Length. Medium, total length $9.74 \mathrm{~mm}$.

Coloration (Fig. 15). Brown. Head brown. Scape and pedicel of antenna light brown to brown, basiflagellomere brown, distiflagellomere basally brown, apically straw-colored. First segment of labium light brown, second segment straw-colored, apically brown, third segment brown. Anterior lobe of pronotum dark brown, posterior lobe brown, scutellum brown with dark brown scutellar process, pleuron brown with straw-colored suffusion, sternum brown to dark brown. Corium of hemelytron dark brown, membrane basally dark brown, apically off-white. Femur and tibia of legs straw-colored with basal, medial and apical brown annulations, tarsus and claw light brown. Abdomen dorsally yellowishorange, basally straw-colored with brown and dark brown patterns, anterior half of connexivum dark brown, posterior half straw-colored.

VestituRe. Sparsely setose. Head with widespread curved setae, ventral surface of postocular lobe with sparse, setigerous tubercles, without pair of long, straight setae on postocular lobe posterior to ocelli. Anterior lobe of thorax with irregular row of tuberculated, short, curved setae on lateral margins and short, setigerous tubercles dispersed on dorsal surface, posterior lobe with short, curved setae on humeral angle and sparsely distributed along dorsal surface. Corium of hemelytron with short, curved setae. Legs with two rows of spines and setigerous tubercles, tibia with regular rows of tuberculated, stout, sharp setae. Connexival margin of abdomen with no prominent setae.

HeAD. Short conical; maxillary plate rounded apically; scape not reaching apex of clypeus; eye hemispherical in dorsal view, less than $1 / 5$ length of head.

Thorax. Antero-lateral paired projections acute, diverging; surface of anterior lobe with low ridges; median pronotal depression contiguous with transverse sulcus; paramedian carina strongly defined; anterior pronotal lobe shorter and narrower than posterior lobe, lower than posterior lobe in lateral view; parascutellar lobe rounded, skewed towards median; scutellum rounded triangular, scutellar process long, apex subacute. 
Hemelytron. Attaining tip of abdomen.

Legs. Same as genus description.

AвDOMEn. Connexival margin slightly undulating, posterior margin not elevated.

\section{Male}

Unknown.

\section{Ecology}

Nothing is known about the biology of this species.

\section{Distribution}

This species is only known from the type locality in northeast Sumatra, Indonesia.

\section{Remarks}

This specimen was found by Stephan Blank at the DEI without a type label and labeled as Epirodera palliderostris [sic]. It is here interpreted as the type specimen or part of a syntype series that Breddin used to describe P. nigroalbus. Because Breddin did not label his types nor mention where they were deposited, this is currently the best assumption. Further evidence is given by the exact match in the locality information provided in Breddin's description and that on the specimen label, the lack of a range of measurements to suggest he examined more than one specimen, and matching description of the black and white hemelytron, measurement and sex. This specimen is thus designated as the lectotype for P. nigroalbus. No matching male specimens have been located and the redescription here is based on the single female lectotype specimen.

Physoderes notata Westwood, 1845

Figs 8, 13, 15-16, 19; Appendix

Physoderes notata Westwood, 1845: 68.

Physoderes brunneus Breddin, 1903: 127. New synonymy.

Physoderes buruensis Miller, 1954: 85, fig. 9. New synonymy,

Physoderes corporaali Miller, 1954: 88, fig. 12. New synonymy.

Physoderes flavipennis Miller, 1940: 556, fig. 92. New synonymy.

Epirodera notata - Westwood 1847: 248, pl. 18, fig. 5 (unsanctioned name change). Physoderes notata - Miller 1954: 82, fig. 8.

\section{Diagnosis}

This species is recognized among congeners by the short head, the scape shorter than the apex of the clypeus, the parascutellar lobe being rounded and skewed towards the median, the anterior pronotal lobe wider than the posterior lobe (males only), the median pronotal depression not contiguous with the transverse sulcus (males), the hemelytron reaching the tip of the abdomen, the hind wings being bright yellow and sometimes apically brown, the cup-like sclerite with rounded apex and adjacent paired protuberances, and the plate-like prolongations of the phallosoma with subacute apex and sharp lateral extensions. This species is similar to P. tricolor sp. nov. but can be differentiated from it based on the head and pronotal color patterns, hemelytron color, cup-like sclerite shape and the shape of the prolongations of the phallosoma. 


\section{Material examined}

Holotype

INDONESIA: ${ }^{\Uparrow}$, Java: $7.61444^{\circ} \mathrm{S}, 110.71222^{\circ} \mathrm{E}$, no date provided, unknown collector (UCR_ENT 00018526) (BMNH).

\section{Other material}

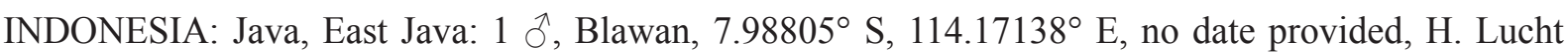
leg. (UCR_ENT 00024058) (RMNH); 4 우, Lawang, 7.77972 ${ }^{\circ} \mathrm{S}, 112.50611^{\circ} \mathrm{E}, 1496 \mathrm{~m}, 1907$, M. Buysman leg. (UCR_ENT 00024051-UCR_ENT 00024054) (RMNH); 3 우, Mount Tengger, $7.98857^{\circ} \mathrm{S}, 112.9166^{\circ} \mathrm{E}, 1219 \mathrm{~m}$, no date provided, H. Fruhstorfer leg., syntypes of Physoderes

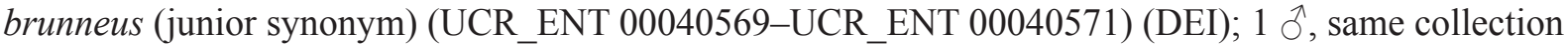
data as preceding, syntype of Physoderes brunneus (junior synonym) (UCR_ENT 00040572) (DEI); 1 , same collection data as preceding but 1890, syntype of Physoderes brunneus (junior synonym) (UCR_ENT 00040568) (DEI); 1 क , Nongkodjadjar (Nonkojajar), $7.91611^{\circ} \mathrm{S}, 112.8875^{\circ} \mathrm{E}, 846 \mathrm{~m}, 1911$, E. Jacobson leg. (UCR_ENT 00024055) (RMNH); 1 స,, same collection data as preceding (UCR_ENT 00024056) (RMNH). - Java, Central Java: 1 ${ }^{\top}$, Moeria Mts, Tjolo (Muria Mts), $6.61666^{\circ} \mathrm{S}, 110.9575^{\circ} \mathrm{E}$, 800 m, 20-24 Oct. 1939, M.A. Lieftinck leg. (UCR_ENT 00024060) (RMNH). - Java, West Java: 1 § , Preanger, Pelaburan (Pelabuhan), Jul. 1918 (unclear), J.B. Corporaal leg., holotype of Physoderes corporaali (junior synonym), MacGillavry Collection (ZMA.INS.834306) (ZMAN). - Maluku: $1 \hat{0}$, Buru Island, station 9, 1-19 Jul. 1921, L.J. Toxopeus leg., holotype of Physoderes buruensis (junior synonym), MacGillavry Collection (ZMA.INS.787862) (ZMAN). - Sulawesi, Sulawesi Utara (North Sulawesi): 1 을 Dumoga Bone National Park, Barney's Tree, $0.44972^{\circ} \mathrm{N}, 123.93305^{\circ} \mathrm{E}, 300 \mathrm{~m}, 13-22$ Nov. 1985, J. Krikken leg. (UCR_ENT 00024064) (RMNH); 3 우, Manado, $1.46361^{\circ}$ N, $124.31055^{\circ}$ E, Jun.-Oct. 1926, unknown collector (UCR_ENT 00046623, UCR_ENT 00046648, UCR_ENT 00046649) (CAS); 1 đo, Minahasa, $1^{\circ} \mathrm{N}, 124.58333^{\circ} \mathrm{E}, 550 \mathrm{~m}, 28 \mathrm{Jul} .1941$, F. Dupont leg. (UCR_ENT 00024062) (RMNH). - Sumatra, Sumatera Barat (West Sumatra): 3 우으, Baso, $0.27^{\circ} \mathrm{N}, 100.46333^{\circ} \mathrm{E}$, 800 m, Mar. 1926, E. Jacobson leg. (UCR_ENT 00024021-UCR_ENT 00024023); 1 §, same collection data as preceding (UCR_ENT 00024057) $(\mathrm{RMNH}) ; 1$ 을 Fort de Kock, $0.26694^{\circ} \mathrm{N}, 100.38333^{\circ} \mathrm{E}$, 920 m, 1926, E. Jacobson leg. (UCR_ENT 00024020) (RMNH); 1 q, Fort de Kock (Bukittinggi), $0.26768^{\circ} \mathrm{S}, 100.38394^{\circ}$ E, Nov. 1913, E. Jacobson leg. (UCR_ENT 00024019) (RMNH); 1 q, same collection data as preceding but Oct. 1913 (UCR_ENT 00014056) (RMNH); 1 đै, Gunning Singgalang, $0.39^{\circ} \mathrm{N}, 100.33083^{\circ} \mathrm{E}, 1200 \mathrm{~m}, 1925$, E. Jacobson leg. (UCR_ENT 00024026) (RMNH). - Sumatra, Sumatera Selatan (South Sumatra): 1 \&, SW Lampong District, Mt Tanggamoes, 5.41666 $\mathrm{S}, 104.7^{\circ} \mathrm{E}$, 700 m, Dec. 1939, M.A. Lieftinck leg. (UCR_ENT 00024025) (RMNH); 1 क , same collection data as preceding but at $500 \mathrm{~m}$ (UCR_ENT 00024024) (RMNH). - Sumatra, Sumatera Utara (North Sumatra):

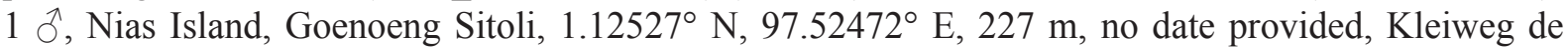
Zwaan leg. (UCR_ENT 00024027) (RMNH); 1 o, Padang Sidempuan, $1.3725^{\circ} \mathrm{N}, 99.25527^{\circ} \mathrm{E}, 332 \mathrm{~m}$, no date provided, J.D. Pasteur leg. (UCR_ENT 00024059) (RMNH).

MALAYSIA: Selangor: 1 , Kepong, in forest, $3.2325^{\circ}$ N, $101.6275^{\circ}$ E, Aug. 1949 , collector unknown (UCR_ENT 00031389) (USNM). - Perak: 1 ㅇ, Jor Camp, 4.89972 ${ }^{\circ} \mathrm{N}, 100.79055^{\circ}$ E, $610 \mathrm{~m}, 21$ Aug. 1922, E. Seimund leg., holotype of Physoderes flavipennis (junior synonym) (UCR_ENT 00018519) (BMNH).

\section{Redescription}

Male

Body Length. Medium-large, total length $9.94 \mathrm{~mm}, \mathrm{SD} \pm 0.3$ (Appendix).

Coloration (Figs 15-16). Straw-colored and brown. Anteocular lobe of head straw-colored with brown suffusion, postocular lobe brown. Antenna straw-colored with brown suffusion. First segment 
of labium light brown to brown, second segment straw-colored, third segment brown. Pronotum of thorax dark brown with straw-colored markings along ridges, scutellum basally dark brown, apically straw-colored, pleuron straw-colored with brown and dark brown patterns, sternum dark brown. Corium of hemelytron light brown to brown, membrane dark brown. Femur of legs straw-colored with subbasal and apical brown annulations, tibia brown with straw-colored base, tarsus and claw straw-colored. Abdomen dorsally yellow, ventrally straw-colored with sub-lateral dark brown patterns, anterior half of connexivum dark brown, posterior half straw-colored, exposed part of pygophore straw-colored.

VestiTURE. Sparsely setose. Head with some curved setae and short, fine, adpressed setae, ventral surface of postocular lobe with sparse, setigerous tubercles, with pair of long, straight setae on postocular lobe posterior to ocelli. Anterior lobe of thorax with irregular row of tuberculated, short, curved setae on lateral margins and short, setigerous tubercles dispersed on dorsal surface, posterior lobe with only short, sparse setae. Corium of hemelytron with short, curved setae. Legs with two rows of spines and setigerous tubercles, tibia with regular rows of tuberculated, stout, sharp setae. Connexival margin of abdomen with no prominent setae.

HEAD. Elongate conical; maxillary plate rounded apically; scape not reaching apex of clypeus; eye hemispherical in dorsal view, less than $1 / 5$ length of head.

Thorax. Antero-lateral paired projections acute, diverging; surface of anterior lobe with low ridges; median pronotal depression not contiguous with transverse sulcus; paramedian carina weakly defined; anterior pronotal lobe equal in length to and wider than posterior lobe, higher than posterior lobe in lateral view; parascutellar lobe rounded, skewed towards median; scutellum rounded triangular, scutellar process long, apex subacute.

Hemelytron. Attaining tip of abdomen.

LEGS. Same as genus description.

AвDomen. Connexival margin slightly undulating, posterior margin not elevated.

GeNITALIA. Anterior margin of mediosternite 8 sharply emarginate, without medial apodeme; transverse bridge of pygophore broad, margin of anterior opening angular, apodeme present, apical margin of posterior opening smooth; cup-like sclerite apically rounded with adjacent paired round protuberances; arms of basal plate parallel to each other; ductifer membranous; endosomal struts with tapered apex and divided into two arms basally; shape of dorsal phallothecal sclerite subacute with lateral broad, platelike prolongations, broad plate with a subacute apex and sharp lateral extensions.

\section{Female}

Females have a narrower anterior pronotal lobe with median pronotal depression contiguous with transverse sulcus and anterior lobe lower than the posterior lobe.

\section{Ecology}

Not much is recorded about the biology of this species. One specimen was collected from under sheaths of bamboo (Poaceae), another one was collected from multi-storey evergreen forest using 'canopy trap fish'. This species has been collected from a range of mid-level elevations from 227 to $1496 \mathrm{~m}$.

\section{Distribution}

This species is relatively widespread and can be found on peninsular Malaysia and the islands of Sumatra, Java and Sulawesi. 


\section{Remarks}

Examination of the holotype of $P$. flavipennis and the syntypes of $P$. brunneus indicate that both represent females of $P$. notata that have the narrower anterior pronotal lobe. Similarly, the holotype of $P$. corporaali shares the same diagnostic characters and color patterns on the head and pronotum with $P$. notata. Although the holotype of $P$. buruensis has a darker pronotum, all other characters are consistent with those of $P$. notata. The difference in pronotal coloration is hence regarded here as a color variant of the species, possibly unique to the Buru island population. All four species are hereby synonymized under P. notata.

\section{Physoderes ractepilosa $\mathrm{sp}$. nov. urn:Isid:zoobank.org:act:DFE461F4-658E-45E9-879C-D4747C0D8675}

Figs 8, 15, 18-20; Appendix

\section{Diagnosis}

This species is recognized among species of Physoderes by the body being covered with long, erect setae, the head being elongate conical, the scape not reaching the apex of the clypeus, the anterior pronotal lobe being narrower than the posterior lobe, the anterior pronotal lobe with raised ridges and strongly defined submedian carina, the parascutellar lobe rounded, the scutellar process slender, the fore femur slender and only slightly incrassate, the short hemelytron not reaching the tip of the abdomen, the connexival margin undulating and the females with a wider connexivum than in males. Additional diagnostic features are found on the male genitalia: the cup-like sclerite with rounded apex and broad adjacent sclerotized rounded protuberances, the apical margin of the posterior opening of the pygophore with medial process, the arms of the basal plate curved to form a rounded foramen and the apex of the dorsal phallothecal sclerite subacute, with broad lateral prolongations that project angularly towards the apex of the phallosoma. This species most closely resembles $P$. fuliginosa, but can be differentiated from it by the long, erect setae, the shape of the pronotum, parascutellar lobe and connexivum, as well as the hemelytron length.

\section{Etymology}

The name ractepilosa is a noun in apposition to describe the erect setation throughout the body of this species.

\section{Material examined}

Holotype

INDONESIA: + , Sulawesi Tengah, Lore Lindu National Park, Marena Forest, $1.51666^{\circ} \mathrm{N}$, $120.18333^{\circ}$ E, 650 m, 14-17 Dec. 1985, J. Krikken leg. (UCR_ENT 00014061) (RMNH).

\section{Paratypes}

INDONESIA: Sulawesi Tengah (Central Sulawesi): 1 d , Lore Lindu National Park, Marena Forest, near river, $1.51666^{\circ} \mathrm{S}, 120.18333^{\circ} \mathrm{E}, 600 \mathrm{~m}, 14-17$ Dec. 1985, J. Krikken leg. (UCR ENT 00023400) $(\mathrm{RMNH}) ; 4$ 우, same collection data as preceding (UCR ENT 00023401-UCR ENT 00023404) (RMNH). - Sulawesi Utara (North Sulawesi): 1 j, Dumoga Bone National Park, Mt Mogogonipa, $0.45^{\circ} \mathrm{N}, 123.93305^{\circ} \mathrm{E}, 1000 \mathrm{~m}, 22-25$ Aug. 1985, J. Huijbregts leg. (UCR_ENT 00023999) (RMNH).

\section{Description}

\section{Female}

Body Length. Medium, total length $9.19 \mathrm{~mm}, \mathrm{SD} \pm 0.67$ (Appendix).

Coloration (Figs 15, 18). Brown. Head brown. Scape and pedicel of antenna straw-colored with brown suffusion, basiflagellomere brown, distiflagellomere basally brown, apically straw-colored. First and 


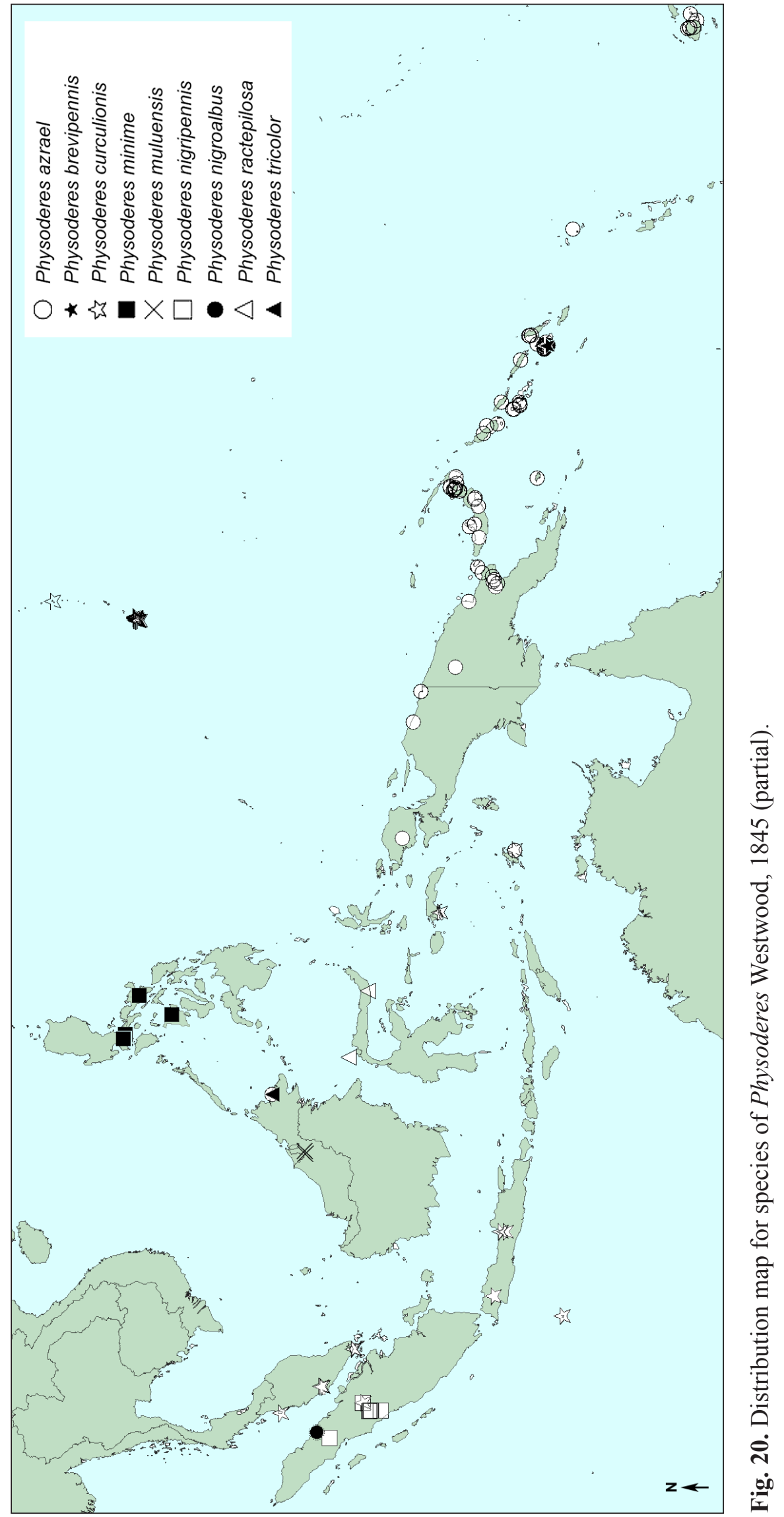


second segment of labium straw-colored, third segment brown. Anterior lobe of pronotum brown with straw-colored ridges, posterior lobe straw-colored, scutellum dark brown basally, straw-colored apically including scutellar apex, pleuron dark brown with straw-colored suffusion, sternum dark brown. Corium of hemelytron brown, membrane brown. Femora of legs straw-colored with medial and apical brown annulations, tibiae brown with basal and apical straw-colored brown annulations, tarsi and claws strawcolored. Abdomen dorsally yellow, ventrally brown with straw-colored suffusion laterally, anterior half of connexivum dark brown, posterior half straw-colored, exposed part of pygophore brown.

VeSTITURE. Generally densely setose. Head with widespread long, erect setae, ventral surface of postocular lobe with sparse, setigerous tubercles, with pair of long, straight setae on postocular lobe posterior to ocelli. Anterior lobe of thorax with irregular row of tuberculated, long, erect setae on lateral margins and on dorsal ridges, posterior lobe with long, erect setae on humeral angle and sparsely distributed along dorsal surface. Corium of hemelytron with long, erect setae. Legs with two rows of spines and setigerous tubercles, tibia with regular rows of tuberculated, stout, sharp setae. Posterior margin of connexivum of abdomen with long, fine setae.

HEAD. Elongate conical; maxillary plate truncate apically; scape not reaching apex of clypeus; eye hemispherical in dorsal view, less than $1 / 5$ length of head.

THORAX. Antero-lateral paired projections acute, diverging; surface of anterior lobe with raised ridges; median pronotal depression contiguous with transverse sulcus; paramedian carina strongly defined; anterior pronotal lobe shorter and narrower than posterior lobe, lower than posterior lobe in lateral view; parascutellar lobe rounded; scutellum rounded triangular, scutellar process long, apex subacute.

Hemelytron. Not reaching tip of abdomen.

LEGS. Same as genus description.

ABDomen. Elongate ovoid, with straight terminal margin; connexival margin undulating, posterior margin not elevated.

\section{Male}

Similar to females, but do not seem to have as many long, erect setae and connexivum not as wide.

Genitalia. Anterior margin of mediosternite 8 sharply emarginate, with medial apodeme; transverse bridge of pygophore broad, margin of anterior opening angular, apodeme present, apical margin of posterior opening with small medial process; cup-like sclerite apically rounded, with adjacent paired round protuberances; arms of basal plate rounded; ductifer membranous; apex of endosomal struts tapered and divided into two arms basally; shape of apex of dorsal phallothecal sclerite subacute with broad lateral prolongations that project angularly towards apex of phallosoma.

\section{Ecology}

Specimens were collected in multistorey evergreen forests using fish traps.

\section{Distribution}

This species is only known from the type locality in Central Sulawesi and another locality in northern Sulawesi.

\section{Remarks}

A female specimen is chosen as the holotype for this species because the long, erect setae covering the body are not as obvious in the two male specimens available. One of the males was collected from the 
same collecting event as the females and shares all other diagnostic characters. The unique setation may be sexually dimorphic. Additional male specimens will be required to determine this. The male was dissected and the genitalia described here show that this species is very different from any other species of Physoderes.

\section{Physoderes tricolor sp. nov. urn:Isid:zoobank.org:act:079BA84D-2C4E-444D-B57F-8555AD38438B}

Figs 8, 15, 18-20; Appendix

\section{Diagnosis}

This species is recognized among congeners by the short and conical head, the scape not reaching the apex of the clypeus, the eye distinctly projecting, the submedian pronotal carina weakly defined, the apex of the scutellar process straw-colored, the parascutellar lobe rounded and skewed towards median, the corium dark brown with the membranous portion basally dark brown, including the external cell, and areas directly adjacent to the medial vein apical extension and first anal vein apex with remaining membrane off-white and translucent, the abdominal dorsal surface dark brown, the apodeme of the anterior opening of the pygophore obsolete with the margin rounded, the cup-like sclerite with rounded apex and paired adjacent subacute protuberances and the dorsal phallothecal sclerite triangular in shape. This species is most similar to P. nigroalbus but can be differentiated from it by size, the coloration of the head, pronotum and scutellar process, and the shape of the eye.

\section{Etymology}

The name of this species is based on the Latin adjective "tricolor", meaning three-colored, to describe the three colors that are visible dorsally.

\section{Material examined}

\section{Holotype}

MALAYSIA: ${ }^{\AA}$, Sabah, Sandakan, $5.8333^{\circ} \mathrm{N}, 118.1167^{\circ} \mathrm{E}, 4 \mathrm{~m}$, no date provided, Baker leg. (UCR ENT 00030980) (USNM).

\section{Paratypes}

MALAYSIA: 1 $\hat{\text { a }}$, same collection data as for holotype (UCR_ENT 00031439) (USNM); 3 q $q$, same collection data as for holotype (UCR_ENT 00031440-UCR_ENT 00031442) (USNM).

\section{Description}

\section{Male}

Body Length. Medium, total length $8.66 \mathrm{~mm}, \mathrm{SD} \pm 0.16$ (Appendix).

Coloration(Figs 15, 18). Brown, brownish black and off-white. Head anteriorly straw-colored, posteriorly brown. Antenna straw-colored. First and second segment of labium straw-colored, third segment light brown. Anterior lobe of pronotum brown with straw-colored markings, posterior lobe brown, scutellum basally brown, apically straw-colored including scutellar process, pleuron straw-colored with brown patterns, sternum brown to dark brown. Corium of hemelytron dark brown, membrane basally dark brown, including the external cell, and areas directly adjacent to the medial vein apical extension and first anal vein apex with remaining membrane off-white and translucent. Femora and tibiae of legs straw-colored with medial and apical brown annulations, tarsi and claws light brown. Abdomen dorsally dark brown, ventrally straw-colored with brown and dark brown patterns, anterior half of connexivum dark brown, posterior half straw-colored, exposed part of pygophore dark brown. 
VestiTURE. Sparsely setose. Head with some curved setae and short, fine, adpressed setae, ventral surface of postocular lobe with sparse, setigerous tubercles, with pair of long, straight setae on postocular lobe posterior to ocelli. Anterior lobe of thorax with irregular row of tuberculated, short, curved setae on lateral margins and curved setae on the anterior portion of dorsal surface, posterior lobe with short, curved setae on humeral angle and sparsely distributed along dorsal surface. Corium of hemelytron with short, curved setae. Legs with two rows of spines and setigerous tubercles, tibia with regular rows of tuberculated, stout, sharp setae. Connexival margin of abdomen with a few clubbed setae on each segment, or connexival margin with no prominent setae.

HEAD. Short conical; maxillary plate rounded apically; scape not reaching apex of clypeus; eye distinctly projecting in dorsal view, less than $1 / 5$ length of head.

THORAX. Antero-lateral paired projections acute, diverging; surface of anterior lobe smooth, ridges almost obsolete; median pronotal depression not contiguous with transverse sulcus; paramedian carina weakly defined; anterior pronotal lobe shorter and slightly narrower than posterior lobe, anterior lobe level with posterior lobe in lateral view; parascutellar lobe rounded, skewed towards median; scutellum rounded triangular, scutellar process long, apex subacute.

HEMELYTRON. Reaching tip of abdomen.

LEGS. Same as genus description.

ABDomen. Connexival margin slightly undulating, posterior margin not elevated.

Genitalia. Anterior margin of mediosternite 8 undulating, without medial apodeme; transverse bridge of pygophore narrow, margin of anterior opening rounded, apodeme absent, apical margin of posterior opening smooth; cup-like sclerite apically rounded, with adjacent paired small subacute protuberances; arms of basal plate parallel to each other; ductifer membranous; endosomal struts tapered, with acute apex, divided into two arms basally; shape of dorsal phallothecal sclerite triangular with angular lateral prolongations.

\section{Female}

Similar to males except anterior pronotal lobe $(2.17 \mathrm{~mm}$ average $)$ distinctly narrower than posterior lobe (2.77 $\mathrm{mm}$ average) and median pronotal depression contiguous with transverse sulcus.

\section{Ecology}

Nothing is known about the biology of this species.

\section{Distribution}

This species is only known from the type locality of Sandakan, northeast Borneo.

\section{Remarks}

This species shares the general head and pronotal morphology of P. notata and is placed within the same clade as $P$. notata in the phylogenetic analysis above. 


\section{Revised Classification List}

Breviphysoderes gen. nov.

Type species: Physoderes mjoebergi Miller, 1940, by designation.

Breviphysoderes decora (Miller, 1940) comb. nov.

Physoderes decora Miller, 1940

Physoderes ostenta Miller, 1941, syn. nov.

Breviphysoderes fulvopicta gen. et sp. nov.

Breviphysoderes hobbyi (Miller, 1940) comb. nov.

Physoderes hobbyi Miller, 1940

Breviphysoderes mjoebergi (Miller, 1940) comb. nov.

Physoderes mjoebergi Miller, 1940

Physoderes dyak Miller, 1955b, syn. nov.

Breviphysoderes planicollis (Miller, 1940) comb. nov.

Physoderes planicollis Miller, 1940

Breviphysoderes shelfordi (Miller, 1940) comb. nov.

Physoderes shelfordi Miller, 1940

Breviphysoderes tenebrosa gen. et sp. nov.

Breviphysoderes vestita (Horváth, 1900), comb. nov. Epirodera vestita Horváth, 1900

Physoderes serraticollis Breddin, 1903, syn. nov.

Physoderes javanica Miller, 1940, syn. nov.

Physoderes rugosa Miller, 1954, syn. nov.

Physoderes vestita - Maldonado 1990

Macrophysoderes gen. nov.

Type species: Physoderes modesta Miller, 1940, by designation.

Macrophysoderes bengalensis (Distant, 1909) comb. nov.

Epirodera bengalensis Distant, 1909

Physoderes bengalensis - Maldonado 1990

Macrophysoderes cirripilosa gen. et sp. nov.

Macrophysoderes elongata gen. et sp. nov.

Macrophysoderes finisterre gen. et sp. nov.

Macrophysoderes grandis gen. et sp. nov.

Macrophysoderes histrionica (Miller, 1940) comb. nov.

Physoderes histrionica Miller, 1940

Macrophysoderes modesta (Miller, 1940) comb. nov.

Physoderes modesta Miller, 1940

Physoderes sibauana Miller, 1940, syn. nov.

Physoderes trusana Miller, 1940, syn. nov. 
Macrophysoderes monticola (Miller, 1940) comb. nov.

Physoderes monticola Miller, 1940

Physoderes dimidiata Miller, 1940, syn. nov.

Physoderes luiana Miller, 1940, syn. nov.

Nanophysoderes gen. nov.

Type species: Physoderes dentiscutum Bergroth, 1906, by designation.

Nanophysoderes dentiscutum (Bergroth, 1906) comb. nov.

Physoderes dentiscutum Bergroth, 1906

Paraphysoderes Villiers, 1962

Type species: Paraphysoderes crassa Villiers, 1962, by original designation.

Paraphysoderes crassa Villiers, 1962

Paraphysoderes peyrierasi Villiers, 1968

Paraphysoderes popeye sp. nov.

Physoderes Westwood, 1845

Type species: Physoderes notata Westwood, 1845, by monotypy.

Physoderes anamalaiensis sp. nov.

Physoderes azrael Kirkaldy, 1905

Physoderes brevipennis sp. nov.

Physoderes curculionis China, 1935

Physoderes insulanus Miller, 1940, syn. nov.

Physoderes patagiata Miller, 1941, syn. nov.

Physoderes minor Usinger, 1946, syn. nov.

Physoderes kalshoveni Miller, 1954, syn. nov.

Physoderes esakii Cao, Tomokuni \& Cai, 2011

Epirodera latithorax Esaki, 1931, nomen nudum

Physoderes latithorax - Maldonado 1990

Physoderes fuliginosa (Stål, 1870)

Epirodera fuliginosa Stål, 1870

Physoderes fuliginosa - Maldonado 1990

Physoderes manni Davranoglou, 2014

Physoderes mauriciensis (Villiers, 1964), comb. nov.

Epiroderoides mauriciensis Villiers, 1964

Physoderes minime sp. nov.

Physoderes muluensis sp. nov.

Physoderes mysorensis sp. nov. 
Physoderes nigripennis sp. nov.

Physoderes nigroalbus Breddin, 1903

Physoderes notata Westwood, 1845

Physoderes brunneus Breddin, 1903, syn. nov.

Physoderes flavipennis Miller, 1940, syn. nov.

Physoderes buruensis Miller, 1954, syn. nov.

Physoderes corporaali Miller, 1954, syn. nov.

Epirodera notata - Westwood 1847, unsanctioned name change

Physoderes notata - Miller 1954

Physoderes ractepilosa sp. nov.

Physoderes tricolor sp. nov.

\section{Incertae sedis}

Physoderes brancsiki Bergroth, 1906

Physoderes impexa (Distant, 1903)

Epirodera impexa Distant, 1903

Physoderes fuscus Breddin, 1903 (synonymized in Distant 1904)

Physoderes impexa - Izzard 1936

Physoderes pallidirostris (Stål, 1863)

Epirodera pallidirostris Stål, 1863

Physoderes pallidirostris - Maldonado 1990

\section{Discussion}

\section{Physoderinae phylogeny: implications for biogeography and character evolution}

Only three representatives of Physoderinae, two species of Physoderes and one of Breviphysoderes gen. nov., were previously included in a molecular phylogenetic analysis that also investigated divergence dates (Hwang \& Weirauch 2012). In that analysis, Physoderinae diverged around 45 Mya from the Neotropical Nalata clade, their closest relatives included in that analysis. Divergences within the genus Physoderes were hypothesized to be as recent as 5 Mya. Given these timelines, dispersal, not vicariance, is likely the best explanation for the occurrence of Physoderinae in Madagascar. The nonmonophyletic nature of the Madagascan Physoderinae indicates that the evolutionary history of this group in the Madagascan region cannot be explained by a single colonization event with subsequent radiation. However, the majority of Madagascan Physoderinae are part of a single evolutionary lineage, Clade A, indicating that the morphological diversity found amongst Madagascan Physoderinae may in fact be due to a radiation in response to different ecological factors on the island. The single Australasian species of Paraphysoderes may then represent an "out of Madagascar" dispersal event, while the single Mauritian species of Physoderes could represent a second colonization from the Madagascan region. A formal biogeographic analysis based on morphological and molecular data that also includes divergence dating analyses is now the essential next step to test this proposed scenario.

Our analysis partially supports the hypothesis that the Neotropical species of Physoderinae that appear to have retained a number of plesiomorphic features as summarized by Weirauch (2006), are the sister group of all remaining Physoderinae: Leptophysoderes and Cryptophysoderes do in fact form a clade and are sister to all Australasian, Oriental, and Madagascan Physoderinae, but the Afrotropical 
Porcelloderes is recovered as the sister group to all remaining Physoderinae. This somewhat puzzling result may in part be derived from the fact that pronotal structures are strongly represented in our morphological dataset and the pronotum is highly modified in the apterous Porcelloderes. This result is clearly in need of additional testing, preferably with the addition of molecular data, as is the apparent paraphyly of Leptophysoderes, which is likely due to the coding of two male (UCR_ENT 00014362, UCR_ENT 00014363) and two female (UCR_ENT 00014360, UCR_ENT 00014361) specimens that show significant sexual dimorphism.

Despite being riddled by homoplasy, an examination of morphological characters allows for several observations. As an example, the highly modified physoderines Tribelocephaloides, Henicocephaloides Villiers, 1962 and Mimoelasmodema, which are characterized by derived features including the ventral position of the eye and the lack of armature on the fore femur, are phylogenetically derived within their respective clades. In addition, unarmed and slender forelegs evolved independently from stout and heavily armed forelegs among the Neotropical clade (Leptophysoderes + Cryptophysoderes) and within a clade nested within the Madagascan Clade B (Befotaka Villiers, $1962+$ Rodepirea Villiers, $1962+$ Maroantsetrana Villiers, $1962+$ Henicocephaloides + Tribelocephaloides). We speculate that this might be in response to a shift in prey organism or a different predatory strategy.

\section{Comments on taxonomy}

Based on findings from our phylogenetic analysis that Physoderes is polyphyletic, we here redefine Physoderes and erect three new genera to accommodate the remaining species. We retain the name Physoderes for the clade that contains the type species of Physoderes, P. notata (Westwood, 1845), following the International Commission on Zoological Nomenclature. Redescriptions of Physoderes and Paraphysoderes and descriptions of the new genera are presented above. A summary of the taxonomic changes made in this publication and a list of new taxa described is also presented. A few species of Physoderes are placed as incertae sedis due to unknown locations of type specimens, leading to uncertainty in their identities. Attempts to locate these type specimens were unsuccessful, as the taxon authors did not specify depository sites and enquiries made to major European museums likely to house these specimens turned out negative.

Our revision of the Oriental and Australasian Physoderinae provides, for the first time, a comprehensive picture of the diversity patterns in these regions. Notably, the highest number of species is found on two islands, Borneo and New Guinea. Borneo had already been identified as a hotspot for physoderine species-level diversity by earlier workers (e.g., Miller 1940), but the addition of new species in the present study has emphasized this observation. Similarly, the addition of seven new species from New Guinea and the surrounding islands highlights the extreme diversity in this region. In contrast, the paucity of species described from the continental Oriental region may be an effect of poor sampling, a hypothesis that is supported by the fact that we discovered two new species from the Indian subcontinent for which we only examined a total of 42 specimens. Additional field work in the continental Oriental region will likely reveal additional undescribed diversity.

Distributional data on physoderine species in the Oriental and Australasian regions do not provide a cohesive pattern with regards to factors that determine species ranges. Some species are widely distributed across island archipelagos, with insignificant morphological variation (see Physoderes curculionis, $P$. fuliginosa, $P$. notata). Other species appear to be highly restricted to a small endemic range close to their type locality, despite adequate sampling in surrounding regions and the fact that these species are not isolated on an oceanic island (see Physoderes muluensis sp. nov., P. minime sp. nov.). Further investigations into the natural history of the various physoderine species will be needed to explain the diversity patterns observed in the Oriental and Australasian regions. 


\section{Acknowledgements}

This work was funded by NSF "Partnership in Enhancing Expertise in Taxonomy" (PEET) grant $\# 0933853$, awarded to C. Weirauch, who trained W.S. Hwang as a graduate student, and by MOE AcRF Tier 1 grant (R-159-000-002-112) funds to W.S. Hwang's current research. This work would not have been possible without strong support from the museum curatorial community: Stephan Blank (DEI), Mick Webb (BMNH), Eric Guilbert (MNHN), Tom Henry (USNM), Norman Penny (CAS), Toby Schuh and Christine Johnson (AMNH), Shepherd Myers (BPBM), Jerome Constant (ISNB), Yvonne van Nierop (RMNH), Dávid Rédei (HNHM) and Petr Kment (NMPC). Special thanks to Mick Webb and Eric Guilbert for hosting the museum visits by W.S. Hwang and allowing imaging of type specimens. Valuable information and images were also provided by Jean-Michel Berenger, Wanzhi Cai, Liangming Cao, Tadashi Ishikawa, James Koh, Eddy Lee Kam Peng, Yvonne van Nierop and Dávid Rédei. Many thanks to Stephanie Leon for assisting in the databasing and georeferencing of the specimens of Physoderinae, Kaleigh Russell for taking measurements for the Physoderinae Project and Rochelle Hoey Chamberlain for help with image editing. We are grateful for the thorough reading of the manuscript by the two anonymous reviewers.

\section{References}

Baňař P., Davranoglou L.R. \& Chlond D. 2016 A new species of Henicocephaloides from Eastern Madagascar (Hemiptera: Heteroptera: Reduviidae). Entomologica Americana 122 (1-2): 238-244. https://doi.org/10.1664/15-RA-050

Bergroth E. 1906. Neue Austro-malayische Hemiptera. Wiener Entomologische Zeitung 25: 12-16.

Breddin H.G. 1903. Über neue Paläotropische Reduviinen. Sitzungsberichte der Gesellschaft naturforschender Freunde zu Berlin 3: 111-129. Available from http://biodiversitylibrary.org/ page/7660662 [accessed 15 Jun. 2017].

Cao L., Tomokuni M. \& Cai W. 2011. Taxonomic notes on Physoderinae (Heteroptera: Reduviidae) from China. Zootaxa 2888: 23-30.

China W.E. 1935. Hemipterous predators of the weevils Cosmopolites and Odoiporus. Bulletin of Entomological Research 26: 497-498. http://doi.org/10.1017/S000748530003683X

Chlond D. 2011. A new species of the Madagascan genus Rodepirea Villiers, 1962 (Hemiptera: Heteroptera: Reduviidae: Physoderinae). Heteropterus Revista de Entomología 11 (2): 235-240.

Chlond D., Rédei D. \& Baňař P. 2016. A new species of the Madagascan genus Physoderoides (Hemiptera: Heteroptera: Reduviidae: Physoderinae). Entomologica Americana 122 (1-2): 245-250. https://doi.org/10.1664/15-RA-052

Dallwitz M.J., Paine T.A. \& Zurcher E.J. 1999. DELTA - Description Language for Taxonomy. DELTA editor, version 1.04. Available from http://delta-intkey.com/ [accessed 5 Jun. 2017].

Davis N.T. 1966. Contributions to morphology and phylogeny of Reduvioidea (Hemiptera-Heteroptera). 3. Male and female genitalia. Annals of the Entomological Society of America 59: 911-924. https://doi. org/10.1093/aesa/59.5.911

Davranoglou L.R. 2014. A new micropterous species of Physoderes from Fiji Islands (Hemiptera: Heteroptera: Reduviidae: Physoderinae). Zootaxa 3838 (2): 233-241. https://doi.org/10.11646/ zootaxa.3838.2.8 
Davranoglou L.R., Hwang W.S. \& Weirauch C. 2015. Neotropical Physoderinae revisited, with description of a new, sexually dimorphic species of Leptophysoderes Weirauch (Hemiptera: Reduviidae). Zootaxa 3963 (1): 89-99. https://doi.org/10.11646/zootaxa.3963.1.6

Distant W.L. 1903. Rhynchotal notes. XVIII. Heteroptera: Family Reduviidae. Annals and Magazine of Natural History (7) 12: 248-254. https://doi.org/10.1080/00222930308678849

Distant W.L. 1904. The Fauna of British India, including Ceylon and Burma in Rhynchota (Heteroptera). Vol. 2. Taylor and Francis, London.

Distant W.L. 1909. Rhynchota (Heteroptera) from British India. Annales de la Société entomologique de Belgique 53: 360-376.

Esaki T. 1931. Hemiptera-Heteroptera von der Insel Botol-Tobago (Kôtôsho), Süd Formosa. Bulletin of the Biogeographical Society of Japan 2: 209-220.

Forero D. \& Weirauch C. 2012. Comparative genitalic morphology in the New World resin bugs Apiomerini (Hemiptera, Heteroptera, Reduviidae, Harpactorinae). Deutsche Entomologische Zeitschrift 59 (1): 5-41. https://doi.org/10.1002/mmnd.201200001

Forthman M. \& Weirauch C. 2016. Phylogenetics and biogeography of the endemic Madagascan millipede assassin bugs (Hemiptera: Reduviidae: Ectrichodiinae). Molecular Phylogenetics \& Evolution 100: 219-233. https://doi.org/10.1016/j.ympev.2016.03.011

Forthman M. \& Weirauch C. 2017. Millipede assassins and allies (Heteroptera: Reduviidae: Ectrichodiinae, Tribelocephalinae): total evidence phylogeny, revised classification and evolution of sexual dimorphism. Systematic Entomology 42: 575-595. https://doi.org/10.1111/syen.12232

Goloboff P.A., Farris J.S. \& Nixon K.C. 2008. TNT, a free program for phylogenetic analysis. Cladistics 24: 774-786. https://doi.org/10.1111/j.1096-0031.2008.00217.x

Horváth G. 1900. Hemiptera. In: Semon R. 1894-1903 (ed.) Zoologische Forschungsreisen in Australien und dem Malayischen Archipiel. Denkschriften der medicinisch-naturwissenschaftlichen Gesellschaft zu Jena 5: 627-642.

Hwang W.S. \& Weirauch C. 2012. Evolutionary history of assassin bugs: insights from divergence dating and ancestral state reconstruction. PLoS One 7 (9): e45523. https://doi.org/10.1371/journal. pone. 0045523

Kirkaldy G.W. 1905. Memoirs on the Rhynchota collected by Dr. Arthur Willey, F.R.S., chiefly in Birara (New Britain) and Lifu. Transactions of the Entomological Society of London 3: 327-363. https://doi. org/10.1111/j.1365-2311.1905.tb00672.x

Latreille P.A. 1807. Genera Crustaceorum et Insectorum, secundum Ordinem Naturalem in Familias Disposita, Iconibus Exemplisque Plurimis Explicata. Vol. 3. Amand Koenig, Paris.

Lent H. \& Wygodzinsky P. 1979. Revision of the Triatominae (Hemiptera, Reduviidae), and their significance as vectors of Chagas' disease. Bulletin of the American Museum of Natural History 163: $125-520$.

Maddison W.P. \& Maddison D.R. 2011. Mesquite: a Modular System for Evolutionary Analysis, ver. 2.75. Available from https://mesquiteproject.wikispaces.com/ [accessed 5 Jun. 2017]. 
Maldonado J. 1990. Systematic catalogue of the Reduviidae of the World (Insecta: Heteroptera). Caribbean Journal of Science, Special Edition: 1-694.

Miller N.C.E. 1940. New genera and species of Malaysian Reduviidae. Journal of the Federated Malay States Museums 18: 415-599.

Miller N.C.E. 1941. New genera and species of Malaysian Reduviidae. Journal of the Federated Malay States Museums 18 (Suppl.): 776-803.

Miller N.C.E. 1954. New genera and species of Reduviidae from Indonesia and the description of a new subfamily (Hemiptera-Heteroptera). Tijdschrift voor Entomologie 97: 75-114.

Miller N.C.E. 1955a. Two new genera of Reduviidae (Hemiptera-Heteroptera) from Madagascar. Annalen des naturhistorischen Museums in Wien 60: 273-276.

Miller N.C.E. 1955b. New genera and species of Reduviidae (Hemiptera-Heteroptera) from Malaysia and the Philippine islands. Tijdschrift voor Entomologie 98: 57-76.

Nixon K. C. 1999-2002. WinClada ver. 1.0. Published by the author, Ithaca, NY, USA.

Rédei D. 2012. Porcelloderes impenetrabilis gen. \& sp. n. from Tanzania, an assassin bug camouflaging in the adult stage (Hemiptera: Heteroptera: Reduviidae: Physoderinae). African Invertebrates 53 (2): 601-613. https://doi.org/10.5733/afin.053.0208

Stål C. 1863. Formæ speciesque novae Reduviidum. Annales de la Société entomologique de France (4) 3: 25-58. Available from http://biodiversitylibrary.org/page/8256963 [accessed 15 Jun. 2017].

Stål C. 1870. Hemiptera Insularum Philippinarum. Bidrag till philippinska öarnes hemipter-fauna. Öfversigt av Kongliga Svenska Vetenskaps-Akademiens Förhandlingar 27: 607-776. Available from http://biodiversitylibrary.org/page/24634225 [accessed 15 Jun. 2017].

Usinger R.L. 1946. Insects of Guam - II. Heteroptera of Guam. Bernice P. Bishop Museum Bulletin 189: $11-103$.

Villiers A. 1962. Les reduviides de Madagascar, XXI. Reduviinae. Revue Française d'Entomologie 29: $241-253$.

Villiers A. 1964. Nouveaux hemiptères Reduviidae de l'Ile Maurice. Revue Française d'Entomologie 31: 307-314.

Villiers A. 1968. Insectes Hemipteres Reduviidae, XXVIII. Faune de Madagascar 28: 74-97.

Weirauch C. 2006. New genus and species of Physoderinae (Heteroptera: Reduviidae) from the New World, with a revised diagnosis of Physoderinae Miller. American Museum Novitates 3510: 1-9.

Weirauch C., Bérenger J.M., Berniker L., Forero D., Forthman M., Frankenberg S., Freedman A., Gordon E., Hoey-Chamberlain R., Hwang W.S., Marshall S.A., Michael A., Paiero S.M., Udah O., Watson W., Yeo M., Zhang G. \& Zhang J. 2014. An illustrated identification key to assassin bug subfamilies and tribes (Hemiptera: Reduviidae). Canadian Journal of Arthropod Identification 26: 1-115. https://doi. org/10.3752/cjai.2014.26

Westwood J.O. 1845. Descriptions of two new exotic Hemiptera in the cabinet of the British Museum. Journal of Proceedings of the Entomological Society of London 4: 115-116. 
Westwood J.O. 1847. Descriptions of various exotic heteropterous Hemiptera. Transactions of the Entomological Society of London 4 (4): 243-249. https://doi.org/10.1111/j.1365-2311.1847.tb01362.x

Wygodzinsky P. \& Maldonado Capriles J. 1972. Description of the first genus of Physoderine assassin bugs (Reduviidae, Hemiptera) from the New World. American Museum Novitates 2504: 1-7.

Manuscript received: 29 March 2016

Manuscript accepted: 21 October 2016

Published on: 3 August 2017

Subject editor: Gavin Broad

Desk editor: Danny Eibye-Jacobsen

Printed versions of all papers are also deposited in the libraries of the institutes that are members of the EJT consortium: Muséum national d'Histoire naturelle, Paris, France; Botanic Garden Meise, Belgium; Royal Museum for Central Africa, Tervuren, Belgium; Natural History Museum, London, United Kingdom; Royal Belgian Institute of Natural Sciences, Brussels, Belgium; Natural History Museum of Denmark, Copenhagen, Denmark; Naturalis Biodiversity Center, Leiden, the Netherlands; Museo Nacional de Ciencias Naturales-CSIC, Madrid, Spain; Real Jardín Botánico de Madrid CSIC, Spain. 


\section{Appendix}

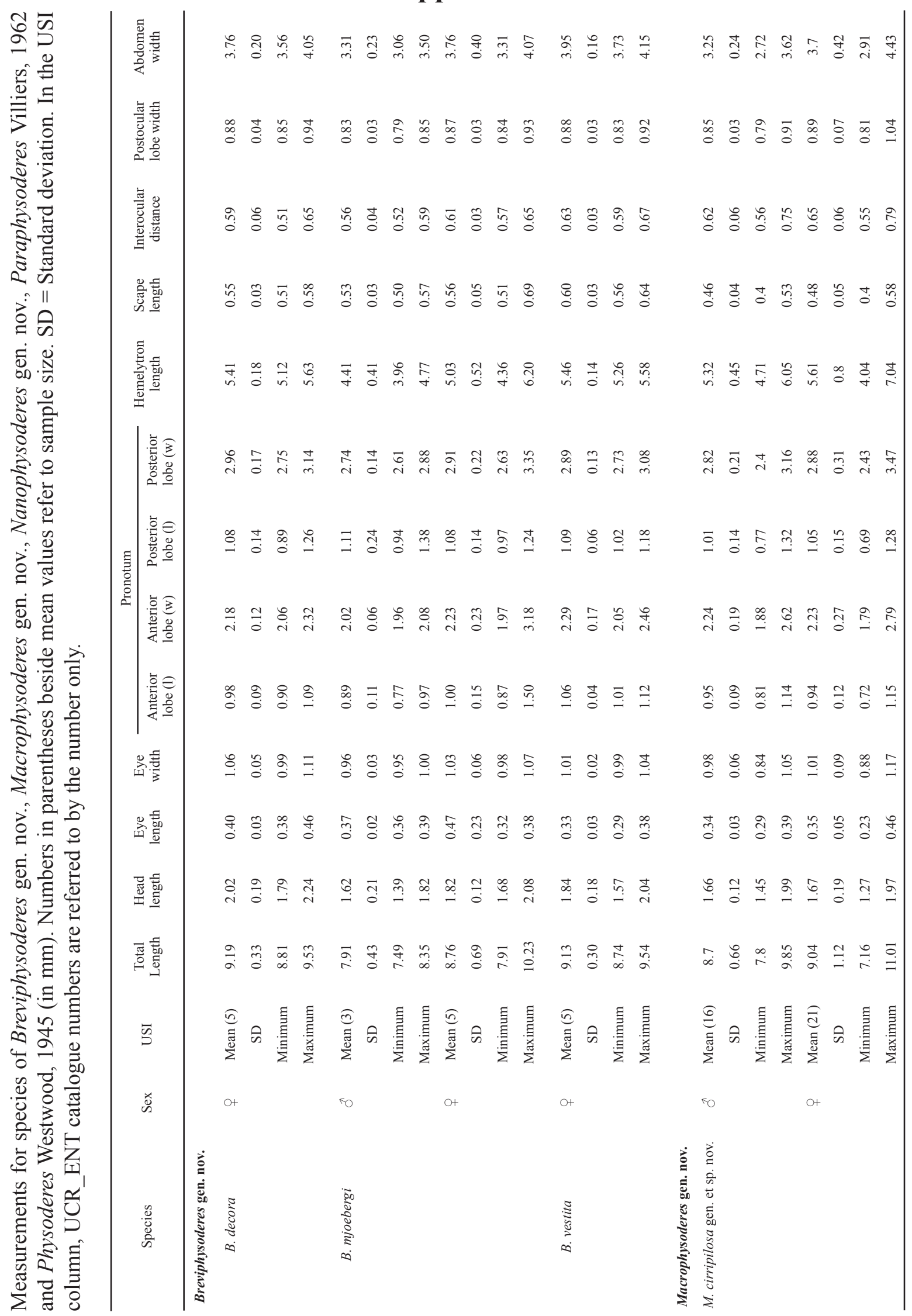




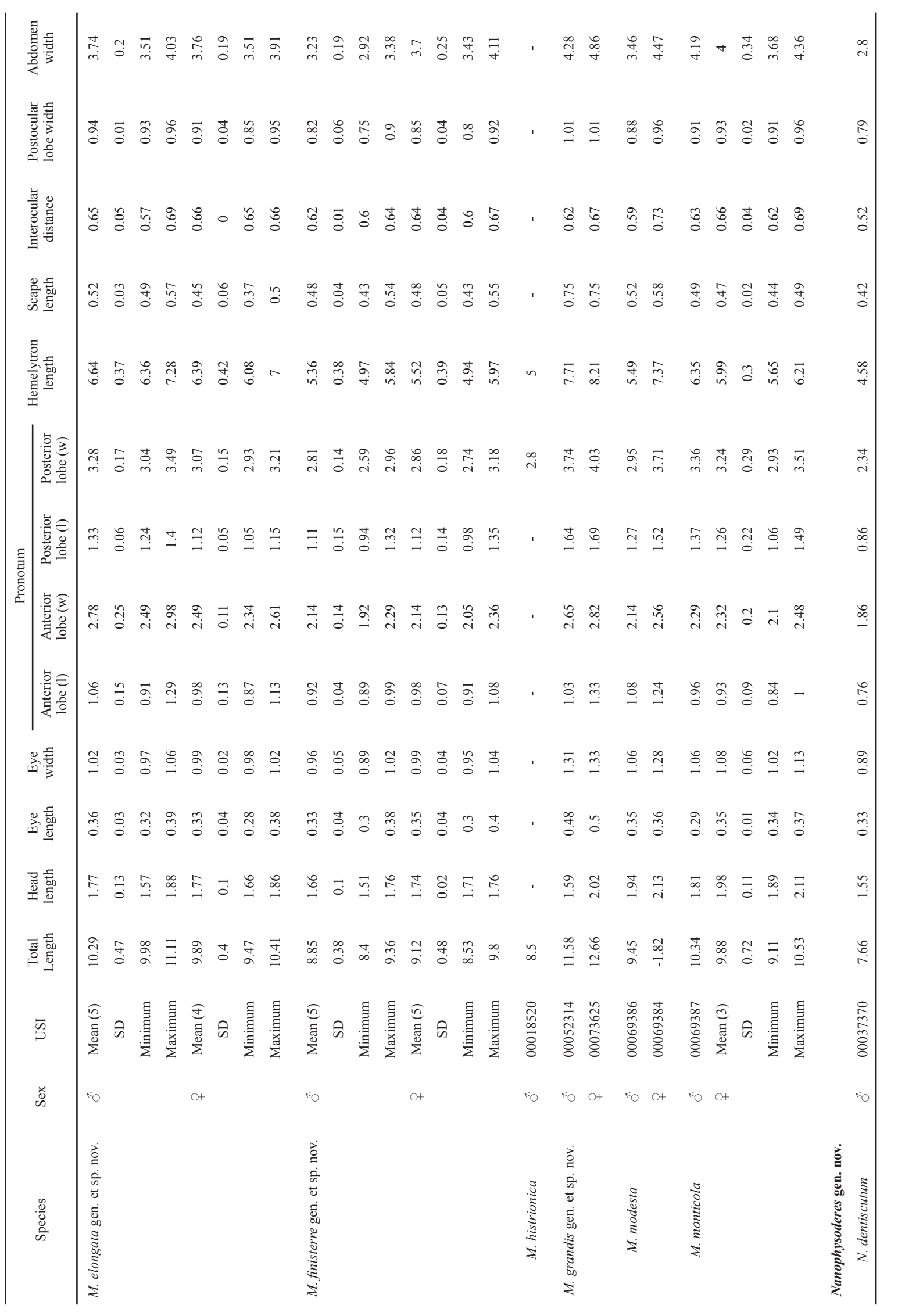




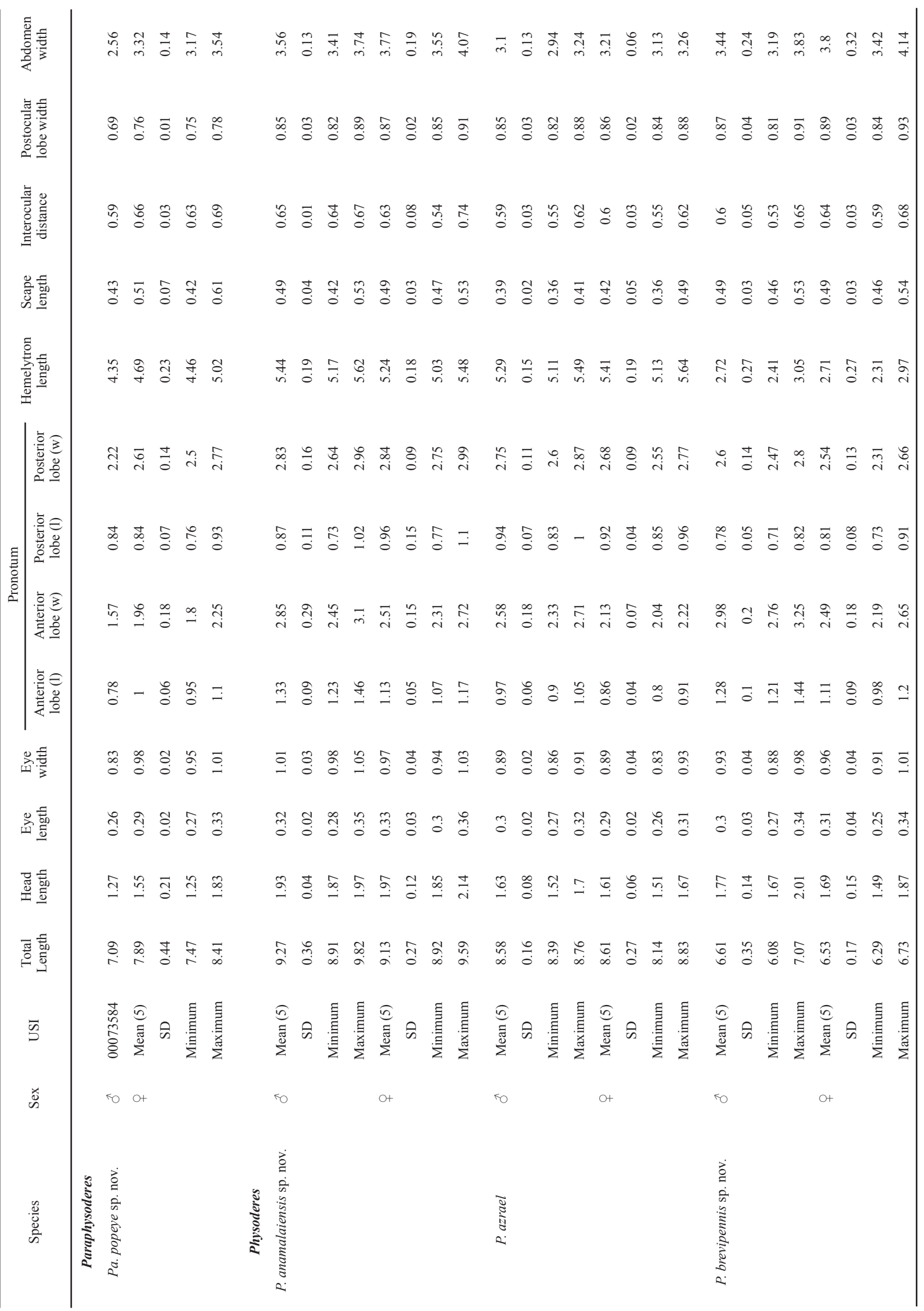




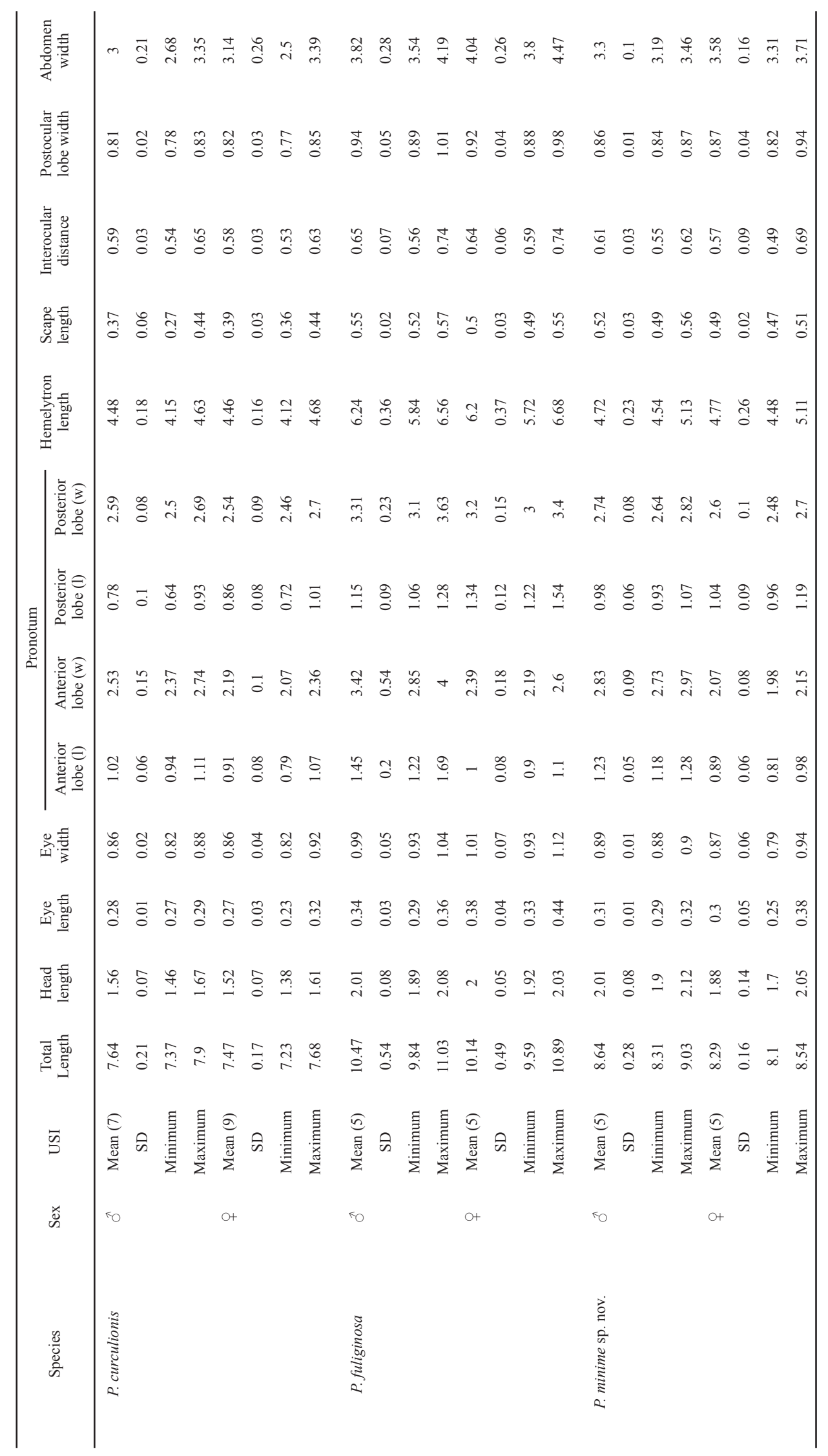




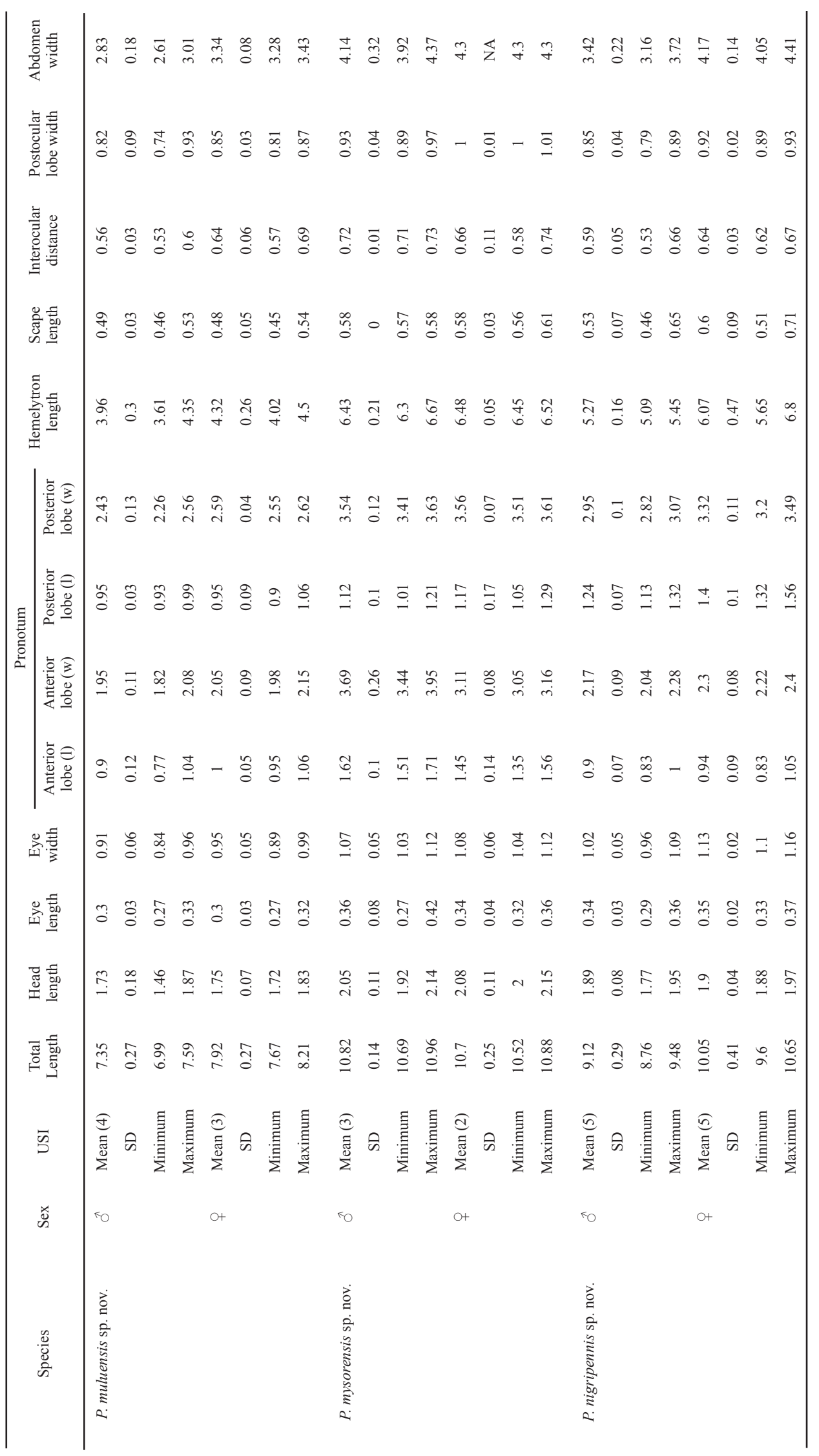




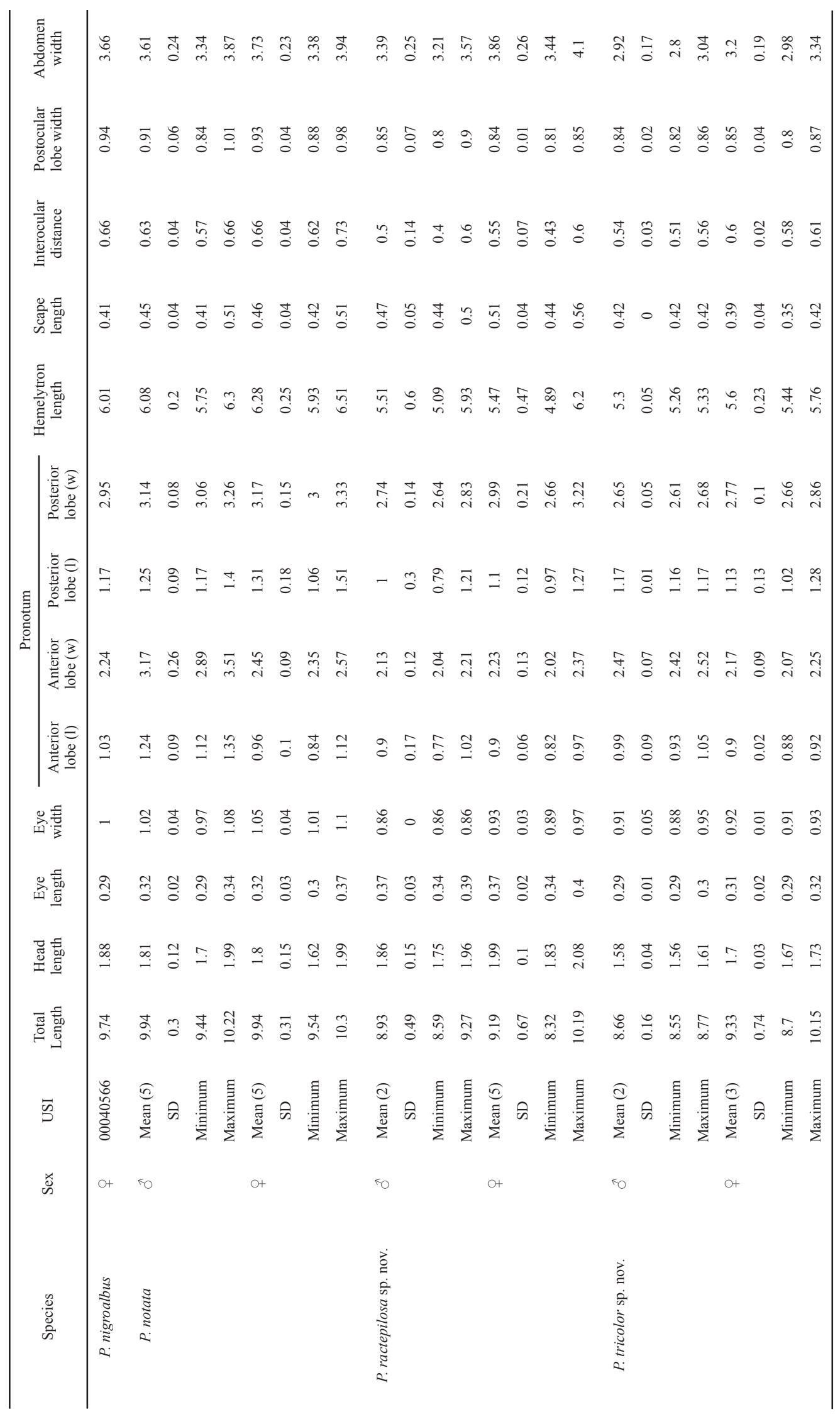

